\title{
CORREIOS, LOGÍSTICA E USO DO TERRITÓRIO: \\ O SERVIÇO DE ENCOMENDA EXPRESSA NO BRASIL
}

\author{
Versão corrigida
}

São Paulo 
IGOR VENCESLAU

\title{
CORREIOS, LOGÍSTICA E USO DO TERRITÓRIO:
}

\section{O SERVIÇO DE ENCOMENDA EXPRESSA NO BRASIL}

\author{
Versão corrigida
}

Dissertação apresentada ao Programa de PósGraduação em Geografia Humana do Departamento de Geografia da Faculdade de Filosofia, Letras e Ciências Humanas da Universidade de São Paulo, para obtenção do título de Mestre em Geografia Humana.

De acordo,

Profa. Dra. Mónica Arroyo

Orientadora

São Paulo 
Autorizo a reprodução e divulgação total ou parcial deste trabalho, por qualquer meio convencional ou eletrônico, para fins de estudo e pesquisa, desde que citada a fonte.

Catalogação na Publicação

Serviço de Biblioteca e Documentação

Faculdade de Filosofia, Letras e Ciências Humanas da Universidade de São Paulo

Venceslau, Igor

Correios, logística e uso do território: o serviço

C

de encomenda expressa no Brasil / Igor Venceslau ;

orientadora Mónica Arroyo. - São Paulo, 2016.

$250 \mathrm{f}$.

Dissertação (Mestrado)- Faculdade de Filosofia, Letras e Ciências Humanas da Universidade de São

Paulo. Departamento de Geografia. Área de concentração: Geografia Humana.

1. Uso do território. 2. Informação. 3. Redes. 4 Logística. 5. Correios. I. Arroyo, Mónica, orient. II. Título. 
Nome: VENCESLAU, Igor.

Título: Correios, logística e uso do território: o serviço de encomenda expressa no Brasil.

Dissertação apresentada ao Programa de PósGraduação em Geografia Humana do Departamento de Geografia da Faculdade de Filosofia, Letras e Ciências Humanas da Universidade de São Paulo, para obtenção do título de Mestre em Geografia Humana.

Aprovado em:

\section{Banca Examinadora}

Prof. Dr. Instituição:

Julgamento: Assinatura:

Prof. Dr. Instituição:

Julgamento: Assinatura:

Prof. Dr. Instituição:

Julgamento: Assinatura: 
À minha mãe e ao meu pai, uma carta sobre um patrimônio do Brasil 


\section{AGRADECIMENTOS}

À minha mãe Helena e ao meu pai Rodolfo, a quem devo o estímulo aos estudos e o interesse pela Geografia. Esta pesquisa não teria sido realizada sem seu apoio e dedicação ininterrupta ao longo desses três anos, desde que deixei a Bahia para realizar o curso de mestrado até os momentos finais.

À Profa. Dra. Mónica Arroyo, que além de orientadora e fonte de inspiração, se tornou amiga de todas as horas. Compartilhamos muito tempo em reuniões de orientações, estágio na disciplina de "Geografia Econômica I" na graduação, disciplina "Território e Circulação" na pós-graduação, organização de eventos, seminários, cafés, entre muitas outras oportunidades de aprendizado, que sublinho: a importância da política para a compreensão do espaço geográfico; a necessidade de contextualização das obras; o valor dos clássicos; e o rigor da pesquisa acadêmica. Certamente a Profa. Mónica não foi relevante apenas para a realização desta pesquisa, mas principalmente para a minha formação geral como geógrafo.

À Profa. Dra. Susan Roberts (University of Kentucky), pela supervisão durante o estágio de pesquisa realizado nos Estados Unidos, cuja contribuição foi fundamental para a realização de algumas etapas da investigação; mas também pela confiança em meu trabalho e pela notável disposição ao diálogo com os latino-americanos.

Ao Prof. Dr. Fábio Contel (FFLCH/USP), por quem cultivo imensa admiração e respeito, tendo desfrutado da oportunidade de aprender mais de Geografia nas aulas da disciplina "Espaço Geográfico, Urbanização e Finanças", no estágio de graduação na disciplina "Geografia da População" e no exame de qualificação de mestrado, além de eventos, seminários e colóquios.

Ao Prof. Dr. Ricardo Castillo (Unicamp) pelas contribuições no exame de qualificação, mas principalmente pelo exemplo de compromisso e dedicação à pesquisa e ao trabalho do geógrafo para as novas gerações.

Ao Prof. Dr. Antonio Carlos Robert Moraes (in memorian), nosso Tonico, que tão cedo nos deixou. Ele me proporcionou a honra de aprender em suas últimas aulas, na disciplina de pós-graduação "Formação territorial e teoria em geografia humana". Aos Profs. Drs. Vanderli Custódio (IEB/USP), Csaba Deák (FAU/USP) e Jean-Marc Besse (Université Paris 1 Pantheón-Sorbonne), pelas contribuições e diálogo interdisciplinar proporcionados pelos cursos realizados fora do Departamento de Geografia.

Aos Profs. Drs. Sandra Lencioni (FFLCH/USP), Daniel Huertas (Unifesp), Saint-Clair Trindade Jr. (UFPA), Hortênsia Castro (Universidad de Buenos Aires) e Verónica Hollman 
(Universidad de Buenos Aires) pelas preciosas contribuições durante seminários e cursos realizados no Departamento de Geografia da USP.

Aos Profs. Drs. Clarice Gonçalves e Gilmar Trindade (UESC), meus amigos e orientadores da graduação e especialização, exemplos de seriedade e comprometimento com a ciência geográfica, a quem devo parte significativa da minha formação inicial e as primeiras leituras da teoria do Prof. Milton Santos. A Clarice, em especial, devo também a orientação nos primeiros trabalhos sobre o correio, ainda na graduação.

Aos colegas do Laboratório de Geografia Política e Planejamento Territorial e Ambiental (LABOPLAN), pelas críticas e contribuições nos grupos de estudo e no cotidiano de trabalho: Paul Clívilan, Aline Oliveira, Victor Iamonti, Wagner Nabarro, Antônio Gomes, Rodolfo Finatti, Bruno Santos, Melissa Steda, Thiago Guerim, Fábio Brito, Lúcia Lirbório, André Pasti, Mariana Dell'Avanzi, Maíra Azevedo, Matheus Avelino, Carolina Israel, Caio Alves, Dhiego Medeiros, Jane Roberta e Flávio Vendrusculo. Sou grato também a Ana pela prontidão em colaborar nas atividades do laboratório.

Aos colegas e amigos da University of Kentucky: Nate Millington, Kenny Stancil, Christine Woodward e Eric Huntley pela recepção, companhia e auxílio durante o estágio de pesquisa nos EUA. A Patrick e a Ashton sou devedor pelas caronas e acomodações indispensáveis para o trabalho de campo na cidade de Louisville.

À professora Deborah Cowen, da University of Toronto, por ter me recebido em evento organizado naquela instituição.

Aos amigos do CRUSP: Fran Alavina, Alessandra Garcia, Simone Santos, Cláudia Tífaro, Milton Bortoleto, Ivan Rocha, Michell Tolentino, Eudes Leopoldo e Juliana Luquez, pela convivência e presença constante em todos os momentos (de solidão e de alegrias).

Aos meus tios Fátima e Onias, pelo acolhimento inicial em São Paulo.

À Empresa Brasileira de Correios e Telégrafos, sem a qual esta pesquisa teria sido inviabilizada, os seguintes agradecimentos: pelas informações concedidas e a disponibilidade de dados; pelo acesso às unidades da empresa - Administração Central, Diretoria Regional São Paulo Metropolitana, Centro de Tratamento de Encomendas Jaguaré, Museu dos Correios e Universidade Corporativa dos Correios; pela disponibilização de funcionários para acompanhamento nos trabalhos de campo.

Aos sujeitos entrevistados direta ou indiretamente nesta pesquisa, no Brasil e nos Estados Unidos, pelas preciosas informações concedidas: Maria Cleusa (CTE Jaguaré/Correios), Patrícia (GCCAP/Correios), Wagner (CTE Jaguaré/Correios), Jobson (CTE Jaguaré/Correios), Romulo Valle (Museu dos Correios), Elder Lopes (Administração 
Central/Correios), Paulo Roberto Lobo (Universidade Corporativa dos Correios), Clint Burelson (American Postal Workers Union), Erik Dunnigan (Kentucky Cabinet for Economic Development), Nancy Pope (National Postal Museum), Mary Ellen Wiederwohl (Louisville Forward) e Johnnie Edwards (UPS).

À Fundação de Amparo à Pesquisa do Estado de São Paulo (FAPESP), pelos recursos das bolsas de pesquisa no país (processo $n^{\circ}$ 2013/19277-2) e no exterior (processo $\mathrm{n}^{\circ}$ 2015/06152-2), sem os quais os resultados desta pesquisa dificilmente teriam sido alcançados. 
Levo o mundo e não vou lá

Levo o mundo e não vou

[...]

Leve o mundo que eu vou já

Leve o mundo que eu vou

E.C.T.

Compositores: Marisa Monte, Nando Reis e Carlinhos Brown Intérprete: Cássia Eller 


\section{RESUMO}

VENCESLAU, Igor. Correios, logística e uso do território: o serviço de encomenda expressa no Brasil. 2016. 250 f. Dissertação (Mestrado em Geografia Humana). Faculdade de Filosofia, Letras e Ciências Humanas, Universidade de São Paulo, São Paulo, 2016.

$\mathrm{O}$ volume de cartas e encomendas vem apresentando um crescimento vertiginoso nos últimos anos, contrariando as previsões sobre a perda de importância do correio com o advento da Internet. No Brasil, os serviços postais passaram por profundas transformações nas últimas décadas, com destaque para a criação do Serviço de Encomenda Expressa (SEDEX) pelos Correios, emblemático da aceleração na circulação de mensagens e mercadorias e do uso intensivo das tecnologias de informação no período atual. Esta pesquisa tem o objetivo de desvelar e analisar as estratégias de uso do território brasileiro pelos Correios para garantir maior racionalidade e velocidade aos serviços postais por meio da logística, compreendendo o papel atual da empresa na formação socioespacial brasileira, sob a tríade Estado-territóriomercado. Mediante revisão bibliográfica, análise de dados sobre os prazos de entrega, modais de transporte, localização de unidades operacionais dos Correios, origem e destino dos fluxos, etc., além de trabalhos de campo e entrevistas, foi possível identificar que o território brasileiro e sua rede de transporte é um elemento importante para entender a difusão dos serviços expressos no país. Desde a sua criação, o correio tem tido um papel relevante na integração territorial, cuja difusão acompanhou o processo de urbanização. Com a introdução da logística no correio, as etapas de coleta, tratamento, encaminhamento e entrega passaram a ser coordenadas sob uma mesma estratégia de circulação. Ainda assim, foi possível verificar uma diversidade de prazos de entrega no Brasil, pois a logística depende da materialidade de um território que é desigual. Dentre as estratégias de uso do território, a empresa se vale de operação em rede, da intermodalidade dos sistemas de transporte, da divisão políticoadministrativa vigente, das condições normativas nacionais e das tecnologias de informação disponíveis. Os resultados alcançados revelaram: a) a criação do SEDEX e sua sucessiva propagação é correspondente à difusão do meio técnico-científico-informacional no Brasil; b) o monopólio postal estatal é um constrangimento à ação das empresas multinacionais de correio (FedEx, DHL, UPS, etc.); c) os fluxos informacionais são indispensáveis para a circulação do correio, sobretudo na modalidade expressa; d) os serviços expressos fragmentam o objeto postal, levando a um processo concomitante de integração-diferenciação do território; e) o e-commerce impulsionou os serviços dos Correios e sua realização se ampara na logística postal; f) a topologia dos Correios se confunde com a rede urbana brasileira, comportando uma hierarquia com primazia de São Paulo, maior complexidade na Região Concentrada e profunda diferenciação regional; g) a topologia dos Correios reflete a divisão territorial do trabalho vigente; $h$ ) os fluxos postais no Brasil são predominantemente regionais. Por fim, a partir da instalação de fixos geográficos em todos os municípios, os Correios agem como um "braço logístico" do Estado, cujas ações garantem a execução de políticas públicas.

Palavras-chave: Uso do território; informação; redes; logística; Correios. 


\begin{abstract}
VENCESLAU, Igor. Correios, logistics and use of territory: the express mail service in Brazil. 2016. 250 f. Thesis (Master's Degree in Human Geography) - Faculdade de Filosofia, Letras e Ciências Humanas, Universidade de São Paulo, São Paulo, 2016.

The amount of letters and parcels has been presenting a vertiginous increase in the last years, on the contrary of the previsions about the decrease in the importance of the mail with the advent of Internet. In Brazil, the mail services underwent profound changes in the last decades, especially the creation of the express mail service (SEDEX) by the Brazilian post Correios, emblematic of acceleration in the circulation of messages and goods and the intense use of informational technologies in this period. This research aims to reveal and analyze the Correios' use of territory strategies in order to ensure greater rationality and velocity to the mail services using logistics, understanding the company's current role in the Brazilian sociospatial formation, under the triad State-territory-market. By means of bibliographical review, data analysis of delivery times, transportation, Correios' operational facilities location, origins and destinations of the flows, etc., as well as fieldworks and interviews, it was identified the territory and its transport network as a crucial element to understand the diffusion of the express mail services in the country. Since its creation, the mail has had a relevant role in the territorial integration, whose spread followed the urbanization process. With the insertion of the logistics in the mail, the stages of postage, separation, distribution and delivery were coordinated under a unique circulation strategy. Even so, it was possible to identify a large variety of delivery times in Brazil, due to logistics' dependency on the materiality of the territory, which is uneven. Amongst the use of territory strategies, the company adopts a network-based operation, an intermodal transport system, the current political-administrative division, the national normative conditions and the informational technology available. The results achieved reveal: a) the creation of SEDEX and its successive spread corresponds to the diffusion of a techno-scientific-informational milieu in Brazil; b) the State's postal monopoly deters the multinational postal companies' actions (FedEx, DHL, UPS, etc.); c) the informational flows are essential to the mail circulation, especially the express one; d) the express services fragment the postal object, leading to a concomitant process of integrationdifferentiation of the territory; e) the e-commerce boosted the Correios' services and its performance is based on the postal logistics; f) the Correios' topology is similar to the Brazilian urban system, showing a hierarchy with the primacy of São Paulo, greater complexity in the core region and extreme regional differentiation; g) the Correios' topology reflects the spatial division of labor; $h$ ) the postal flows in Brazil are predominantly regional. At last, since the establishment of facilities in all municipalities, Correios acts as a State's "logistics arm", with actions that allow public policies.
\end{abstract}

Keywords: Use of territory; information; networks; logistics; Correios. 


\section{LISTA DE DIAGRAMAS}

Diagrama 1 - Esquema topológico dos Correios no Brasil, 2016

\section{LISTA DE FIGURAS}

Figura 1 - Tempo de entrega de correspondências em Veneza a partir da Europa em 150024 Figura 2 - Tempo de entrega de correspondências em Veneza a partir da Europa entre 1686 e 1700

Figura 3 - Tempo de entrega de correspondências em Veneza a partir da Europa entre 1733

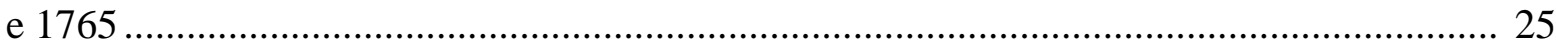

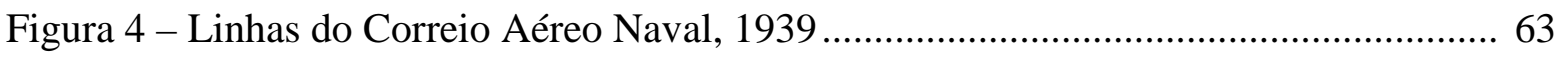

Figura 5 - Linhas do Correio Aéreo Militar, 1939 ............................................................ 63

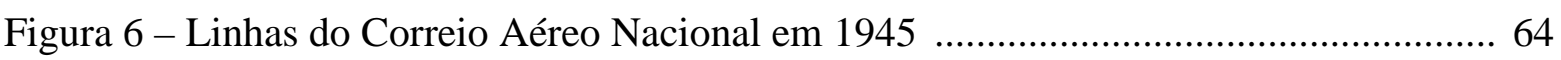

Figura 7 - Etapas da integração do território brasileiro pelo correio entre 1663 e 2016 ..... 81

Figura 8 - Imagem de satélite do aeroporto de Louisville-KY, EUA ............................. 129

Figura 9 - Modelo de objeto postal com seus elementos principais ................................ 140

Figura 10 - Estrutura do CEP no Brasil .......................................................................... 154

Figura 11 - Interface do Sistema de Rastreamento de Objetos dos Correios ................... 157

\section{LISTA DE FLUXOGRAMAS}

Fluxograma 1 - Modelo simples e detalhado do esquema de captação e entrega dos

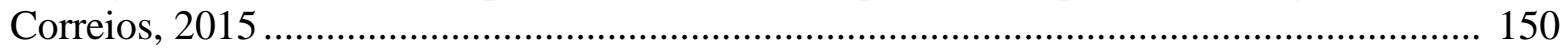

Fluxograma 2 - Esquema geográfico da logística dos Correios no Brasil, 2016............... 152

\section{LISTA DE FOTOGRAFIAS}

Fotografia 1 - Agência de postagem no bairro de Lakeview, Chicago-IL, EUA ..... 109

Fotografia 2 - Veículos de empresas de correio realizando entregas ao mesmo tempo no centro de Manhattan, New York-NY, EUA.

Fotografia 3 - Caixa de coleta para postagem de correspondências da empresa pública Canada Post/Postes Canada em logradouro da cidade de Montréal, Québec, Canadá ....... 109 Fotografia 4 - Caixa de coleta para postagem de correspondências da empresa privada UPS em logradouro da cidade de Toronto, Ontario, Canadá

Fotografia 5 - Veículo de entrega da empresa UPS em logradouro da cidade de Lexington, Kentucky, EUA, com o slogan "worldwide services"

Fotografia 6 - Veículo de entrega da empresa UPS em logradouro da cidade de Montréal, Québec, Canadá, com o slogan "services mondiaux".

Fotografia 7 - Veículo de entrega da empresa UPS na Avenida Paulista em São Paulo-SP, Brasil, com o slogan "serviços mundiais" 
Fotografia 8 - Operações da UPS e rígido controle de acesso no centro logístico Worldport em Louisville, Kentucky, EUA....

Fotografia 9 - Parte da área externa do centro logístico Worldport da empresa UPS em Louisville, Kentucky, EUA

Fotografia 10 - Área do entorno do centro logístico Worldport da UPS em Louisville-KY, EUA.

Fotografia 11 - Máquina de triagem de objetos do CTE Jaguaré, São Paulo-SP

Fotografia 12 - Campus da Universidade Corporativa dos Correios, em Brasília-DF.

Fotografia 13 - Edifício-sede dos Correios, em Brasília-DF.

Fotografia 14 - Caminhão dos Correios deixando o CTE Jaguaré em São Paulo-SP com destino ao Rio de Janeiro-RJ

Fotografia 15 -- Exemplar do primeiro modelo brasileiro de caixa de coleta (século XIX), encontrado no Museu dos Correios

Fotografia 16 - Veículo de entrega da empresa DHL no bairro da Liberdade, em São PauloSP

Fotografia 17 - Veículo de entrega da empresa FedEx no bairro dos Jardins, em São PauloSP

Fotografia 18 - Veículo de entrega dos Correios na favela de Paraisópolis, zona sul de São

Paulo

Fotografia 19 - Carrinho de entrega dos Correios em calçadão da cidade de CuritibaPR

Fotografia 20 - CTE Jaguaré, na zona oeste de São Paulo

Fotografia 21 - Loja de peças para motocicletas com entrega via SEDEX para todo o Brasil, localizada no centro da cidade de São Paulo

\section{LISTA DE GRÁFICOS}

Gráfico 1 - Receita anual (entre 2000 e 2015) das principais empresas de correio que operam nos EUA, em bilhões de dólares

Gráfico 2 - Receita anual da empresa FedEx entre os anos de 1980 e 2015, em bilhões de dólares

Gráfico 3 - Percentuais do rendimento total do setor postal por segmento de serviço nos anos de 2004 e 2014

Gráfico 4 - Fluxo postal no Brasil em bilhões de objetos postados em anos selecionados entre 1979 e 2015 .

Gráfico 5 - Percentuais do total de objetos postados por região do Brasil em 1987 e 2015.

\section{LISTA DE MAPAS}

Mapa 1 - Brasil: integração territorial pelo correio, 1663-1842 ….................................... 52

Mapa 2 - Brasil: integração territorial pelo correio, 1843-1930 ......................................... 60 
Mapa 3 - Brasil: integração territorial pelo correio, 1931-1968. 67

Mapa 4 - Brasil: integração territorial pelo correio, 1969-1981 ........................................ 71

Mapa 5 - Brasil: integração territorial pelo correio, 1982-2016........................................ 79

Mapa 6 - Mundo: monopólio postal estatal, 2016 ...................................................... 101

Mapa 7 - Mundo: rede da FedEx, 2016 ........................................................................ 116

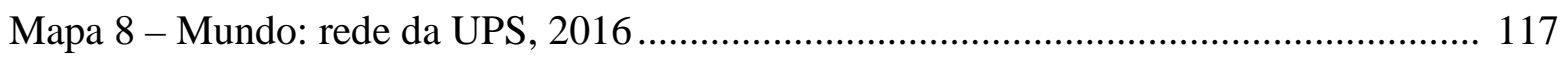

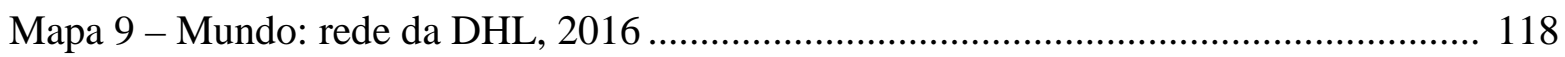

Mapa 10 - EUA: principais centros logísticos de correio privado, 2016 ......................... 123

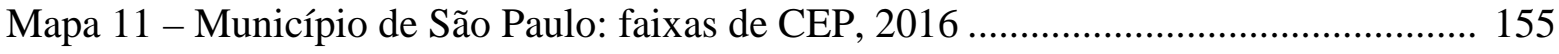

Mapa 12 - Brasil: rede de transporte aéreo de carga dos Correios em 2016 ..................... 164

Mapa 13 - Brasil: prazos de entrega dos Correios, 2016 .............................................. 170

Mapa 14 - Rede urbana brasileira em 2007 ................................................................. 185

Mapa 15 - Brasil: fixos postais especializados em serviços expressos, 2016 ................... 192

Mapa 16 - Região Metropolitana de São Paulo: fixos postais especializados, 2016......... 206

\section{LISTA DE ORGANOGRAMAS}

Organograma 1 - Linha do tempo (1500-2016) com diferentes periodizações da história postal brasileira segundo os autores e duração dos períodos, 2016

\section{LISTA DE QUADROS}

Quadro 1 - Estudos sobre o correio, segundo as áreas de conhecimento ........................... 29

Quadro 2 - Síntese da proposta de periodização ............................................................. 47

Quadro 3 - Dias e horários de partida das malas postais do Rio de Janeiro para o interior do

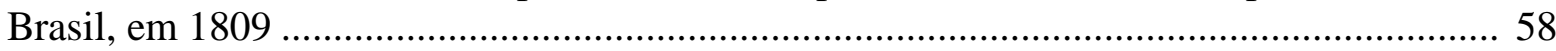

Quadro 4 - Principais diferenças entre o correio tradicional e o correio moderno............... 90

Quadro 5 - Simulação de preços e prazos de entrega de empresas de correio com atuação nos EUA para a postagem de um pacote de $1 \mathrm{lb}$ (aprox. meio $\mathrm{kg}$ ) entre as cidades de New York-NY e Los Angeles-CA, em janeiro de 2016 .......................................................... 108

Quadro 6 - Perfil de empresas públicas (ECT e USPS) e privadas (FedEx, UPS e DHL) de

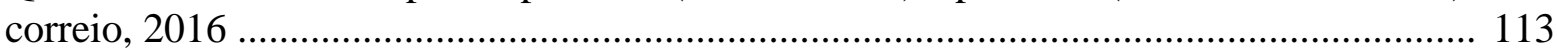

Quadro 7 - Tipologia dos serviços postais nacionais dos Correios no Brasil, 2016 .......... 145

Quadro 8 - Turnos de trabalho do Centro de Tratamento de Encomendas Jaguaré, em São

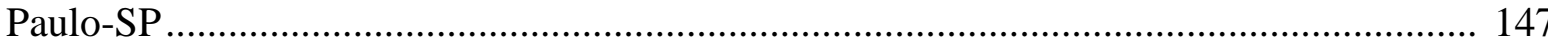

Quadro 9 - Matriz de prazos de entrega de serviços expressos dos Correios em dias por

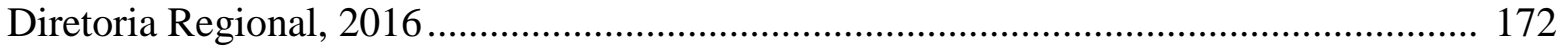

Quadro 10 - Tipologia dos principais fixos geográficos postais no Brasil, 2016.............. 188

Quadro 11 - Volume total de correspondências dos Correios (percentuais) por origem e destino conforme regiões do Brasil, 2015 


\section{LISTA DE TABELAS}

Tabela 1 - Desenvolvimento do Correio Aéreo Nacional nos dezesseis primeiros anos

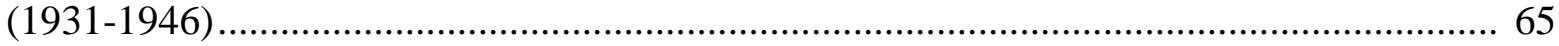




\section{LISTA DE ABREVIATURAS E SIGLAS}

$\mathrm{AC}$

$\mathrm{ACC}$

$\mathrm{ACF}$

$\mathrm{AF}$

AICEP

AIEA

APWU

AR

CAM

CAN

CAPP

$\mathrm{CC}$

$\mathrm{CD}$

CDD

CEE

CEP

CGA

CLI

CNPJ

COI

COL

$\mathrm{CPF}$

CTC

CTCE

CTCI

CTE

DCT

DENAF

DIT

ECOBOL

ECT
Agência de Correios

Agência de Correios Comunitária

Agência de Correios Franqueada

Agência Filatélica

Associação dos Operadores de Correios e Telecomunicações dos Países e Territórios de Língua Oficial Portuguesa

Agência Internacional de Energia Atômica

American Postal Workers Union

Aviso de Recebimento

Correio Aéreo Militar

Correio Aéreo Nacional

Comissão Permanente Árabe de Correios

Caixa de Coleta

Centro de distribuição

Centro de Distribuição Domiciliária

Centro de Entrega de Encomendas

Código de Endereçamento Postal

Compagnie Genérale d'Enterprises Aéronautiques

Centro de Logística Integrada

Cadastro Nacional de Pessoa Jurídica

Comitê Olímpico Internacional

Centro de Operações Logísticas

Cadastro de Pessoa Física

Centro de Tratamento de Cartas

Centro de Tratamento de Cartas e Encomendas

Centro de Tratamento de Correio Internacional

Centro de Tratamento de Encomendas

Departamento de Correios e Telégrafos

Departamento de Encaminhamento e Administração da Frota

Divisão internacional do trabalho

Empresa de Correos de Bolívia

Empresa Brasileira de Correios e Telégrafos 
EMS Express Mail Service

ENADE Exame Nacional de Desempenho de Estudantes

ENEM Exame Nacional do Ensino Médio

ESAP Escola Superior de Administração Postal

EUA Estados Unidos da América

FAC Franqueamento Autorizado de Cartas

FNDE Fundo Nacional de Desenvolvimento da Educação

IATA Associação Internacional de Transporte Aéreo

IBGE Instituto Brasileiro de Geografia e Estatística

LCE Linhas de Coleta e Entrega

LT Linhas Tronco

LTA Linhas Tronco Auxiliares

LTI Linhas Tronco Internacionais

LTN Linhas Tronco Nacionais

LTR Linhas Tronco Regionais

LTU Linhas Tronco Urbanas

MEC Ministério da Educação

OMC Organização Mundial do Comércio

OMS Organização Mundial da Saúde

ONG Organização não-governamental

ONU Organização das Nações Unidas

PA Posto de Atendimento Avançado

PNLD Programa Nacional do Livro Didático

POSTEUROP Associação dos Operadores Postais Públicos Europeus

PV Posto de Vendas de Produtos

REGIC Regiões de Influência das Cidades

RMSP Região Metropolitana de São Paulo

RPN Rede Postal Aérea Noturna

SARA Sistema de Automação da Rede de Atendimento

SCCE Sistema de Conferência de Cargas e Encomendas

SEDEX Serviço de Encomenda Expressa Nacional

SIGEP Sistema de Gerenciamento de Postagem

SILCTE Sistema Local do Centro de Tratamento de Encomendas 
Diretoria São Paulo Interior

SRO

Sistema de Rastreamento de Objetos

TECA Terminal de Cargas

UD Unidade de Distribuição

UE União Europeia

UIT

União Internacional de Telecomunicações

UNESCO Organização das Nações Unidas para a Educação, Ciência e Cultura

UniCo Universidade Corporativa dos Correios

UPA União Postal Africana

UPAEP União Postal das Américas, Espanha e Portugal

UPAP União Pan-Africana de Correios

UPC União Postal do Caribe

UPS United Parcel Service

UPSOA União Postal do Sul e do Sudoeste da Ásia

UPU União Postal Universal

USPS United States Postal Service 


\section{SUMÁRIO}

INTRODUÇÃO .....................................................................................................................21

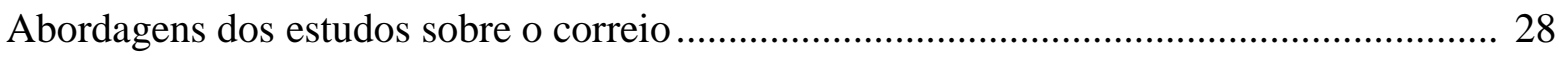

Caminhos teórico-metodológicos da pesquisa ................................................................. 33

CAPÍTULO 1 - O CORREIO NA FORMAÇÃO SOCIOESPACIAL BRASILEIRA: UMA PROPOSTA GEOGRÁFICA DE PERIODIZAÇÃ̃ ........................................... 38

1.1. Periodizar a história do correio no Brasil: um esforço de método ................................ 41

1.2. Primeiro período (1663-1842): o território extravertido e o tempo lento das

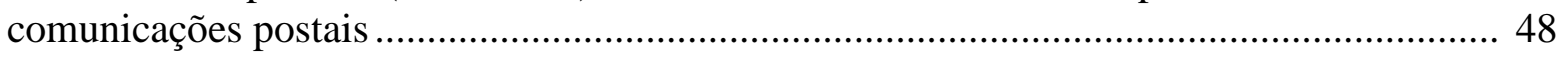

1.3. Segundo período (1843-1930): do selo ao telégrafo - o início da integração do

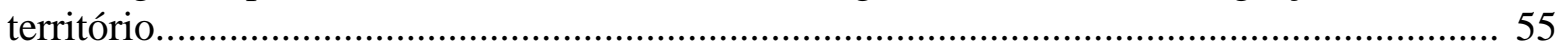

1.4. Terceiro período (1931-1968): o Departamento de Correios e Telégrafos e o projeto geopolítico de integração territorial

1.5. Quarto período (1969-1981): a Empresa Brasileira de Correios e Telégrafos e a consolidação da integração territorial

1.6. Quinto período (1982-dias atuais): os serviços expressos e a diferenciação do território.

CAPÍTULO 2 - OS SERVIÇOS POSTAIS NA GLOBALIZAÇÃO ................................. 83

2.1. Do correio tradicional ao correio moderno .................................................................... 86

2.2. Monopólio postal estatal versus monopólio privado ................................................ 100

2.3. Território e fronteira nacional na circulação de objetos postais.................................. 111

2.4. O uso corporativo do território e a conformação de uma região especializada no centro

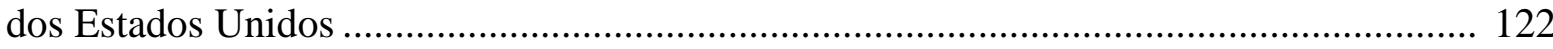

CAPÍTULO 3 - A LOGÍSTICA DOS CORREIOS NO BRASIL: RACIONALIDADE, VELOCIDADE E FLUIDEZ TERRITORIAL .................................................................. 132

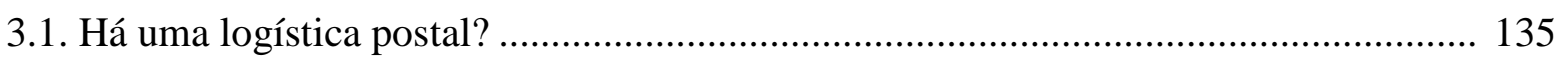

3.1.1. Notas conceituais sobre logística............................................................. 136

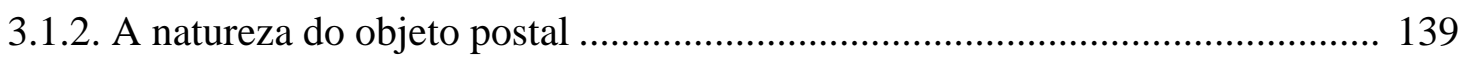

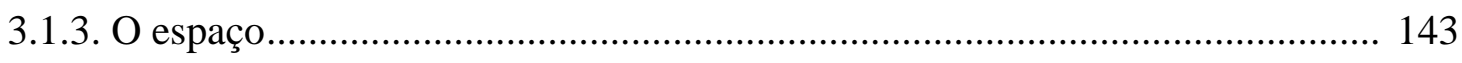

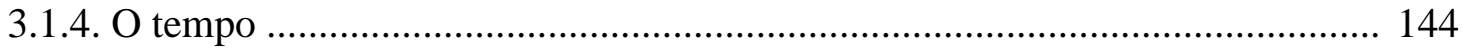

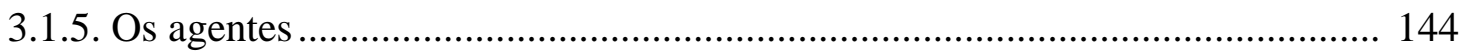

3.2. A complexidade técnica e a racionalização da rotina operacional dos Correios ......... 145

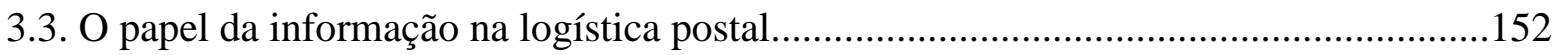

3.4. Os prazos de entrega dos Correios no Brasil: fluidez e viscosidade territorial............ 160

3.4.1. Os modais de transporte na logística dos Correios ....................................... 161

3.4.2. Os prazos de entrega: uma expressão do território desigual........................... 168 
3.5. O frenesi da velocidade e a diversificação dos serviços

3.5.1. Os serviços expressos e os espaços da rapidez

3.5.2. Os serviços não expressos e os espaços da lentidão

\section{CAPÍTULO 4 - CORREIOS, REDE URBANA E DIVISÃO TERRITORIAL DO}

4.1. Aspectos da rede urbana brasileira no início do século XXI 182

4.2. Tipologia e topologia dos Correios e rede urbana: similitudes e diferenças 186

4.2.1. Os fixos postais 186

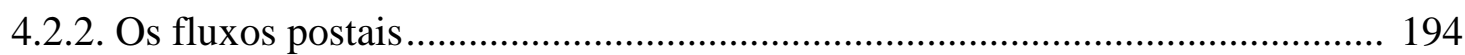

4.3. A divisão territorial do trabalho imposta à atividade postal ...................................... 199

4.3.1. As regiões brasileiras e os fluxos postais ..................................................... 200

4.3.2. A centralidade de São Paulo ............................................................................ 205

4.4. Estado-território-mercado e planejamento: de lugares para a logística a uma logística

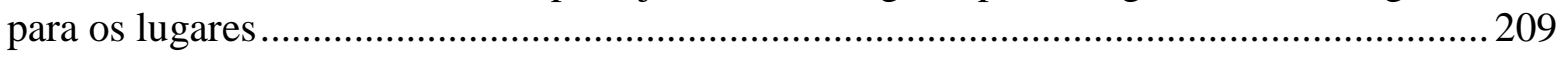

4.4.1. O correio como infraestrutura do território ................................................. 209

4.4.2. Os Correios para além do serviço postal ....................................................... 213

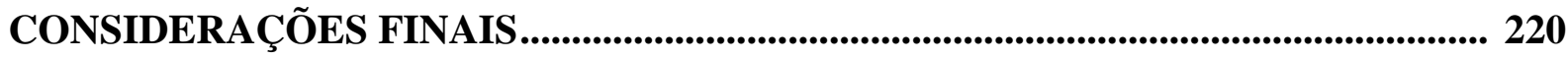

REFERÊNCIAS .................................................................................................................. 227

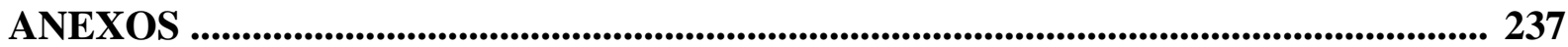


O século XX finda marcado por uma desordem global de natureza incerta. As contradições típicas do modo de produção capitalista são agora ampliadas e diluídas em todas as esferas sociais, desafiando teorias e utopias diversas (HOBSBAWM, 1995). Praticamente todos os países acabam por adotar um sistema político-econômico convergente, além de assistirmos à unicidade técnica que alcança todas as latitudes (SANTOS, [1994] 2008c). Os avanços tecnológicos e o comando do espaço e do tempo são buscados pelas empresas e o Estado, impelidos pela concorrência (HARVEY, [1989] 2011). Neste contexto, retomam-se, entre os cientistas sociais, as preocupações com o território, e a constatação mesma de que "as grandes contradições do nosso tempo passam pelo uso do território" (SANTOS, [1993] 2006, p.19) recoloca o espaço geográfico e o território no centro do debate sobre a sociedade contemporânea.

No entanto, muitas teorias foram elaboradas, no final do século XX e neste início do século XXI, versando sobre o fim das coisas. Animados pela queda do Muro de Berlim e o esfacelamento da União Soviética, mas também pelo que comumente passou a ser chamado de globalização, alguns autores chegaram a anunciar o fim da história (FUKUYAMA, 2006), das distâncias (CAIRNCROSS, 2001), das fronteiras (OHMAE, 1999) e até mesmo o fim dos territórios nacionais (BADIE, 1995) e da geografia (O'BRIEN, 1992). Essa vertente escatológica das análises sociais ganhou destaque no momento em que o foco apenas nas escalas global e local esvaneceu as figuras do Estado e do território nacional, que para Moraes (2005, p.141) "só tomam sentido quando se aborda o espaço e a sociedade em termos nacionais". Contrariamente às proposições catastróficas, a realidade atual nos revela o aumento da importância do espaço e da localização em todos os âmbitos sociais, do econômico ao cultural, do político ao subjetivo e individual; mas também em todas as escalas, fazendo com que o nacional antes mude de conteúdo e qualidade do que seja constatado o seu desaparecimento.

$\mathrm{Na}$ esteira dos fins anunciados, o correio foi uma atividade declarada ultrapassada e teve sua utilidade questionada face ao advento da Internet. Para Virilio ([1984] 2014), o correio teria esvaecido com a revolução tecnológica que alterou profundamente as formas tradicionais de comunicação que permitem hoje a instantaneidade da informação. Na década de 1990, principalmente, o discurso do fim do correio, ao lado dos ideais neoliberais, justificou inúmeros casos de abandono e privatização de empresas de correio nacionais, em diversos países.

Longe de eliminar ou reduzir a importância do correio, a Internet tem impulsionado os serviços postais. Se, por um lado, o tradicional mail (correio) foi sendo rapidamente 
substituído pelo e-mail (correio eletrônico), as empresas de serviço postal foram beneficiadas, por outro lado, pelo advento do e-commerce (comércio eletrônico), já que a compra e pagamento virtual de mercadorias não prescinde da circulação física dos objetos e exige condições específicas de distribuição e prazos flexíveis de entrega. Do contrário, os volumes crescentes de compras online parecem anunciar uma nova fase áurea do correio, longe mesmo de seu fim.

Nesse contexto, uma atividade tradicional de entrega de mensagens e pequenas encomendas - os serviços postais - conhece uma verdadeira transformação das funções do correio pela introdução da moderna logística; uma mudança duplamente quanti e qualitativa nos últimos anos. Entre 1980 e 2014, o total mundial de objetos postais salta de pouco mais de 200 para 334 bilhões de cartas e encomendas ${ }^{1}$, sendo que estas últimas registraram crescimento ainda maior, mais que triplicando o seu número em três décadas ${ }^{2}$. Esse crescimento não ocorreu desacompanhado do aumento da receita do setor postal, que era de 69 bilhões de dólares estadunidenses há três décadas e alcançou a cifra de US\$ 334 bilhões no ano de 2014. No entanto, para que essa circulação crescente pudesse ser realizada não foi necessário um aumento correspondente do número de agências de correio nem dos trabalhadores, um indicativo dos processos de automação, de um lado, e da melhoria dos métodos racionais de gestão e controle do trabalho, de outro. Das 513 mil agências existentes em 1980, chega-se atualmente em 679 mil; do mesmo modo, o número de trabalhadores em atividades do correio no mundo era de 4,6 milhões naquele ano e hoje gira em torno dos 5,2 milhões.

Entretanto, o crescimento vertiginoso do correio na passagem para o século XXI não significou o fim das desigualdades de acesso aos serviços. Enquanto quase a totalidade dos domicílios da Europa, Estados Unidos, Canadá, Japão e Coréia do Sul contam com serviços de entrega, na África apenas $21,6 \%$ dos domicílios são alcançados pela entrega domiciliar ${ }^{3}$. Do mesmo modo, se os territórios dos países mais avançados da economia capitalista contam com uma agência de correio para cada $195 \mathrm{~km}^{2}$, a cobertura cai para $421 \mathrm{~km}^{2}$ por agência na América Latina e nos países africanos a rarefação é ainda maior, com uma unidade para cada

\footnotetext{
${ }^{1}$ Os números apresentados na sequência foram extraídos do site da União Postal Universal no endereço http://www.upu.int/en/resources/postal-statistics/about-postal-statistics.html.

${ }^{2}$ Segundo dados da UPU, foram postadas aproximadamente 2 bilhões de encomendas no mundo inteiro em 1980, cujo crescimento exponencial permitiu registrar a quantidade de mais de 7 bilhões em 2014.

${ }^{3}$ De acordo com os dados da UPU para 2014, a entrega domiciliar é realizada nos seguintes percentuais de domicílios por continente ou grupo de países: África - 21.6\%; América Latina e Caribe - 84,9\%; Ásia e Pacífico - 98,5\%; Europa e ex-URSS; 97,1\%; países árabes - 63,3\%; países industrializados - 96,6\%. A média mundial é de $85,6 \%$.
} 
$1520 \mathrm{~km}^{2}$. Consequentemente, se a média mundial em 2014 era de um trabalhador de correio para cada grupo de mil e trezentos habitantes, os países mais avançados contam com o conforto de ver essa média reduzida para 381 pessoas servidas por trabalhador, enquanto a África se caracteriza pela escassez, com somente um trabalhador de correio para cada 15 mil habitantes.

Essas desigualdades são produto de um desenvolvimento histórico do correio no seio das contradições sociais, que são acirradas de forma crescente sob o capitalismo. É o historiador Fernand Braudel ([1966]1983) que demonstra o desenvolvimento do correio na Europa a partir de uma série de mapas correspondentes aos séculos XVI, XVII e XVIII (Figuras 1, 2 e 3). Cada círculo concêntrico a partir da cidade de Veneza representa uma semana de viagem das cartas e as linhas em cinza simbolizam o que hoje chamaríamos de "fluidez territorial": quanto mais espessa, mais fluído era o território para a circulação das cartas naquela direção. É também notório que a distância entre um raio e outro não segue um padrão equivalente, já que existem vastas áreas onde a garantia do mesmo prazo de entrega já era possível.

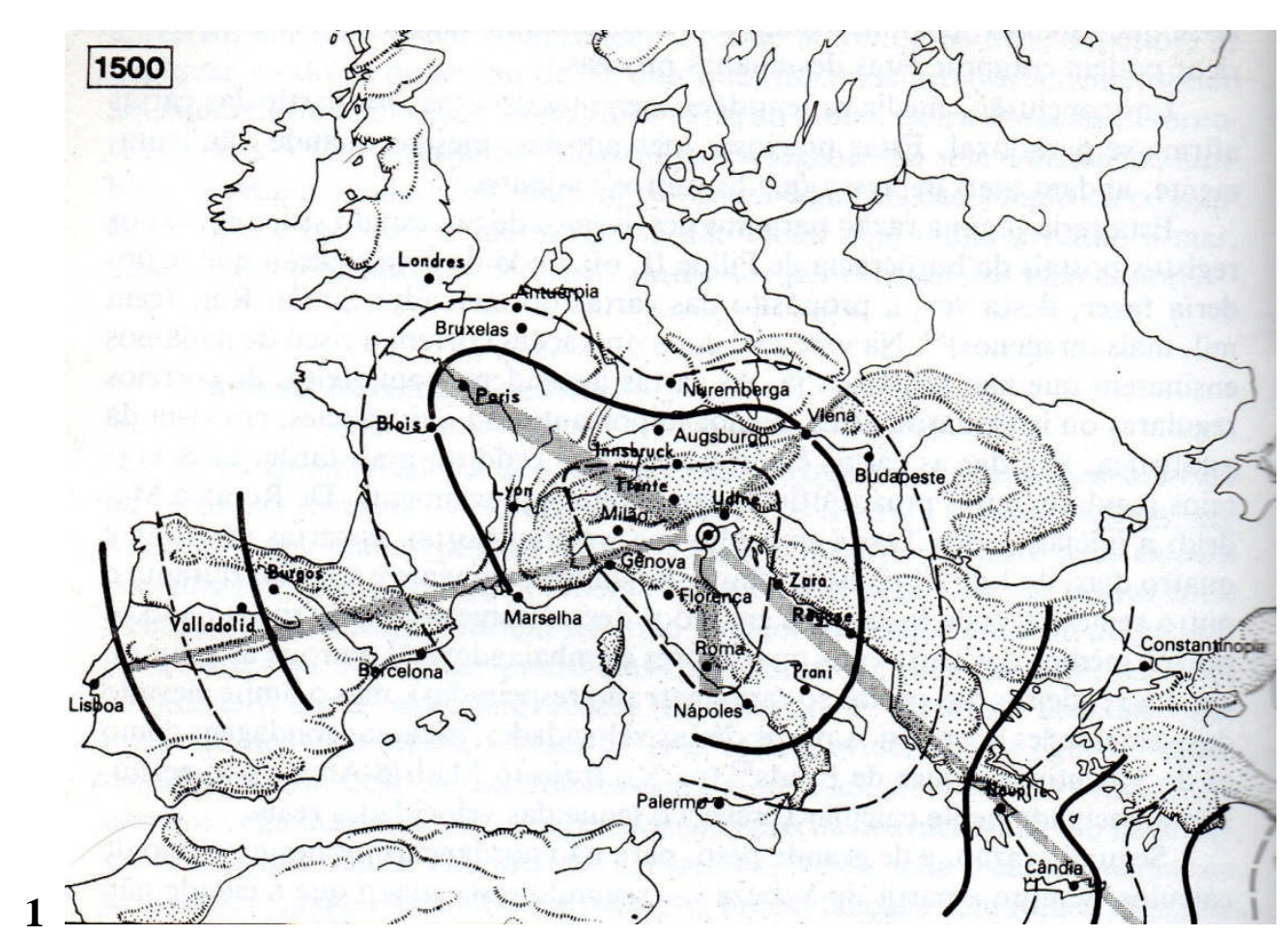

Figura 1 - Tempo de entrega de correspondências em Veneza a partir da Europa em 1500. Fonte: Braudel, [1966] 1983, vol.1, p.414.

Nota: Os anéis concêntricos a partir de Veneza representam o prazo de entrega de cartas de uma semana. As setas em cinza apontam para as regiões onde os fluxos postais alcançavam maior velocidade. 


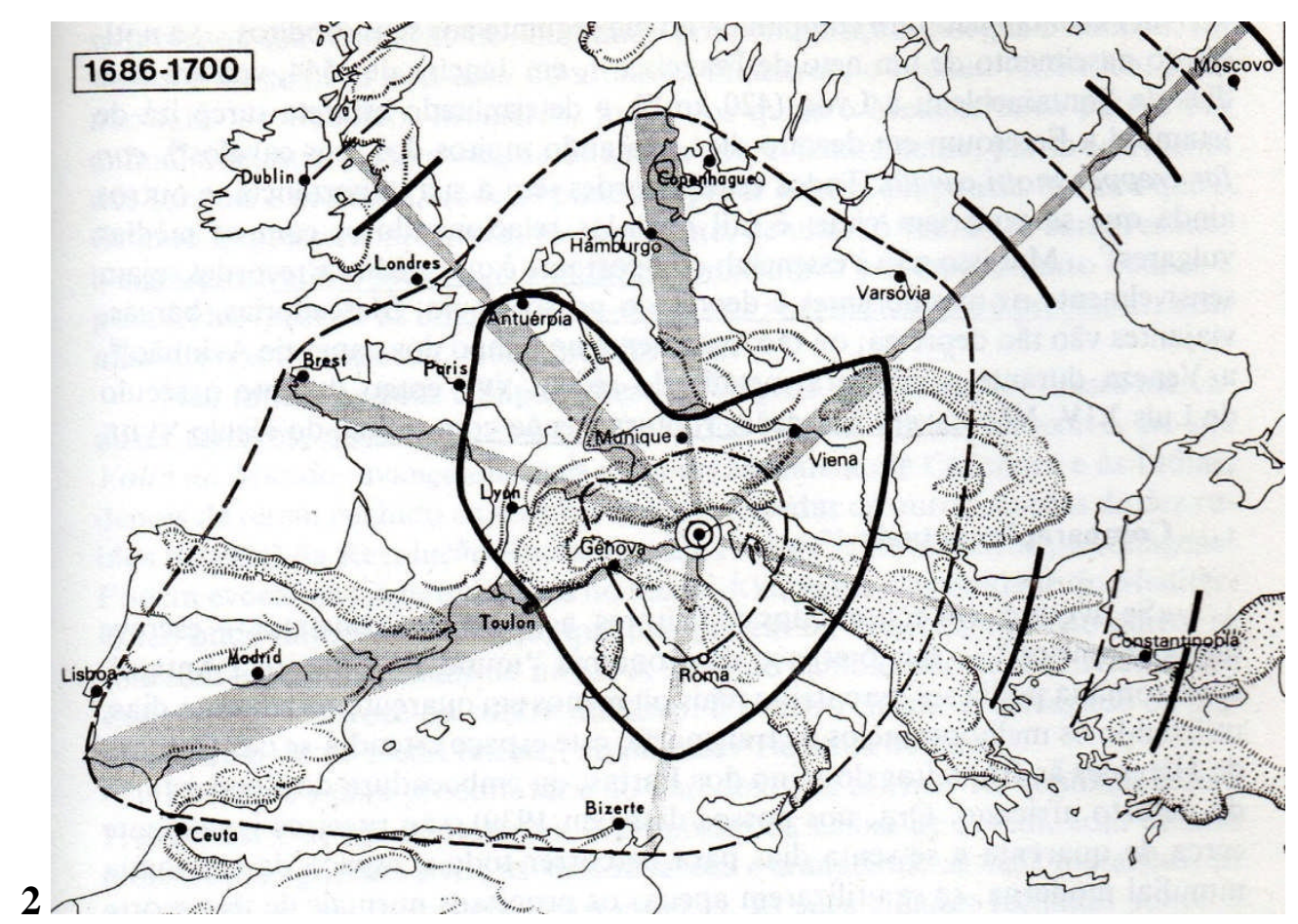

Figura 2 - Tempo de entrega de correspondências em Veneza a partir da Europa entre 1686 e 1700. Fonte: Braudel, [1966] 1983, vol.1, p.415.

Nota: Os anéis concêntricos a partir de Veneza representam o prazo de entrega de cartas de uma semana. As setas em cinza apontam para as regiões onde os fluxos postais alcançavam maior velocidade.

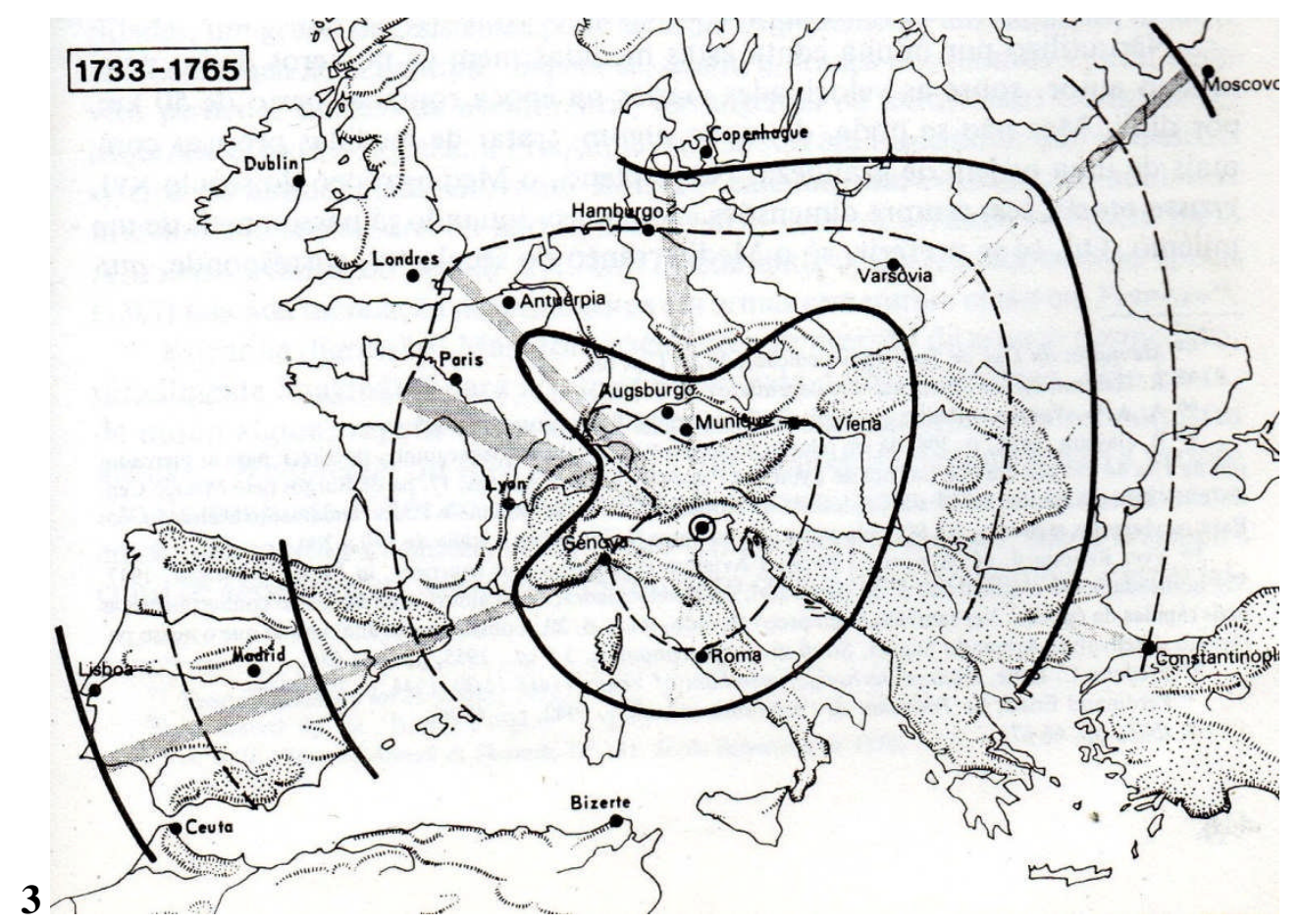

Figura 3 - Tempo de entrega de correspondências em Veneza a partir da Europa entre 1733 e $1765 .$.

Fonte: Braudel, [1966] 1983, vol.1, p.415.

Nota: Os anéis concêntricos a partir de Veneza representam o prazo de entrega de cartas de uma semana. As setas em cinza apontam para as regiões onde os fluxos postais alcançavam maior velocidade. 
A riqueza dos mapas pode ser evidenciada em diversos elementos apresentados. Destacam-se as áreas de relevo montanhoso do continente e o traçado dos rios apresentados, pois, principalmente naquela época, o transporte das correspondências não podia fugir das dificuldades impostas pelo espaço, implicando diretamente no tempo de entrega das cartas. Além da distância, outras condições geográficas implicam no tempo de entrega das correspondências: o relevo e a hidrografia; as técnicas de transporte utilizadas; as fronteiras e as implicações políticas dos territórios nacionais que se delimitavam; fatores econômicos e outras especificidades dos lugares. Os mapas de Braudel apresentam ainda outra contribuição de destacada notoriedade: no século XVIII (Figura 3), o tempo de entrega das cartas aumenta, principalmente em partes da França e na Península Ibérica, se comparado com o século anterior (Figura 2), contrariando qualquer abordagem possivelmente linear ou evolucionista do fenômeno, demonstrando que as condições de fluidez não são decorrentes somente dos avanços técnicos, mas de uma série de determinações econômicas, políticas, sociais e territoriais.

Atualmente, a segmentação do objeto postal articula os espaços em prazos diferenciados por serviços mais ou menos rápidos (expressos) e tende a apresentar, em algumas regiões, somente pontos com tempo de entrega semelhante e, em outras, uma vasta área contínua de maior fluidez. Seriam os paradigmas de área ou zona e de redes insuficientes, se tomados isoladamente, para explicar a complexidade do espaço geográfico? Uma possível resposta seria que entender o correio hoje demanda romper com uma visão dicotômica entre redes e áreas ou zonas para assumir o território em sua totalidade como elemento explicativo.

Falar em território e seus usos extrapola as questões econômicas para alcançar a esfera política (KAHIL, 2012). A discussão em torno do correio brasileiro nos leva a indagar alguns de seus aspectos peculiares. No Brasil, a União detém o monopólio dos serviços postais, assegurado pela Constituição Federal de 1988 e pela Lei 6538/78 (Lei Postal). Assim, falar em serviços postais no país é sinônimo de Empresa Brasileira de Correios e Telégrafos (ECT) ou Correios, já que à empresa compete a execução dos serviços ${ }^{4}$. Na leva de privatizações pela qual passou o Brasil antes da virada do milênio, poucos setores foram preservados,

\footnotetext{
${ }^{4}$ Para a leitura do trabalho, é necessário realizar uma distinção inicial entre os termos correio e Correios. O primeiro corresponde genericamente aos serviços postais, em qualquer porção do espaço e em qualquer momento da história. Já Correios faz referência à Empresa Brasileira de Correios e Telégrafos (ECT), nome próprio da instituição estatal que realiza os serviços postais no país a partir do final da década de 1960. No Brasil atual, correio e Correios confundem-se, já que na maioria dos casos somente à empresa é reservado direito de realizar a prestação dos serviços.
} 
destacando-se o setor postal. A especificidade mesma de um serviço postal estatal - e, importante frisar, eficiente - coloca o correio brasileiro entre os casos mais interessantes e, por isso mesmo, demandante de elucidação adequada no período atual. É um diferencial do correio do Brasil face à dimensão privatizada do setor postal em outras porções do mundo e à monopolização dos operadores logísticos em geral. Cumpre-nos indagar que interesse possui o Estado na manutenção desse monopólio e quais as suas articulações com o mercado e com o uso e controle do território nacional. Haveria um projeto de integração nacional movido pelo Estado por meio do correio? Em caso afirmativo, quais lógicas regem a sua implantação?

É mister indagar quais seriam as estratégias de uso do território brasileiro pelos Correios para garantir maior racionalidade e velocidade aos serviços postais, assegurando, ao mesmo tempo, seu caráter público e universal. Sob o slogan "mandou, chegou", todas as cidades brasileiras são convocadas a participar, de alguma maneira, da logística empregada pela empresa. Qual seria o papel desempenhado por São Paulo, a metrópole das metrópoles (SANTOS, [1994] 2008c), onipresente e informacional (BERNARDES SILVA, 2003), na topologia desenhada pelos Correios no Brasil? Que funções são atribuídas às demais metrópoles e cidades médias sob a lógica adotada pelos Correios?

Também sabemos que as diferenças regionais não podem ser desconsideradas, especialmente numa atividade dessa magnitude. Assim, qual é o papel das regiões brasileiras para a circulação atual no correio? Quais são os constrangimentos impostos pelo próprio território a uma logística exigente de prazos flexíveis e dotada de uma capilaridade ímpar? Mais ainda: que temporalidades são impostas por meio da diferenciação de prazos na logística dos Correios e como esta assegura uma articulação dos lugares em rede? Outras questões não menos importantes e atuais estão a exigir uma resposta de cunho geográfico para o problema: qual é o papel da informação na logística dos Correios? Quais são os modais de transporte privilegiados por essa logística no Brasil e que lógicas regem a sua utilização? Que mudanças estratégicas no uso do território brasileiro pelos Correios possibilitaram o surgimento dos serviços expressos e suas sucessivas transformações, garantindo maior racionalidade e fluidez territorial? Como a topologia dessa empresa estatal se confunde com a rede urbana brasileira?

Esta pesquisa tem como objetivo desvelar e analisar as estratégias de uso do território brasileiro pelos Correios para garantir maior racionalidade e velocidade aos serviços postais por meio da logística, compreendendo o papel atual da empresa na formação socioespacial brasileira, sob a tríade Estado-território-mercado.

\footnotetext{
${ }^{5}$ Slogan do serviço SEDEX adotado pelos Correios.
} 
Priorizamos o estudo do serviço expresso porque, além de ser um dos mais rentáveis para os Correios $^{6}$, está constantemente em evidência nas propagandas da empresa. Também este parece ser o serviço que apresentou maiores modificações nos últimos anos (criação de novas modalidades, diversificação de prazos, criação de fixos para atender à demanda, aumento da capilaridade). A atualidade deste estudo também se impõe, neste momento em que o Serviço de Encomenda Expressa Nacional (SEDEX) completa trinta anos no Brasil e reclama um balanço das estratégias de uso do território pelos Correios.

\section{Abordagens dos estudos sobre o correio}

Em face desse conjunto de mudanças, o correio tradicional se complexifica, o que impõe a necessidade de atualização de seu estudo, ao mesmo tempo em que permite às disciplinas/ciências uma abordagem mais fragmentada daquilo que compreendem por correio. Multiplicam-se os estudos e as áreas do conhecimento que, nas últimas décadas, elaboraram um esforço de compreensão do correio no Brasil e no mundo. Assim, realizamos uma ampla revisão bibliográfica, a partir da qual foram selecionadas as áreas de conhecimento que mais se debruçaram sobre a temática - Administração, Ciência Política, Direito, Economia, Engenharia, Geografia, História e Sociologia; para cada área, foram selecionados os trabalhos mais relevantes. Na sequência, após a leitura e fichamento dos trabalhos, foi identificada a problemática central comum aos trabalhos da respectiva área, as palavras-chave que geralmente se destacam nesses estudos e como o correio é abordado em cada uma delas, expressão de uma ou mais de suas dimensões ou funções. A lista de trabalhos não é exaustiva, apenas indica aqueles que foram selecionados como significativos de cada área (Quadro 1).

Os trabalhos em Administração apresentam como problemática central as possibilidades e limites dos modelos gerenciais na tentativa de maximizar o sucesso dos negócios de correio. Com foco nas soluções para o mercado e no grau de empreendedorismo da atividade, o correio é entendido antes como um negócio e que, assim sendo, precisa sempre se reformular para atender às suas metas internas e às expectativas de seus consumidores. Para Martins (2007, p.162), “a responsabilidade econômica da ECT é atendida, pois é uma empresa pública que produz e é rentável", mas também atende sua responsabilidade legal, cumprindo com obrigações legais como "os prazos de pagamento dos salários e encargos sociais"; atende

\footnotetext{
${ }^{6}$ Percentuais da receita líquida de vendas e serviços dos Correios em 2014: Franqueamento Autorizado de Cartas (FAC), 30\%; SEDEX, 24\%; carta, 15\%; PAC, 8\%; Banco Postal, 5\%; mala direta postal, 4\%; rentabilidade de aplicações financeiras, 3\%; outros, 11\%. Fonte: Relatório de demonstrações financeiras de 2014.
} 
sua responsabilidade filantrópica "através da oferta de emprego a pessoas com necessidades especiais", apesar de não cumprir com sua responsabilidade ética "uma vez que a sobrecarga de trabalho interfere nesse aspecto pela questão do estresse e dos casos de depressão".

\begin{tabular}{|c|c|c|c|c|}
\hline $\begin{array}{c}\text { ÁREA DE } \\
\text { CONHECIMENTO }\end{array}$ & PUBLICAÇÕES & $\begin{array}{c}\text { PROBLEMÁTICA } \\
\text { CENTRAL }\end{array}$ & $\begin{array}{l}\text { PALAVRAS- } \\
\text { CHA VE }\end{array}$ & CORREIO \\
\hline Administração & $\begin{array}{c}\text { Barros Neto } \\
\text { (2004); Martins } \\
\text { (2007); Oliveira } \\
\text { (2007); Lopes, } \\
\text { Moura e Oliveira } \\
\text { (2010) }\end{array}$ & $\begin{array}{c}\text { As possibilidades e } \\
\text { limites dos modelos } \\
\text { gerenciais para } \\
\text { maximizar o sucesso } \\
\text { dos negócios de } \\
\text { correio }\end{array}$ & $\begin{array}{l}\text { Negócio; } \\
\text { empreendedorismo } \\
\text { gestão; soluções; } \\
\text { mercado }\end{array}$ & $\begin{array}{l}\text { Organização } \\
\text { postal }\end{array}$ \\
\hline Ciência Política & Eckert (2010) & $\begin{array}{l}\text { Os conflitos de } \\
\text { regulação do correio a } \\
\text { partir de reformas } \\
\text { institucionais e acordos } \\
\text { internacionais }\end{array}$ & $\begin{array}{c}\text { Regulação; } \\
\text { tratados; nacional e } \\
\text { internacional; } \\
\text { controle político; } \\
\text { autonomia }\end{array}$ & $\begin{array}{l}\text { Instituição } \\
\text { postal }\end{array}$ \\
\hline Direito & $\begin{array}{c}\text { Montgomery } \\
(2002) ; \text { Masutti } \\
(2002) ; \text { Carneiro } \\
(2006) ; \text { Xavier } \\
(2007) ; \text { Mesquita } \\
\text { (2012) }\end{array}$ & $\begin{array}{c}\text { O correio como sujeito } \\
\text { de direito nacional e } \\
\text { internacional }\end{array}$ & $\begin{array}{l}\text { Regime jurídico; } \\
\text { monopólio; } \\
\text { legislação; normas; } \\
\text { Estado }\end{array}$ & Setor postal \\
\hline Economia & $\begin{array}{l}\text { Anglade (1946); } \\
\text { Albon (1991); } \\
\text { Bovo (1997) }\end{array}$ & $\begin{array}{c}\text { A viabilidade } \\
\text { econômica na } \\
\text { prestação do serviço de } \\
\text { correio }\end{array}$ & $\begin{array}{l}\text { Privatização; } \\
\text { concorrência; } \\
\text { púbico e privado; } \\
\text { consumidor; } \\
\text { regime de } \\
\text { acumulação }\end{array}$ & $\begin{array}{l}\text { Serviço postal } \\
\text { Empresa } \\
\text { postal }\end{array}$ \\
\hline Engenharia & $\begin{array}{c}\text { Cruz (2007); } \\
\text { Rodrigues, } \\
\text { Nagano e Musetti } \\
\text { (2007); Ji e Chen } \\
\text { (2007) }\end{array}$ & $\begin{array}{c}\text { A elaboração e } \\
\text { avaliação de } \\
\text { estratégias para } \\
\text { otimizar o processo } \\
\text { produtivo do correio }\end{array}$ & $\begin{array}{c}\text { Estratégia; } \\
\text { operação; } \\
\text { desempenho; } \\
\text { automação; } \\
\text { eficiência }\end{array}$ & $\begin{array}{c}\text { Operador } \\
\text { (logístico) } \\
\text { postal }\end{array}$ \\
\hline Geografia & $\begin{array}{c}\text { Gertel (1991); } \\
\text { Aguilar Pérez } \\
\text { (2002; 2004; } \\
\text { 2008); Reguera } \\
\text { (2007); Bowen Jr. } \\
\text { (2012) }\end{array}$ & $\begin{array}{c}\text { O correio como } \\
\text { elemento de integração } \\
\text { territorial }\end{array}$ & $\begin{array}{c}\text { Território; } \\
\text { fronteira; } \\
\text { centralidade; } \\
\text { fluxos; transporte }\end{array}$ & Rede postal \\
\hline História & $\begin{array}{c}\text { Poupard (1979); } \\
\text { Rosário (1993); } \\
\text { Oger (2000); } \\
\text { Henkin (2006); } \\
\text { Marguerit (2010) }\end{array}$ & $\begin{array}{l}\text { O correio como fato } \\
\text { histórico e suas } \\
\text { principais } \\
\text { transformações }\end{array}$ & $\begin{array}{l}\text { Período; evento; } \\
\text { rupturas; } \\
\text { continuidades; } \\
\text { modernização }\end{array}$ & $\begin{array}{l}\text { Administração } \\
\text { postal }\end{array}$ \\
\hline Sociologia & $\begin{array}{l}\text { Walsh (1992); } \\
\text { Teixeira (2013) }\end{array}$ & $\begin{array}{l}\text { A organização do } \\
\text { trabalho no correio e } \\
\text { os embates políticos } \\
\text { entre os diferentes } \\
\text { agentes envolvidos }\end{array}$ & $\begin{array}{l}\text { Trabalho; } \\
\text { sindicalismo; } \\
\text { reestruturação; } \\
\text { gênero; indivíduo }\end{array}$ & $\begin{array}{l}\text { Corporação } \\
\text { postal }\end{array}$ \\
\hline
\end{tabular}

Quadro 1 - Estudos sobre o correio, segundo as áreas de conhecimento.

Fonte: Elaboração própria, a partir de revisão bibliográfica. 
As pesquisas em Administração apontam soluções que visem mitigar os problemas enfrentados nos Correios e assim alcançar uma situação de harmonia, sempre no "intuito de identificar as condições social, cultural e político-administrativa do país e suas correlações com a dinâmica e funcionamento interno da organização" (BARROS NETO, 2004, p.11). O correio é, portanto, entendido como uma organização postal, e como tal carece de estratégias organizacionais para a garantia de seu funcionamento, tendo os trabalhadores, os produtos (mercadorias), as normatizações (internas e externas à organização), os clientes, os fornecedores, o ambiente de negócios, o mercado, a contabilidade, etc. como partes igualmente importantes de um todo sistêmico.

Os conflitos regulatórios no correio são objeto de estudo na Ciência Política, que se acirram com as reformas instituições no âmbito nacional, mas também de acordos bilaterais e internacionais e no interior dos blocos econômicos, como a União Europeia, que passou por um intenso processo regulatório que buscou a assinatura de tratados que permitiram a passagem de uma situação de autonomia nacional para um nível supranacional de regulação e controle político, com vistas à cooperação. O correio é uma instituição postal, ou seja, um conjunto de arranjos institucionais, no seio dos quais os governos nacionais escolhem o tipo de instituição para a qual eles alocam a autoridade regulatória, suas competências e o grau de independência, conforme explica Eckert (2010). Esse arranjo institucional que é o correio passa por mudanças ao longo do tempo e também se diferencia conforme os países e a posição que ocupam no cenário político internacional, em conjunção com as forças internas e externas. O futuro do correio depende, assim, do design institucional a que está submetido e do maior ou menor grau de autonomia dessas instituições.

Muitos trabalhos no Direito se debruçaram sobre a temática do correio. Discutindo os regimes jurídicos, os monopólios - sobretudo os públicos - e principalmente o papel do Estado no seio das transformações pelas quais o correio vem passando no mundo inteiro, as pesquisas versam sobre uma gama variada de temáticas, embora tenham em comum a seguinte problemática central: o correio como sujeito de direito nacional e internacional. Conforme Mesquita (2012, p.10), busca-se um "mergulho na especificidade do setor postal brasileiro", de tal maneira que se recusa "teorias generalizantes, que abstraem peculiaridades centrais para o tratamento e disciplina do setor". O correio é abordado no Direito como o setor postal, como bem destaca Carneiro (2006), o que demanda estudos particulares por parte da disciplina, que se debruça sobre a questão desde a perspectiva da existência de legislações e regulamentações específicas para "um dos setores mais estratégicos da economia mundial" (MONTGOMERY, 2002, p.15). O estudo setorial do correio se vale da interpretação e 
problematização do texto constitucional e das leis vigentes, e das peculiaridades da atividade no conjunto no quadro normativo nacional e internacional.

Os economistas também se comprometeram com o estudo do correio, em sua maioria interessados em explicar sua viabilidade econômica e a satisfação do consumidor, apesar do trabalho de Bovo (1997) se diferenciar por analisar as estruturas econômicas e o impacto dos regimes de acumulação capitalista sobre a organização do trabalho no caso brasileiro. Em todos os estudos, contudo, o traço comum é o tratamento do correio como um serviço postal, portanto uma atividade econômica do setor terciário, e também como uma empresa postal, uma unidade econômica, ora pública, ora privada, que sob um regime de concorrência existe em função da sua reprodução (pelo lucro). Anglade (1946), por exemplo, estudou a importância do serviço postal para a economia nacional na França, relacionando ciclo econômico com a empresa postal e seu rebatimento sobre o tráfego postal e telegráfico. Já as economias de escala e escopo no serviço postal foram estudadas por Albon (1991), que a partir do caso do Reino Unido discutiu privatização e concorrência, traçando um quadro do futuro dos serviços postais no mundo.

O correio também foi abordado pela Engenharia, especialmente em trabalhos mais recentes da chamada Engenharia de Produção. A problemática principal dos estudos versa sobre a elaboração e avaliação de estratégias que buscam aperfeiçoar o processo produtivo do correio, contemplando assim o plano intrafirma muito mais que o exterior à firma. O correio é estudado na perspectiva do "gargalo da operação" (CRUZ, 2007, p.4), elevando a área operacional da empresa à condição de atividade mais importante, sua atividade-fim. $\mathrm{O}$ chamado processo produtivo do correio, que envolve a coleta (postagem), tratamento (triagem), encaminhamento (transporte) e entrega de cartas e encomendas, é unificado sob a logística, uma estratégia operacional agregadora de valor e essencial para o operador (logístico) postal, como é entendido o correio na Engenharia. As agências dos Correios são unidades operacionais e o planejamento de suas ações incorpora as chamadas estratégias operacionais, que envolve uma série de competências; até o trabalhador que lida diretamente com o processo produtivo é entendido como operador. O que a Economia encara como serviço postal, a Engenharia aborda como "operações de prestação de serviços de coleta e entrega de correspondências e encomendas com eficiência e lucratividade" (RODRIGUES; NAGANO; MUSETTI, 2007, p.72). Nessa abordagem, a tecnologia assume um papel primordial na minimização dos custos operacionais, conforme explicitado por Ji e Chen (2007). 
A Geografia, por sua vez, problematizou o correio como elemento de integração territorial. O geógrafo mexicano Reguera (2007) demonstrou como a luta pelo território e as delimitações das fronteiras apareciam nas estampa dos selos postais, uma análise conjunta de filatelia e geopolítica. O correio brasileiro foi estudado por Gertel (1991), que o considerou como um "fato da infraestrutura de uma unidade territorial, participando do desenvolvimento econômico, social e cultural das nações" (GERTEL, 1991, p.114), o que revela a importância dos transportes numa escala extrafirma - a externalidade do território internalizada pela firma. $\mathrm{Na}$ abordagem geográfica, também ganha destaque os estudos sobre o fluxo postal e o papel das centralidades (mormente urbanas) no correio, que os trabalhos de Geografia consideraram como uma rede postal. Bowen Jr. (2012) analisou a dimensão espacial de empresas privadas como FedEx e UPS, revelando sua rede, seus hubs e pontos nodais na escala global. Já o geógrafo Aguilar Pérez produziu vários trabalhos sobre o correio europeu (2002; 2004; 2008), falando em redes postais rurais, nacionais, transnacionais e até mesmo de um correio híbrido, que consistiria da união entre duas redes: uma física, o correio tradicional; outra digital, a Internet. Mas todas essas redes estão inseridas numa problemática controversa, pois, para Gertel (1991, p.170), “a organização do fluxo convencional pelo território, de origem/destino é, também, um fluxo das firmas no território do cidadão".

Preocupados mais com a história do passado que com a história do presente, os historiadores abordaram a problemática do correio como fato histórico - muito mais que um fator, contemplando as transformações derivadas de modernizações sucessivas. Alguns deles, como Rosário (1993) definiram períodos, por meio da eleição dos eventos mais significativos que marcaram esse pedaço da história. De fato, as rupturas assinalam para as mudanças e as continuidades asseguram a movimento do todo, num correio que é entendido na História como administração postal (OGER, 2000), já que assim eram nomeados os correios no passado recente da maioria dos países. O estudo de Henkin (2006) chegou a adjetivar os Estados Unidos por volta da década de 1870 como uma postal society (HENKIN, 2006, p.172), numa revelação da importância do correio para sociedades pretéritas. Os trabalhos em História também apresentam a reprodução de vasto material, como cartas antigas, atos e decretos, imagens, etc.

Por fim, destacamos dois trabalhos que revelam uma abordagem desde a Sociologia, preocupada com a organização do trabalho no correio e os embates políticos entre os diferentes agentes envolvidos. Nos Estados Unidos, destaca-se o estudo de Walsh (1992), que abordou a luta da classe trabalhadora nas greves de correio, em espacial a maior delas e emblemática para o país, ocorrida em 1970. Para o autor, o correio deve ser considerado como 
um expresso humano ou, em suas palavras, human express, um sistema conduzido por seres humanos trabalhando em ambientes longe de serem harmônicos e cumprindo tarefas que exigem habilidades, acurácia e trabalho árduo. No Brasil, a recente tese de doutorado de Teixeira (2013) discutiu as transformações do trabalho nos Correios entre 1994 e 2011, revelando políticas e estratégias de diversos agentes, como o Estado, os governos nacionais, os sindicatos, etc. O autor evidencia o tratamento dado ao correio na Sociologia como uma corporação postal, fruto do processo de corporatização de órgãos da administração pública direta, além de abordar outros temas, como a questão de gênero no cotidiano do trabalho.

Nenhuma das áreas de conhecimento é capaz de estudar o correio em sua totalidade. De fato, para cada uma delas é necessário a eleição das variáveis consideradas essenciais para o entendimento do presente e abordá-las considerando, sempre que possível, o diálogo interdisciplinar para a produção de um conhecimento que seja significativo para a sociedade. Isso porque o debate de alguns aspectos que envolvem o correio, como o monopólio postal ou a privatização, não pode ser assumido somente por uma disciplina específica, mas sim considerando suas múltiplas determinações - política, econômica, técnica, organizacional, normativa, social, histórica e, também, espacial.

\section{Caminhos teórico-metodológicos da pesquisa}

Esta pesquisa adota a dialética como método de interpretação e análise. Para a argumentação, estamos considerando os seguintes pares dialéticos, que serão mais ou menos mobilizados conforme os capítulos: novo/velho, interno/externo, material/imaterial, rápido/lento, integração/diferenciação. Esses pares serão utilizados considerando-se como base da abordagem aqui realizada a tríade Estado-território-mercado (ARROYO, 2004). As categorias técnica e política são centrais na análise que segue, auxiliadas pelas categorias de circulação e informação. Os conceitos de formação socioespacial (SANTOS, [1977] 2008c), divisão territorial do trabalho (SANTOS [1978] 2008a) e uso do território (SANTOS, [1993] 2006) foram utilizados como estruturadores da pesquisa.

Como compreender o particular do espaço geográfico - o território, a região - sem perder de vista a totalidade, articulando-o com o universal - o mundo - e o singular - o lugar? Esta tarefa exige, certamente, ferramentas teórico-metodológicas adequadas, que permitam captar as formas novas e antigas reveladas na paisagem e ainda entender os processos que lhes originam e dão sentido; a vida que as anima, enfim. 
Entre as décadas de 1960 e 1970, a Geografia passou a se valer da categoria de formação econômica e social, cara à tradição marxista e tardiamente incorporada aos estudos geográficos. Esta seria uma categoria totalizante e, segundo Milton Santos ([1977] 2008c), a mais adequada no auxílio à formação de uma teoria valida do espaço, no bojo de uma renovação da disciplina. Ela seria um instrumento legítimo para a explicação da sociedade e seu espaço, já que permite revelar a ordem econômica, a ordem social e a ordem política, paralelas à ordem espacial de objetos permanentemente criados e recriados (SANTOS, [1978] 2008a).

Uma vez que "toda formação social é também territorial, pois necessariamente se espacializa" (MORAES, 2005, p.47), não se trata de formação econômica e social pura e simplesmente; o espaço é uma categoria-chave para o entendimento da formação econômica e social, porque uma dimensão da existência da própria sociedade (SANTOS, [1996] 2012b), uma instância social (SANTOS, [1978] 2008a). Assim, a partir de Milton Santos, a Geografia incorpora a categoria por meio de sua reformulação no conceito de formação socioespacial (SANTOS, [1977] 2008c), revelando a importância do espaço para a realização dos processos sociais e vice-versa, em suas múltiplas determinações:

Afirmamos que se trata muito mais de uma categoria de Formação Sócio-
Econômica e Espacial, pois não há e jamais houve Formação Social
independentemente do espaço. A sociedade não se pode tornar objetiva sem
as formas geográficas. Por outro lado, os objetos que constituem a paisagem
orientam, depois, a evolução da própria sociedade, fato que não tem sido
suficientemente nem sistematicamente indicado (SANTOS, [1978] 2008a,
p. 244 , grifos do autor)

Formação socioespacial é um recurso teórico adequado para o estudo de realidades nacionais; e ainda hoje, quando esta escala é desvalorizada, esquecida, subestimada e até abandonada em muitas análises sociais, no afã dos discursos neoliberais que, mascarando a realidade, declaram a morte do nacional. A importância do conceito advém da constatação de que não pode ser empregado à sociedade em geral, mas a uma sociedade particular, considerando o território nacional como "uma forma histórica específica" (MORAES, 2005, p.54) e permitindo, assim, o estudo concreto de sua realidade, com vistas a posteriores desdobramentos em ações também concretas (SANTOS, [1978] 2008a). Destarte, como manifestação particular do espaço geográfico, a formação socioespacial é o ente mediador entre o lugar e o mundo, elo que assegura a diferenciação espacial.

Dentro de cada formação socioespacial se estabelece uma divisão territorial do trabalho. Esta categoria analítica permite empiricizar a noção de divisão do trabalho, amplamente empregada na tradição marxista. A divisão territorial do trabalho corresponde à 
repartição de tarefas, sempre desigual e combinada, entre as diferentes parcelas do território convocadas a participarem do processo geral de produção. Deste modo, produz-se uma hierarquia de lugares e regiões que se dedicam a atividades mais ou menos especializadas, com implicações sobre as desigualdades entre elas daí derivadas.

Num território assim desigual, as possibilidades de seu uso não são as mesmas para os diversos agentes. As empresas multinacionais, as instituições supranacionais, os Estados e as grandes firmas nacionais são os agentes cuja força política e econômica permite usar o território nacional de maneira plena. Tampouco há consenso social a respeito dos objetivos desses agentes ao realizar o uso do território, sendo que suas intencionalidades e ações divergentes manifestar-se-ão sob a forma de conflitos com expressão territorial.

Para a realização desta pesquisa, foram utilizados diversos procedimentos de investigação. Uma ampla revisão bibliográfica em publicações periódicas e livros nacionais e estrangeiros acompanhou todo o processo, possibilitando, entre outros, o balanço bibliográfico dos estudos sobre o correio apresentado nesta seção. A confecção de uma matriz de eventos permitiu organizar as informações encontradas na revisão bibliográfica e elaborar uma proposta de periodização da história do correio brasileiro.

A pesquisa documental também foi utilizada, com fontes que vão desde as publicações oficiais das empresas e as legislações nacionais até o uso de ferramentas digitais como o Sistema de Rastreamento de Objetos e o Simulador de Prazos e Preços, ambos dos Correios. Nessas fontes foram adquiridos dados sobre os prazos, os modais de transporte utilizados e a localização de unidades operacionais dos Correios.

O trabalho de campo foi um procedimento fundamental para chegar aos resultados aqui apresentados. Ao todo, foram realizados seis trabalhos de campo sistemáticos no Brasil e nos Estados Unidos e várias outras intervenções eventuais para observação e registro fotográfico. No Brasil, foram dois trabalhos de campo realizados em São Paulo, contemplando o Centro de Tratamento de Encomendas (CTE) Jaguaré, o Centro de Tratamento de Cartas (CTC) Leopoldina, o Terminal de Cargas (TECA) Jaguaré, a sede da Diretoria São Paulo Metropolitana dos Correios, para conhecimento dos procedimentos operacionais da empresa, conferência e coleta de dados complementares e realização de entrevista informal ${ }^{7}$; e um trabalho de campo em Brasília, onde foram visitados o Museu dos Correios, a Vice-Presidência de Encomendas dos Correios, a sede nacional dos Correios e a Universidade Corporativa dos Correios, para entrevistas, coleta de dados e registro

\footnotetext{
${ }^{7}$ Sem a gravação de áudio ou resposta formal por escrito, pois não autorizado pelos entrevistados.
} 
fotográfico. Nos EUA foram ao todo três saídas a campo que contemplaram o National Postal Museum e a sede da American Postal Workers Union, ambos em Washington, D.C.; o maior centro logístico (Worldport) da empresa UPS e o Louisville Forward, ambos em Louisville, Kentucky; e o Kentucky Cabinet for Economic Development, em Frankfort, Kentucky. Nesses lugares foram realizadas entrevistas, registro fotográfico e coleta de dados. Ao todo, foram contabilizados nos dois países um total de seis horas de entrevistas formais com agentes do Estado, gestores de empresas públicas e privadas de correio, lideranças de sindicatos de trabalhadores e especialistas no tema (curadores de museus), além das entrevistas informais.

Este trabalho foi financiado pela Fundação de Amparo à Pesquisa do Estado de São Paulo (FAPESP) por meio de bolsas de pesquisa no Brasil e nos Estados Unidos ${ }^{8}$, sem as quais não teria sido possível a realização das etapas anteriormente descritas, especialmente os vários trabalhos de campo realizados. Também deve ser ressaltado o apoio financeiro da instituição para a participação em eventos científicos, que além dos países mencionados também contemplou reuniões em Cuba, Canadá e Polônia. Os estágios e eventos possibilitaram o diálogo com outros pesquisadores e instituições no país e no exterior, com desdobramentos no amadurecimento da pesquisa.

Salientamos que dentre as dificuldades encontradas para a realização de uma pesquisa sobre circulação e logística, a maior delas é a velocidade com que mudam as estratégias utilizadas pelas empresas, de tal modo que durante os três anos de investigação nos deparamos em vários momentos com a necessidade de atualizar as informações já adquiridas. Essa velocidade das mudanças é um dado ao mesmo tempo desafiador e estimulante para o estudo do espaço geográfico, que não pode prescindir a análise do "movimento".

O texto a seguir está estruturado em quatro capítulos, além desta introdução e das considerações finais. No Capítulo 1, apresentamos uma proposta de periodização que divide a história do correio brasileiro em cinco períodos, cada um deles correspondendo a uma etapa específica da integração do território nacional. A seguir, o Capítulo 2 analisa os serviços postais no mundo no atual estágio de globalização, contemplando as principais dimensões da transformação do correio tradicional em correio moderno, a formação dos monopólios estatais e privados e a relevância do território e da fronteira nacional para a circulação do correio. $\mathrm{O}$ Capítulo 3 trata da logística dos Correios no Brasil, demonstrando sua complexidade técnica e informacional e seu desdobramento sobre os prazos de entrega e a diversificação dos serviços

\footnotetext{
${ }^{8}$ Bolsa de mestrado no país: processo FAPESP n ${ }^{\circ}$ 2013/19277-2, sob a supervisão da Profa. Dra. Mónica Arroyo, entre dezembro de 2013 e julho de 2016. Bolsa de estágio de pesquisa no exterior (BEPE): processo FAPESP no 2015/06152-2, realizado na University of Kentucky, em Lexington-KY, EUA, sob a supervisão da Profa. Dra. Susan Roberts, entre agosto de 2015 e janeiro de 2016.
} 
postais. Por fim, no Capítulo 4 será traçada uma tipologia e uma topologia dos fixos e fluxos postais no Brasil e evidenciada a sua relação com a rede urbana e a divisão territorial do trabalho, para apresentar no final as ações dos Correios que extrapolam a própria noção de serviço postal. 
O CORREIO NA FORMAÇÃO SOCIOESPACIAL BRASILEIRA:

UMA PROPOSTA GEOGRÁFICA DE PERIODIZAÇÃO 
A corrida das cartas não passa de um capítulo

da luta contra o espaço

Fernand Braudel, O Mediterrâneo ${ }^{9}$

Como elaborar um estudo da formação socioespacial que considere, indissociavelmente, o espaço e o tempo? Por se tratar de "formação" e não apenas de "forma", a história não pode ser desprezada, se se quer entender os processos. Assim, a periodização comparece como um recurso metodológico indispensável para o estudo da formação socioespacial considerando sua dimensão espaço-temporal em movimento.

Para Roberto Lobato Corrêa, a periodização é, antes de tudo, uma operação intelectual. Ela é sempre uma criação do pesquisador, uma interpretação própria da história específica de seu objeto ou tema de estudo (nunca da história em geral), permitindo definir tempos históricos - os períodos - nos quais o pesquisador dá visibilidade e torna inteligível "a forma específica da existência da totalidade social” (CORRÊA, 2006, p.40). Para Santos ([1994] 2008c, p.67), os períodos são pedaços de tempo que, sob a mesma lei histórica, se definem por características que interagem entre si, assegurando, desta maneira, o movimento do todo.

Para a Geografia, a periodização é um método importante porque pode ser entendida como uma "reconstrução do tempo espacial", nas palavras de Corrêa (2006, p.41); a possibilidade mesma de, unificando espaço e tempo, recontar a história do território. Muito além da simples contextualização do tema ou objeto de estudo, ele permite sua interpretação histórica, dando sentido real à pesquisa. No caso brasileiro, Santos e Silveira ([2001] 2011) demonstraram que, para entender a história de seu território, tanto em seu processo como na sua realidade atual, um esforço de periodização se faz indispensável. Mas como fazê-lo? Para os autores,

A questão é escolher as variáveis-chave que, em cada pedaço do tempo, irão comandar o sistema de variáveis, esse sistema de eventos que denominamos período. Eis o princípio a partir do qual podemos valorizar os processos e reconhecer as novidades da história do território (SANTOS; SILVEIRA, [2001] 2011, p.23, grifo do autor)

Assim, cabe ao pesquisador selecionar aquelas variáveis que julgar mais coerentes com a definição do período e condizentes com a teoria adotada. No entanto, todos os

\footnotetext{
${ }^{9}$ Braudel, [1966]1983, vol.1, p.406.
} 
elementos devem ser considerados em seu conjunto, em sua relação com os demais, num movimento de totalização, reconhecendo, inclusive, a hierarquia das variáveis a fim de definir aquelas consideradas chave para o entendimento do fenômeno (SANTOS, [1978] 2008a). Um exemplo de aplicação do método da periodização para o estudo do espaço geográfico é apresentado em Corrêa (2006) para a rede urbana da Amazônia; também Santos ([1996] 2012b) apresenta uma periodização do próprio espaço geográfico em três períodos, que são também meios geográficos: o natural, o técnico e o técnico-científico-informacional. Essa última proposição é de particular interesse para os objetivos deste trabalho.

$\mathrm{O}$ meio natural correspondia àquele cujos tempos e ritmos eram ditados pela natureza e as técnicas disponíveis eram mais adaptadas do que adaptadoras das condições naturais. Com o percurso da história e o avanço da técnica, deu-se uma verdadeira "substituição de um meio natural, dado a uma determinada sociedade, por um meio cada vez mais artificializado, isto é, sucessivamente instrumentalizado por essa mesma sociedade" (SANTOS, [1996] 2012b, p.233, grifos do autor). O meio natural deu lugar a um meio técnico, cuja adição de objetos ao espaço o transformou numa espécie de prótese do homem, podendo agora realizar atividades antes impossíveis e alterar drasticamente os tempos da natureza, que já é, nos termos de Marx, uma segunda natureza, transformada a partir do trabalho humano. A partir da Segunda Guerra Mundial, a conjunção da técnica com a ciência e a informação ocasionará a emergência de um meio técnico-científico-informacional, fruto do trabalho do homem sobre a materialidade pré-existente da segunda natureza. O meio técnico-científico-informacional, que somente irá se consolidar nos países periféricos do capitalismo a partir da década de 1970, caracteriza-se pelo funcionamento sistêmico dos objetos e pelo maior grau de intencionalidade e racionalidade das ações, ambos - objetos e ações - intensivos em informação como insumo. Os sucessivos meios geográficos não são temporalmente excludentes e nenhum deles ultrapassou os demais, sendo a sua coexistência um dado que assinala o aprofundamento da diferenciação espacial na atualidade.

Ao adjetivar como geográfica esta proposta que ora se apresenta, entende-se que a periodização pode ser elaborada desde diferentes enfoques disciplinares, privilegiando algumas variáveis em detrimentos de outras. Sendo assim, uma periodização desde a Geografia, segundo a nossa perspectiva, assume o espaço geográfico como indispensável para a compreensão e explicação da sociedade e seu movimento histórico. Certamente que outas propostas poderiam ser elaboradas mesmo pela ciência geográfica, principalmente se utilizado outro referencial teórico. No mais, se se aceita a citação de Braudel utilizada como epígrafe 
deste capítulo como verdadeira, a Geografia como uma ciência do espaço pode contribuir substancialmente para o entendimento do correio na atualidade.

\subsection{Periodizar a história do correio no Brasil: um esforço de método}

Revelar o papel do correio no território brasileiro na atualidade é uma tarefa que exige compreender as determinações históricas que permitiram a incorporação de modernizações (tanto ao serviço postal como ao território) e as continuidades e rupturas desse processo. A própria espessura da história postal brasileira - trezentos e cinquenta anos - é um imperativo para que sua apresentação seja sistemática, a partir da definição de períodos e valendo-se da seleção de elementos que sirvam para entender, sobretudo, o presente.

A proposta de periodização apresentada neste capítulo tem por objetivo interpretar a história do correio no Brasil, identificando as condições materiais e normativas do território brasileiro que permitiram a criação e transformação dos serviços postais. Na discussão, pretende-se responder a duas questões principais, quais sejam: que elementos da história postal brasileira auxiliam numa interpretação geográfica do correio no presente permitindo, assim, aprofundar o entendimento do próprio país? Quais são as condições materiais e normativas do território brasileiro que permitiram aos Correios a criação, expansão e transformação dos serviços postais, especialmente os expressos?

Argumenta-se que técnica e política são elementos importantes para uma interpretação geográfica da história postal brasileira. A criação do SEDEX e sua sucessiva difusão pelo território são correspondentes à globalização contemporânea e à criação e expansão do meio técnico-científico-informacional no Brasil, como será demonstrado ao longo do trabalho.

O método geográfico utilizado para a elaboração da periodização assume o referencial teórico de Milton Santos, para quem o espaço geográfico é um "conjunto indissociável, solidário e também contraditório de sistemas de objetos e sistemas de ações, não considerados isoladamente, mas como o quadro único no qual a história se dá" (SANTOS, [1996] 2012b, p.63). Para uma interpretação geográfica da história do correio e definição dos períodos considerou-se, em conformidade com a teoria adotada: Estado, mercado, território, norma, técnica, tempo, meio geográfico e função do correio. A metodologia contou com a elaboração de uma matriz de eventos, organizada em ordem cronológica do ano de 1500 até 2016, distinguindo entre os eventos internos (nacionais) e externos (mundiais) relacionados ao correio brasileiro, alimentada com a revisão bibliográfica e com dados coletados em trabalho de campo e nas entrevistas. 
Ao longo dos períodos, os eventos externos ao território nacional incidem de maneira diferente nos lugares, mediados pela formação socioespacial, dando uma nova feição ao correio brasileiro. Se, por um lado, o Brasil foi um dos primeiros países a adotar o selo postal e a introduzir o telégrafo, de outro o país respondeu diferentemente à leva de flexibilização da regulação postal que afeta as empresas estatais de correio desde meados da década de 1970 . Também a introdução de elementos novos ao correio nacional é mediada pela formação socioespacial, já que, por exemplo, a criação de serviços expressos não abortou o projeto de integração territorial, como verificado em outros países, mas o reforçou e intensificou.

A cada meio geográfico, o correio se organiza de maneira diferente. Da lentidão dos prazos de entrega regidos pelo tempo da natureza, num período quando as únicas modalidades de transporte eram os homens, os animais e os barcos a vela, o correio passa a introduzir os progressos técnicos que a sociedade industrial alcançava, incorporando as ferrovias, o telégrafo e algumas máquinas, garantindo maior celeridade para as mensagens e pequenas encomendas. Agora, o meio técnico-científico-informacional permite ao correio um tempo expresso de entrega e a instantaneidade da informação, graças às tecnologias de rastreamento, assegurando maior racionalidade a todo o processo de circulação postal. As sucessivas transformações da história postal brasileira são correspondentes à sucessão dos meios geográficos. Entretanto, como coexistem diversos meios e diferentes temporalidades, comparecem simultaneamente diferentes estratégias de uso do território e formas de organização do correio, articulando, por exemplo, duas redes de transportes diferentes - a Rede Postal Aérea Noturna e a Rede Fluvial da Amazônia - sob uma mesma logística.

Um olhar detido sobre a história do correio brasileiro revela o papel assumido pela técnica em todos os períodos. Os sucessivos progressos técnicos - dos barcos e animais de carga aos trens, caminhões e aviões - permitiram diferentes estratégias de uso do território, que culminaram em diferentes etapas da integração do território nacional, desde uma circulação extravertida voltada à comunicação com a metrópole lusitana até a integração interna diferenciada dos serviços expressos na atualidade. Também as técnicas adotadas pelo correio são protagonistas das possíveis temporalidades dos prazos de entrega em cada período, revelando nos dias atuais uma aceleração dos fluxos sem precedentes. Conforme a história vai revelando o aumento dos fixos postais, os fluxos se tornam mais extensos e intensos, ou seja, ampliam seu alcance a todo o território e atingem cada lugar mais vezes e com volumes maiores em quantidade e qualidade. A política da universalização do correio pelo território, levada a cabo pelo Estado ao assumir a prestação dos serviços, culmina em garantir, neste início de século, o acesso de um serviço postal público de qualidade a toda a 
população, tornando o correio um importante elo de integração territorial - das pessoas, das empresas, das instituições, dos mercados e dos lugares.

Os períodos da história postal brasileira revelam a tensão entre Estado e mercado, manifestada no território. Conforme explica Arroyo (2004), a tríade território, mercado e Estado é ao mesmo tempo um processo de convergência conceitual e histórica, um elemento explicativo das realidades nacionais em sua interconexão, que será adotado para os propósitos desta periodização. Se, de um lado, o controle estatal dos serviços é um traço comum a todos os períodos, culminando em sua universalização, as ações do mercado, por outro lado, desestabilizam o projeto do Estado em vários momentos, levando à sua reformulação. Pode-se afirmar que o Estado brasileiro tem se valido do correio para afirmar e consolidar a sua presença no território e o mercado, por seu turno, teve papel ativo na transformação do objeto postal em mercadoria e na conversão de um departamento estatal numa empresa postal. $\mathrm{Na}$ atualidade, verifica-se uma convergência interna pela correspondência entre a integração territorial promovida pelo correio e a unificação do mercado nacional. No plano externo, há uma tensão Estado - mercado no conflito pelo uso do território, revelado entre a regulação de um monopólio postal estatal e o lobby das empresas multinacionais de correio para a superação das restrições normativas e ampliação de suas operações no Brasil.

Em todos os períodos, as normas foram relevantes para as ações engendradas pelo Estado e pelo mercado sobre o correio. Parte constituinte do espaço geográfico, a norma está para as ações assim como a forma para os objetos (SANTOS, [1996] 2012b), sendo indispensável para uma análise que contemple tanto a materialidade como a imaterialidade do território. Como assevera Antas Jr. (2005), norma e técnica possuem o mesmo estatuto epistemológico dentro do quadro teórico-conceitual em questão, devendo ser empregados inseparavelmente, bem como objetos e ações. Geograficamente, as normas não podem ser compreendidas deslocadas das outras variáveis do território - a técnica, os objetos, as ações -, que se combinam e se explicam mutuamente. De acordo com M. L. Silveira (2009, p.130), "quando analisamos técnicas, normas e ações, estamos fazendo um esforço para entender a constituição do território, seus usos, isto é, como, onde, por quem, por que, para que o território é usado". No caso do correio brasileiro, o quadro normativo e é um dos elementos mais significativos de uma especificidade nacional.

Nesta proposta, o correio comparece como um elo de integração territorial historicamente determinado. Assim, importa evidenciar o processo pelo qual o território foi gradualmente se integrando por meio dos serviços postais, revelando sua dimensão técnica e política, material e normativa. Neste sentido, o território pode ser considerado como "conexão 
ideal entre espaço e política" (GOTTMANN, [1975] 2012, p.523) e, como se transformam historicamente as formas de poder político e consequentemente o próprio território, também como expressão da relação entre tempo e política. Da multidimensionalidade do território deriva sua potência explicativa, o que exige também uma abordagem metodológica que considere essas dimensões, já que ele pode ser entendido, concomitantemente, como

uma construção militar (um resultado da conquista espacial, que tem de ser
reiterada sempre que contestada) e uma construção política (como área de
exercício de um poder soberano), mas também uma construção econômica
(como suporte de estruturas e atividades produtivas como um mercado) e
uma construção jurídica (que tem de ser legitimada em fóruns adequados de
relacionamento internacional), e ainda uma construção ideológica (que
fundamenta uma identidade social de base espacial e uma psicologia
coletiva) (MORAES, 2005, p.59) Assim, ao considerar o território na história postal brasileira, pretende-se contemplar suas dimensões militar, política, econômica, jurídica e ideológica conforme os diferentes períodos assinalados. Importa ainda considerar o território pelo seu uso (SANTOS, [1993] 2006); não em si mesmo, como se fosse um dado naturalizado, mas pelo uso que dele é feito pelos diferentes agentes que nele coexistem, cooperam e conflitam.

Algumas periodizações da história postal brasileira já foram anteriormente elaboradas, relacionando-se a diferentes enfoques disciplinares. Esses resultados apresentam correspondências e divergências entre si, que vão desde o recorte temporal a ser considerado até os eventos que marcam a transição entre os períodos. Para o efeito de diálogo com este trabalho, consideramos as periodizações realizadas por Rosário (1993), Barros Neto (2004) e a divisão de períodos elaborada pela própria Empresa Brasileira de Correios e Telégrafos (CORREIOS, 2016). Esses resultados foram organizados numa linha do tempo de 1500 até os dias atuais, contemplando as três periodizações apresentadas mais a nossa proposta, segundo os autores e a duração dos períodos (Organograma 1). Ressalte-se o encurtamento da duração dos períodos como uma tendência geral, com o período recente um pouco mais longo que os imediatamente anteriores. 


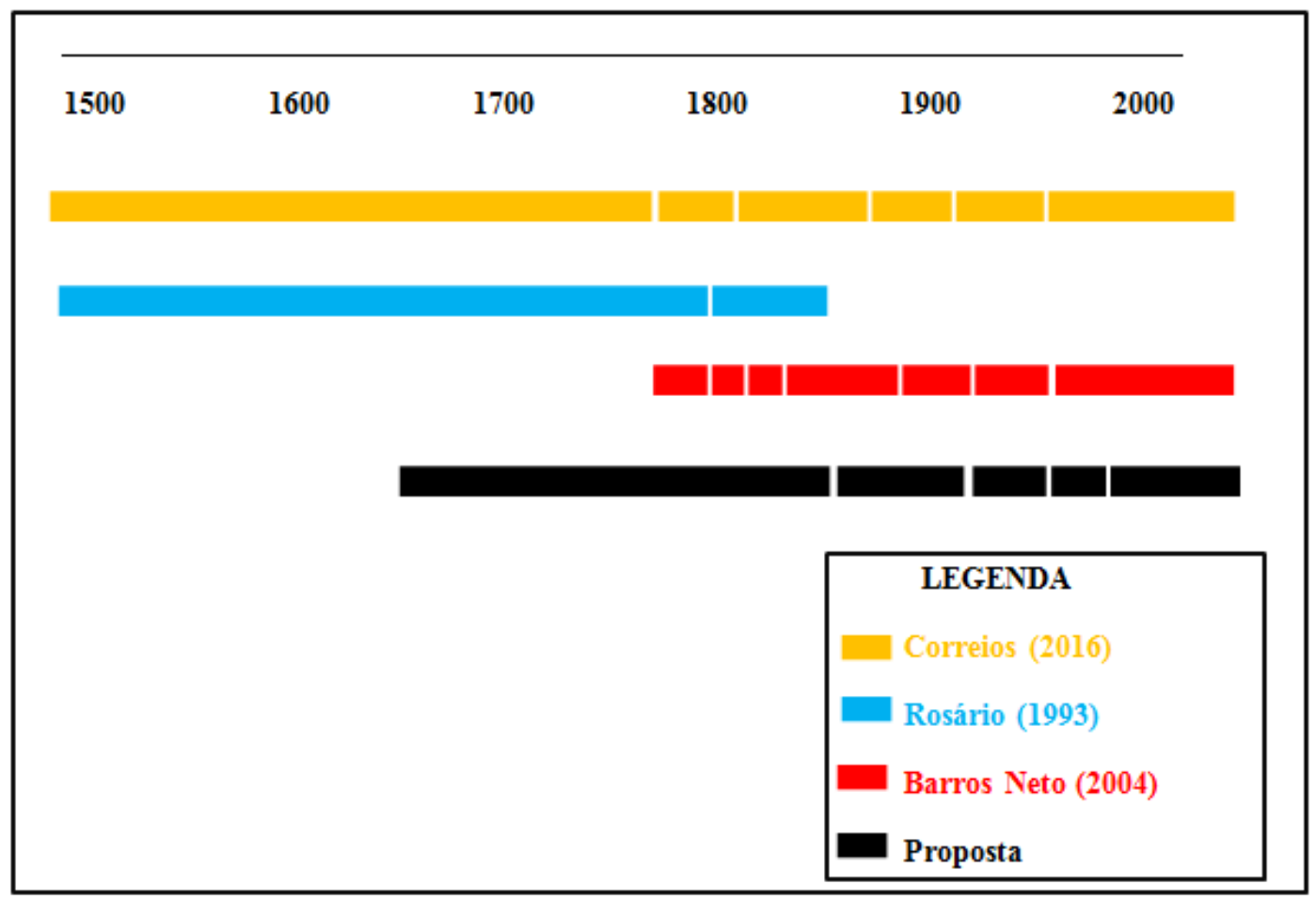

Organograma 1 - Linha do tempo (1500-2016) com diferentes periodizações da história postal brasileira segundo os autores e duração dos períodos, 2016.

Fonte: Elaboração própria a partir de revisão bibliográfica.

A ECT apresenta uma divisão da história postal em seis períodos (Correios, 2016), ainda que não faça uma periodização propriamente dita por apresentar antes um relato cronológico de alguns eventos que uma interpretação. Nesse documento, o primeiro período é denominado "das primeiras cartas ao Correio-Mor" e vai de 1500 até 1797; o segundo período é o da "estatização dos serviços e a Administração Geral de Correios", compreendendo do ano de 1798 até 1821; o chamado "período imperial" teria durado de 1822, com a proclamação da independência do Brasil, até 1888; em seguida, a partir da proclamação da república em 1889, teria havido os "Correios na República Velha", que teria durado até 1929; o quinto período corresponde ao Departamento de Correios e Telégrafos (DCT), que dura até 1968; por fim, o período que se estende desde a criação da ECT em 1969 até os dias atuais. Esses períodos, apesar de apresentarem alguma semelhança com a proposta deste trabalho - como os marcos do Correio-Mor, da DCT e da ECT e a duração de alguns deles - estão mais relacionados aos respectivos períodos da história político-administrativa brasileira, a exemplo do Período Colonial, do Período Imperial, da República Velha, etc., que nem sempre se trataram de rupturas significativas na história do correio.

Estudando três séculos e meio da história postal brasileira (1500-1843), Rosário (1993) a divide em apenas dois grandes períodos: o primeiro iria do descobrimento até a 
chegada da família real portuguesa ao Brasil, em 1808; e o segundo, mais curto, da inversão brasileira ${ }^{10}$ até 1843 , com a emissão dos selos olhos-de-boi ${ }^{11}$. O reconhecimento da adoção do selo como um marco da história postal diferencia o estudo de Rosário do anteriormente mencionado, apresentado pelos Correios, e encontra correspondência com a nossa proposta. Já o descobrimento e a vinda da família real para o Brasil como os marcos mais relevantes dos períodos diferencia a proposta em tela do nosso trabalho.

Em seu estudo, Barros Neto (2004) divide a história postal em sete períodos distintos, que são: 1) a criação do correio público, de 1796 até 1808; 2) o governo imperial e as reformas, da chegada da família real até 1822; 3) os correios no Brasil independente, de 1822 ao ano de 1829; 4) a Administração Geral dos Correios, de 1829 a 1889; 5) correios e república, de 1889 a 1930; 6) Estado Novo e correios, até 1968; 7) a empresa de Correios, desde sua criação em 1969 até os dias atuais. Marcadamente uma proposta elaborada sob o paradigma da administração, mescla eventos da história político-administrativa brasileira com a organização interna do correio. Consequentemente, o autor assinala o primeiro período de uma verdadeira história postal brasileira praticamente no início do século XIX, o que se diferencia bastante da nossa proposta. Ainda dá pouca ênfase aos impactos das mudanças técnicas no serviço postal, mesmo valorizando diferentemente o quadro normativo que origina novos arranjos institucionais e administrativos.

Em nossa proposta (Quadro 2), os períodos foram nomeados em conformidade com as diferentes etapas da integração do território nacional, sendo que o primeiro deles teve início em 1663 com a instituição do Correio-Mor no Brasil e se estendeu até meados do século XIX; o denominamos de "o território extravertido e o tempo lento das comunicações postais". O período seguinte assinala o início da integração do território, que vai da adoção do selo postal em 1843 até o ano de 1930. No terceiro período, vigora o projeto geopolítico-militar de integração territorial sob os auspícios do Departamento de Correios e Telégrafos (DCT), estendendo-se até a sua transformação em Empresa Brasileira de Correios e Telégrafos (ECT) em 1969, evento que marca um quarto período na história postal, desta vez de consolidação da integração territorial.

\footnotetext{
${ }^{10} \mathrm{Na}$ história, a chamada inversão brasileira corresponde ao período em que o Brasil passa de simples colônia à condição de sede do governo português, com a chegada da Família Real ao Rio de Janeiro em 1808, acarretando na criação de inúmeras instituições como escolas, bibliotecas, bancos, tribunais, teatros, entre outros.

${ }^{11}$ Olho-de-boi foi a denominação atribuída aos primeiros selos postais emitidos no Brasil.
} 


\begin{tabular}{|c|c|c|c|c|c|c|c|c|c|c|}
\hline \multicolumn{3}{|c|}{ PERÍODO } & \multirow{2}{*}{ ESTADO } & \multirow{2}{*}{ MERCADO } & \multirow{2}{*}{ TERRITÓRIO } & \multirow{2}{*}{ NORMA } & \multirow{2}{*}{ TÉCNICA } & \multirow{2}{*}{ TEMPO } & \multirow{2}{*}{$\begin{array}{c}\text { MEIO } \\
\text { GEOGRÁFICO }\end{array}$} & \multirow{2}{*}{$\begin{array}{c}\text { FUNÇÃO DO } \\
\text { CORREIO }\end{array}$} \\
\hline ORDEM & $\begin{array}{l}\text { VIGËNCIA } \\
\text { (aprox.) }\end{array}$ & MARCO & & & & & & & & \\
\hline $1^{\circ}$ & 1663-1842 & CORREIO-MOR & $\begin{array}{l}\text { prover ligações entre } \\
\text { a metrópole e a } \\
\text { colônia }\end{array}$ & $\begin{array}{l}\text { inexistência do } \\
\text { serviço com fins } \\
\text { comerciais }\end{array}$ & $\begin{array}{c}\text { pontos relativamente } \\
\text { desconectados } \\
\text { entre si }\end{array}$ & $\begin{array}{c}\text { decretos de } \\
\text { instituição do } \\
\text { correio-mor; } \\
\text { Administração Geral } \\
\text { dos Correios }\end{array}$ & $\begin{array}{c}\text { homens/ } \\
\text { animais/ } \\
\text { barco }\end{array}$ & $\begin{array}{l}\text { Muito lento } \\
\text { (meses) }\end{array}$ & NATURAL & $\begin{array}{l}\text { conexão da colônia à } \\
\text { metrópole lusitana/ } \\
\text { comunicação }\end{array}$ \\
\hline $2^{\circ}$ & $1843-1930$ & SELO POSTAL & $\begin{array}{l}\text { organização dos } \\
\text { serviços }\end{array}$ & $\begin{array}{l}\text { mercantilização do } \\
\text { objeto postal }\end{array}$ & $\begin{array}{l}\text { conexão entre cidades } \\
\text { mais importantes }\end{array}$ & $\begin{array}{l}\text { Ministério Indústria, } \\
\text { Viação e Obras } \\
\text { Públicas }\end{array}$ & $\begin{array}{l}\text { navio/ } \\
\text { telégrafo }\end{array}$ & $\begin{array}{c}\text { Lento } \\
\text { (semanas) }\end{array}$ & TÉCNICO & $\begin{array}{l}\text { conexão entre as } \\
\text { principais cidades do país/ } \\
\text { comunicação }\end{array}$ \\
\hline 3은 & 1931-1968 & $\begin{array}{c}\text { Departamento } \\
\text { de Correios e } \\
\text { Telégrafos - } \\
\text { DCT }\end{array}$ & $\begin{array}{l}\text { operação geopolítico- } \\
\text { militar }\end{array}$ & $\begin{array}{l}\text { assalariamento/ } \\
\text { aperfeiçoamento da } \\
\text { mão-de-obra/ } \\
\text { pequenas empresas }\end{array}$ & $\begin{array}{l}\text { conexão da } \\
\text { área core }\end{array}$ & $\begin{array}{l}\text { Ministério Viação e } \\
\text { Obras Públicas }\end{array}$ & $\begin{array}{l}\text { avião/ } \\
\text { ferrovia/ } \\
\text { máquina de } \\
\text { franquear }\end{array}$ & $\begin{array}{l}\text { Rápido } \\
\text { (dias) }\end{array}$ & TÉCNICO & $\begin{array}{l}\text { integração das áreas } \\
\text { mais afastadas à } \\
\text { área core }\end{array}$ \\
\hline $4^{\circ}$ & 1969-1981 & $\begin{array}{l}\text { Empresa } \\
\text { Brasileira de } \\
\text { Correios e } \\
\text { Telégrafos - } \\
\text { ECT }\end{array}$ & $\begin{array}{c}\text { ampliação da } \\
\text { presença no território } \\
\text { nacional/ } \\
\text { monopólio } \\
\text { postal }\end{array}$ & $\begin{array}{c}\text { empresa } \\
\text { postal }\end{array}$ & integração nacional & $\begin{array}{l}\text { Ministério das } \\
\text { Comunicações/ } \\
\text { Lei Postal }\end{array}$ & $\begin{array}{l}\text { avião/ } \\
\text { caminhão/ } \\
\text { máquina de } \\
\text { triagem }\end{array}$ & $\begin{array}{l}\text { Muito rápido } \\
\text { (1 dia) }\end{array}$ & TÉCNICO & $\begin{array}{l}\text { integração nacional } \\
\text { completa/ } \\
\text { comunicação e transporte }\end{array}$ \\
\hline $5^{\circ}$ & $\begin{array}{l}\text { 1982-dias } \\
\text { atuais }\end{array}$ & $\begin{array}{l}\text { Serviço de } \\
\text { Encomenda } \\
\text { Expressa - } \\
\text { SEDEX }\end{array}$ & $\begin{array}{c}\text { presença em todo o } \\
\text { território nacional/ } \\
\text { manutenção do } \\
\text { monopólio/ } \\
\text { não privatização }\end{array}$ & $\begin{array}{l}\text { diversificação dos } \\
\text { serviços/ } \\
\text { franquias/ } \\
\text { e-commerce/ } \\
\text { empresas } \\
\text { multinacionais }\end{array}$ & $\begin{array}{c}\text { integração e } \\
\text { diferenciação } \\
\text { (homogeneização/ } \\
\text { heterogeneização)/ } \\
\text { seletividade espacial }\end{array}$ & $\begin{array}{l}\text { Constituição de } \\
1988\end{array}$ & $\begin{array}{c}\text { avião/ } \\
\text { caminhão/ } \\
\text { rastreamento/ } \\
\text { postagem } \\
\text { eletrônica }\end{array}$ & $\begin{array}{l}\text { Expresso } \\
\text { (horas) }\end{array}$ & $\begin{array}{c}\text { TÉCNICO- } \\
\text { CIENTÍFICO- } \\
\text { INFORMACIONAL }\end{array}$ & $\begin{array}{l}\text { integração diferenciada/ } \\
\text { comunicação, transporte e } \\
\text { logística/ } \\
\text { grandes projetos estatais/ } \\
\text { e-commerce }\end{array}$ \\
\hline
\end{tabular}

Quadro 2 - Síntese da proposta de periodização.

Fonte: Elaboração própria, com base na matriz de eventos construída pelo autor. 
É com a criação do SEDEX em 1982 e suas sucessivas transformações, contudo, que o território brasileiro já integrado sofre um processo de diferenciação que se estende até os dias atuais, o quinto período. A vigência dos períodos é apenas uma aproximação das datas dos marcos selecionados dentre os eventos, mas os anos não devem ser tomados rigidamente, já que algumas características de um período podem ser encontrados mesmo sob a prevalência de outro.

Na sequência, cada período será discutido separadamente, revelando a sua coerência interna e os elementos que marcaram suas rupturas e continuidades.

\subsection{Primeiro período (1663-1842): o território extravertido e o tempo lento das comunicações postais}

É somente a partir da conquista portuguesa dos territórios do continente americano que mais tarde seriam chamados de Brasil que se pode falar em correio no país. Não há registros históricos de atividades correlatas de entrega de mensagens ou qualquer tipo de correspondência entre as nações que habitavam as terras brasileiras antes do estabelecimento de assentamentos coloniais. A Carta de Caminha, documento enviado ao rei de Portugal e redigido por Pero Vaz de Caminha, membro da esquadra portuguesa que atracou no litoral da atual Bahia em abril de 1500, é considerada como a primeira correspondência do Brasil. A Carta continha registros das observações realizados pelo próprio Caminha e outros membros da tripulação sobre a terra desconhecida, seus habitantes, sua fauna e flora, seu relevo, entre outros. Tomada pelo seu valor simbólico, o documento é considerado por autores como Rosário (1993), além da própria Empresa Brasileira de Correios e Telégrafos em seu registro institucional autobiográfico (CORREIOS, 2016), como o marco inicial dos serviços postais no Brasil.

A despeito do significado que adquiriu a Carta de Caminha para a história brasileira e, em particular, para a sua história postal, e também pela designação como uma "carta", o documento não utilizou o serviço postal para chegar a Lisboa. Assim, seria cedo falar em correio no Brasil naquela ocasião, serviço que já tinha se desenvolvido em praticamente todo o continente europeu ${ }^{12}$. Passados mais de um século e meio sem o registro da atividade na

\footnotetext{
${ }^{12}$ Desde o século XIII, a família italiana Tasso, de que descende a casa dos príncipes alemães Thurn e Taxis, se dedicava ao transporte de correspondências e detinha o monopólio de uma rede postal que articulava a Europa. Sobre o tema, consulte-se Braudel ([1966] 1983).
} 
colônia, somente em 25 de janeiro ${ }^{13}$ de 1663 é instituído o serviço postal regular no Brasil, data a partir da qual podemos falar do início de uma história postal brasileira. Essa institucionalização se deu por meio da criação do cargo de Correio-Mor da colônia, à época denominado Correio da Capitania do Rio de Janeiro, sendo o primeiro deles o alferes João Cavalheiro Cardozo. Os correios-mores eram cargos hereditários, cujo nomeado tinha a função de organizar e gerir os serviços postais do país. O primeiro correio-mor foi criado em Portugal em 1520 pelo Rei D. Manuel I e ao sétimo deles, Luiz Gomes da Matta ${ }^{14}$ (à ocasião também correio-mor das cartas do mar $^{15}$ ), é atribuído o feito de criação da função no Brasil. A introdução desse elemento novo no país, ou seja, a instituição do correio-mor, assinala o início do primeiro período, que vigorou até meados do século XIX. Contudo, sua criação e controle por um poder externo, a coroa portuguesa, trouxe reverberações internas permanentes.

Uma diferença elementar entre o correio-mor de Portugal e do Brasil era a submissão do segundo ao primeiro, sendo impedido de criar qualquer tipo de serviço postal que não fosse de ligação direta e estrita com Lisboa. Conforme esclarece Rosário (1993, p.32), “o privilégio dos Correios-mores do Reino e das Cartas do Mar no Brasil era restrito ao recebimento pelos seus assistentes das cartas que vinham do exterior e a expedição das cartas que lhe eram entregues para serem enviadas para o exterior, via Portugal", diferentemente do que ocorria em solo lusitano. Desta maneira, o Estado envidava esforços em prover uma ligação exclusiva entre a colônia e a metrópole, indispensável para o envio de ordens e a chegada de informações do mundo colonial.

Apesar da nomeação de sucessivos correios-mores da colônia, durante todo o século XVII o incipiente serviço era prestado somente na ligação precária entre Lisboa e algumas poucas cidades do litoral brasileiro, sem qualquer forma efetiva de articulação entre elas ou com o interior do território. De acordo com Bovo (1997, p.19), "nas regiões interioranas os serviços de correio eram extremamente precários e não existiam companhias apropriadas para tal". Em 1710, o correio-mor Antônio Alves da Costa manifesta interesse em expandir os serviços para as regiões das Minas Gerais e São Paulo, mas o projeto foi abortado vinte anos mais tarde pelo próprio rei $\mathrm{D}$. João $\mathrm{V}$ em correspondência oficial destinada ao Vice-Rei do

\footnotetext{
${ }^{13}$ Dia em que é comemorado o Dia do Carteiro no Brasil.

${ }^{14}$ A família Matta deteve o privilégio de exploração dos serviços postais portugueses por mais de dois séculos, sendo desta casa a maioria dos correios-mores do reino.

${ }^{15} \mathrm{O}$ cargo de correio-mor das cartas do mar foi criado em 1657 pelo rei de Portugal com a finalidade de cuidar do tratamento de correspondências transportadas por via marítima, na ocasião da guerra com a Espanha e a dificuldade de estabelecer ligações por terra. O Correio-Mor do Reino, cargo mais antigo, acabou por unificar e assumir ambas as funções.
} 
Brasil, proibindo definitivamente qualquer ligação para o interior da colônia, como parte de um conjunto de atos de controle realizado pela coroa portuguesa durante o século XVIII com o intuito de restringir a circulação de informações sobre as novas minas de ouro ${ }^{16}$. Não é possível falar propriamente em mercado ${ }^{17}$ nesse período, pela inexistência de um serviço postal com fins comerciais.

No final do século XVIII, foi estabelecida a ligação marítima regular entre o Brasil e Portugal, que reforçou ainda mais o caráter unilateral dos fluxos. A linha marítima passava por capitanias do litoral brasileiro, mas seu destino era o mesmo de sua origem - Portugal, levando e trazendo mensagens e encomendas, conforme explica Rosário (1993, p.37):

A exemplo do Rio de Janeiro e da Bahia, em cujos portos os Paquetes faziam
escala de dois em dois meses, e que integravam a segunda mala da ligação
de Lisboa ao Brasil, as Capitanias do norte do Brasil possuíam mala postal
marítima regular, ambas estabelecidas pelo Alvará de 20 de janeiro de 1798 ,
que igualmente encarregou a Repartição de Marinha de expedir, a cada dois
meses, Paquetes Correios Marítimos para o porto de Assu, servindo as
Capitanias de Pernambuco, Paraíba, Parnaíba, Maranhão, Piauí e Pará, indo
às Salinas e retornando a Portugal. Os paquetes transportavam, além de
correspondências, pequenas encomendas e produtos do País, ficando sujeitos
aos Regulamentos e despachos das alfândegas, sendo o frete regulado pela
Administração do Correio-Geral de Lisboa. Os fluxos do correio eram direcionados exclusivamente para o exterior e de lá também originados caracterizam a extraversão do território neste primeiro período. Deste modo, o território colonial era constituído de pontos relativamente desconectados entre si - algumas cidades no litoral das capitanias - que convergiam para o único portal de acesso ao mundo Portugal (Mapa 1). Analisando o século XVIII, Celso Furtado ([1959] 2007, p.138) observou que "a economia brasileira se apresentava como uma constelação de sistemas em que alguns se articulavam entre si e outros permaneciam praticamente isolados". O mesmo foi observado por Moraes (2005) a respeito do baixo nível de articulação interna das áreas produtivas do território colonial, que se articulavam diretamente aos circuitos do comércio mundial. Somente em 1773 será oficialmente autorizada a primeira comunicação postal terrestre, que se deu por um serviço de estafetas ${ }^{18}$ entre o Rio de Janeiro e São Paulo (CORREIOS, 2016), mas

\footnotetext{
${ }^{16}$ Apesar das proibições, há registros de uma linha clandestina de correio que articulava as cidades do Rio de Janeiro, São Paulo e Mariana (CORREIOS, 2016), manifestação da tensão entre poderes internos e externos ao território.

${ }^{17}$ Há controvérsias sobre falar ou não de mercado no Brasil colonial. Autores como Furtado ([1959] 2007) consideram uma economia escravista e a posterior transição para uma economia de trabalho assalariada. Um mercado capitalista, como o conhecemos hoje, só teria se efetivado a partir do assalariamento da mão-de-obra e, entre outras, da Lei de Terras de 1850, que transformou a terra em mercadoria.

${ }^{18}$ Correio a cavalo.
} 
que não significou a superação do território extravertido, reforçando os fluxos externos a partir do Rio de Janeiro.

No final do século XVIII, a coroa portuguesa extinguiu o cargo de correio-mor e reivindicou para si a administração dos serviços postais, estatização que afetou também o Brasil. Conforme se expandiam as relações comerciais e industriais de Portugal, mais se intensificava a insuficiência dos serviços postais, ainda que os detentores do ofício tenham se empenhado para acompanhar o rápido desenvolvimento das comunicações em todo o mundo. No Brasil, foi iniciado um novo processo de organização que resultou na criação de uma Administração Geral dos Correios; inauguração de uma agência postal no interior, na cidade de Campos dos Goytacazes-RJ; estabelecimento do cálculo dos portes das correspondências com base no peso e na distância percorrida para a entrega (CORREIOS, 2016).

Em 1808, com a chegada da família real portuguesa ao Brasil e a mudança da sede do governo de Lisboa para o Rio de Janeiro ${ }^{19}$, é instituído o primeiro regulamento postal brasileiro, que criou várias normas para a execução dos serviços. No mesmo ano, a ligação marítima do serviço postal deixa de ser efetuada via Lisboa e passa a ligar diretamente a Londres. Mais tarde, a correspondência recebida por D. Pedro $\mathrm{I}^{20}$ e enviada da Imperatriz Leopoldina, na ocasião da proclamação da independência do Brasil em 1822, é também considerada pela historiografia como um evento importante da história postal. Contudo, à semelhança da Carta de Caminha, sua relevância simbólica é muito maior do que qualquer impacto ou transformação que tenha ocasionado no correio da época.

O Regulamento à Administração Geral dos Correios, decreto de 5 de março de 1829, foi o instrumento normativo mais importante do período, pois permitiu unificar uma série de normas de diferentes idades que haviam sido promulgadas pelos extintos correios-mores. Desta maneira, apesar dos novos elementos que surgiram nessa fase, o conjunto de normas instituídas pelo documento não foram capazes de romper com as condições pré-existentes e criar um novo período, pois reforçaram aquelas velhas características já apontadas, como a prevalência da extroversão. O texto, reproduzido na íntegra por Rosário (1993), versa sobre diferentes assuntos, desde o salário dos funcionários de correio até procedimentos a serem adotados no transporte das correspondências.

\footnotetext{
${ }^{19}$ A família real estava fugindo da invasão de Portugal por tropas de Napoleão.

${ }^{20}$ A correspondência fora entregue pelo mensageiro Paulo Bregaro, considerado o patrono dos carteiros no Brasil.
} 


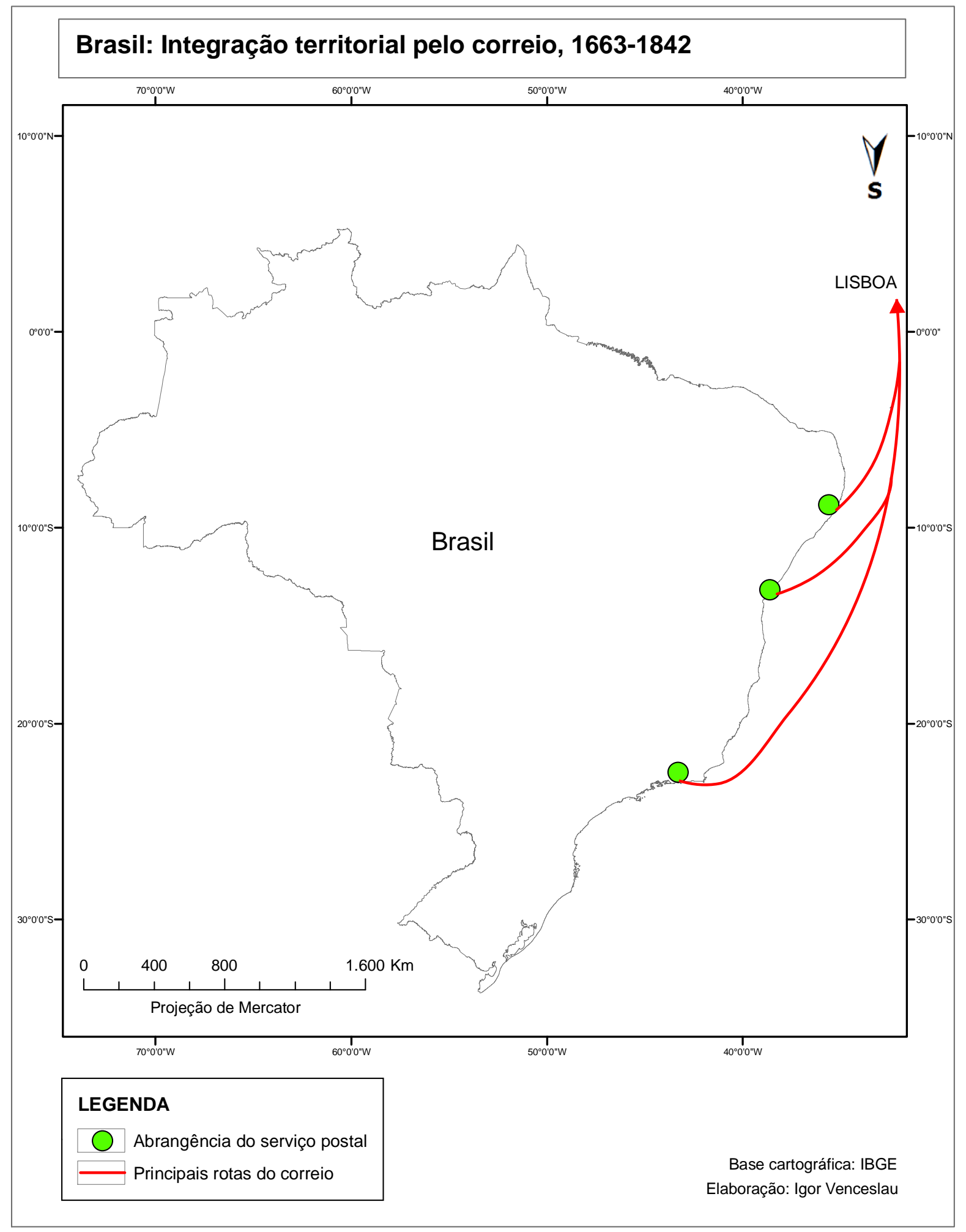

Mapa 1 - Brasil $^{21}$ : integração territorial pelo correio, 1663-1842.

Fonte: Elaboração própria a partir de revisão bibliográfica e matriz de eventos.

${ }^{21} \mathrm{O}$ mapa foi elaborado considerando a forma atual do território brasileiro. Essa foi uma escolha consciente, cujo propósito é permitir a comparação com mapas elaborados para outros períodos, como será feito ao final do capítulo, sem prejuízo para a compreensão de cada um deles separadamente. 
As técnicas utilizadas para o transporte das malas de correio também estão regulamentas no documento, dispondo no artigo 88 que "para a conducção das malas por terra, haverá os Correios a pé, que forem necessários, nomeados, e assalariados pelos Administradores e, por elles pagos mensalmente, se não convier antes fazer as conducções por arrematação". Desta maneira, as correspondências e pequenas encomendas eram transportadas por muitos homens a pé, que faziam trechos entre uma cidade ou vila e outra, aumentando a lentidão das entregas das correspondências que chegavam pelos barcos. $\mathrm{O}$ uso de animais como o cavalo para o transporte de malas, mais rápido porém mais caro, já largamente utilizado na Europa ${ }^{22}$, somente servia à linha Rio de Janeiro-São Paulo e eventualmente em algum outro trecho. Em visita ao país, o inglês R. Walsh comentava em seu livro Notices of Brazil de 1830, trecho traduzido por Rosário (1993, p.76):

A mala postal é despachada do Rio e, em cada dez dias, para as diferentes localidades do interior. Não existem, como é natural, os chamados carros de posta, mas frequentemente encontrei o correio pelas estradas. A mala é transportada por dois negros que levam um porta-manta às costas e uma saca à mão. Andam a pé, fazendo uma légua ou quatro milhas por hora.

Por certo, ainda não havia no Brasil as condições técnicas - estradas melhoradas, carros movidos por velozes cavalos dedicados ao serviço postal, etc. - nem as condições políticas - interesse por parte da administração da colônia, posteriormente vice-Reino e Império - para o surgimento de um correio mais veloz e regular. O tempo que as correspondências levavam para chegar ao destino é uma manifestação dos atributos técnicos e políticos do período, sendo que o prazo de entrega de uma carta ou encomenda era contado em meses, considerando todo o percurso feito por barco a vela, animais, homens a pé, entre outras formas. O tempo muito lento do correio não permitia uma maior regularidade, tampouco previsão sobre a entrega. Todas essas formas de transporte eram empregadas apenas para que as correspondências fossem levadas entre uma cidade e outra, pois a entrega domiciliar só começou a ser realizada no Brasil a partir de $1835^{23}$.

A lentidão do correio, aliada às técnicas pouco sofisticadas para o transporte de correspondências, assinalam um período que se inscreve num meio natural. Os fenômenos climáticos, a vazão de rios, a direção dos eventos e outras intempéries tinham forte influência sobre o fluxo das correspondências, mais importantes do que qualquer objeto criado pelo

\footnotetext{
${ }^{22}$ Em 1290, Amadeu Tasso já tinha organizado o sistema de entrega de correio a cavalo na Itália e outros países europeus (BRAUDEL, [1966] 1983).

${ }^{23}$ Até essa data, as cartas e encomendas eram retiradas na própria agência de correio pelo destinatário, que também realizava o pagamento pelo serviço postal no lugar do remetente, situação que será alterada no período seguinte. Vale ressaltar que em 1835 a entrega domiciliar tem início em alguns bairros do Rio de Janeiro e aos poucos foi sendo criado localmente o serviço de entrega em outras cidades.
} 
trabalho humano que pudesse contornar essas condições. Essa importância pode ser comprovada pela centralidade conferida aos fenômenos da (primeira) natureza em diversas passagens do Regulamento à Administração Geral dos Correios:

Art. $95^{\circ}$ - Os conductores de malas sahirão das casas dos Correios a que pertencerem impreterivelmente às horas que estiverem marcadas, e andarão de modo que cheguem aos lugares do seu destino no dia e hora, que estiver determinada. Quando se demorarem por mais de quatro horas, além do tempo que estiver marcado, e não mostrarem que o fizerem por causa attendivel, que não poderam vencer, como por motivo de grandes chuvas, enchentes de rios, ou moléstia, se lhes descontará no seu salario o que corresponder ás horas da sua demora; e se reincidirem, serão despedidos.

Art. $110^{\circ}$ - Os Commandantes levarão as malas no sítio mais bem resguardado da câmara, sempre lestes, para serem lançados ao mar em tempo de guerra.

Art. $111^{\circ}$ - Seguirão o rumo mais conhecido, fazendo sempre a maior força de vela, que permitir a embarcação; e nunca mudarão o rumo, senão obrigados de temporal, ou inimigo (Grifos nossos).

As condições técnicas e políticas do período influenciaram profundamente o cotidiano do correio. Os atrasos e desvios de correspondências eram devidos a uma determinação dos ritmos e tempos da natureza sobre as técnicas utilizadas, marcando as formas de transporte e os prazos de entrega. Da mesma maneira, o correio também estava susceptível a mudanças causadas por condições de guerra e presença de inimigos durante o percurso, principalmente no caso da navegação marítima. À instabilidade de um meio natural somava-se a insegurança do território colonial.

Pode-se dizer, ainda, que a geografia do correio brasileiro dos séculos XVII, XVIII e parte do XIX revela aquilo que Moraes (2005) denominou de "fundos territoriais", ou seja, a prevalência de áreas ainda não utilizadas pelo colonizador e pouco conhecidas, que se expressam na vastidão do território que não dispunha do serviço postal. Aqueles pontos conectados a uma rede postal incipiente seriam o que o autor considera como "zonas de difusão", assentamentos originais que servem de base para expansões posteriores. De fato, a difusão dos serviços postais pelo Brasil irá revelar uma diferença entre esses núcleos iniciais e o restante do território, demonstrando a relevância das formas e usos pretéritos do território para as ações do presente.

Nesse primeiro período, a função desempenhada pelo correio era claramente de assegurar uma comunicação minimamente possível, ainda que num tempo muito lento e sob os ritmos de um meio natural, entre a colônia do Brasil e a metrópole lusitana, utilizando técnicas pouco sofisticadas e sob o aparato normativo de um Estado que inviabilizava uma 
política de integração interna, priorizando fluxos externos e produzindo um território extravertido. À cartografia dos fluxos de matérias-primas exportadas, somava-se os fluxos de correspondências, que seguiam na mesma direção. Assim, o correio reforçou, nesse período, a condição de dependência da formação socioespacial brasileira, dado o uso do território voltado para fins externos.

\subsection{Segundo período (1843-1930): do selo ao telégrafo - o início da integração do território}

No ano de 1840, foi criado por Rowland Hill, na Inglaterra, o primeiro selo postal adesivo, o Penny Black, parte da chamada Reforma Postal Inglesa que posteriormente afetaria os correios de todo o mundo. Com essa invenção, o pagamento da correspondência passou a ser feito pelo remente e não pelo destinatário, como ocorria até então, tendo o selo uma função de comprovante desse pagamento. Outra novidade do selo foi desconsiderar a distância no cálculo do preço das correspondências, adotando tarifação única conforme a variável peso. Com isso, somente na Inglaterra o volume de correspondências saltou de 76 para 169 milhões em um ano (MATTELART, 1994, p.21).

O Brasil foi o segundo país ${ }^{24}$ a adotar o selo postal, logo após a Inglaterra ${ }^{25}$, em 1843, emitindo os chamados Olho-de-Boi ${ }^{26}$ nos valores de 30, 60 e 90 réis. O país entrava numa fase caracterizada por altas taxas de crescimento econômico, que se estenderia por toda a segunda metade do século XIX (FURTADO, [1959] 2007), com fortes repercussões sobre o correio. Conforme consta no artigo 16 do Decreto $\mathrm{n}^{\circ} 254$ de 29 de novembro de 1842, reproduzido na íntegra por Rosário (1993), “os portes serão pagos adiantados, e em papel sellado, na forma, e com as excepções, que serão declarados em outros Regulamentos". Na tentativa de organizar os serviços postais e inserir o Brasil na modernidade, outros decretos

\footnotetext{
${ }^{24}$ A título de comparação, os Estados Unidos somente realizaram uma reforma postal à inglesa no ano de 1847 , quatro anos após o Brasil; a França, em 1848 (MATTELART, 1994).

${ }^{25}$ Após a proclamação da independência brasileira, os contratos celebrados entre Inglaterra e Portugal foram transferidos para o Brasil, incluindo acordos comerciais que privilegiavam a relação com os ingleses (FURTADO, [1959] 2007). Desta maneira, a linha postal marítima que já havia sido transferida de Lisboa para Londres no final do período anterior seria apenas uma das manifestações das estreitas relações entre os dois países durante o século XIX.

${ }^{26}$ Posteriormente, foram adicionadas novas emissões de selos: os "inclinados", em 1845; em 1866, os selos passaram a ser picotados e a representar a efígie de D. Pedro II; a partir de 1878, os selos começaram a ser emitidos em cores, sendo os primeiros deles chamados "auriverdes"; em 1900, pela primeira vez, os selos estamparam figuras humanas diferentes da efígie do imperador, em alusão ao quarto centenário do Brasil; mais recentemente, os Correios passaram a emitir selos personalizados, com a imagem solicitada pelo cliente, inclusive fotografias (2000); no mesmo ano, o Brasil foi pioneiro no lançamento do primeiro selo do mundo a possuir odor, numa coleção filatélica sobre prevenção de incêndios em florestas tropicais (CORREOS, 2016).
} 
foram assinados pelo governo imperial, contendo disposições para a padronização dos serviços. Ainda sobre a carta, além da aposição do selo no ato da postagem, outros elementos foram considerados como obrigatórios. O artigo 15 do decreto $\mathrm{n}^{\mathrm{o}} 255$ de 29 de novembro de 1842 institui que "no sobrescripto da carta, e mais papeis, será declarada a rua, o número da casa, e andar della, em que more a pessoa, a quem deve ser entregue; e quando taes declarações não sejão feitas, a carta, ou papel será levado à lista geral, como actualmente se pratica". Essas novas exigências contribuíram para aumentar o grau de racionalização das ações do correio, e tornando o objeto postal mais complexo. Para Barros Neto (2004, p.39), “o segundo Império pode ser caracterizado como o período de expansão e modernização dos serviços de comunicações no Brasil”, pois além de reformas no correio, houve também a introdução do telefone e do telégrafo. Todos esses novos objetos foram incorporados desde vetores externos ao território, desestabilizando a velha ordem interna do período anterior.

A criação do selo postal é um marco importante na história do correio, pois assinala a transformação do objeto postal em mercadoria. Se para Gertel (1991) o objeto postal somente se transformou em mercadoria, no Brasil, com a criação da Empresa Brasileira de Correios e Telégrafos (vide item 1.5), argumentamos que as bases para essa mercantilização são bastante anteriores, remontando à adoção do selo. Na esteira de um sistema econômico que abandonava gradativamente o trabalho escravo para incorporar o assalariamento da mão-deobra e transformava a terra em mercadoria (Lei de Terras de 1850), o mercado teve forte influência sobre esse processo de mercantilização do objeto postal. Anteriormente, o pagamento do porte da correspondência pelo destinatário não era obrigatório nem padronizado em todos os lugares e, no caso de recusa ao recebimento, ninguém pagava ao correio pelo serviço prestado. A antecipação do pagamento permitiu assegurar a rentabilidade do empreendimento; se antes o mais importante, ou seja, a correspondência, é o que vinha primeiro, agora é o pagamento da mercadoria que antecede e autoriza qualquer tipo de ação. O selo pode ser compreendido como uma nova técnica para a circulação postal, mas também como uma nova política de reprodução da mercadoria.

De acordo com Gertel (1991, p.112-113), “o selo postal abre novas perspectivas para os correios e para o seu desenvolvimento internacional, de modo a se garantir a liberdade de trânsito da correspondência". Consequentemente, no ano de 1861 foram promulgadas as primeiras convenções internacionais para regulamentar as trocas de correspondências entre os Estados. Esse novo aparato normativo e a necessidade de sua atualização e fiscalização levou, mais tarde, à fundação da União Internacional Telegráfica, em 1865, e da União Geral dos Correios - no ano de 1874, em Berna, Suíça. Três anos mais tarde, o Brasil aderiu ao tratado, 
num acordo celebrado em Berna, sendo essa a mais antiga participação do Brasil em organizações internacionais (MONTGOMERY, 2002). Desde o Congresso de Paris de 1879, a União Geral dos Correios passou a se chamar União Postal Universal (UPU). De acordo com Mattelart (1994), a UPU teve por objetivo primeiro harmonizar as tarifas postais internacionais, já possível a partir da invenção do selo algumas décadas antes, e oficializar o reconhecimento de um princípio básico do correio - a inviolabilidade da correspondência.

Se na escala internacional o correio experimentava uma profunda reestruturação, internamente o Estado brasileiro assume a atribuição de organização dos serviços postais, num país que passava por importantes transformações políticas - do império à república. Para assegurar o mínimo de unidade, era necessário manter as ligações externas, mas também criar condições para a ampliação dos serviços no interior do país. Durante o segundo período, o correio ficou subordinado a diversas repartições do Estado: a partir de 1861, integrou a Secretaria dos Negócios da Agricultura, Comércio e Obras Públicas; após a proclamação da República, a chamada Repartição Postal ficou subordinada ao Ministério da Instrução Pública, Correios e Telégrafos e, posteriormente, ao Ministério da Indústria, Viação e Obras Públicas; a partir de 1909, vinculado ao Ministério da Indústria, Viação e Obras Públicas (CORREIOS, 2016). Do mesmo modo, a organização em voga atingiu também os trabalhadores que rapidamente se assalariavam e cresciam em número; o Decreto nº 255 de 1842 dispôs que:

Art. 12 - Haverá numero de Carteiros necessários para entregarem as cartas nas casas das pessoas, a quem o devem ser, e serão nomeados pelo Administrador do Correio, ou quem suas vezes fizer, sob sua responsabilidade.

Art. 19 - Sahirão os Carteiros a fazer entrega em horas certas, como seis, dez, duas, aonde, e quando a affluencia dos Correios o exigir. Entre as sahidas ordinárias dos Carteiros poderão haver extraordinárias; se houver assignantes, que queirão receber a sua correspondência logo que chegar ao Correio.

Como aponta Barros Neto (2004), é também na segunda metade do século XIX que tem início uma organização na triagem das correspondências, que passaram a seguir em malas identificadas por rótulos de destino como, por exemplo, "capital", "trânsito", "agência", etc. Se o Estado continua a assumir, nesse período, a prerrogativa de prestação dos serviços postais e reorganizando todo o correio, o mercado transformou esse mesmo serviço numa mercadoria, além de contribuir com o assalariamento da mão-de-obra.

Juntamente com o selo, o telégrafo também foi uma invenção que marcou o início de um novo período. Criado nos Estados Unidos por Samuel Morse em 1840, o novo objeto técnico começou a ser utilizado no Brasil no ano de 1852, sob a influência dos ingleses e seus 
interesses em utilizá-lo para auxiliar no combate ao tráfego de escravos no Atlântico. A primeira ligação oficial ocorreu entre o Quartel-General do Exército, no Rio de Janeiro, e a residência imperial da Quinta da Boa Vista (CORREIOS, 2016). Posteriormente, foram criadas linhas que ligavam a capital do império à cidade de Petrópolis e, mais tarde, por cabos submarinos, a Salvador, Recife e Belém. De Recife, os cabos alcançaram o arquipélago de Fernando de Noronha, Cabo Verde, Ilhas Madeira e, enfim, a Europa.

O telégrafo permitiu a instantaneidade na transmissão de informações e, como era assumido por algumas companhias privadas, sofreu historicamente um tratamento distinto do correio. Tanto que em muitos países, incluindo o Brasil, as repartições responsáveis continuam a se chamar "correio e telégrafo", e a partir de então os dois serviços foram considerados separadamente. Malgrado a rapidez e a instantaneidade proporcionadas pelo telégrafo, o correio continuava relativamente lento, com a diminuição dos prazos de entrega de meses para algumas semanas.

\begin{tabular}{|c|c|c|c|c|c|c|c|c|c|c|c|}
\hline $\begin{array}{l}\text { ANO DE } 1809 \\
\text { MESES }\end{array}$ & \multicolumn{5}{|c|}{$\begin{array}{l}\text { Para MINAS } \\
\text { Todas as terças-feiras }\end{array}$} & \multicolumn{3}{|c|}{$\begin{array}{l}\text { Para CAMPOS } \\
\text { Às quartas-feiras } \\
\text { de } 15 \text { em } 15 \text { dias }\end{array}$} & \multicolumn{3}{|c|}{$\begin{array}{l}\text { Para SÃO PAULO } \\
\text { Aos sábados } \\
\text { de } 15 \text { em } 15 \text { dias }\end{array}$} \\
\hline JANEIRO & 3 & 10 & 17 & 24 & 31 & 4 & 18 & & 7 & 21 & \\
\hline FEVEREIRO & 7 & 14 & 21 & 28 & & 1 & 15 & & 4 & 18 & \\
\hline MARÇO & 7 & 14 & 21 & 28 & & 1 & 15 & 29 & 4 & 18 & \\
\hline ABRIL & 4 & 11 & 18 & 25 & & 12 & 26 & & 1 & 15 & 29 \\
\hline MAIO & 2 & 9 & 16 & 23 & 30 & 10 & 24 & & 13 & 27 & \\
\hline JUNHO & 6 & 13 & 20 & 27 & & 7 & 21 & & 10 & 24 & \\
\hline JULHO & 4 & 11 & 18 & 25 & & 5 & 19 & & 8 & 22 & \\
\hline AGOSTO & 1 & 8 & 15 & 22 & 29 & 2 & 16 & 30 & 5 & 19 & \\
\hline SETEMBRO & 5 & 12 & 19 & 26 & & 13 & 27 & & 2 & 16 & 30 \\
\hline OUTUBRO & 3 & 10 & 17 & 24 & 31 & 11 & 25 & & 14 & 28 & \\
\hline NOVEMBRO & 7 & 14 & 21 & 28 & & 8 & 22 & & 11 & 15 & \\
\hline DEZEMBRO & 5 & 12 & 19 & 26 & & 6 & 20 & & 9 & 23 & \\
\hline $\begin{array}{l}\text { HORÁRIO } \\
\text { DAS PARTIDAS }\end{array}$ & \multicolumn{5}{|c|}{$\begin{array}{l}\text { Verão - } 6 \text { da tarde } \\
\text { Inverno - } 5 \text { da tarde }\end{array}$} & \multicolumn{3}{|c|}{10 da manhã } & \multicolumn{3}{|c|}{5 da tarde } \\
\hline
\end{tabular}

Quadro 3 - Dias e horários de partida das malas postais do Rio de Janeiro para o interior do Brasil, em 1809. Fonte: Adaptado de Rosário (1993).

O telégrafo servia para a comunicação de algumas mensagens curtas e para algumas cidades mais destacadas do ponto de vista econômico e político. O correio tradicional continuava importante para o transporte de correspondências de todos os tipos e pequenas encomendas, alcançado maior número de lugares (Quadro 3). No conflito entre o velho e o 
novo, a rapidez também se fez seletiva no território, notadamente naqueles lugares dotados de condições técnicas adequadas. Conforme o progresso técnico, os barcos a vela foram cedendo lugar aos navios a vapor, mais velozes, que encurtaram o tempo de viagens intercontinentais. No entanto, como foi revelado por Mattelart (1994), a navegação marítima a vapor para o transporte postal só foi assegurada nas linhas intercontinentais graças aos constantes incentivos do Estado em diversos países, como Inglaterra, França e Estados Unidos.

O território brasileiro testemunhou, nesse período, uma conexão interna entre as cidades mais importantes - era o início de um processo de integração territorial pelo correio (Mapa 2). Foram criadas algumas agências no interior, bem como constituídas linhas postais regulares entre o Rio de Janeiro e as capitais de províncias, além das linhas telegráficas. Algumas delas já haviam sido regulamentadas no início do século XIX, como as que partiam da cidade do Rio de Janeiro, então capital imperial, rumo às direções oeste - São Paulo, norte - Minas Gerais e nordeste - Campos dos Goytacazes, embora muitas somente foram efetivadas algumas décadas depois.

Apesar do início de uma integração territorial, reforça-se ao longo do litoral brasileiro a concentração da população, dos principais núcleos urbanos e, consequentemente, dos serviços postais. A exceção é feita para Minas Gerais, onde a atividade econômica regional justificava a criação de linhas postais regulares, que correspondiam aos mesmos caminhos por onde era escoado o ouro e demais metais preciosos rumo ao porto na Baia de Guanabara. Aqui mais uma vez é revelado que a historia do correio não pode ser compreendida apartada da história do território brasileiro, cujo peso dessas localizações irá influenciar decisivamente sobre a localização dos serviços e a diferenciação territorial dos períodos posteriores.

Mesmo com o início de uma integração interna a partir da independência política, observa-se que o Brasil enfrentava os desafios de um "Estado territorial num contexto periférico" (MORAES, 2005), pois a elaboração de um projeto nacional era limitada pela influência externa - principalmente da Inglaterra, no caso brasileiro - e pela inserção do país na divisão internacional do trabalho em condição de subordinação, cujas consequências para o correio foram a permanência de uma exclusividade europeia na direção dos fluxos internacionais e a conformação de uma dependência tecnológica dos países centrais. 


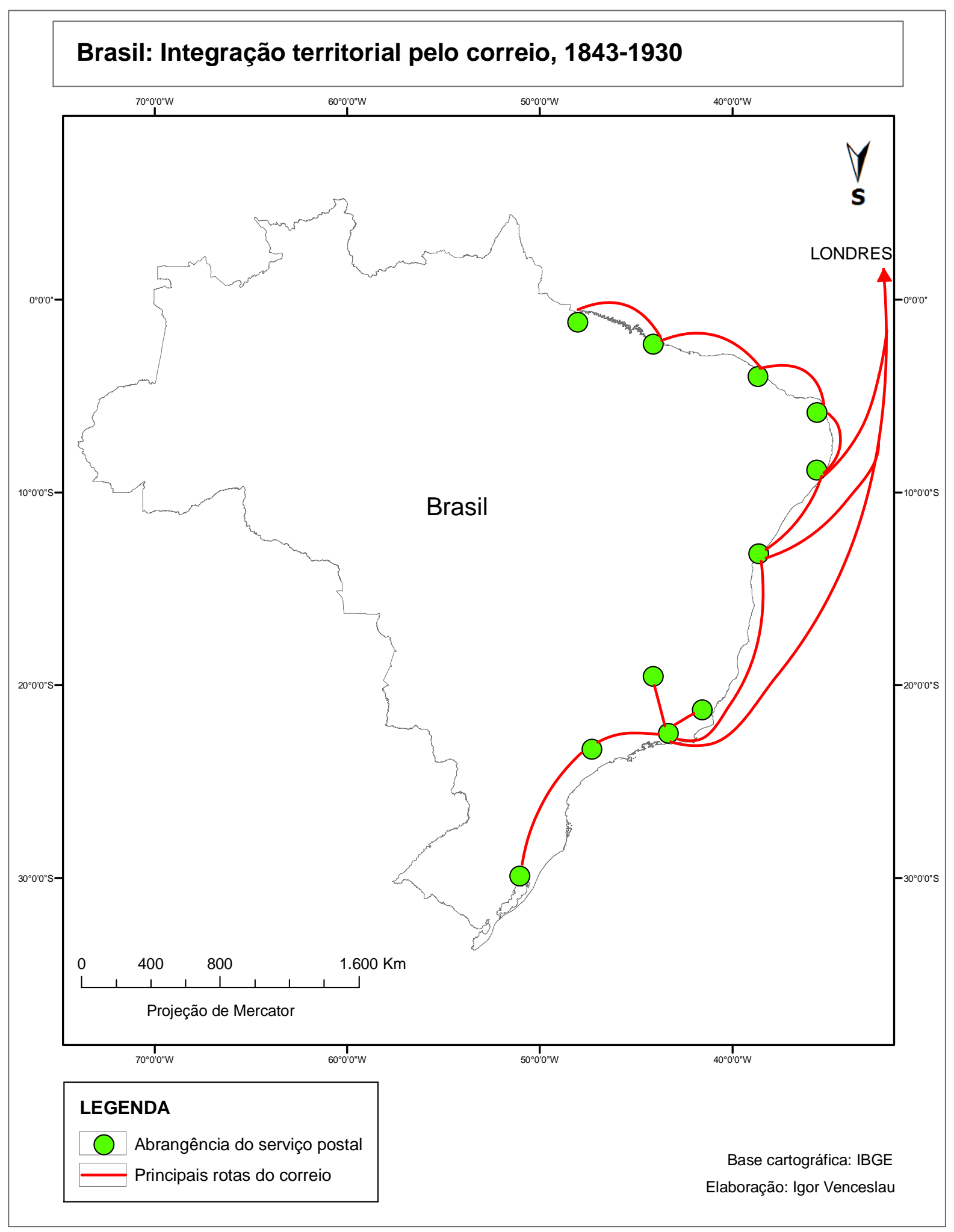

Mapa 2 - Brasil $^{27}$ : integração territorial pelo correio, 1843-1930.

Fonte: Elaboração própria a partir de revisão bibliográfica e matriz de eventos.

\footnotetext{
${ }^{27}$ Assim como assinalado em nota anterior, este mapa não corresponde exatamente aos limites territoriais brasileiros no período apresentado, mas optou-se por manter a forma atual para garantir a comparação com outros mapas.
} 
Assim, o correio passa a agir sobre um meio técnico, dado o grau de artificialização proporcionado pelos novos objetos que asseguravam a mediação das ações de diferentes agentes, permitindo uma aceleração no tempo de circulação postal até então desconhecida. Aqueles constrangimentos e ritmos da natureza pouco a pouco iam sendo ultrapassados pela navegação a vapor e pela telegrafia. Destarte, a função do correio nesse segundo período passa a ser de conexão entre as principais cidades do país, perpetuando seu papel na comunicação. A formação socioespacial brasileira reproduz ordens e convenções externas, assimilando rapidamente as modernizações, ao mesmo tempo em que cria as condições para uma articulação interna. Novos usos do território foram possíveis graças à instantaneidade do telégrafo e ao encurtamento do tempo pela navegação a vapor. O correio, por sua vez, desempenhou um papel ativo nesse processo.

\subsection{Terceiro período (1931-1968): o Departamento de Correios e Telégrafos e o projeto geopolítico de integração territorial}

Desde o início do século XX, o correio brasileiro começava a conhecer os progressos técnicos que iriam se consolidar e alterar substancialmente o tempo da circulação de objetos postais. $\mathrm{O}$ primeiro deles foi a introdução da máquina de franquear correspondências ${ }^{28}$, em 1924, que superou o selo postal adesivo pela possibilidade de imprimir estampas sobre os envelopes de correspondências agrupadas, dispensando a necessidade de aposição manual e acelerando muito o processo na postagem. Essa nova tecnologia de franqueamento é empregada até os dias atuais, embora o selo (velho?) ainda seja largamente utilizado.

Outro progresso técnico que impactou os serviços do correio foi a invenção do avião. O transporte aéreo para o serviço postal começou com testes no país em 1921 e culminou com a primeira mala aérea transportada quatro anos mais tarde, pela empresa francesa Compagnie Genérale d'Enterprises Aéronautiques (CGA). Apesar da censura postal aplicada na Europa durante a I Guerra Mundial (1914-1918), os correios se beneficiaram dos avanços tecnológicos da corrida militar, entre eles o uso de aeronaves. Em 1927, teve início o transporte regular de correspondência via aérea entre a América do Sul e a Europa, passando pelo Brasil - saindo de Santiago do Chile com destino a Paris, com escalas em Buenos Aires, Rio de Janeiro, Recife, Natal, Dacar, Casablanca, Barcelona e Toulouse. O piloto e escritor de literatura francês Antoine de Saint-Exupéry (1900-1944) aborda, em seu primeiro livro,

\footnotetext{
${ }^{28}$ As máquinas utilizadas no Brasil nesse período eram importadas da Universal Postal Frankess, de Londres (CORREIOS, 2016).
} 
Courrier Sud, de 1929, a saga do correio aéreo da linha França-América do Sul, em que ele mesmo foi piloto por vários anos. Numa passagem, revela o imperativo pela velocidade:

(...) para que, apesar das tempestades, das brumas, das ventanias, apesar das mil armadilhas da válvula, do basculador, da matéria, os expressos, comboios, cargueiros e vapores, sejam atingidos, distanciados, superados! E para alcançar, num tempo recorde, Buenos Aires ou Santiago do Chile... (SAINT-EXUPÉRY, [1929] 1966, p.9).

A passagem anuncia uma revolução tecnológica no início do século $\mathrm{XX}$, quando os objetos tentavam não somente vencer as intempéries do meio natural como também superar as antigas invenções do século XIX, agora já tornadas obsoletas e lentas. O avião significou, assim, a superação definitiva do navio a vapor. Era o despontar de uma nova fase para o correio.

Internamente, o Brasil passava por mudanças políticas importantes. O pacto de poderes da República Velha dava sinais de esgotamento, ao mesmo tempo em que o país buscava uma saída para os problemas econômicos gerados a partir da queda das exportações de café com o crash da bolsa de Nova York em 1929. Com o golpe de Estado deflagrado na chamada Revolução de 30, o governo é assumido por Getúlio Vargas, que a partir de então trará profundas transformações para a organização interna do país. Nesse contexto de transformações técnicas e políticas foi criado, em 1931, o DCT, pela fusão dos extintos Direção-Geral dos Correios com a Repartição-Geral dos Telégrafos, ambos subordinados ao Ministério da Viação e Obras Públicas, com sede no Rio de Janeiro. A partir desse momento, as Administrações dos Correios, herança do século anterior cuja função era gerir os serviços nos respectivos estados, passaram à denominação de Diretorias Regionais ${ }^{29}$ (CORREIOS, 2016).

O Brasil passava por um período de modernização, no qual se buscava elaborar um projeto integrador do país em substituição às velhas heranças regionais. Nesse contexto, o Estado se ocupava de "reorganizar e ocupar o território, dotá-lo de novos equipamentos e sistemas de engenharia, conectar suas partes com estradas e sistemas de comunicação" (MORAES, 2005, p.97). Tornando o correio parte dessa política de rápida integração territorial, as ações estatais impulsionaram a difusão do correio no país, consolidando-o nas regiões onde os serviços postais foram inicialmente introduzidos e estendendo-o até as áreas de fronteira. O papel do transporte aéreo no projeto geopolítico de integração territorial das primeiras décadas do século XX foi também estudado por Gallo (2006).

\footnotetext{
${ }^{29}$ As Diretorias Regionais são mantidas até os dias atuais.
} 


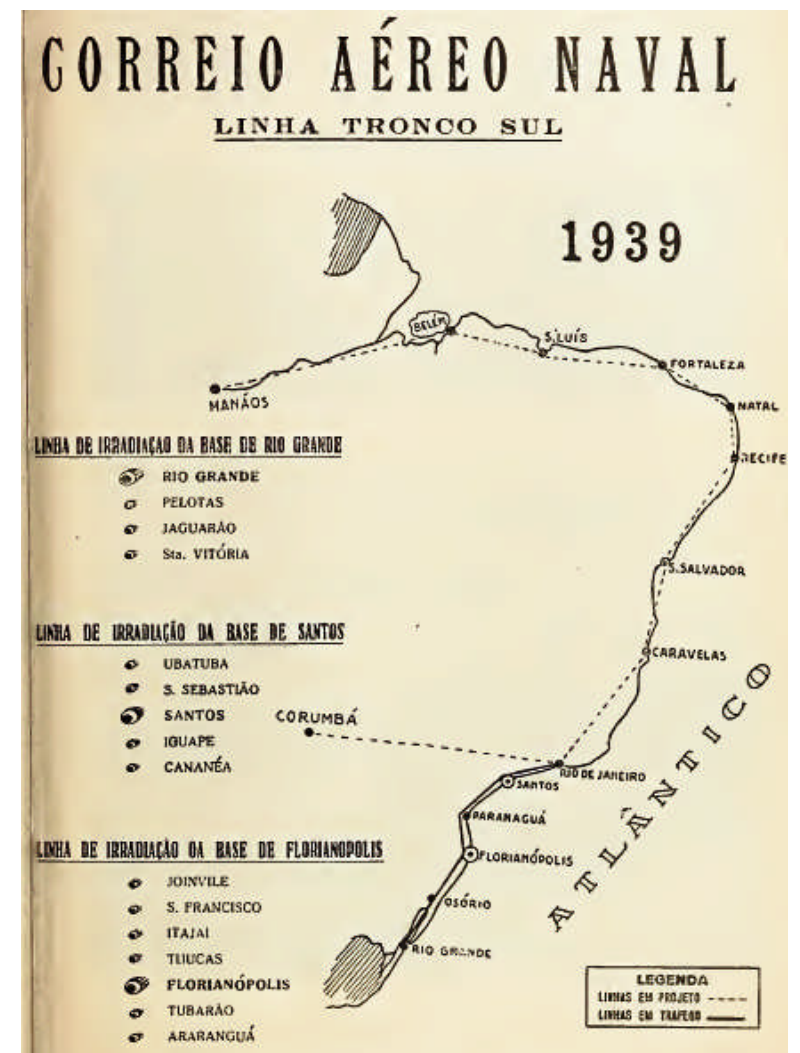

Figura 4 - Linhas do Correio Aéreo Naval, 1939. Fonte: Silva, 1949.

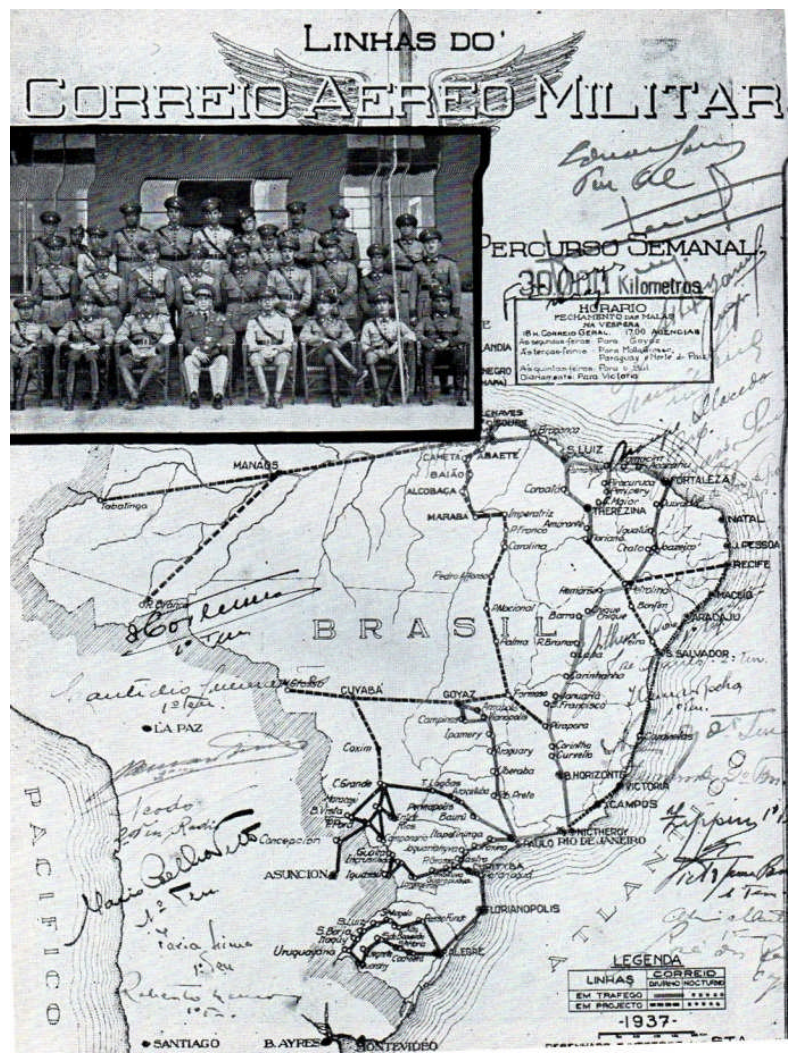

Figura 5 - Linhas do Correio Aéreo Militar, 1939. Fonte: Souza, 1946.

No mesmo ano de criação do DCT, foi fundado o Correio Aéreo Militar (CAM $)^{30}$, permitindo a remessa de correspondências a lugares quase inatingíveis do território nacional. Em 1941, em plena II Guerra Mundial (1939-1945), o CAM fundiu-se ao Correio Aéreo Naval fora formar o Correio Aéreo Nacional (CAN), em virtude da criação do Ministério da Aeronáutica (SOUZA, 1946). Essas ações foram compatíveis com um projeto de integração do território brasileiro, levado a cabo pelo Estado por meio de operações geopolíticomilitares. O mapa trazido por Moacir Silva na obra Geografia dos Transportes no Brasil apresenta as linhas do Correio Aéreo Naval em 1939, que acompanhavam as principais cidades do litoral brasileiro a sul do Rio de Janeiro, com projeção para o litoral do Nordeste e Norte até Manaus, e outra linha exclusiva que alcançaria Corumbá (Figura 4). Já a rede do CAM na mesma época era bem mais densa (Figura 5), partindo do Rio de Janeiro e São Paulo até as capitais dos estados e alcançando as regiões de fronteira: com o Uruguai, em Santana do Livramento; com a Argentina, em Uruguaiana, São Borja, Foz do Iguaçu e outras; com o Paraguai, em Guaíra, Ponta Porã, etc.; em Cáceres, fronteira com a Bolívia; em Tabatinga, na fronteira com o Peru e a Colômbia; e ainda previsão de chegar a Rio Branco. No caminho,

\footnotetext{
${ }^{30}$ O serviço iniciou em 12 de julho de 1931, com uma linha que ligava o Rio de Janeiro a São Paulo (SILVA, 1949).
} 
inúmeras cidades do interior eram conectadas por meio dos aviões do CAM, mas o objetivo maior era fomentar a consolidação e a presença do Estado na fronteira, por meio de um serviço rápido e seguro de comunicação postal.

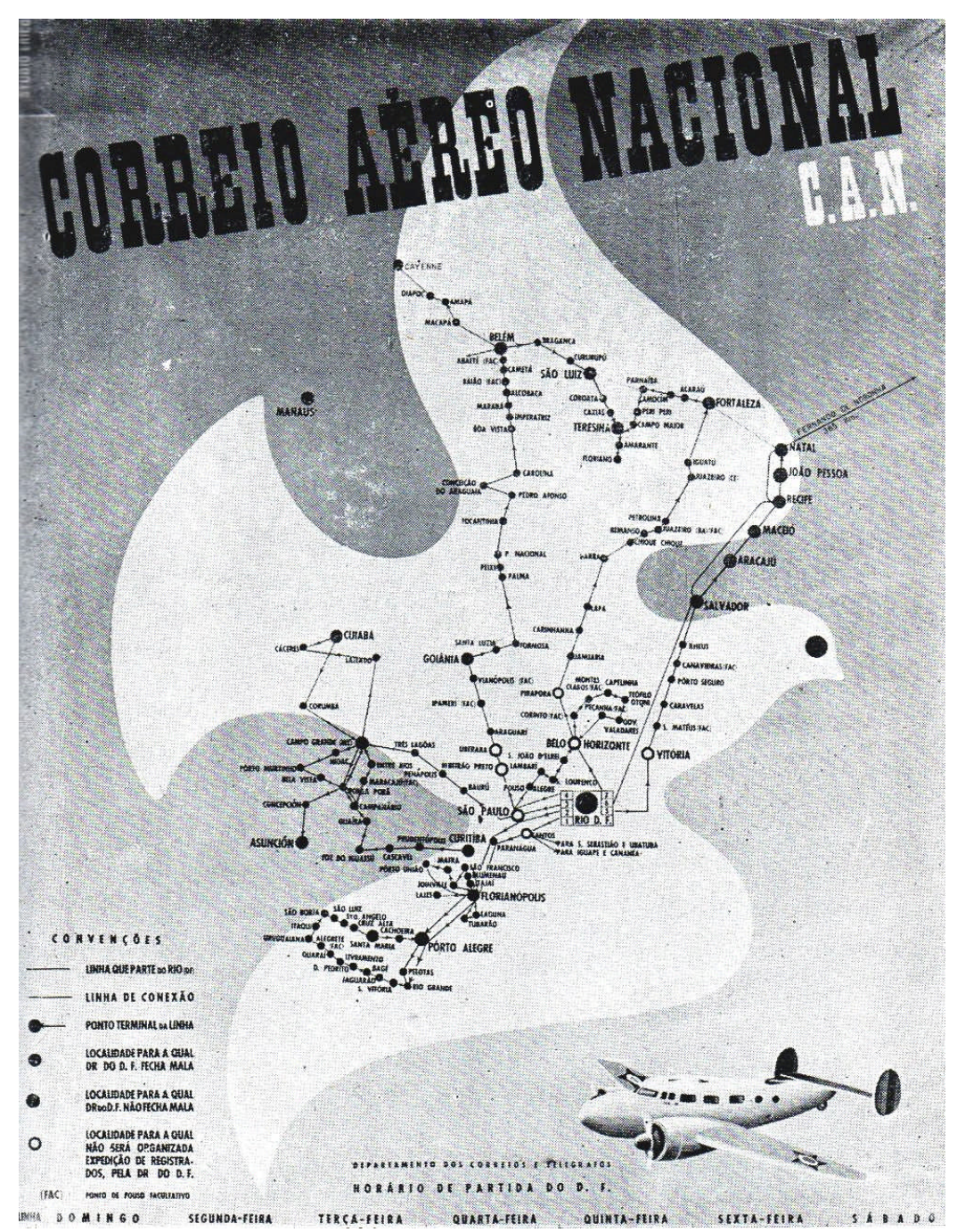

Figura 6 - Linhas do Correio Aéreo Nacional em 1945.

Fonte: Souza, 1946.

Herdeiro das linhas aéreas já constituídas anteriormente, o CAN organizou uma ampla rede aérea de transporte de correspondências a partir do Distrito Federal, à época localizado no Rio de Janeiro (Figura 6). Linhas partiam com destino a Natal, Fortaleza, Belém, Goiânia, Cuiabá, Porto Alegre, entre outras capitais, fazendo escala em muitas cidades que estavam na rota. Havia também linhas que começavam a extrapolar a fronteira nacional e chegar a países vizinhos, como a que alcançava Assunção, no Paraguai, e a linha projetada para chegar até La Paz, na Bolívia. As estratégias de utilização do modal aéreo chegaram a criar dois tipos de linhas para o litoral do Nordeste: uma mais rápida, saindo do Rio de Janeiro e parando em 
Salvador, Recife e Natal; e outra mais demorada que tinha o mesmo destino, embora realizando muitas paradas em cidades como Vitória, Porto Seguro, Ilhéus, Maceió e João Pessoa.

Comentando o mapa, Moacir Silva (1949, p.190) aponta que a periodicidade dos voos do CAN era semanal, fato que reduzia o tempo das entregas para alguns dias a partir da postagem; dizia ele: "o interior do Brasil é também cruzado, em quase todas as direções, pelo Correio Aéreo Nacional, que realiza vôos semanais de ida e volta em tôdas as suas rotas, prestando inestimáveis serviços de cooperação no transporte de correspondência postal aérea", além de realizar eventuais transportes de passageiros com autorização da Aeronáutica. A constituição da rede foi gradativa, revelando a política de integração territorial que estava por trás dessas ações: em 1931, a linha começou entre o Rio de Janeiro e São Paulo e daí se estendeu até Goiás; em 1934 foi inaugurada uma linha do Rio até Fortaleza, tocando em Belo Horizonte; entre 1934 e 1935 foi concluído um circuito no interior da Região Sul do Brasil, com nós em Porto Alegre e Curitiba; no ano seguinte, outra linha seguia para o Nordeste, desta vez pelo litoral; nos anos posteriores foi a vez de chegar a Belém, ao Mato Grosso, ao Paraguai e até mesmo à Bolívia.

\begin{tabular}{rrrrrrr} 
Ano & $\begin{array}{c}\text { Extensão das } \\
\text { linhas - mil } \\
\text { km (aprox.) }\end{array}$ & $\begin{array}{c}\text { Distância } \\
\text { percorrida - mil } \\
\text { km (aprox.) }\end{array}$ & Horas de voo & Passageiros & $\begin{array}{c}\text { Carga postal - } \\
\text { ton. (aprox..) }\end{array}$ & $\begin{array}{c}\text { Carga não- } \\
\text { postal - ton. } \\
\text { (aprox.) }\end{array}$ \\
\hline 1931 & 2 & 55 & 472 & 61 & $\mathbf{0 , 3 4}$ & \\
1932 & 4 & 127 & 865 & 17 & 0,13 & \\
1933 & 4 & 252 & 1.776 & 58 & 3,8 & \\
1934 & 8 & 616 & 4.279 & 121 & 10,4 & \\
1935 & 10 & 925 & 5.174 & 403 & 18,7 & \\
1936 & 12 & 1.081 & 4.449 & 577 & 24 & \\
1937 & 14 & 1.316 & 8.193 & 1.016 & 45 & \\
1938 & 15 & 1.663 & 10.003 & 1.072 & 48,2 & \\
1939 & 19 & 1.836 & 10.759 & 542 & 65,4 & \\
1940 & 19 & 1.542 & 8.625 & 759 & 42,5 & \\
1941 & 18 & 2.174 & 12.652 & 450 & 67 & \\
1942 & 23 & 2.417 & 14.758 & 428 & 132 & \\
1943 & 23 & 2.693 & 13.262 & 400 & 145 & \\
1944 & 34 & 2.567 & 13.173 & 544 & 209,7 & 47,1 \\
1945 & 31 & 3.432 & 18.475 & 253 & 186,9 & 51,7 \\
1946 & 49 & 3.723 & 14.922 & 14.154 & $\mathbf{1 . 4 4 5 , 3}$ & 499,8
\end{tabular}

Tabela 1 - Desenvolvimento do Correio Aéreo Nacional nos dezesseis primeiros anos (1931-1946). Fonte: Adaptado de Silva, 1949. 
É notória a importância da rede do CAN para o aumento do fluxo postal no Brasil (Tabela 1): o extraordinário incremento da extensão das linhas aéreas, de menos de 2 mil km para quase $50 \mathrm{mil} \mathrm{km} \mathrm{em} \mathrm{quinze} \mathrm{anos,} \mathrm{fomentou} \mathrm{o} \mathrm{crescimento} \mathrm{jamais} \mathrm{antevisto} \mathrm{do} \mathrm{volume}$ total de correspondências - de apenas 340 quilos, em 1931, chega a 66 toneladas dez anos depois, 200 toneladas em 1944 e, no de 1946, alcança o recorde impressionante de mais de 1.400 toneladas de carga postal.

No âmbito do mercado, expandem-se as relações de assalariamento por todo o país e, no correio, cria-se a Escola de Aperfeiçoamento dos Correios e Telégrafos, em 1934, iniciando um período de treinamento sistematizado da mão-de-obra em escala nacional. Também uma novidade introduzida pelo mercado foi o "aparecimento de inúmeras empresas concorrentes de correios e telégrafos, bem estruturadas, que se aproveitaram da ineficiência da DCT" (BOVO, 1997, p.23). Tratava-se de pequenas empresas, regionais ou locais, que ofereciam serviços similares de entrega de correspondências e pequenos pacotes. Comentando a conjuntura, Barros Neto (2004, p.43) revela que "ao iniciar os de 1930 os serviços públicos em geral, inclusive os postais, estavam em processo de acelerada degeneração", situação revertida a partir das medidas intervencionistas do denominado Estado Novo.

As novas máquinas de franquear disponíveis nas maiores agências de postagem, juntamente com o uso das ferrovias e aerovias para o transporte de malas, permitiram uma aceleração sem precedentes no tempo de circulação dos objetos. Graças aos avanços técnicos do período, os prazos de entrega foram encurtados de semanas para apenas alguns dias, rapidez que levou a uma série implicações espaciais. Quanto ao território, é possível falar numa conexão de sua área core $^{31}$ nesse período, mas não de todo o Brasil, contemplando o eixo em torno do Rio de Janeiro, São Paulo e Minas Gerais, e ligações pontuais a partir desse núcleo com as demais regiões. Pode-se admitir, com Furtado ([1959] 2007, p.328), que “o desenvolvimento da primeira metade do século XX apresenta-se basicamente como um processo de articulação das distintas regiões do país em um sistema mínimo de integração". A integração territorial nesse período apresenta uma manifestação desigual, tornando-se melhor compreendido se se considera que o desenvolvimento da segunda metade do século XIX não se estendeu a todo o país, acirrando a concentração geográfica da população, das infraestruturas e do poder político-econômico em torno da área dinâmica de cultivo do café, à época o principal produto brasileiro para exportação.

\footnotetext{
${ }^{31}$ Área central, nuclear.
} 


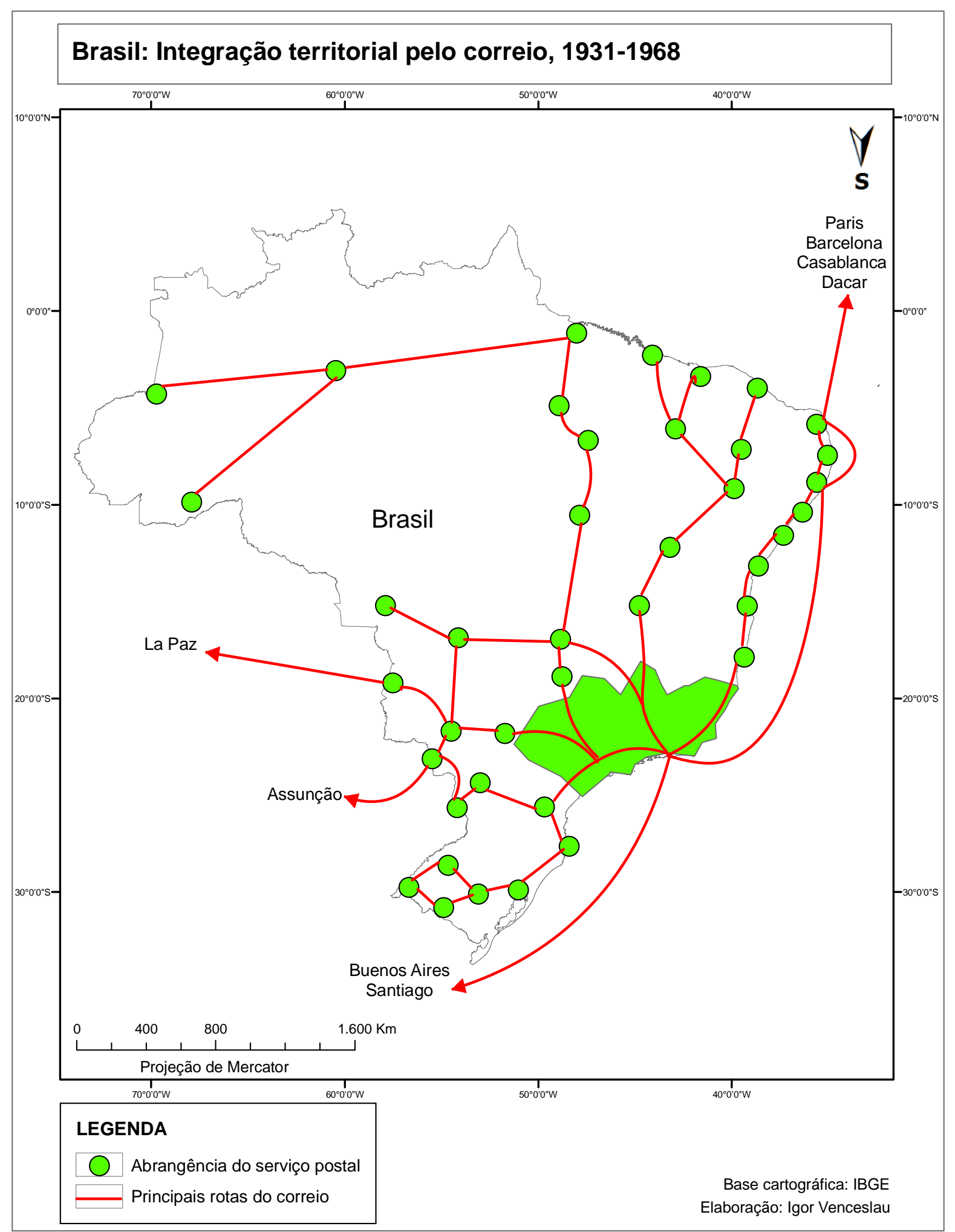

Mapa 3 - Brasil: integração territorial pelo correio, 1931-1968.

Fonte: Elaboração própria a partir de revisão bibliográfica e matriz de eventos. 
No terceiro período, o correio assumiu uma nítida função de integração das áreas mais afastadas ao núcleo econômico e político do país, sua área core, tornando-se parte de um projeto geopolítico de consolidação das fronteiras nacionais (Mapa 3). O aumento da espessura do meio técnico, por meio da introdução de novos objetos, permitiu maior rapidez às ações do correio, alcançando um estágio de integração territorial incompleta. Desse modo, a formação socioespacial brasileira internalizou elementos externos em favor de uma articulação interna, pois "o fator dinâmico principal, nos anos que se seguem à crise [de 1929], passa a ser, sem nenhuma dúvida, o mercado interno" (FURTADO, [1959] 2007, p.279). O uso do território para fins geopolítico-militares, nesse período, aponta para a centralização do poder em escala nacional e a produção de desigualdades regionais, com prevalência de fluxos numa área geográfica privilegiada.

Em 1968, o DCT passa a ser subordinado ao Ministério das Comunicações - criado pelo decreto lei n²00 de 1967, em pleno regime de ditadura militar, pela extinção do antigo Ministério da Viação e Obras Públicas e criação do Ministério dos Transportes (CORREIOS, 2016). Considerada por Poupard (1979, p.33) como a "mais importante e radical transformação dos serviços postais em todo o período", suas consequências seriam notadas sobre o correio nos anos seguintes.

\subsection{Quarto período (1969-1981): a Empresa Brasileira de Correios e Telégrafos e a consolidação da integração territorial}

A integração do território, que fora iniciada no segundo e ampliada no terceiro período, alcança um estágio de consolidação na escala nacional. Se, no período anterior, a integração foi um projeto estatal explícito, agora a tensão Estado - mercado se manifesta na forma como essa integração se consolida sob um modelo empresarial, ainda que se tratando de um serviço público. Nesse sentido, sob os auspícios de um governo de ditadura militar, a ação estatal mais contundente após a criação do Ministério das Comunicações foi a transformação do DCT em uma empresa ${ }^{32}$; nascia assim, em 1969, a Empresa Brasileira de Correios e Telégrafos ${ }^{33}$ - EBCT, ECT ou simplesmente Correios. O correio como empresa significou o corolário da transformação do objeto postal em mercadoria (GERTEL, 1991), iniciada, conforme apontado, com a adoção do selo (ver item 1.3). Com isso, o correio passa

\footnotetext{
${ }^{32}$ Inicialmente cogitou-se em a transformação do DCT em uma autarquia, mas a proposta vitoriosa foi o projeto apresentado pelo Ministério do Planejamento para a sua reformulação nos moldes de uma empresa (POUPARD, 1979).

${ }^{33}$ A Empresa Brasileira de Correios e Telégrafos foi criada pela Lei no 509 de 20 de março de 1969.
} 
a operar perseguindo ganhos de produtividade, redução de custos e aumento de receita (BOVO, 1997).

Além das normas criadas pelo próprio Ministério das Comunicações, a novidade no plano normativo foi a promulgação da Lei 6.538 de 22 de junho de 1978, que trouxe consequências importantes para o correio nas décadas seguintes, alcançando os dias atuais. A chamada Lei Postal, ainda em vigor, foi uma intervenção do Estado no conflito entre a prestação de um serviço público e a sua operacionalização nos moldes empresariais, manifestando a tensão entre a função social do correio e o objeto postal tornado mercadoria. Esse novo elemento regulatório teve três objetivos principais. O primeiro deles foi unificar as legislações postais existentes, que até então eram estaduais. Até esse momento, cada estado brasileiro possuía uma regulamentação diferenciada quanto ao peso máximo e mínimo dos objetos postados, seu tamanho, o valor das tarifas, entre outras especificações. Com a Lei Postal, foi possível realizar uma verdadeira unificação dos padrões e preços do correio na escala nacional. Em segundo lugar, como a integração territorial é também uma integração dos mercados nacionais, uma resposta do Estado ao avanço do mercado foi a regulamentação do monopólio postal, assegurando a prestação dos serviços de correio à União, em caráter exclusivo, que o realiza por meio da ECT. De acordo com o texto (BRASIL, 1978):

Art. $9^{\circ}$ - São exploradas pela União, em regime de monopólio, as seguintes atividades postais:

I - recebimento, transporte e entrega, no território nacional, e a expedição, para o exterior, de carta e cartão-postal;

II - recebimento, transporte e entrega, no território nacional, e a expedição, para o exterior, de correspondência agrupada;

III - fabricação, emissão de selos e de outras fórmulas de franqueamento postal.

Assim, ficaram excluídos da condição de monopólio os objetos do segmento de encomendas, o que recolocará o conflito alguns anos mais tarde. Por fim, a lei instituiu a universalização dos serviços postais no Brasil, ao declarar no artigo $4^{\circ}$ que "é reconhecido a todos o direito de haver a prestação do serviço postal e do serviço de telegrama, observadas as disposições legais e regulamentares", de alguma maneira incentivando o próprio Estado a oferecer os serviços básicos de correio em todos os municípios.

O aperfeiçoamento da mão-de-obra, iniciado sistematicamente no período anterior, alcançou outras regiões do país. Em 1971, um convênio celebrado entre os Correios e a Pontifícia Universidade Católica do Rio de Janeiro garantiu a formação de técnicos especializados de nível superior, os chamados administradores postais, bem como o oferecimento de cursos de treinamento para os funcionários de nível médio. No ano seguinte, 
foram inaugurados centros de treinamento na própria cidade do Rio de Janeiro, em Recife e Bauru-SP; e em Porto Alegre, em 1973. Nesse mesmo ano, o treinamento da empresa havia atingido a marca de quase dez mil ${ }^{34}$ funcionários contemplados com os cursos. Esse processo de implantação de centros de treinamento culminou na criação, em 1978, da Escola Superior de Administração Postal (ESAP), em Brasília, instituição de ensino nos moldes militares vinculada aos Correios $^{35}$.

Assim, pode-se afirmar, em concordância com Bovo (1997), que após a criação da ECT o correio brasileiro passou por uma reestruturação com vistas a intensificar a racionalização do trabalho. Isso foi possível por meio de um apoio de cooperação técnica com o correio francês que suscitou quatro missões especializadas no Brasil, entre 1971 e 1977, introduzindo conceitos e práticas do fordismo, taylorismo e fayolismo na rotina operacional e administrativa dos Correios. A influência francesa no correio brasileiro revela a superação de uma dependência histórica com o modelo inglês, embora aponte para a continuidade da influência de elementos externos ao país, ainda que agora objetivando um fomento à integração interna. Comentando os reflexos dessa reestruturação, o autor é incisivo:

É possível - como de fato ocorreu - racionalizar e reorganizar o trabalho do carteiro; sendo até possível motorizá-lo. Tudo isso repercute em ganho de tempo, mas, mesmo assim, o carteiro continuará a ser um profissional estratégico e necessário para a ECT. Esse aspecto constitui-se num limite à própria mecanização (BOVO, 1997, p.39).

Como apontado pelo autor, é nesse contexto que surge o trabalho motorizado do carteiro, ou seja, o uso de veículos (como carros e motos) para efetuar a entrega em domicílio, aumentando a produtividade do trabalho e acelerando a circulação postal.

Pela primeira vez, é possível falar numa integração nacional completa, sustentada por uma rede de fixos dos Correios e por fluxos que, com intensidades diferentes, se estendem a todo o país (Mapa 4); também pelo novo conteúdo normativo, que institui a universalização dos serviços e, assim, obriga a empresa a se instalar em todos os municípios brasileiros. Ainda em 1971, ações por parte da empresa levaram à expansão do número de agência e postos de atendimento e ainda houve a instalação de agências postais móveis e a ampliação do serviço de distribuição domiciliária (CORREIOS, 2016).

\footnotetext{
${ }^{34}$ Naquele ano, foram exatos 9755 funcionários capacitados com cursos de formação superior e outros, segundo os Correios (2016).

${ }^{35}$ Informações adquiridas em trabalho de campo realizado na Universidade Corporativa dos Correios, localizada em Brasília-DF, em março de 2016.
} 


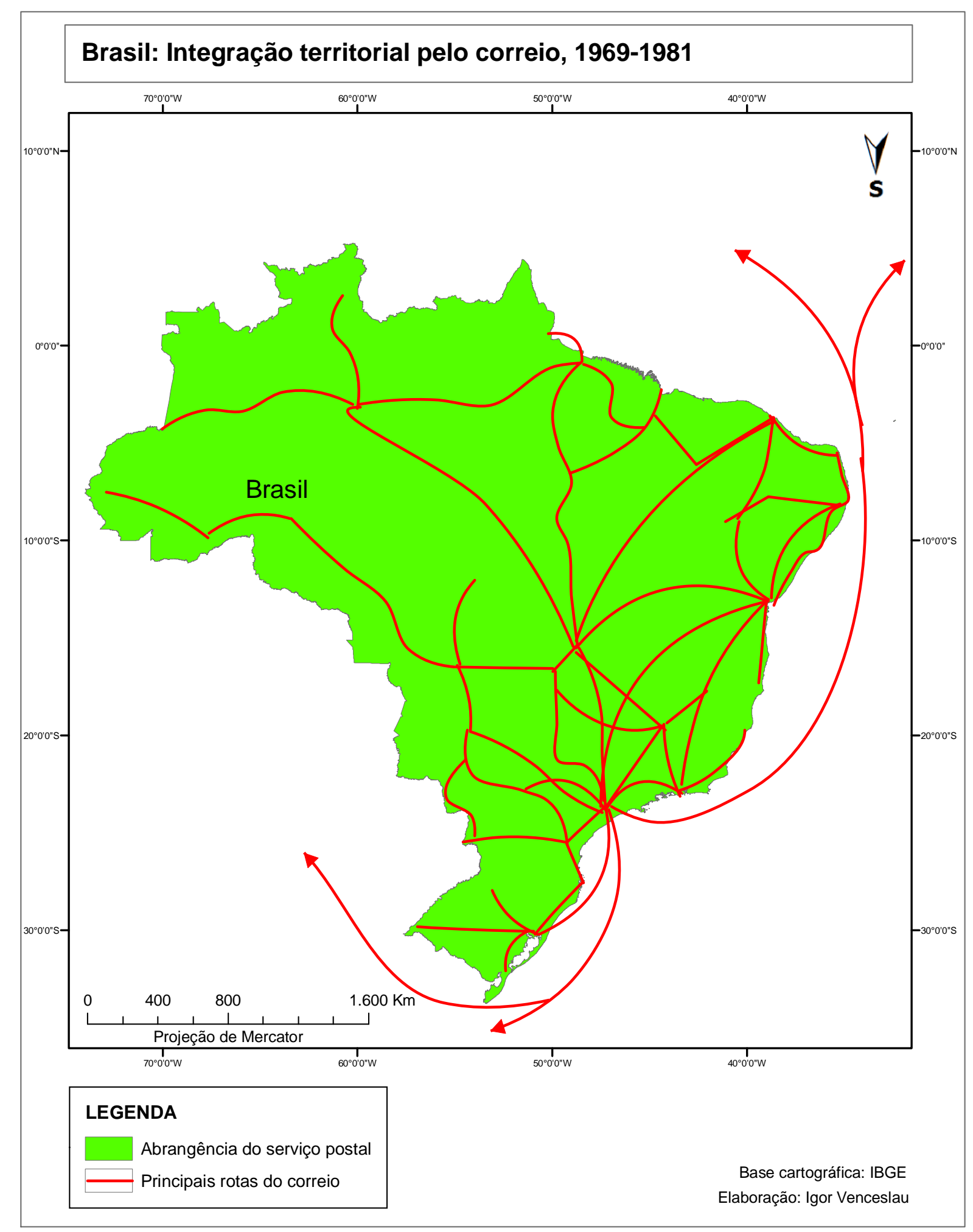

Mapa 4 - Brasil: integração territorial pelo correio, 1969-1981.

Fonte: Elaboração própria a partir de revisão bibliográfica e matriz de eventos. 
A capilaridade dos Correios alcança também os logradouros mais movimentos das capitais e cidades mais populosas por meio da criação de mais de cinco mil ${ }^{36}$ caixas de coleta $^{37}$, fixo postal contemporâneo à invenção do selo. Desta maneira, o Estado amplia a sua presença em todo o território nacional por meio dos Correios.

Nesse período, o modal de transporte ferroviário é completamente substituído pelo rodoviário. Uma das primeiras ações dos Correios foi transferir todo o transporte onde ainda se fazia sobre trilhos para o rodoviário fretado, com a racionalização das linhas de maneira articulada em diferentes escalas. Assim, em 1970 foram estabelecidas as chamadas Linhas Tronco (LT) dos Correios $^{38}$, que aceleraram o curso das correspondências e permitiram uma integração das capitais até as pequenas cidades, principalmente para os serviços de entrega não urgente.

Também o modal aéreo foi reformulado, com a substituição do CAN, do período anterior, pela nova Rede Postal Aérea Noturna (RPN), dos Correios. A partir do ano de 1974, todas as capitais dos estados passaram a ser articuladas diariamente pelos voos noturnos da RPN, com o objetivo de atender aos novos padrões de qualidade e velocidade estabelecidos para as cartas e encomendas urgentes.

Além do avião e do caminhão, a máquina de triagem foi um objeto técnico importante para acelerar a circulação no correio. O equipamento permitiu a automação dos procedimentos de separação de objetos por destino, portanto internos aos centros operacionais, conferindo uma aceleração inédita da circulação postal. O trabalho manual e lento de leitura e separação das cartas por destino foi substituído pela rapidez do novo objeto, indispensável para ações mais velozes nos centros de maior congestionamento da rede postal. Foi São Paulo a primeira cidade a contar com um centro de triagem mecanizado, construído em 1971, mesmo ano a entrar em operação um centro de triagem marítimo em Santos, destinado ao tratamento de encomendas internacionais; em seguida, a automação chegou ao Rio de Janeiro e a Brasília, em 1976 (CORREIOS, 2016), criando um arco em torno da região mais populosa e centro de gravidade econômica do país.

Mas a máquina de triagem só teve eficácia porque foi criado, antes de sua implementação, um sistema novo de racionalização do território, baseado na localização geográfica - o Código de Endereçamento Postal (CEP). O CEP, como passou a ser chamado, foi inspirado num modelo elaborado pelo correio francês para racionalizar a entrega nos

\footnotetext{
${ }^{36}$ Esse número corresponde a apenas uma grande intervenção ocorrida no ano de 1974.

${ }^{37}$ As novas caixas de coleta foram produzidas em fibra de vidro, tornando-se mais baratas e duradouras (CORREIOS, 2016).

${ }^{38} \mathrm{O}$ modelo das LT vigora até os dias atuais.
} 
arrondissements $^{39}$ de Paris e possui uma lógica de regionalização que vai dos logradouros e bairros da cidade até as regiões, estados e todo o país. No Brasil, o CEP foi implantado com uma lógica espiral ${ }^{40}$, acompanhando a forma do território, no sentido anti-horário a partir de cidade de São Paulo, numa ordem numeral crescente para o interior do estado de São Paulo, Rio de Janeiro e sucessivamente passando pelas regiões Norte, Nordeste, Centro-Oeste até os últimos números alcançarem o Rio Grande do Sul. No mesmo ano de implantação da máquina de triagem em São Paulo, foi lançado o primeiro guia postal brasileiro ${ }^{41}$ contendo todas as cidades e logradouros, padronizando o processamento de correspondências e encomendas em nível nacional ${ }^{42}$.

Aos poucos, o Rio de Janeiro ia perdendo importância como centro de decisões políticas e econômicas para o correio, expressando a dinâmica do próprio território. Com o significado simbólico que assumia a cidade de São Paulo por se tornar o centro de uma cartografia nacional do CEP, mas também por receber os primeiros equipamentos de automação e possuir maior capacidade de processamento, a capital paulista gradativamente ia se constituindo como o principal centro operacional dos Correios. Por sua vez, Brasília se firma definitivamente como centro de gestão da empresa com a inauguração, em 1978, do novo Edifício-Sede dos Correios $^{43}$ e a transferências de todas as funções administrativas para o planalto central, como parte das mudanças que vinham ocorrendo nos órgãos e empresas públicas desde a construção da nova capital.

O meio técnico se torna ainda mais artificializado com a introdução de novos objetos, autorizando maior velocidade e racionalidade às ações. O correio atinge, assim, um tempo muito rápido no processamento das correspondências, pois as condições técnicas e políticas apontadas permitiram uma aceleração de todo o processo que envolve as etapas de coleta (postagem), tratamento (triagem), transporte e entrega, de modo que os prazos puderam ser encurtados para um dia útil entre alguns pares de cidades.

A função desempenhada pelo correio, nesse período, foi de garantir uma integração territorial completa, assumindo atividades relacionadas à comunicação e ao transporte. A

\footnotetext{
39 Desde 1795, os arrondissements correspondem à divisão administrativa interna de Paris, somando hoje um número de vinte.

${ }^{40}$ Nos Estados Unidos e Canadá, por causa da forma do território daqueles países, seguiu-se uma lógica retangular, com numerações crescentes nos sentidos norte-sul e leste-oeste.

${ }^{41}$ À época, o CEP era constituído de apenas cinco dígitos. Posteriormente, conforme aumentava o número de logradouros e cidades, o código foi alterado para oito dígitos, modelo mantido até a atualidade.

${ }^{42}$ Informações adquiridas em trabalho de campo realizado na Vice-Presidência de Encomendas dos Correios, localizada em Brasília-DF, em março de 2016.

${ }^{43}$ Além da sede nacional dos Correios, aos poucos foram sendo inaugurados edifícios-sede nas diretorias regionais. Em São Paulo, sua criação data de 1981.
} 
formação socioespacial brasileira se volta para dentro, completando sua integração e intensificando as especificidades nacionais. Evidencia-se, portanto, usos do território que expressam a tensão entre Estado e mercado na condução do projeto de integração nacional.

\subsection{Quinto período (1982-dias atuais): os serviços expressos e a diferenciação do território}

O período anterior foi marcado por profundas reestruturações no correio brasileiro: da tensão entre Estado e mercado, foi criada uma empresa pública; no plano normativo, houve a unificação das legislações estaduais sob a Lei Postal, que instituiu um regime de monopólio estatal e a universalização dos serviços; a introdução da máquina de triagem, aliado ao uso do avião e do sistema de transporte rodoviário possibilitou a redução do tempo de entrega para um dia útil; dentro dos centros de tratamento, a rotina de trabalho sofreu um processo de racionalização; com as mudanças técnicas e normativas, assiste-se à consolidação da integração do território. Estavam lançadas as bases que permitiram aos Correios a criação, em 1982, do SEDEX, dando início ao período que se estende até os dias atuais.

$\mathrm{O} \mathrm{SEDEX}^{44}$ é um serviço diferenciado, criado para articular as principais capitais estaduais brasileiras entre si num prazo máximo de quatorze horas, utilizando como estruturador o modal de transporte aéreo (CORREIOS, 2016). Contempla tanto envelopes (tipo carta) quando pacotes (tipo encomenda), respeitando os limites máximos de peso ${ }^{45}$ e volume transportados pelos Correios. Esse novo objeto postal é intensivo em informação, pois seu oferecimento depende de uma variedade de insumos e outros objetos, articulados de forma sistêmica. A etiqueta com código de barras é indispensável para o serviço expresso dos Correios, pois permite encontrar rapidamente o objeto e acompanhar todo o processo produtivo. A etiqueta significa para o SEDEX aquilo que o selo postal representou para a carta tradicional no século XIX, assumindo uma função de comprovante de postagem, só que agora contando com outras informações no formato digital, como o peso, o preço e o destino do objeto.

O período contemporâneo se caracteriza pelo uso de tecnologias intensivas em informação. Surge, assim, o rastreamento dos objetos postais no espaço. Agora, há também a possibilidade de realizar a postagem eletrônica, serviço disponível para grandes clientes que

\footnotetext{
${ }^{44} \mathrm{O}$ termo "SEDEX" é alusivo à empresa estadunidense FedEx, uma das grandes corporações de correio privado (vide capítulo 2).

${ }^{45} \mathrm{O}$ peso máximo aceito pelos Correios para postagem regular em 2016 é de trinta quilos.
} 
podem imprimir a etiqueta desde seus próprios escritórios, reduzindo o tempo de espera do atendimento no balcão. A automação, que tinha contemplado os centros de operações na década de 1970, alcança agora as agências de atendimento, por meio do denominado Sistema de Automação da Rede de Atendimento (SARA), permitindo o fluxo integrado de informações e o rastreamento dos objetos em todas as etapas, da postagem à entrega. Mais recentemente, o trabalho do carteiro foi modificado com início do uso de aparelhos do tipo smartphone, fazendo que as informações referentes à distribuição domiciliária sejam transmitidas instantaneamente.

Quanto aos transportes, intensificou-se o uso dos modais já consolidados no período anterior, principalmente o aéreo - para a carga expressa - e o modal rodoviário. A novidade é a criação da Rede Postal Fluvial da Amazônia, conectando as cidades ribeirinhas da Região Norte do país ao modelo de intermodalidade já empregado por outras redes, como a RPN e as LTNs. Essa rede de transporte fluvial pode ser compreendida, por um lado, como uma expressão da diversidade regional brasileira e da coexistência de diversos meios geográficos, e por outro da combinação, conflitiva e complementar, entre o velho e novo no território.

Conforme se intensificam os fluxos ${ }^{46}$, aumenta o número de fixos postais especializados, gerando ainda mais fluxos - materiais e imateriais (informacionais). Em 1996 foi inaugurado o novo terminal de carga postal do Aeroporto do Galeão, no Rio de Janeiro; em seguida, é construída a segunda maior base da Rede Postal Aérea Noturna, no ano 1999, em Brasília; no mesmo ano foram inaugurados o Centro Operacional de Fortaleza e o Centro de Operações Benfica, este no Rio de Janeiro; a partir do ano de 2000, mais de cem cidades do interior paulista passaram a receber malas postais pelo novo Centro de Operações de Bauru, com capacidade para $520 \mathrm{mil}$ objetos/dia; amplia-se a capacidade do Centro de Tratamento do Jaguaré, em São Paulo-SP, a maior unidade operacional dos Correios, por meio da implantação de máquinas de triagem de esteira dupla; a cidade de Salvador-BA recebe um novo terminal de operação aérea em 2005 (CORREIOS, 2016).

Graças à instantaneidade da informação e a coordenação sistemática das ações por ela possibilitada, os prazos de entrega foram dramaticamente reduzidos, passando agora a ser contados em horas. Essa é a noção de tempo expresso, internalizada pelos Correios. No caso do telegrama, desde 2003 o serviço passou a contar com um prazo máximo de entrega de duas horas, o que exige monitoramento constante e prontidão do corpo de trabalhadores e dos

\footnotetext{
${ }^{46}$ No Brasil, o número de correspondências e encomendas dos Correios aumentou de 1,5 bilhão em 1980 para 3,6 bilhões em 1989 (BOVO, 1997). Hoje esse número está próximo dos 10 bilhões de objetos/ano (CORREIOS, 2016).
} 
veículos para realizar a entrega, além da operação online de todos os sistemas da empresa. Contudo, não basta ser veloz; as técnicas atuais possibilitam a precisão das ações, permitindo aos Correios oferecer serviços postais e telegráficos agendados de entrega com data e hora marcada. Essas ações revelam a interferência dos modelos just in time, também denominados flexíveis, sobre a rotina operacional e a carteira de serviços oferecidos aos clientes da empresa.

A influência das ações do mercado sobre o correio pode ser notada na diversificação dos serviços, principalmente aqueles do segmento expresso. As possibilidades de articulação via postal se ampliam, contanto com serviços que possuem horários determinados de entrega: no ano de 2001 foi lançado o SEDEX 10, modalidade que garante a entrega até às dez horas do dia útil seguinte à postagem; em 2004 foi a vez do SEDEX Hoje, com entrega garantida no mesmo dia da postagem, e o SEDEX Mundi, serviço expresso internacional; por fim, o SEDEX 12, lançado em 2013, foi uma alternativa de entrega até $12 \mathrm{~h}$ do dia seguinte à postagem para aquelas localidades onde o prazo do SEDEX 10 não conseguia ser cumprido (CORREIOS, 2016).

Neste período, o Estado estende sua presença a todo o território nacional, por meio da rede postal. Além de possuir agências em todos os municípios, os Correios começaram a entrega na zona rural de algumas regiões do país a partir de 1985. As vilas e povoados com população de até quinhentos habitantes ou de difícil acesso passaram a contar, desde 1998, com a implantação de caixas postais comunitárias, permitindo aos moradores a utilização de um endereço único e retirada das correspondências na agência comunitária, garantindo o acesso a um serviço postal mínimo. Explicando esse processo, Gertel (1991, p.119) comenta que

A estrutura de operacionalização criada possibilitou uma posição privilegiada ao fluxo de correspondência de maneira a atingir o amplo espectro da sociedade e qualquer ponto do território nacional, desde o cidadão localizado na zona rural até a grande empresa que gostaria de a esse atingir, ou vice-versa. As possibilidades são múltiplas e concretas porque não foi só pelo aspecto das infraestruturas tradicionais, como a dos transportes, da coleta e entrega, dos carteiros, etc., que o aperfeiçoamento ocorreu.

Uma vez constituída uma rede postal em escala nacional, não somente o Estado se tornou mais presente, como também o mercado pode tirar proveito dessa "infraestrutura". O conflito entre Estado e mercado manifesta-se nas políticas neoliberais que marcaram a década de 1990 no Brasil. Várias empresas públicas foram privatizadas, além da abertura de mercado para a exploração de serviços públicos, inclusive aqueles relacionados às comunicações. 
Apesar da existência de projetos e articulações políticas para realizar a venda desse patrimônio, os Correios permaneceram como uma empresa pública.

No âmbito normativo, foi mantido o monopólio postal instituído no período anterior. A nova constituição federal promulgada em 1988 ratificou tanto o privilégio da União em realizar sua prestação como também a universalização do serviço postal, uma vez que o texto declara, em seu Artigo 21, ser de competência da União "manter o serviço postal e o correio aéreo nacional" (BRASIL, 1988). Contudo, desde a carta magna dois projetos diferentes disputam os rumos do correio no país. Durante a década de 1990, uma proposta denominada "nova Lei Postal" visava abrir o mercado postal para a iniciativa privada, da mesma forma que ocorreu com as telecomunicações, mas foi abortado na década de 2000 quando o país ratificou a política em prol dos Correios. Estudando o correio brasileiro nos anos recentes, Teixeira (2013, p.257) concluiu que

Do ponto de vista das estratégias políticas para o setor postal, portanto, há uma diferença entre os blocos políticos que ocuparam o governo federal no período. Observa-se que o projeto do governo FHC [Fernando Henrique Cardoso] visava modernizar a ECT provendo a competição no setor postal a partir da liberalização de mercado. Assim, as ações políticas desse governo estavam alinhadas ao projeto neoliberal. Durante o governo Lula e os primeiros anos do governo Dilma Rousseff, as propostas e as mudanças na corporatização dos Correios visam ampliar a atuação de mercado e a inserção internacional da estatal. Assim, enquanto naquele governo havia a previsão de redução do papel do Estado e, por conseguinte, dos Correios, a partir de 2002 se observa o governo do PT atuando em prol do fortalecimento institucional e mercadológico da empresa, prevendo inclusive a sua internacionalização. São duas perspectivas de mercado, portanto, distintas.

O surgimento do regime de franquias nos Correios é outra atribuição do mercado. Iniciado em 1989, trata-se de uma parceria que objetiva ampliar a prestação de serviços na forma de agências de atendimento ao público para postagem, oferecendo os serviços básicos dos Correios. Mais recentemente, foi promulgada a Lei 11.668 de 2008, dispondo e regulando sobre as franquias postais. Ressalte-se que as franquias não substituíram a rede de agências próprias dos Correios, sendo uma forma complementar de expansão do atendimento, principalmente nas maiores cidades. Todos os municípios do país continuaram contando com, no mínimo, uma agência própria (não franqueada) dos Correios.

Elemento externo, as empresas multinacionais de correio empreenderam um conjunto de ações para adentrar ao mercado nacional. Conjuntamente, as empresas FedEx, UPS e DHL entraram com pedido para a quebra do monopólio postal da União, junto ao Supremo Tribunal Federal, em 2009, cuja decisão do órgão judiciário foi favorável à manutenção do regime de 
exclusividade dos Correios. Nesse caso, nota-se o conflito entre agentes internos e externos pela regulação - Antas Jr. (2005) fala de uma "regulação híbrida do território", que inclui agentes como o Estado, as empresas, as ONGs, etc. - e pelo uso do território brasileiro, cuja especificidade da formação socioespacial faz do mercado nacional um dos mais atrativos para o setor postal privado.

As diferentes etapas da atividade de correio - coleta (postagem), tratamento (triagem), transporte e entrega - passaram a ser coordenadas a partir de uma mesma lógica de circulação, aumentando a racionalidade e velocidade dos fluxos: a logística. A introdução de conceitos e práticas da moderna logística empresarial na rotina dos serviços postais é uma característica marcante do período vigente, pois não é mais possível compreender o correio segundo as suas diferentes etapas de maneira segmentada.

A ciência assume um papel central na coordenação das ações no período atual, cuja manifestação mais acabada foi a fundação da Universidade Corporativa dos Correios UniCo, em 2000, com campus em Brasília, em substituição à Escola Superior de Administração Postal, herdada do período anterior. A UniCo é a repartição responsável por todas as ações de treinamento, produção, coleta e transmissão de conhecimento dentro da empresa, oferecendo desde cursos de graduação e pós-graduação até modalidades de capacitação à distância, realizadas por computadores na própria unidade de trabalho do empregado dos Correios.

A criação dos serviços expressos deve ser compreendida, portanto, como uma resposta do correio ao meio técnico-científico-informacional. Agora que as técnicas autorizam uma instantaneidade da informação, os fluxos materiais atingem uma velocidade inédita na história postal brasileira, modernização que permite uma atualização constante dos serviços postais e a (re)criação de novas formas e normas no território.

Uma vez integrado, o território brasileiro passa a ser diferenciado desde a criação de serviços postais expressos, que promovem temporalidades e modalidades diferentes de articulação em rede de alguns pontos (Mapa 5). Por isso mesmo, Santos ([1996] 2012, p.267) já havia constatado que "o tempo rápido não cobre a totalidade do território nem abrange a sociedade inteira". Assim, a seletividade espacial passa a ser um atributo do território integrado, diferenciando-o internamente. 


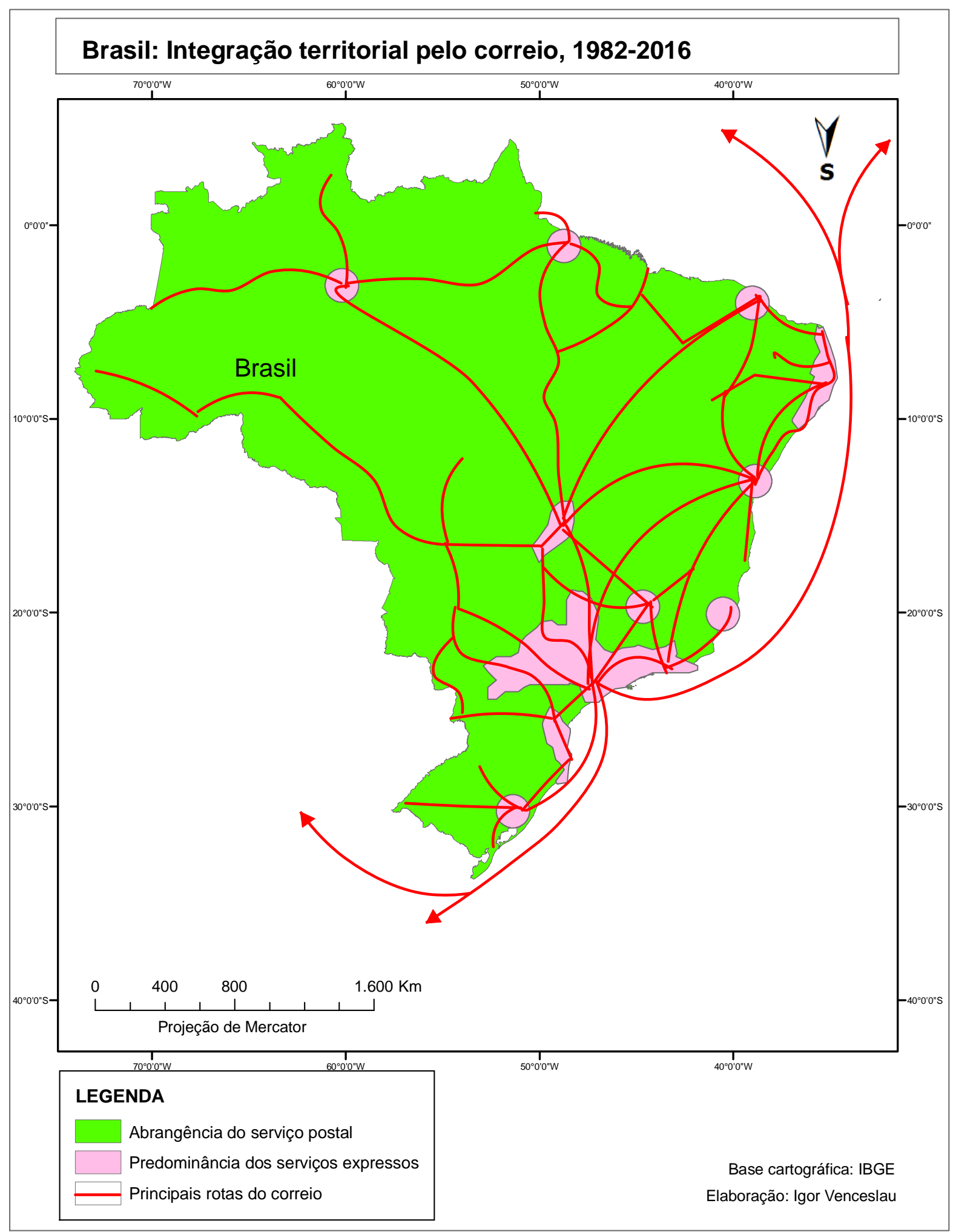

Mapa 5 - Brasil: integração territorial pelo correio, 1982-2016.

Fonte: Elaboração própria a partir de revisão bibliográfica, matriz de eventos e dados da cobertura do SEDEX. 
A formação socioespacial brasileira alcança um maior grau de complexificação, ao mesmo tempo assegurando sua unidade interna, mas sem superar completamente as desigualdades regionais historicamente produzidas. Assumindo funções diversas que vão desde a tradicional comunicação, passando pelo transporte e a logística, chegando até a operação de grandes projetos estatais e o e-commerce, o correio do século XXI fomenta diferentes usos do território, tanto para agentes hegemônicos como para aqueles cujas ações estão amparadas em outras lógicas.

Ao analisar a história postal do Brasil, conclui-se que o correio foi - e ainda é - um elemento importante na formação socioespacial brasileira, tendo participado ativamente do processo de integração do território nacional. Uma leitura atenta dos períodos aqui apresentados é reveladora, inclusive, das diferentes e complementares etapas da integração territorial correspondentes a cada um deles (Figura 7).

Se no início desse processo o correio funcionava apenas para assegurar ligações com o exterior, ao longo dos séculos as suas ações foram gradativamente garantindo conexões internas, acompanhando as sucessivas mudanças no conteúdo técnico e político do território. Ao analisar o Brasil ao longo dos anos, percebe-se que à complexidade do meio, que de natural se transforma em meio técnico e posteriormente se metamorfoseia em meio técnicocientífico-informacional, corresponde o aumento da complexidade do correio em sua expressão geográfica. Observando as etapas de integração territorial pelo correio, chega-se à própria história do território brasileiro, podendo ser evidenciados alguns processos geográficos, tais como: a dinâmica de localização do centro de gravidade econômica do país, que da porção nordeste passa ao Rio de Janeiro e posteriormente a São Paulo; na escala internacional, os principais países com os quais se estabeleceram relações comerciais e políticas, primeiramente Portugal, seguido da Inglaterra e, mais recentemente, outros países da Europa, países vizinhos e os Estados Unidos; a interiorização do povoamento e das atividades produtivas, com a consequente consolidação das fronteiras nacionais. 
BRASIL: INTEGRAÇÃO TERRITORIAL PELO CORREIO, 1663-2016
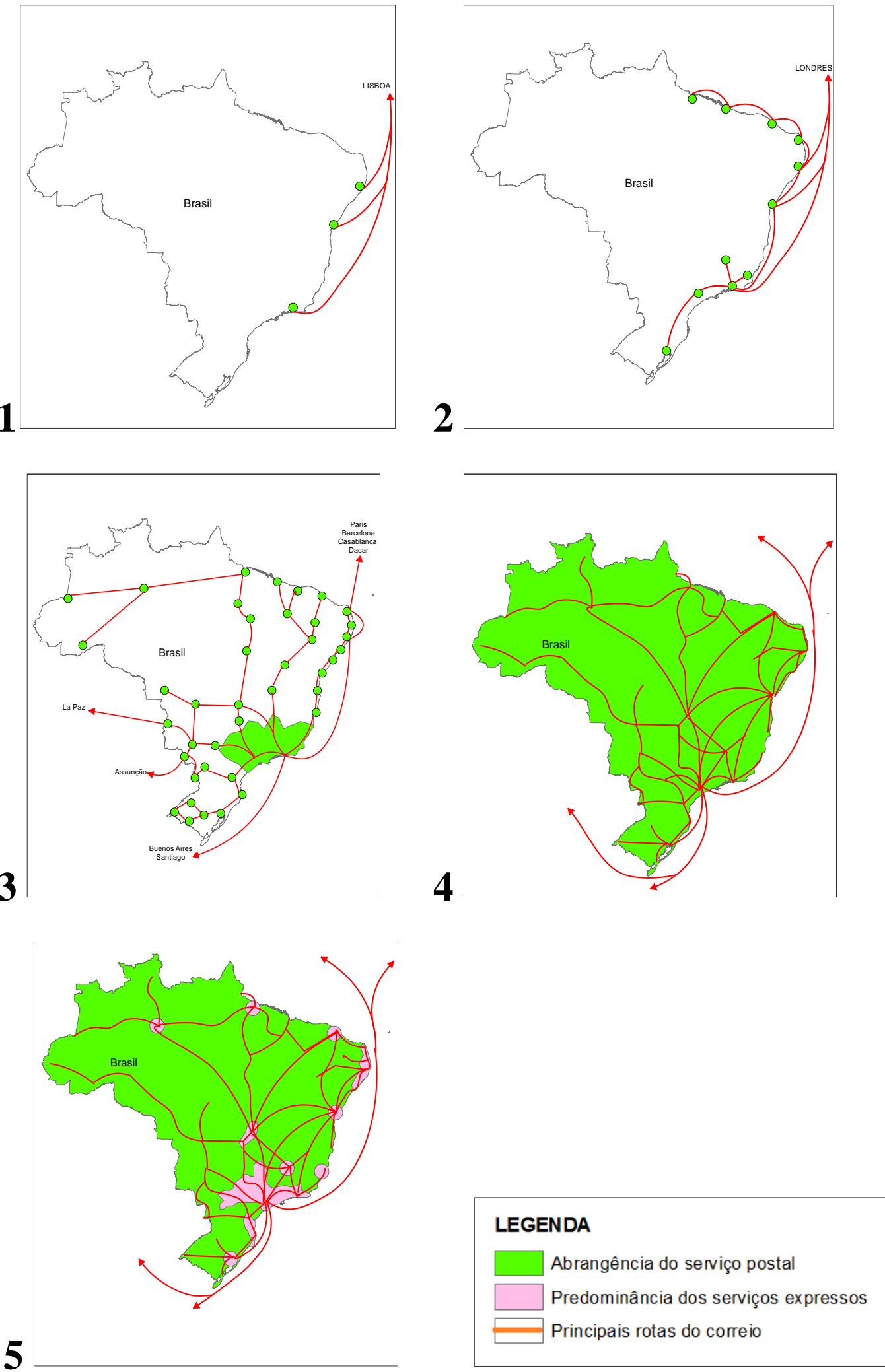

Elaboração: Igor Venceslau

Figura 7 - Etapas da integração do território brasileiro pelo correio entre 1663 e 2016.

Fonte: Elaboração própria a partir de revisão bibliográfica, matriz de eventos e dados da cobertura do SEDEX. 
Como um serviço predominantemente urbano, o correio e a sua difusão no território brasileiro acompanhou o processo de urbanização do espaço. De núcleos relativamente desconexos no litoral, passando pela interiorização e a constituição de uma região mais densa no sudeste, a urbanização alcança todas as regiões do país, em maior ou menor grau. Os serviços expressos vêm ao reforço da urbanização, correspondendo ao contemporâneo processo de metropolização do espaço, seletivo e pontual.

Nos dias atuais, as áreas onde predominam dos serviços expressos são, em grande parte, correlatas àquelas onde os serviços postais tradicionais foram inicialmente ofertados. Também, a seletividade dos serviços mais rápidos reproduz hoje aquela rarefação no oferecimento dos serviços mais básicos do passado. Essa conclusão é reveladora do papel da formação socioespacial e das formas pretéritas do território para os novos usos engendrados pelos agentes do presente, autorizando-nos a reconhecer, com Santos ([1993] 2006), o papel ativo do território.

Os capítulos seguintes abordarão esses e outros elementos do correio na contemporaneidade. Para melhor compreender a especificidade do Brasil, faz-se necessário, em primeiro lugar, traçar um panorama do correio no mundo com as transformações mais significativas das últimas décadas, revelando as formas de cooperação e conflito entre os diferentes agentes e a importância do território e da fronteira nacional para os fluxos postais. 
Com as asas nos pés, voas pelo espaço, cantando toda a música, em todas as línguas

Excerto de hino órfico a Hermes

Muitas das mudanças que o correio brasileiro experimentou no último quartel do século XX são produto de um conjunto de transformações estruturais e de ações engendradas desde fora com fortes implicações no território nacional. Entretanto, nem todos os eventos externos repercutiram internamente da mesma maneira, dada a mediação exercida pela formação socioespacial, marcando a especificidade do correio no país. A compreensão das transformações do correio numa escala mundial permite-nos reconhecer a origem - histórica e geográfica - de alguns conflitos que envolvem o serviço postal na atualidade, como as discussões em torno do monopólio postal, da manutenção da empresa pública, da universalidade dos serviços, de sua relevância atual, entre outros. Com isso, também será possível assinalar as tendências gerais do correio, subsidiando um debate político acerca das possibilidades e limites das escolhas do Brasil com respeito ao setor postal.

Quais são as principais transformações sofridas pelo correio na globalização contemporânea? Que características assumem os serviços postais na atualidade, considerando a diversidade de países em seu conteúdo técnico e político, os agentes envolvidos e os conflitos relacionados? Que relevância têm, hoje, território e fronteira nacionais para os fluxos postais? Essas questões nortearão as análises que se seguem, cujo objetivo é apresentar um quadro panorâmico do correio em escala mundial na atualidade, permitindo compreender a especificidade do Brasil no mundo, bem como a multiplicidade de agentes e a complexidade dos conflitos relacionados ${ }^{47}$. Essa atualidade diz respeito à fase contemporânea marcada pela globalização e pelo acirramento da divisão internacional do trabalho.

Por divisão internacional do trabalho (DIT) entende-se a especialização produtiva e o consequente intercâmbio entre países, tomados como unidades econômicas cujo desenvolvimento histórico é particular (SINGER, 1976). O conceito de DIT é derivado de

\footnotetext{
${ }^{47}$ Os resultados apresentados neste capítulo foram em grande parte desenvolvidos durante o estágio de pesquisa realizado na University of Kentucky, EUA, sob supervisão da Profa. Dra. Susan Roberts. Como mencionado em nota anterior, o estágio só foi possível graças ao apoio financeiro concedido pela FAPESP durante os seis meses de suas realização.
} 
outro conceito caro à tradição marxista, a divisão social do trabalho, sendo que este se refere a empresas ou ainda a indivíduos. O conceito de DIT é de particular interesse para as análises subsequentes, pois permite uma empiricização geográfica dos diferentes papeis desempenhados pelos países, com consequências sobre a forma como estes se inserem numa economia globalizada e as causas das trocas desiguais.

A globalização aprofunda e intensifica a divisão internacional do trabalho. Estamos considerando a globalização como o "ápice do processo de internacionalização do mundo capitalista" (SANTOS, [2000] 2011, p.23), cujas origens remontam ao expansionismo europeu do século XVI, que se intensificou sobremaneira com o imperialismo no final do século XIX e consolidou-se definitivamente na segunda metade do século XX. Na fase atual da globalização, é possível notar que os tradicionais meios de transporte, de comunicação e de informação "agilizam-se universalmente" (IANNI, [1995] 2010a, p.212), uma aceleração sem precedentes na história. Essa aceleração proporcionada pelas novas tecnologias contribuiu de maneira significativa para consolidar a globalização tanto como uma realidade empírica e parte do imaginário popular quanto como um conceito, portanto mais que um simples termo largamente empregado (DICKEN, [1986] 2011) ${ }^{48}$.

Foi a partir da década de 1970, sobretudo, que o correio experimentou mudanças inexoráveis em escala mundial, a começar pelos Estados Unidos e países da Europa Ocidental, impulsionadas pela conjuntura de transformações pelas quais o mundo (capitalista, principalmente) vinha passando. Todas essas transformações se apresentaram aos países de uma maneira generalizada, mas sua realização depende da mediação das formações socioespaciais, com particularidades na forma como os eventos se combinam e incidem sobre os lugares. Assim, ressaltamos que o conteúdo que será aqui apresentado refere-se a tendências gerais que têm se realizado com maior ou menor intensidade a depender das condições - técnicas e políticas - internas dos países, entre os quais optamos por destacar os casos do Brasil, pelos objetivos gerais do trabalho, e dos Estados Unidos, por questões históricas e geográficas que lhes atribuem algum destaque.

\footnotetext{
48 "Globalization is a concept (though not a term) whose roots go back at least to the nineteenth century, notably in the ideas of Karl Marx. But it has only been in the last 30 years or so that globalization has entered the popular imagination in a really big way. Now it seems to be everywhere" (DICKEN, [1986] 2011, p.2).
} 


\subsection{Do correio tradicional ao correio moderno}

Após o término da Segunda Guerra Mundial (1939-1945) e as várias décadas de conflitos que marcaram a primeira metade do século XX, inicia-se uma fase de cooperação internacional assinalada, por um lado, pela criação da Organização das Nações Unidas (ONU), em 1945; e, por outro lado, pelo alinhamento geopolítico dos países em torno de dois blocos distintos. A divisão entre os blocos socialista e capitalista se arrastou pelas décadas seguintes, durante a chamada Guerra Fria, até culminar na queda do Muro de Berlin e a unificação da Alemanha Ocidental e Oriental, em 1989, e o esfacelamento da União Soviética, em 1991. Quanto à ONU, teve rápida adesão de países de ambos os blocos e chegou ao século XXI contando praticamente com a totalidade dos países do globo dentre seus membros, tornando-se indispensável a qualquer análise da globalização contemporânea.

A ONU atua por meio de suas mais de vinte agências especializadas, dentre as quais figura a União Postal Universal (UPU). A incorporação da UPU ao sistema intergovernamental das Nações Unidas ocorreu em 1948, mas sua fundação remonta ao terceiro quartel do século XIX (conforme apontado no item 1.3), sendo considerada a segunda organização internacional mais antiga do mundo ${ }^{49}$. Desde o Tratado de Berna em $1874^{50}$, a união atua no incentivo ao desenvolvimento dos serviços postais em todos os paísesmembros, prestando inclusive assessorias técnicas. Suas ações também incluem uma função normativa, permitindo a regulamentação da circulação de cartas, encomendas e remessas postais de dinheiro no âmbito internacional, por meio de acordos que buscam harmonizar as tarifas e uniformizar os procedimentos e técnicas empregadas pelos correios. Atuando ainda como árbitro, o órgão investiga e combate casos de violação do sigilo das correspondências e de censura postal pelos países e autoridades competentes (MATTELART, 1994).

Mantendo sua sede na capital suíça, a UPU está atualmente constituída por 192 países membros ${ }^{51}$, cobrindo virtualmente todo o planeta. Suas ações contemplam parcerias com outras organizações para o cumprimento de finalidades comuns, dentre as quais merecem destaque: a Organização Mundial do Comércio (OMC), para a liberalização do mercado postal; a Organização Mundial da Saúde (OMS), para o transporte de substâncias biológicas

\footnotetext{
${ }^{49}$ A primeira foi a União Internacional de Telecomunicações - UIT, fundada em 1957 (MONTGOMERY, 2002). Com sede em Genebra, Suíça, a UIT também foi incorporada à ONU como uma agência especializada.

${ }^{50}$ Assinado no dia 9 de outubro, data em que é comemorado o Dia Mundial do Correio.

${ }^{51}$ Qualquer país membro da ONU pode automaticamente engajar-se na UPU. Do contrário, dois terços dos membros da união devem aprovar a entrada de um país que não esteja filiado às Nações Unidas.
} 
perigosas e perecíveis ${ }^{52}$; a Organização das Nações Unidas para a Educação, Ciência e Cultura (UNESCO), para a distribuição de material educativo; a União Internacional de Telecomunicações (UIT), para a normalização do correio eletrônico e transferência de fundos; a Associação Internacional de Transporte Aéreo (IATA), para o funcionamento do correio aéreo; e a Agência Internacional de Energia Atômica (AIEA), com vistas à detecção de substâncias radioativas em correspondências (MONTGOMERY, 2002).

Para Roberts (1995), essas são as “organizações transestatais de cima” (trans-state organizations "from above"), que possuem a atribuição de regular numa escala que extrapola as competências de cada um dos Estados nacionais isoladamente. Diferente das "organizações transestatais de baixo" (trans-state organizations "from below"), que para a autora correspondem àquelas que atuam em diversos países, mas sem estarem atreladas formalmente aos Estados, como no caso das organizações não-governamentais (ONGs).

Assim, revela-se uma "divisão do trabalho na regulação" (ARROYO, 2000), com participação ativa dessas organizações governamentais que operam como regimes de regulação internacional do correio. Para a autora, essas organizações "são controladas desde sua origem pelos países centrais" e acrescenta que "sua ação principal consiste em incluir no seu campo de competências tudo quanto se relaciona com as mudanças estruturais na ordem internacional" (ARROYO, 2009, p.491). Analisemos essas mudanças estruturais no âmbito do correio.

A entrada da UPU na ONU pode ser compreendida como um marco inicial emblemático para a transformação gradual de uma rede postal mormente constituída por fluxos nacionais em outra, estruturadora de uma circulação postal na escala do mundo. A criação da UPU já tinha instituído o que a literatura denomina território postal único, que foi intensificado com a sua adesão às Nações Unidas. Esse princípio da unicidade do território consta no primeiro artigo da Convenção de Berna, correspondendo a uma permuta recíproca de postagens dos correios dos países assinados com benefícios de todas as partes. Para Poupard (1979, p.9), a partir dessa concepção de território postal único foi possível uma "equivalência das taxas em todos os países membros", mas também a "obrigatoriedade de tratamento das correspondências postais indistintamente", sejam elas do próprio país ou de qualquer outra parte do mundo.

\footnotetext{
52 A cooperação entre a UPU e a OMS ficou mundialmente conhecida no caso do combate ao terrorismo biológico praticado pelo envio de cartas com a bactéria antraz (Bacillus anthracis) em 2001, que afetou principalmente regiões dos Estados Unidos e do sudeste asiático.
} 
Apesar de sua nomenclatura, o território postal único deve ser entendido como um "símbolo", aqui utilizando as palavras de Poupard (1979, p.9). Isto porque sua constituição está muito longe de ter significado o fim das fronteiras e dos territórios nacionais, que ainda são elementos importantes para a circulação postal, como será demonstrado mais adiante. $\mathrm{Na}$ prática, os conflitos entre a autonomia nacional e a sujeição à ordem internacional em favor de uma maior fluidez não desapareceram, tampouco foi alcançada a plena uniformização das tarifas e dos procedimentos. O território postal único é antes um projeto que um fato realizado, devendo ser compreendido como parte do ideário da globalização. Como desvendou Octávio Ianni ([1995] 2010a, p.212) a respeito das falácias da globalização, “o mundo se transforma em território de todo o mundo", dando a falsa impressão de fim das fronteiras e também das desigualdades.

Essas ações globalizantes somente podem ser compreendidas com a sua contrapartida, ou seja, as iniciativas de regionalização que coexistem à UPU. Para Ianni ([1996] 2010b, p.101), a tensão instalada entre o nacionalismo, de um lado, e o globalismo, de outro, gera o regionalismo em sua versão atual, como uma "solução para os impasses e aflições do nacionalismo". O agrupamento de países em blocos regionais de interesse comum se revela como uma estratégia possível de enfrentamento à globalização e à forma hierárquica como ela está estruturada. Assim, a criação da União Postal Sul-Americana, já em 1907, quando o Brasil e outros países do continente articulavam o início de uma integração regional ${ }^{53}$, é uma expressão inicial desse conflito, que nunca pôde ser anulado por uma organização supranacional em escala mundial. No ano de 1911, foi instituída a União Postal das Américas, Espanha e Portugal (UPAEP), com participação do Brasil e outros vinte e cinco paísesmembros. Posteriormente, essas associações foram incorporadas ao funcionamento da UPU, servindo inclusive como fóruns regionais para o debate de propostas e incentivo à implementação de políticas comuns. Mais recentemente, note-se a criação da Associação dos Operadores de Correios e Telecomunicações dos Países e Territórios de Língua Oficial Portuguesa (AICEP), em 1998, também com a participação do Brasil. Outros exemplos semelhantes que merecem destaque são: União Postal Africana (UPA), de 1961; União Postal do Sul e do Sudoeste da Ásia (UPSOA), criada em 1977 e reativada em 1988; União PanAfricana de Correios (UPAP), desde 1980; Comissão Permanente Árabe de Correios (CAPP), de 1992; Associação dos Operadores Postais Públicos Europeus (POSTEUROP), criada em 1993; União Postal do Caribe (UPC), de 1998 (MONTGOMERY, 2002).

\footnotetext{
${ }^{53}$ Conforme item 1.4, sua posterior repercussão no Brasil foi a criação de linhas aéreas ligando o país à Bolívia, ao Paraguai e outros países vizinhos.
} 
Como nem sempre as tarifas internacionais acordadas no seio da UPU beneficiam a totalidade dos países, essas associações e uniões regionais acabam por se impor aos ditames externos por meio da criação de tarifas regionais privilegiadas. No âmbito de um mercado postal global, os países que exportam mais correspondências do que as importam, notadamente aqueles que se encontram no centro da economia capitalista, sedes de empresas, agências de notícias e instituições responsáveis por alimentar parte significativa do fluxo postal, encontram-se em larga vantagem, uma vez que os custos de entrega ficam por conta dos países de destino. A existência dessas formas regionais de cooperação denota o conflito entre os interesses nacionais e as políticas globais, sendo ao mesmo tempo uma forma de resistência e parte integrante da globalização.

O território postal único foi uma tentativa exitosa de globalização dos serviços postais. Os acordos permitiram a configuração de uma rede verdadeiramente global de circulação, com a garantia mínima de comunicação para as populações das mais diversas partes do planeta, além de ter ampliado a universalização dos serviços e contribuído para a aceleração do tempo de entrega. Por outro lado, a uniformização dos padrões e práticas impostos aos países gerou uma dupla dependência: tecnológica, desde a adoção do padrão inglês do selo até a importação, pelos países mais pobres, de máquinas e equipamentos oriundos principalmente da Europa Ocidental e dos Estados Unidos; e científica, com a crescente necessidade de consultorias e apoio técnico para a utilização das novas tecnologias, serviço prestado inclusive pela própria UPU ${ }^{54}$. Contraditoriamente, a globalização do correio por meio de um "território postal único" não significou a superação das desigualdades geradas no seio da divisão internacional do trabalho.

Os correios de todo o mundo vêm passando por profundas e sucessivas transformações nas últimas décadas, impactando desde sua forma de organização e regulação até as técnicas utilizadas e sua escala de ação. O estudo empreendido por Montgomery a respeito da UPU e o correio na escala mundial concluiu que

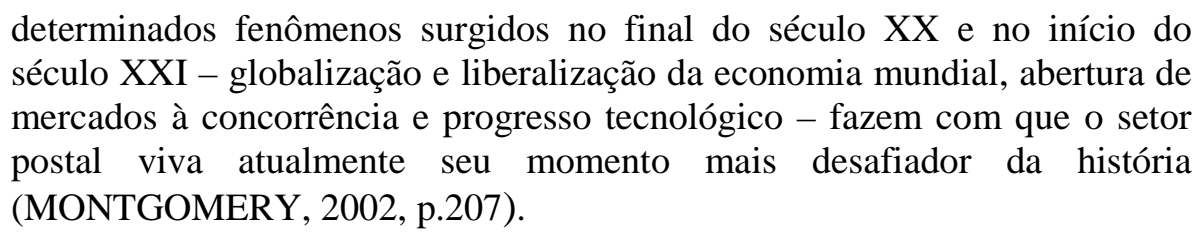

Essas mudanças de cunho técnico e político que impactam o setor postal são concomitantes e assinalam uma nova fase do correio em escala mundial. Elas podem ser entendidas tanto

\footnotetext{
${ }^{54}$ Os itens 1.3, 1.4 e 1.5 apresentam vários exemplos de dependência externa do correio brasileiro ao longo de sua história.
} 
como uma resposta do setor postal à globalização em voga e como parte integrante desse mesmo processo, pois se o correio fora profundamente afetado pelas novas variáveis do período, fora também através de suas ações que parte do que hoje chamamos de mundo globalizado pôde se constituir. Poderíamos, portanto, elaborar uma distinção simples, mas didática, entre o correio como fora tradicionalmente conhecido e sua versão mais moderna (Quadro 4), fruto de uma atualização correspondente aos impactos exercidos pela globalização em seis dimensões: organizacional, normativa, técnica, operacional, temporal e escalar.

\begin{tabular}{lll} 
DIMIENSÃO & CORREIO TRADICIONAL & CORREIO MODERNO \\
\hline ORGANIZACIONAL & Empresa pública & Empresa privada \\
\hline NORMATIVA & Regulação rígida & Regulação flexível \\
\hline TÉCNICA & Tratamento manual & Automação \\
OPERACIONAL & $\begin{array}{l}\text { Coleta, tratamento, } \\
\text { encaminhamento, entrega }\end{array}$ & Logística \\
TEMPORAL & Prazos rígidos (dias) & Just in time \\
ESCALAR & Nacional & Mundial
\end{tabular}

Quadro 4 - Principais diferenças entre o correio tradicional e o correio moderno.

Fonte: Elaboração própria, a partir de matriz de eventos, revisão bibliográfica e trabalho de campo.

Obviamente que as mudanças elencadas não se deram de maneira isolada, sendo antes fruto da determinação de umas sobre as outras. Também é preciso ressaltar que elas não afetaram todos os países de maneira homogênea, sendo a sua combinação diferente a depender de como essas dimensões se relacionam com as variáveis internas a cada formação socioespacial. Por fim, as mudanças fazem parte de um processo mais amplo de modernização que ainda está em curso, sendo possível encontrar características do correio tradicional (velho?) comparecendo nas práticas do correio moderno (novo?), descartando assim qualquer possibilidade de leitura anacrônica dos eventos e de seus efeitos.

$\mathrm{Na}$ dimensão organizacional, as tradicionais empresas públicas de correio foram cedendo lugar às empresas privadas, seja por meio da coexistência de ambas as formas ou pelo desaparecimento das primeiras. A execução do serviço postal pela iniciativa privada não é novidade na história do correio; observem-se os exemplos do controle exercido pelas famílias Tasso, na Itália (BRAUDEL, [1966] 1983), e Matta, para o caso de Portugal (ROSÁRIO, 1993), de onde descenderam a maioria dos correios-mores lusitanos. Também é 
possível encontrar na história brasileira casos de eventual surgimento de empresas privadas de correio (ver item 1.4), embora de âmbito estritamente regional e atuação reduzida. No entanto, esses casos correspondiam a concessões públicas para a prestação do serviço, que o Estado soube bem interrompê-las quando conveniente. Na atualidade, as empresas privadas operam em concorrência com as públicas, muitas vezes inviabilizando a continuidade do investimento estatal.

De fato, somente a partir da segunda metade do século XX o mercado encontrou condições atrativas para o investimento no setor postal em larga escala. O elevado custo dos transportes, aliado às incertezas de retorno dos lucros e o valor praticamente imutável dos preços praticados, faziam com que o Estado fosse o único agente capaz de assumir a iniciativa. A noção de que o correio era um serviço público também pouco questionava a organização dos serviços num nível macro. A transformação do objeto postal em mercadoria a partir da adoção do selo não foi suficiente para o surgimento de grandes investimentos privados. É justamente quando os territórios são dotados, pelo Estado, de uma infraestrutura de transporte terrestre, marítimo e aéreo que permitiu maior fluidez e o barateamento dos custos unitários, após a Segunda Guerra Mundial, que o mercado irá se aproveitar das novas condições de lucratividade.

Nesse contexto, surgem empresas privadas com investimentos e alcance semelhante às públicas, que mais tarde estenderiam suas redes por todos os continentes. Todas essas iniciativas foram formuladas no país que, durante a década de 1960 e, principalmente, 1970, reunia as condições econômicas, técnicas e políticas para que essa mudança pudesse se processar. Nos Estados Unidos, país que assumiu indubitavelmente a hegemonia militar e econômica no mundo pós-guerra, o mercado reagiu ao tradicional correio público com a invenção da grande corporação privada de correio, expressão mercadológica da globalização. Nasciam, assim, as empresas Federal Express, United Parcel Service e DHL.

As empresas privadas já nasceram com foco em serviços rápidos, que são também os mais lucrativos, como demonstra o próprio epíteto escolhido para nomear uma delas express $^{55}$. A invenção desses novos serviços de correio pela iniciativa privada também foi beneficiada pelos investimentos estatais de infraestrutura que ampliaram sobremaneira a rede de aeroportos e autopistas, bem como a capacidade dos portos. Com prazos determinados de entrega, os serviços expressos passaram a oferecer soluções de correio para um mercado corporativo, que inclui contratos mais duradouros e lucros avantajados. Quanto ao tipo de

\footnotetext{
${ }^{55}$ Em português, a palavra pode ser traduzida para "expresso".
} 
objeto postal, elas se concentraram no segmento de encomendas - como também revela a palavra que dá nome para outra delas, parcel $^{56}-$, que passaram também a ser mais lucrativos que as tradicionais cartas.

As empresas e departamentos públicos de correio são, todos eles, nacionais - em seu controle e administração, quanto à origem dos capitais investidos e em sua área de atuação. Já as empresas privadas ampliaram suas ações, em poucos anos, para além das fronteiras dos Estados Unidos, revelando seus interesses de mercado na escala mundial. Essas ações assinalam, assim, a passagem de um correio organizado exclusivamente em torno de empresas públicas nacionais para uma nova forma de organização, que inclui empresas privadas multinacionais. As multinacionais são compreendidas como grandes empresas com origem nacional, fruto de um longo e complexo processo de concentração e centralização de capital, em geral atuando sob a forma de um holding em escala mundial (CHESNAIS, 1996). Todas essas características - tamanho, origem, capital, atuação e escala - são encontradas nas três empresas que estamos considerando neste estudo, que são as maiores do setor postal privado. Além da concentração de capital necessário na fase inicial da empresa multinacional no país de origem, a continuação desse processo pelos países que se tornam novos mercados constituiu uma forma contemporânea de drenagem de lucros e, consequentemente, de aumento da concentração.

A entrada desse novo ator - a empresa multinacional de correio - alterou as relações entre os países, que até então estavam pautadas pela cooperação. O comando externo das ações, o surgimento de novos serviços e a uniformização dos procedimentos frequentemente escapam ao controle dos países, que passam a lidar com a competitividade em dois níveis: o interno ao território nacional, pela concorrência aberta entre a empresa pública nacional e as empresas multinacionais pelos mercados mais vantajosos; e o externo, que se dá entre as empresas públicas nacionais na corrida pela introdução de novos procedimentos e tecnologias que resultem em modernizações. Essa reorganização trouxe profundas consequências para a divisão internacional do trabalho no correio, com vantagens para os países-sede das empresas multinacionais.

O Brasil respondeu de maneira diferente à reorganização do setor postal em torno de empresas privadas (vide item 1.5). Enquanto surgiam inciativas desse tipo nos Estados Unidos, a novidade era mesmo a criação tardia da ECT e a constituição de uma empresa pública, com fortes impactos sobre a produtividade e a eficiência do correio, como apontado

\footnotetext{
${ }^{56}$ Em português, a palavra pode ser traduzida para "pacote".
} 
por Barros Neto (2004). Durante a década de 1970, quando as empresas multinacionais ampliam suas redes e consolidam efetivamente sua posição nos mercados nacionais, controlando uma rede privada de fluxo postal com pontos articulados em todos os continentes, para o Brasil o mercado externo se apresenta como uma via moderna de funcionamento e organização do correio, mas com ameaças ao mercado interno e à integração territorial que se consolidava durante a década de 1970.

No que tange ao aparato normativo, uma rodada de mudanças na regulação do setor postal, impulsionada pelos organismos supranacionais e pelo receituário neoliberal, fragilizou as antigas estruturas das empresas estatais, levando a falências, privatizações, aquisições ou concorrência desigual. A entrada em cena da empresa multinacional trouxe repercussões sobre os agentes que assumem uma função regulatória, antes exercida exclusivamente pelo Estado. De fato, esse agente corporativo adquiriu tamanha importância que passou a "regular determinados âmbitos da vida em sociedade, produzindo normas jurídicas, autonomamente ou em conjunção com o poder soberano" (ANTAS JR., 2005, p.173). Exercendo tamanha força sobre o Estado, as corporações privadas passaram a influenciar as normas e legislações por meio de um lobby eficiente.

A abolição das restrições normativas favoreceu enormemente as empresas privadas. Segundo analisou Harvey ([2005] 2014, p.34), “a desregulação de tudo - de empresas aéreas e de telecomunicações ao sistema financeiro - abriu novas áreas de liberdade de mercado irrestrita para poderosos interesses corporativos", com desvantagens para os investimentos estatais. Na prática, a desregulação não significou sempre a ausência de regulação, mas a produção de normas que correspondem ao interesse das empresas, sob a ideia de livremercado e livre-concorrência, que gerou mais concentração de capital e privilégios monopolísticos para as empresas multinacionais.

Para o correio, o caso de flexibilização da regulação ocorrido nos Estados Unidos foi emblemático. Em 2 de novembro de 1977, o congresso daquele país promulgou a lei pública 95-163, que aboliu as restrições concernentes ao transporte aéreo de carga. Ainda que essa mudança normativa não aparente relação direta com o setor postal, naquele momento era tudo o que as recentes empresas privadas precisavam para articular uma rede, inicialmente nacional e posteriormente internacional, de serviços postais expressos, conectando os centros de negócios mais relevantes. Como consequência, a lei autorizou as companhias regionais a operarem nacionalmente, oferecendo entregas rápidas com grande capacidade de transporte. Esse evento foi largamente comemorado pelas empresas, tendo merecido o título do relatório 
anual da FedEx Corporation em $1978^{57}$. Segundo o documento, a eliminação das restrições regulatórias governamentais para a circulação dos objetos significava uma nova fase para a empresa, que agora passaria a selecionar rotas e operá-las com aeronaves de todos os tipos e tamanhos, permitindo à companhia oferecer o serviço em grandes áreas de mercado com maior eficiência ${ }^{58}$. A regulação mais flexível nos EUA trouxe consequências para os demais países, pois a conquista do mercado interno pelas empresas e sua subsequente capitalização foi uma etapa essencial para a posterior expansão dos investimentos em escala mundial.

$\mathrm{Na}$ Europa, o mesmo procedimento de liberalização dos transportes como etapa necessária para a liberalização dos serviços postais foi detalhadamente estudado por Masutti (2002). No entanto, como afirma a autora, a noção de serviço postal universal é um limite à aplicação de normas de livre-concorrência, estabelecendo-se aí uma contradição entre as duas políticas, com desdobramentos nos conflitos atuais. Aguilar Pérez (2008) explica o processo de transformação de redes postais nacionais em redes transnacionais por meio da liberalização dos mercados de correio no âmbito da União Europeia, com privilégio para grandes empresas privadas como a DHL.

O Brasil optou por seguir na contramão da conjuntura internacional. Um ano após a mudança na regulação estadunidense, o país promulgou a Lei Postal (lei 6.538/78), que instituiu o monopólio da União sobre os serviços (vide item 1.5), como uma medida de proteção do Brasil face à concentração de capital e controle externo do correio, que já se revelava nociva à economia e soberania dos países periféricos da economia capitalista. A ação do Estado brasileiro foi claramente preventiva, num momento em que as orientações e incentivos dos agentes externos eram favoráveis à abertura dos mercados nacionais, que se consolidou em muitos países anos mais tarde, ao menos para o setor postal. Evidentemente essa decisão não é eterna nem está livre de conflitos, a exemplo dos dois projetos que disputam a condução de uma política para o setor postal brasileiro (vídeo item 1.6) - um voltado para o fortalecimento das instituições nacionais e outro de cunho claramente neoliberal.

\footnotetext{
${ }^{57} \mathrm{O}$ título do referido relatório é "deregulation drives growth", podendo ser traduzido para desregulação orienta $o$ crescimento. O documento é público e encontra-se na página da empresa na Internet, no endereço http://investors.fedex.com/financial-information/annual-reports/

58 "One of the most exciting and beneficial developments during the year was the Congress' enactment, on November 2, 1977, of Public Law 95-163, which substantially deregulated domestic air-cargo transportation. Virtually eliminating all government economic regulation of the movement of goods by air in the continental United States, this Law permits Federal Express, and other all-cargo air carriers, to select routes and set rates at the discretion of management. Services may be conducted with aircraft of any size or type.

Removal of aircraft size restriction has permitted the Company to purchase ten Boing 727's to serve larger market areas more efficiently, while freeing the smaller Falcon Express jets for expansion into new cities" (Federal Express Annual Report, 1978, p.4).
} 
Uma mudança técnica significativa nas últimas décadas foi a substituição do trabalho manual por processos operacionais executados por meio de dispositivos mecânicos e eletrônicos que desempenham funções correlatas, o que afetou a rotina de atividades desempenhadas pelo correio desde as agências de postagem até os centros de tratamento e triagem de objetos, levando ao aumento da capacidade de operação e da velocidade dos fluxos. A automação foi a mudança técnica mais relevante para o correio na segunda metade do século XX e, de alguma maneira, foi responsável pela uniformização dos padrões e procedimento em escala mundial. Para Oger (2000), as últimas décadas do século XX podem ser caracterizada pela prioridade de adaptação do correio às novas tecnologias.

É necessário realizar, aqui, uma distinção entre mecanização e automação. A mecanização remonta à Revolução Industrial e diz respeito à substituição do trabalho braçal por aquele realizado por máquinas, onde o trabalhador acompanha e realiza parte do processo. Um exemplo de mecanização no correio foi a introdução de máquinas de franquear no início do século XX, que substituíram o trabalho manual de aposição de selos nas cartas, permitindo a impressão de estampas postais numa série de envelopes em velocidade ampliada (ver item 1.4). Já automação, de acordo com Groover (2001), refere-se à conjunção da mecânica com a eletrônica e a informática, mediada por sistemas baseados em computadores. Logo, só é possível falar em automação a partir do desenvolvimento da microeletrônica por volta de 1950 e com a difusão das tecnologias de informação no processo produtivo das empresas, nas décadas de 1960 e 1970. A informação assume uma função primordial de suprir os equipamentos com um insumo necessário ao seu próprio funcionamento sem a necessidade de indução humana. Na automação, o trabalhador realiza apenas o acompanhamento do processo, pois o equipamento - o autômato - é capaz de identificar e mesmo aplicar algumas ações corretivas em casos de problemas e interrupções. Portanto, a automação distingue-se da mecanização principalmente por seu atributo informacional.

No correio, a máquina de triagem foi o objeto técnico que marcou a passagem para uma fase de automação. A partir da adoção dessa tecnologia, a triagem de objetos, principalmente pacotes, passou a ser realizada automaticamente, dentro dos grandes centros de tratamento, sem interrupção e de forma acelerada. A capacidade operacional das empresas de correio, tanto as públicas quanto as privadas, foi elevada significativamente. A máquina, 
contudo, depende de uma série de tecnologias informacionais que foram desenvolvidas antes de sua adoção, dentre as quais se destacam ${ }^{59}$ :

- implantação do código de endereçamento postal, o $\mathrm{CEP}^{60}$, produzindo uma racionalização do espaço por meio do uso lógico de numerações crescentes que contemplam informação de localização como a região, a cidade, o logradouro, etc.;

- utilização de etiquetas adesivas com código de barras nos objetos postais, fazendo com que a informação sempre esteja atrelada à correspondência. Assim, informações como tamanho, peso, volume, preço e principalmente o destino do objeto passaram de anotações manuais à sua versão digital;

- uso de leitores ópticos ou scanners para a decodificação das informações contidas nas etiquetas com códigos de barras, tanto nas unidades de postagem quanto nas unidades de tratamento e distribuição;

- adoção de computadores nas estações de trabalho, com o objetivo de realizar o processamento local das informações digitalizadas;

- construção de centros de processamento de dados, os CPDs, para o tratamento do volume crescente de informações e garantia da comunicação ininterrupta das diferentes unidades da empresa, que estão geograficamente separadas;

- conexão dos computadores à rede de dados online da Internet, de maneira a disponibilizar as informações também para o remetente e o destinatário.

Essas inovações operam de maneira integrada, em sistema, sendo uma indispensável ao funcionamento das demais. Essa constatação se assemelha àquela feita por Dicken ([1986] 2011), ao enumerar o que ele chamou de quatro tecnologias que tornam possível o moderno centro de distribuição: o código de barras associado a sistemas de software; esteiras rolantes de alta velocidade; scanners a laser com contêineres para recebimento de objetos; e computadores com capacidade avançada de processamento. Todas elas estarão reunidas na máquina de triagem, que realiza a identificação do CEP de destino do objeto por meio da utilização de leitores óticos que decodificam o código de barras e concomitantemente enviam as informações do objeto e o seu status no percurso por meio de computadores conectados à Internet. As recentes tecnologias de rastreamento de objetos são o corolário das mudanças

\footnotetext{
${ }^{59}$ Informaç̃oes adquiridas em trabalhos de campo realizados no Centro de Tratamento de Encomendas Jaguaré, em São Paulo-SP, em outubro de 2014 e março de 2015.

${ }^{60} \mathrm{O}$ código de endereçamento é denominado CEP, no Brasil; nos Estados Unidos adota-se a denominação zip code.
} 
técnicas, possível desde a conjunção do Código de Endereçamento Postal (CEP), do código de barras, dos computadores adaptados com leitores ópticos e interligados por rede de comunicação intra e internet.

No Brasil, a automação do correio foi implementada com certa defasagem, tendo alcançado primeiro os centros de tratamento e posteriormente as unidades de distribuição e postagem (ver item 1.5). Suas consequências puderam ser notadas mais contundentemente sobre a rotina do trabalho porque, como Bovo (1997) chama a atenção, esse processo significou a perda de autonomia do trabalhador sobre suas próprias atividades desempenhadas. No entanto, assinalamos que a automação do correio não afetou significativamente as tarefas de entrega, apesar da introdução de veículos motorizados, sendo esta a atividade que continua a absorver maior quantidade de mão-de-obra ${ }^{61}$. Se por um lado a automação acelerou os processos internos e reduziu sobremaneira o tempo de circulação dos objetos postais, a entrega continua a ser realizada por aquele que é historicamente o símbolo do correio - o carteiro ${ }^{62}$.

Para coordenar as ações possibilitadas pelo avanço técnico, a moderna logística empresarial foi introduzida no âmbito operacional do correio, garantindo maior racionalidade e acurácia às ações, confundindo o serviço postal tradicional com o serviço logístico, e aproximando o correio, entre outras funções desempenhadas, de um operador logístico. Por intermédio dessa reorganização estratégica das operações, as tradicionais etapas pelas quais uma carta ou encomenda passava foram integradas por meio da racionalização do processo de circulação. Na etapa da coleta, a postagem é realizada pelo remetente, geralmente via balcão de agência, e em seguida passa por uma separação preliminar conforme o destino e o tipo de objeto. Em continuação, no tratamento, a correspondência passa por uma triagem mais elaborada, que será decisiva para a determinação do modal de transporte e do tempo de entrega. Na terceira etapa, é realizado o transporte do objeto até a localidade de destino, obedecendo às exigências de acondicionamento e prazo. Por fim, na etapa da entrega, o objeto chega até o endereço de destino, geralmente pelas mãos de um carteiro.

\footnotetext{
${ }^{61}$ No caso brasileiro, por exemplo, do total de 117.405 funcionários dos Correios, 50,86\% deles são carteiros, o que equivale a um total de 59.718 pessoas. O segundo cargo que mais empresa na empresa é o de atendente comercial, lotado nas agências, correspondendo a $22,42 \%$ do total. No cargo de operador de triagem e transbordo (OTT) estão 11,70\% dos funcionários e outros cargos, incluindo todas as funções administrativas, 15,02\%. Esses dados são referentes ao mês de abril de 2016 e estão publicados na página da empresa na Internet, podendo ser acessada no endereço http://correios.com.br/sobre-correios/a-empresa/quem-somos/principais-numeros.

${ }^{62}$ Os testes feitos pelas empresas multinacionais para o uso de veículo aéreo não tripulado, comumente chamado de drone, na entrega de cartas e encomendas pode vir a afetar o trabalho dos carteiros a médio e longo prazo.
} 
Aqui, importa insistir na ideia que, com a mudança operacional sofrida pelo correio, as etapas de coleta, tratamento, encaminhamento e entrega passaram a ser coordenadas sob uma mesma estratégia logística e todo o processo começou a ser gerenciado numa mesma cadeia de distribuição, na qual a informação assume um papel central. Essa mudança operacional foi de suma relevância para compreender a aceleração do processo geral de circulação das mercadorias sob o capitalismo, aceleração essa que permite maior rapidez ao movimento do capital, uma vez que reduz o tempo no qual a produção se transforma em consumo, gerando lucros. Portanto, é na logística e na aceleração por ela proporcionada onde reside justamente a importância que assume o correio na atualidade, como intermediário do processo de circulação, elo de agentes dispersos pelo território.

Conforme abordado por Dicken ([1986] 2011), a logística tem se tornado uma atividade importante na globalização, especialmente por causa de: introdução de novos métodos de produção, envolvendo maior flexibilidade; mudanças nas relações entre clientes e fornecedores; incremento dos procedimentos de entrega just in time; aumento da complexidade geográfica e da extensão das redes. Esses aspectos mencionados passaram a fazer parte, de maneira crescente, da rotina de atividades desempenhadas pelas empresas de correio de uma maneira geral. A mudança operacional do correio significou, também, maior investimento em capital fixo, com a multiplicação dos centros de tratamento de carga dotados com máquinas de triagem. Com a logística, a circulação ganhou nova tônica para o correio: a possibilidade de realizar não somente o acompanhamento de todo o processo, mas inclusive a sua antecipação por meio da previsão do volume de objetos e do tempo das ações, assim como a sua posterior avaliação, graças aos relatórios gerados em relação às metas pré-estabelecidas.

É assim que no plano temporal foi possível diminuir o tempo de entrega de correspondências, que passou a ser contato em horas, fato inédito na história do correio. Essa diminuição ocorreu no bojo da inserção da logística aliada às práticas do chamado just in time, que para o correio significou a possibilidade de oferecer uma carteira de serviços diversos com prazos determinados de entrega. O just in time pode ser caracterizado pela adoção de métodos flexíveis de produção, em contraposição à rigidez típica do fordismo, pela redução dos custos de armazenamento/estoque e pelo suprimento contínuo em dias e horários pré-determinados (HARVEY, [1989] 2011). Essa mudança temporal foi importante porque faz parte de um processo mais amplo, de aceleração do próprio tempo de giro do capital e, portanto, reduzindo o tempo necessário à sua reprodução.

A adoção de práticas just in time deu origem aos chamados serviços expressos, com prazos flexíveis e o aumento do portfólio de serviços oferecidos. Se antes os serviços postais 
se baseavam na rigidez dos prazos contados em dias, a partir da década de 1970 foi possível oferecer serviços com a flexibilidade da escolha do horário de entrega. Neste sentido, é importante ressaltar a consideração feita por Dicken ([1986] 2011), para quem o tempo (da circulação, das entregas, da logística) se tornou a base da competitividade na globalização contemporânea. Já para Santos ([1996] 2012) não se trata somente de just in time, ou seja, do tempo exato das ações, mas a ele deve ser atrelada sempre a ideia de just in place, pois a localização exata também se tornou um imperativo e diferencial competitivo na atualidade. Para o autor, "é dessa forma que as noções de just in time e de just in place, indispensáveis a um desempenho exitoso, deixam de ser um projeto e se tornam atuantes" (SANTOS, [1996] 2012b, p.297). Destarte, fazer com que as cartas e pacotes cheguem ao local determinado na hora exata passou a ser um princípio de ação e um distintivo de competitividade entre as empresas de correio.

No Brasil, a criação do SEDEX pelos Correios no início da década de 1980 pode ser compreendida como um desdobramento desse rearranjo no tempo de circulação das correspondências (ver item 1.6). Com a passagem dos anos, a tendência se consolidou através da criação de variantes do serviço inicial, que passaram a incorporar maior flexibilidade de horários de entrega, que vão desde o mesmo dia da postagem até às $10 \mathrm{~h}, 12 \mathrm{~h}$ ou $18 \mathrm{~h}$ do dia seguinte. Em outros países é possível encontrar serviços semelhantes, inclusive aqueles prestados pelas empresas multinacionais.

Por fim, a escala de ação das empresas e os fluxos postais se tornam verdadeiramente mundiais, pois ainda que anteriormente já existissem serviços internacionais de correio, somente a partir das instituições supranacionais, principalmente a UPU, e das empresas multinacionais é que os fluxos passam a ser organizados e articulados numa mesma rede. Contudo, uma mudança na escala dos fluxos não significou necessariamente a superação das desigualdades no bojo da atual divisão internacional do trabalho, como já apontado, mas poderíamos ainda sugerir que elas foram mesmo aprofundadas, face à constituição de poderosas redes exclusivas de comando privado por parte das empresas multinacionais.

Para o Brasil, essa mudança na escala nos fluxos reverberou na incorporação progressiva de serviços internacionais pelos Correios, a exemplo do SEDEX Mundi. No que tange aos fixos necessários ao tratamento desses fluxos, note-se a criação, pelos Correios, de centros logísticos especializados em tratamento de carga internacional, por onde entram e saem os objetos postais com origem e destino no país, com exceção das redes das empresas privadas, que possuem seus próprios terminais. 


\subsection{Monopólio postal estatal versus monopólio privado}

Apesar das mudanças no correio na atual fase da globalização, coexistem arranjos de empresas nacionais controladas pelo Estado com empresas multinacionais de capital privado. Internamente, cada país dispõe de um aparato normativo próprio que regula a maior ou menor atuação de empresas privadas, nacionais ou estrangeiras, nos limites de seu território, conformando um quadro diversificado de situações na atualidade que pode ser generalizado sob três situações típicas: monopólio estatal total, monopólio estatal parcial e livre concorrência (Mapa 6). A situação atual não confirmou o que fora apregoado por Albon (1991) para o futuro dos serviços postais, cuja única via possível seria a extinção do monopólio estatal, a começar pelo Royal Mail do Reino Unido ${ }^{63}$.

Nos casos de monopólio total, o Estado é o provedor, com exclusividade, de todos os tipos de serviço postal, aí incluídos desde a tradicional carta - segmento mensagem - até os pacotes - segmento encomenda. A atuação de empresas privadas, nacionais ou estrangeiras, fica restrita aos serviços internacionais, ou seja, na prática as demais empresas só podem conectar pontos do país a outros destinos localizados fora dos limites nacionais, ficando o mercado interno reservado à ação da empresa pública. Cuba é um exemplo típico de país que se enquadra nessa categoria. Desde a lei n³508 de 1965, a Empresa de Correos de Cuba recebeu outorga do Ministério da Informática e Comunicações de Cuba para explorar com exclusividade a prestação de todos os serviços postais entre localidades do país, sendo que empresas estrangeiras, principalmente a DHL, oferecem apenas serviços internacionais. $\mathrm{Na}$ Bolívia, a Empresa de Correos de Bolívia (ECOBOL) também atua em regime de monopólio, ofertando mais de vinte categorias de serviços compatíveis com os atuais padrões de qualidade. Na África, os mercados de correio são totalmente controlados em países como Nigéria e Mauritânia; em Angola, mensagens e encomendas só podem ser enviadas, dentro do país, pela Empresa de Correios de Angola (UPU, 2016). A lista segue com Bielorrússia, Indonésia, Iraque, Síria, etc., sendo no geral constituída por países periféricos da economia capitalista, que protegem totalmente seus mercados internos da concorrência com as gigantes multinacionais.

\footnotetext{
${ }^{63} \mathrm{O}$ autor reconhece o prejuízo que a medida traria para regiões periféricas do país, como as áreas rurais, mas ainda assim defende uma política de compensação para o que ele denomina de perdedores do jogo: "Competition is not a zero-sum game - the benefits will outweight the losses allowing for the possibility of compensation of the losers" (ALBON, 1991, p.52)
} 


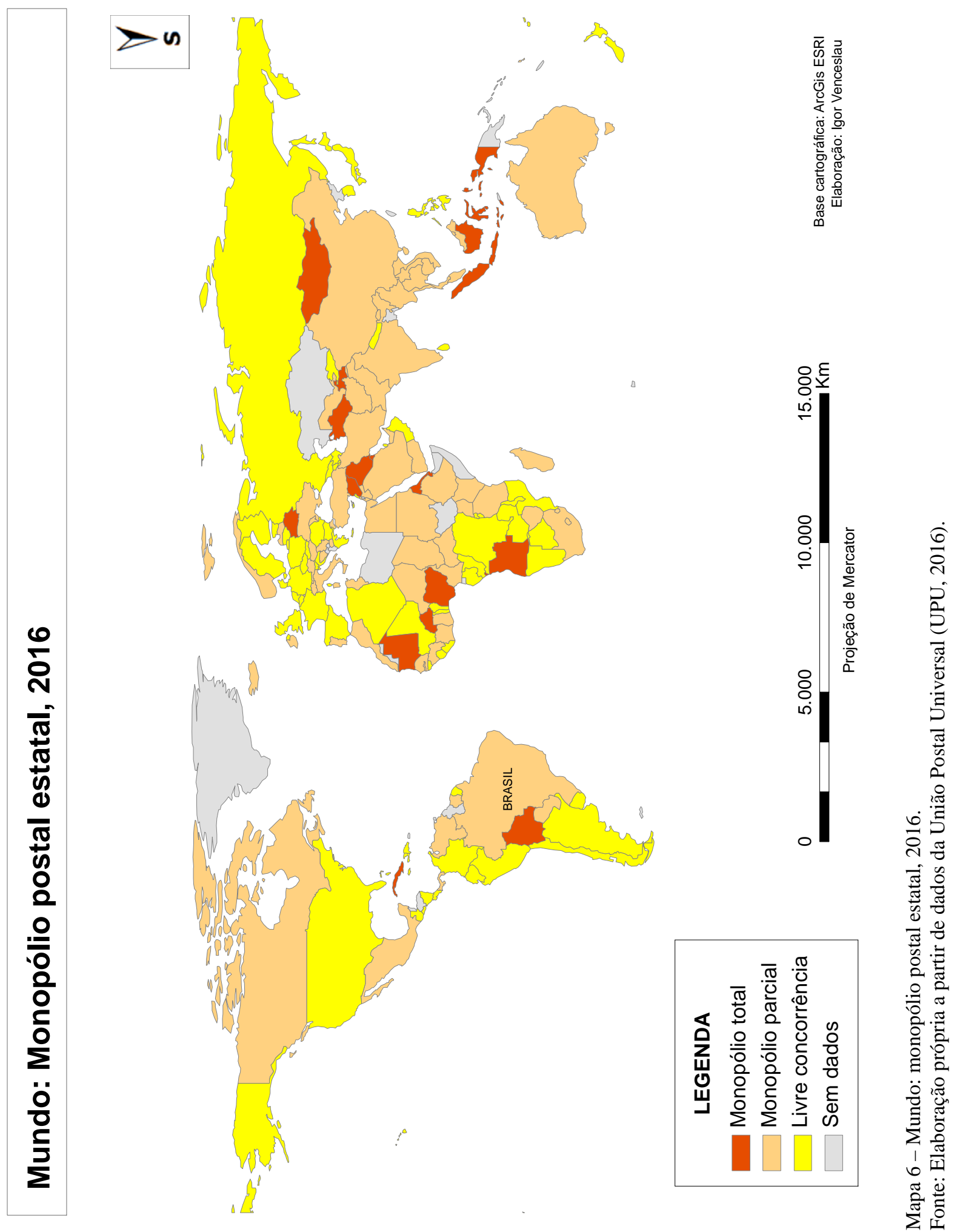


No grupo do monopólio parcial encontra-se grande número de países, inclusive o Brasil. Nesses, o Estado detém a exclusividade na prestação de apenas alguns tipos de serviço postal, operando os demais em regime de livre concorrência. Geralmente, como ocorre também no caso brasileiro, o monopólio se aplica aos serviços do segmento mensagem, incluindo caratas simples e registradas, telegramas e pequenos volumes que variam, de país para país, entre 50 gramas e 2 quilos. Nesses países, o Estado tem assumido a competência de resguardar a circulação das mensagens, oferecendo inclusive esse serviço em lugares onde o mercado não possui interesse em atuar. Mais lucrativo, o segmento encomenda, que inclui os pacotes que variam de 0,5 a 20, 30 e até 40 quilos a depender do país, não é protegido por monopólio, ficando a concorrência aberta entre a empresa pública, as multinacionais e eventuais outras empresas privadas existentes. Na América Latina, países como Paraguai, Venezuela e México praticam a proteção parcial de seus mercados postais. Um número razoável de países africanos também o faz, incluindo aí Egito, Marrocos, Quênia, Etiópia, entre outros. Essa é a situação predominante também nos países do sudeste asiático e do oriente médio. Mas esse tipo de proteção não é aplicada somente nos países periféricos da economia mundial. A Austrália e o Canadá adotam medidas semelhantes, o mesmo valendo para países europeus com desenvolvimento econômico mais tímido, incluindo Irlanda, Portugal, Hungria, países da ex-Iugoslávia e até a Itália. Com exceção da Rússia, os demais países do grupo denominado BRICS ${ }^{64}$ - Brasil, Rússia, Índia, China e África do Sul, adotam largamente o monopólio parcial dos serviços postais, revelando uma predominância de países periféricos e semiperiféricos nessa categoria, que realizam uma abertura controlada de seus mercados postais.

Por fim, há o grupo de países que não aplicam restrição ao mercado postal, podendo o serviço ser oferecido por qualquer empresa pública ou privada, nacional ou estrangeira. Em alguns casos, coexistem as empresas privadas com a empresa pública em regime de livre concorrência. É o que acontece nos Estados Unidos, onde apesar da reforma postal de $1970^{65}$ designar a empresa pública United States Postal Service como detentora de privilégio na prestação dos serviços, sua ação não é exclusiva e nem mesmo observada ou encorajada pelo Estado. No Japão, desde 2003 as empresas multinacionais competem livremente com a Japan Post Corporation Ltd., uma holding criada e controlada pelo Estado desde a fusão com a Japan Network Co. Na França, a reestruturação promovida pela lei 123 de 2010 abriu o

\footnotetext{
${ }^{64}$ A sigla BRICS equivale às iniciais em inglês dos nomes dos países designados - Brazil, Russia, India, China and South Africa.

${ }^{65} 1970$ Postal Reorganization Act (PRA).
} 
capital da estatal La Poste, sendo o Estado um dos acionistas, e estabeleceu a livreconcorrência naquele país. No caso da Alemanha, o Estado detém somente $25 \%$ das ações da Deutsche Post AG, sendo que o acionista majoritário é a empresa multinacional DHL (UPU, 2016). Em outros casos, a empresa pública foi privatizada e a prestação dos serviços é totalmente assumida pelo mercado. Em casos como a Libéria, ainda, não há empresa nacional na prestação dos serviços, que é oferecido majoritariamente pelas multinacionais. De maneira geral, a livre concorrência prevalece nos países centrais da economia capitalista, onde estão também as sedes das multinacionais de correio, e nos países periféricos que adotaram as políticas neoliberais de regulação flexível. No primeiro caso encontram-se, além dos já mencionados, países da norte do continente europeu, Espanha, Rússia, Coréia do Sul, Nova Zelândia e outros. No segundo caso, comparecem exemplos africanos, latino-americanos, países da Europa Oriental recém-ingressados na União Europeia e poucos asiáticos.

$\mathrm{Na}$ América Latina, especialmente, muitos países liberalizaram seus mercados de correio. A livre concorrência tem sido empregada no Chile desde o final dos anos 1980; na Colômbia, com a Constituição de 1991 e a lei 80 de 1993, o monopólio foi abolido; em 1995 foi a vez de a Nicarágua retirar o Estado do mercado postal; o Peru, por sua vez, abdicou de seu correio público em 2007 (UPU, 2016). O caso que se apresenta mais emblemático dos conflitos pelo controle do mercado postal é o da Argentina. A quebra do monopólio estatal e a consequente liberalização do mercado interno ${ }^{66}$ ocorreu em 1993. Quatro anos mais tarde, o correio daquele país foi totalmente privatizado ${ }^{67}$ e a empresa Correo Argentino S.A. passou a assumir os serviços, como apontado por Sidero (1997). Contudo, alguns anos depois o Estado encerrou a licença de prestação dos serviços pela empresa privada ${ }^{68}$ por meio do decreto 1075 de 2003, e criou a empresa pública Correo Oficial de la República Argentina S.A. CORASA, estabelecendo-a como provedor oficial dos serviços postais, que concorre no mercado nacional com mais de cento e quinze empresas privadas (UPU, 2016).

Na globalização, o antigo monopólio que assentava sob a figura do Estado passou a ser questionado e entrar em conflito com uma nova forma de monopólio, o privado. Os monopólios estatais nacionais são desencorajados e ameaçados pela concorrência que os transforma em monopólios internacionais privados, que organizam a circulação postal dos territórios desde pontos nodais corporativos localizados no hemisfério norte, de onde também partem o comando e os capitais investidos e para onde os lucros são posteriormente

\footnotetext{
${ }^{66}$ Essas ações ocorreram no governo do então presidente Carlos Menem.

${ }^{67}$ O correio público argentino foi adquirido em 1997 por empresa privada cujo dono é o atual presidente argentino, Maurício Macri.

${ }^{68}$ A ação foi uma política do governo do então presidente Néstor Kirchner.
} 
revertidos. Assim, o que está sendo proposto pelos arautos do neoliberalismo não é o fim dos monopólios, como eles próprios enganosamente declaram, mas a substituição de um monopólio público por um outro monopólio - o privado.

Contraditoriamente, a UPU, uma associação de cooperação entre organismos dos Estados, tem um papel ativo no incentivo à abertura dos mercados nacionais. Essa instituição deveria garantir a soberania dos países e o fortalecimento dos Estados no oferecimento do serviço postal, mas acaba por ser uma voz encorajadora de reformas postais que na prática significam a imposição de uma regulação flexível como regra. Segundo as próprias palavras da UPU na seção sobre regulação do documento intitulado Doha Postal Strategy ${ }^{69}$, que estabelece as diretrizes para o setor e orienta a ação dos países-membros nos anos 2013-2016, uma das ações do organismo deve ser conduzir uma reforma das regulações "ultrapassadas e desnecessárias"70 (UPU, 2012). A UPU tem estimulado a participação dos países em conferências realizadas anualmente em sua sede, na Suíça, cujo tema é a regulação postal. No último evento, acontecido em novembro de 2015, o tema já apontava claramente a posição do organismo das Nações Unidas quanto ao debate polêmico - a chamada naturalizava as mudanças políticas na regulação postal, associando-as a fenômenos da natureza: mudanças de ambiente necessitam de mudanças regulatórias ${ }^{71}$. A primeira parte do evento foi totalmente dedicada a apresentar as atuais experiências de privatizações no Japão, em Portugal e na Malásia $^{72}$. Assim, a união universal acaba por se confundir com incentivos à conformação de um mercado postal globalizado sob a égide do capital privado.

Somado às pressões da UPU pelas reformas há o lobby das empresas multinacionais pela quebra dos monopólios estatais. Ainda assim, países com expressivo mercado interno continuam a manter a proteção de seu setor postal, tanto por meio de seu aparato normativo quanto por suas empresas públicas. É o caso de países como Brasil, China, Índia, África do Sul e Turquia, que além de populosos têm demonstrado um forte crescimento econômico e a

\footnotetext{
${ }^{69} \mathrm{O}$ documento foi elaborado durante o $25^{\circ}$ Congresso da UPU em Doha, Catar, no ano de 2012. A UPU realiza eventos mundiais a cada quatro anos, quando estabelece as diretrizes para o próximo quadriênio. O último congresso foi realizado em Istambul, Turquia, entre os dias 20 de setembro e 7 de outubro de 2016, tendo estabelecido os seguintes objetivos para o quadriênio 2017-2020: 1) aperfeiçoar a interoperabilidade da infraestrutura em rede; 2) assegurar a sustentabilidade e produtos modernos; 3) fomentar o funcionamento efetivo do setor de mercado.

70 "Possible actions that could be undertaken by UPU bodies: (...) Drive reform of outdated and unnecessary regulation" (UPU, 2012, p.24)

${ }^{71}$ O título do evento 2015 UPU Conference on Postal Regulation foi "Changing environment and changing regulator needs - new approaches to postal regulation".

${ }^{72}$ A programação completa do 2015 UPU Conference on Postal Regulation pode ser acessada no endereço eletrônico: http://www.upu.int/uploads/tx_sbdownloader/programmePostalRegulationForum2015En.pdf.
} 
consolidação de seus mercados nacionais nos últimos anos, tornando-se alvos preferenciais da política de expansão das multinacionais de correio.

As empresas multinacionais de correio são atores recentes no mercado postal, no qual se destacam sobremaneira as empresas de capital norte-americano, tendo experimentado uma expansão significativa nas últimas quatro décadas. A FedEx Corporation foi criada no ano de 1971 em Little Rock, Arkansas, sob a nomenclatura de Federal Express, um ano após os EUA terem experimentado sua maior greve do correio, que ficou conhecida como a grande greve postal e teve como desdobramento ações por parte do Estado que levaram à subsequente reforma postal $^{73}$ e à liberalização dos mercados (WALSH, 1992). A FedEx já iniciou suas atividades com o lançamento de um novo produto no mercado, oferecendo serviços sensíveis ao tempo de entrega ${ }^{74}$ nas maiores cidades dos EUA. Foi a primeira vez que uma empresa de grande porte definiu seu nicho de mercado estritamente relacionado ao transporte de pacotes e pequenas encomendas num tempo recorde. Nasciam assim os chamados serviços expressos ${ }^{75}$, com entrega programada para algumas horas seguintes à postagem, que seriam replicados a partir de 1987 em praticamente todos os países por iniciativa da UPU sob a insígnia de Express Mail Service (EMS), modalidade oferecida pelas empresas públicas como serviço expresso internacional. Dois anos após sua fundação, a FedEx transferiu sua sede e as operações para a cidade de Memphis, Tennessee ${ }^{76}$, dada a melhor localização dessa cidade e a disponibilidade de infraestrutura de transporte fluvial, ferroviária, rodoviária e aeroviária no mesmo lugar. A nova localização permitiu à empresa, ainda naquele ano, expandir sua atuação ofertando o serviço expresso overnight ${ }^{77}$ para vinte e cinco das maiores cidades estadunidenses. Após dez anos de atuação em território nacional, a FedEx iniciou suas operações internacionais, começando pelo Canadá.

\footnotetext{
${ }^{73}$ O chamado Postal Reorganization Act, de 1970.

${ }^{74}$ A noção fica melhor anunciada no termo em inglês time-sensitive.

${ }^{75}$ Uma experiência anterior que levou o epíteto express foi a rede de transporte a cavalo que funcionou por dezenove meses, entre os anos de 1860 e 1861, ligando os estados de Missouri e Califórnia, nos EUA. O chamado Pony Express foi uma ousada tentativa de integrar, via correio, as costas leste e oeste daquele país, já que as ferrovias só haviam chegado até o centro, no Vale do Mississipi, naquela ocasião sendo mais rápido que o transporte marítimo, que tinha que contornar o continente americano. As operações do Pony Express foram encerradas assim que a rede de telégrafos venceu as Montanhas Rochosas e alcançou a cidades de Salt Lake City, no estado de Utah (WALSH, 1992). O que diferencia essa experiência do século XIX do serviço criado pela FedEx é a constatação de que, no primeiro caso, a novidade estava no modal de transporte, que da via marítima passava para a terrestre; no segundo caso, a novidade reside sobre o tipo de serviço criado, que o diferencia dos demais objetos postais.

${ }^{76}$ A sede da FedEx Corp. mantém-se em Memphis, TN até os dias atuais.

77 Serviço oferecido até os dias atuais, no qual a operação é toda realizada durante a noite e a encomenda é entregue na manhã do dia seguinte.
} 
Semelhantemente, a United Parcel Service (UPS) também nasceu nos EUA. Iniciando em 1907 com entrega de mensagens na cidade de Seattle, estado de Washington, a empresa em seguida passa a realizar a entrega de pequenos pacotes em outros destinos da costa do Pacífico, mas até então sua atuação era geograficamente restrita e os serviços pouco sofisticados. Contudo, a partir de 1975, no contexto da nova regulação do setor de transporte aéreo, a UPS adquire autorização para operar em todo o país, sendo a primeira empresa privada de entrega domiciliar a operar nos 48 estados contíguos ${ }^{78}$. A partir de então, a empresa passou a grande concorrente da United States Postal Service (USPS), empresa pública de correio, e da FedEx, oferecendo serviços expressos similares de entrega de envelopes e pacotes nos principais destinos do país e para o exterior, começando pelo Canadá. Na década de 1990, a expansão da UPS já havia alcançado todos os continentes.

A $\mathrm{DHL}^{79}$ é outra empresa de correio com alcance mundial. Também fundada nos EUA, iniciou suas atividades em 1969 transportando pacotes entre San Francisco, na Califórnia e Honolulu, no Havaí. Em seguida, a empresa se transferiu para a Alemanha, onde mantém sua sede até os dias atuais na cidade de Bonn. Diferentemente das concorrentes, a DHL já iniciou suas operações com foco no mercado internacional, tendo começado a servir as Filipinas em 1971 e posteriormente estabelecendo agências em Hong Kong, Cingapura e Japão. A partir da fusão com a Deutsche Post, a empresa se tornou o maior operador postal da Europa.

No entanto, há uma controvérsia a respeito da classificação dessas empresas. Seriam elas, de fato, empresas de correio? Em recente livro, a geógrafa Deborah Cowen (2014) se refere à Fedex, à UPS e à DHL como empresas de logística, as chamadas logistics providers. Do mesmo modo, Silva Jr. (2009), fala em “provedores de serviços logísticos”, referindo-se às mesmas empresas. Estudando os fluxos de longa distância e a atuação internacional dessas corporações, Bowen Jr. (2002) as definiu como integrators, pelo papel que elas desempenham como integradoras do transporte de carga nos modais aéreo e de superfície em escala mundial. Em sua tese sobre o transporte rodoviário de carga no Brasil, Huertas (2013) as considerou como empresas do ramo das transportadoras, enquanto Trevisan (2007) as qualificou como empresas de transporte expresso de cargas. Um autor como Dicken ([1986] 2001), debruçando-se sobre a importância da logística e das cadeias de distribuição na globalização, refere-se a elas como empresas de correio expresso; seriam as express couriers, nas palavras

\footnotetext{
${ }^{78}$ Correspondendo a 48 dos 50 estados dos EUA, com exceção do Alaska e do Havaí.

${ }^{79} \mathrm{O}$ nome da empresa é um acrônimo formado pelas iniciais dos nomes de seus fundadores - Dalsey, Hillblom e Lynn.
} 
do autor. Porteous (1999), comentando o trabalho de Wheeler e Mitchelson, diferencia o correio convencional do correio expresso, sendo que à FedEx foi atribuída essa última função ${ }^{80}$. Por fim, M. R. Silveira (2009), ao exemplificar a diversificação no oferecimento de serviços pela sincronização das cadeias de suprimento e aproveitamento de economias de escala no que o autor considera como quinta revolução logística, relaciona a função dessas empresas com aquela desempenhada pelo serviço SEDEX dos Correios.

Se essas multinacionais não pudessem ser entendidas como empresas de correio, por que sua ação estaria restrita pela regulação postal dos países? Também entre as empresas não há consenso a respeito de como elas próprias se definem. Ou estariam elas utilizando-se das vantagens de serem reconhecidas ora como transportadoras, ora como integradoras, ora como operadores logísticos e, somente quando conveniente, como empresas de correio? Em 1978, a FedEx se reconhecia como all-cargo air carrier $^{81}$, ou seja, transportador de todos os tipos de carga aérea. A DHL demonstra bem essa indefinição, pois o nome oficial da corporação é "Deutsche Post DHL group", onde "post" refere-se a "postal", enquanto a estratégia de marketing a promove como uma empresa de logística ${ }^{82}$. A própria UPU, em suas publicações oficiais, reconhece que essas empresas privadas são as concorrentes das estatais nos mercados nacionais ${ }^{83}$, relacionando-as no mesmo ramo de atividade. De fato, essas empresas oferecem serviços postais similares em suas características, nos preços e na variedade de destinos (Quadro 5).

\footnotetext{
80 "Wheeler and Mitchelson (1989) have used volumes of Federal Express mail items in the United States to identify the informational and control functions of particular cities. Express mail provides a useful measure of high-value information flow which is more likely to be related to business purposes than the volume of ordinary mail" (PORTEOUS, 1999, p.100).

81 Informação extraída do relatório anual da FedEx de 1978, disponível no endereço eletrônico http://investors.fedex.com/financial-information/annual-reports/.

${ }^{82}$ Conforme o slogan "Think logistics. Think Deutsche Post DHL", que apresenta o relatório anual da empresa em 2014, acessível no endereço eletrônico:

http://www.dpdhl.com/en/investors/financial_reports/annual_reports.html.

${ }^{83}$ Sobre a Libéria, por exemplo, a UPU reconhece as empresas DHL, FedEx, UPS, entre outras como operadoras de correio privado internacional: "Competition: International private couriers operate in the postal Market of Liberia (DHL, FedEx (Safeway Cargo), TNT, UPS, etc.)" (UPU, 2016). Sobre a Zâmbia, o documento relata a perda de mercado para as empresas privadas: "Large volumes of letter mails from corporate customers and utility companies have been lost to competitors such as DHL, Intavia, Mercury Post, Quick Post, etc. There is apparent need to review the existing postal law and establish a proper regulatory mechanism that will provide equitable ground for competition in the sector" (UPU, 2016). Para a Alemanha, o documento estabelece a empresa DHL como o operador designado para os serviços postais no país, assinalando que se trada de uma empresa de porte mundial: "Designated operator: (...) Deutsche Post DHL is active in letter mail, parcels, express and logistics markets around the world" (UPU, 2016).
} 


\begin{tabular}{|c|c|c|c|c|}
\hline EMPRESA & SERVIÇO & $\begin{array}{l}\text { PRAZO DE } \\
\text { ENTREGA }\end{array}$ & PREÇO (US\$) & $\begin{array}{l}\text { HORÁRIO } \\
\text { FLEXÍVEL }\end{array}$ \\
\hline \multirow[t]{2}{*}{ USPS } & Priority Express & 1 dia & 36.60 & Sim \\
\hline & Priority 2-Day & 2 dias & 7.15 & Não \\
\hline \multirow[t]{2}{*}{ FedEX } & Overnight (standard) & 1 dia & 72.24 & Sim \\
\hline & 2 Day & 2 dias & 35.12 & Não \\
\hline \multirow[t]{2}{*}{ UPS } & Next Day & 1 dia & 67.45 & Sim \\
\hline & 2nd Day Air & 2 dias & 26.64 & Não \\
\hline DHL* & - & - & - & - \\
\hline
\end{tabular}

Quadro 5 - Simulação de preços e prazos de entrega de empresas de correio com atuação nos EUA para a postagem de um pacote de $1 \mathrm{lb}$ (aprox. meio kg) entre as cidades de New York-NY e Los Angeles-CA, em janeiro de 2016.

Fonte: Elaborado a partir de dados disponibilizados nos páginas das empresas na Internet.

*DHL não opera entre as cidades simuladas. A partir dos EUA, a companhia oferece principalmente serviços internacionais.

Além do que a literatura especializada considera e daquilo que é divulgado pelas próprias empresas, advogamos que FedEx, UPS e DHL são empresas privadas de correio pelas características de suas atividades-fim, ainda que se reconheça que essas corporações multinacionais sejam de difícil classificação, pela diversidade de atividades que desempenham. Suas atividades básicas estão relacionadas ao que denominamos de logística postal (ver item 3.1), pelas características similares com as empresas públicas de correio: trata-se de diversas modalidades de serviços de entrega domiciliar dos segmentos mensagem - cartas, envelopes, impressos - e encomenda - pacotes -, com ou sem valor adicional, cujo limite máximo de peso é estabelecido em torno de 30 quilos, solicitado por pessoa física ou jurídica em agências (Fotografia 1) ou caixas de coleta (Fotografias 3 e 4), com a exigência da apresentação do código de endereçamento postal no ato da postagem, sujeitos a rastreamento ponto-a-ponto e sensíveis ao prazo de entrega realizada por trabalhador a pé ou em veículo motorizado (Fotografia 2) com frequência diária. 


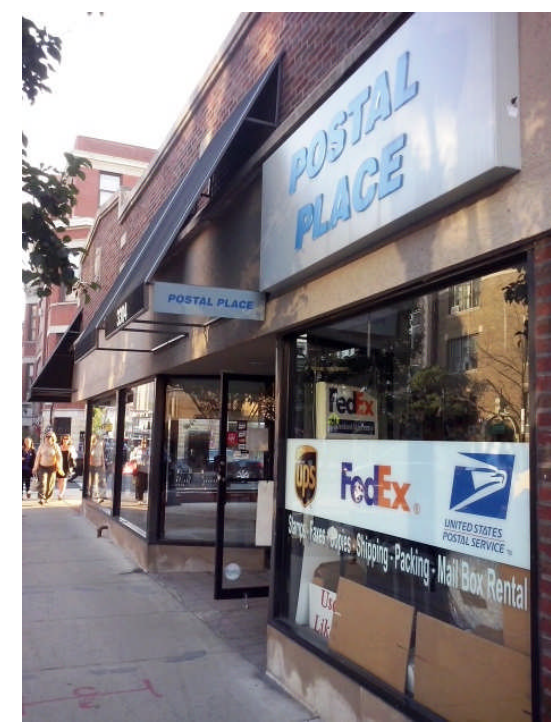

Fotografia 1 - Agência de postagem no bairro de Lakeview, Chicago-IL, EUA, expondo logomarcas de empresas pública (USPS) e privadas (UPS e FedEx) de correio.

Fonte: Trabalho de campo realizado em setembro de 2015.

Foto: Igor Venceslau

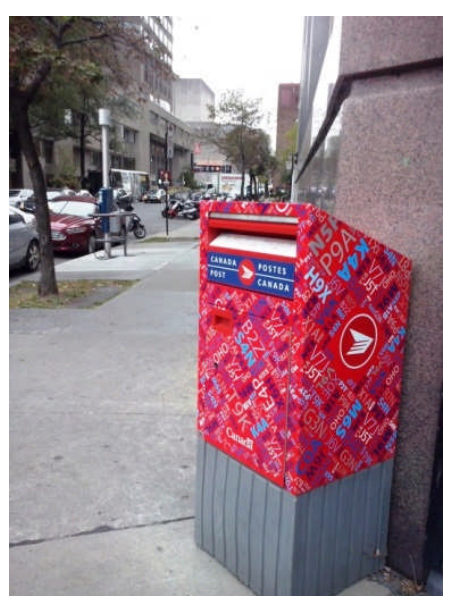

Fotografia 3 - Caixa de coleta para postagem de correspondências da empresa pública Canada Post/Postes Canada em logradouro da cidade de Montréal, Québec, Canadá.

Fonte: Trabalho de campo realizado em outubro de 2015.

Foto: Igor Venceslau

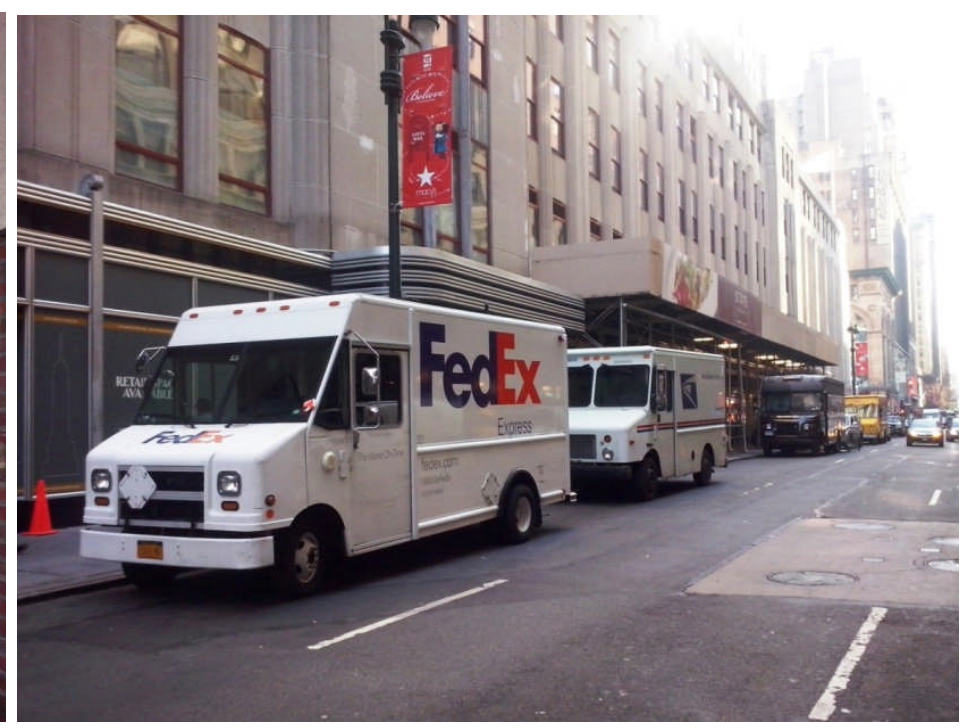

Fotografia 2 - Veículos de empresas de correio realizando entregas ao mesmo tempo no centro de Manhattan, New York-NY, EUA. Da esquerda para a direita: (1) FedEx, veículo branco; (2) USPS*, veículo branco; (3) UPS, veículo marrom; (4) DHL, veículo amarelo.

Fonte: Trabalho de campo realizado em dezembro de 2015.

Foto: Igor Venceslau

*empresa pública de correio dos EUA.

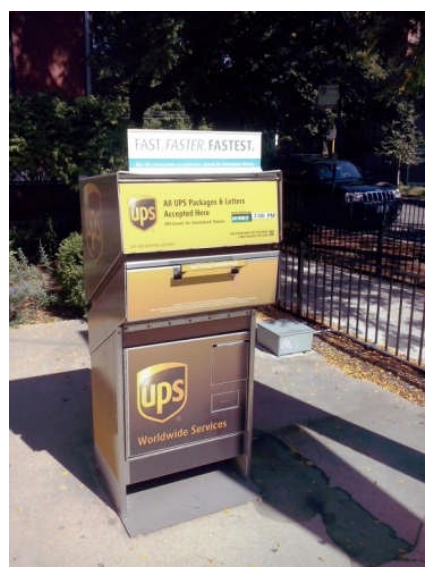

Fotografia 4 - Caixa de coleta para postagem de correspondências da empresa privada UPS em logradouro da cidade de Toronto, Ontario, Canadá. Fonte: Trabalho de campo realizado em outubro de 2015.

Foto: Igor Venceslau

A concentração do setor postal privado em um número reduzido de empresas sediadas nos Estados Unidos, União Europeia e Japão revela a divisão internacional do trabalho 
desenhada na nova conjuntura ${ }^{84}$. De uma situação de monopólios estatais nacionais, passa-se à conformação de monopólios privados de corporações multinacionais, cuja receita vem crescendo exponencialmente nos últimos anos, enquanto as empresas públicas que competem nos mesmos mercados vêm sua receita estagnar (Gráfico 1).

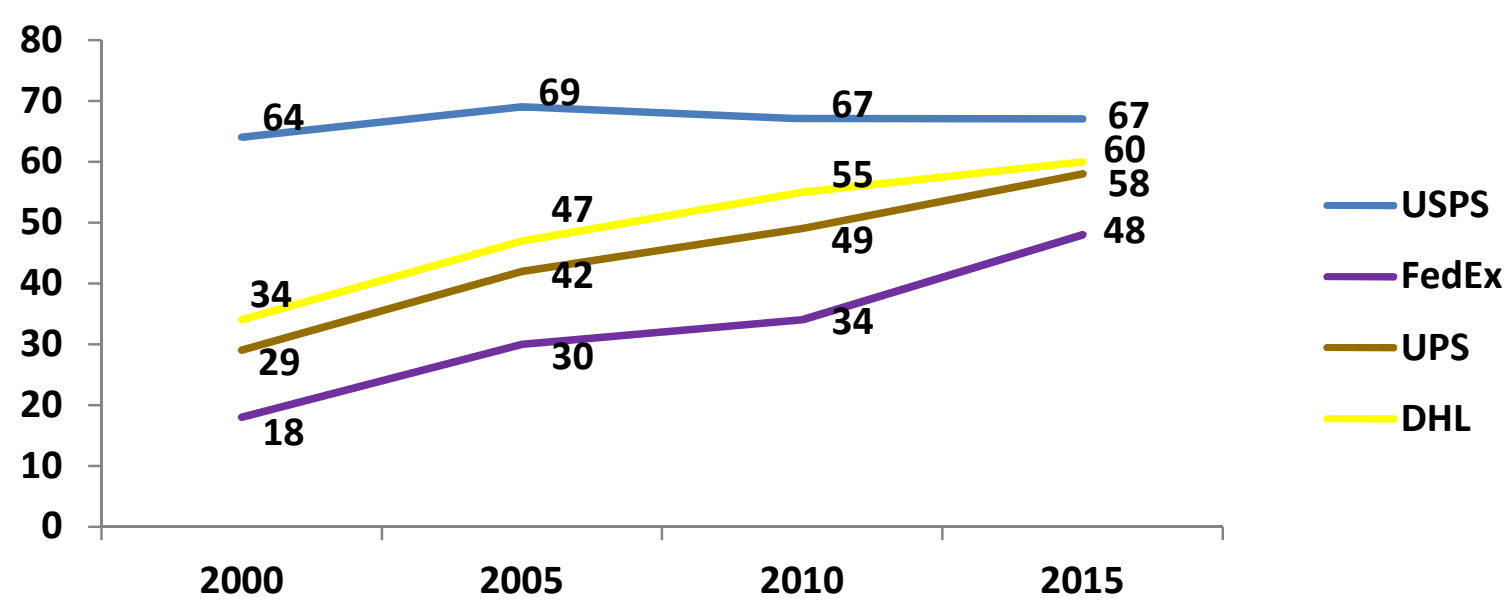

Gráfico 1 - Receita anual (entre 2000 e 2015) das principais empresas de correio que operam nos EUA, em bilhões de dólares.

Fonte: Elaboração própria com base nos relatórios anuais das empresas.

Em 2000, a empresa pública de correio dos EUA, a maior dentre as empresas postais estatais, tinha uma receita bastante superior às grandes multinacionais privadas, que já eram reconhecidas como tais naquela altura. A receita da USPS era praticamente duas vezes a de cada uma das demais tomadas individualmente. Em quinze anos, apesar de a USPS ter mantido seus níveis anuais de receita, as outras três companhias dobraram seus valores, se apropriando agora de cifras semelhantes à da empresa pública, com forte tendência a ultrapassá-la nos próximos anos. Colocadas em paralelo empresa pública e privada, os primeiros anos do século XXI parecem apontar para a consolidação de uma hegemonia da segunda sobre a primeira. O montante de dinheiro movimentado por cada uma delas em 2015 é superior ao PIB da maioria dos países. A receita da DHL, por exemplo, superou o PIB de cento e dezenove países, como Uruguai e Bulgária; a UPS é maior que cento e dezessete países, como Costa Rica e Croácia; a FedEx é mais rica que cento e sete países, como Panamá e Tunísia. É assombroso admitir que, se fossem países, essas empresas estariam nas posições $75^{\mathrm{a}}$ (DHL), 76 ${ }^{\mathrm{a}}$ (UPS) e $86^{\mathrm{a}}$ (FedEx) no ranking mundial de produto interno bruto ${ }^{85}$. Considerando apenas as três multinacionais privadas, em caso de uma futura fusão sob uma só

\footnotetext{
${ }^{84}$ Conforme dados da revista Fortune apresentados por Wood e Roberts (2011), das 100 maiores empresas do mundo em receita no ano de 2009, três delas são dedicadas ao setor postal: Japan Post Holding $\left(11^{\circ}\right)$, com US\$ 198 bi; Deutsche Post - DHL (54'), com US\$ 98 bi; US Postal Service $\left(84^{\circ}\right)$, com US\$ 74 bi.

${ }^{85}$ Dados do Banco Mundial para o ano de 2015.
} 
corporação, ela seria mais rica que cento e trinta e sete países e manipularia mais dinheiro que Hungria, Ucrânia, Marrocos ou Cuba. Olhando em retrospectiva para os primeiros anos de receita da FedEx Corp. é possível dimensionar o rápido crescimento que essa empresa vem obtendo (Gráfico 2).

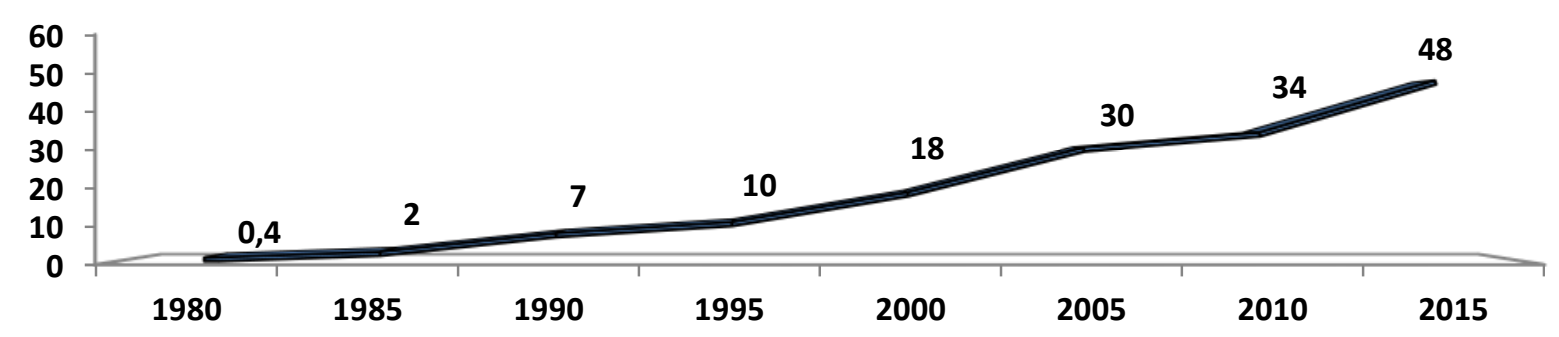

Gráfico 2 - Receita anual da empresa FedEx entre os anos de 1980 e 2015, em bilhões de dólares. Fonte: Elaboração própria a partir dos relatórios anuais da FedEx Corp.

Se a globalização dos fluxos postais pelas empresas públicas se pauta na cooperação entre elas, no caso das privadas o processo se dá via competição. A competição entre as empresas do setor privado evidencia o conflito pelo acesso aos mercados nacionais, principalmente nas modalidades de serviços expressos. No bojo do crescimento das multinacionais e da luta das estatais pela sobrevivência, verifica-se que o principal interesse assenta-se sobre o controle do monopólio da circulação de informações e mercadorias. Quem detém essa prerrogativa? Um exame dessa problemática deve contemplar questões da ordem da soberania nacional e da privacidade dos indivíduos, como a garantia da inviolabilidade das correspondências e a asseguração da universalidade na prestação dos serviços.

\subsection{Território e fronteira nacional na circulação de objetos postais}

Apesar da noção de território postal único disseminada pela UPU e da consolidação de empresas multinacionais de correio na fase atual da globalização, os fluxos postais não circulam à revelia das fronteiras nacionais, pois enfrentam o constrangimento das condições materiais e normativas dos territórios. Logo, o território impõe ritmos e condições diversas à circulação (ARROYO; CRUZ, 2015). É assim que nenhuma das redes das grandes empresas privadas de correio abarca a totalidade dos países e, mesmo aonde chegam, os alcança com defasagens. Também a diversidade do quadro normativo, com situações que vão desde o monopólio total à livre-concorrência, demonstra que estamos longe de verificar o fím das 
fronteiras e dos territórios nacionais. O caso brasileiro é emblemático da importância que continuam a ter território e fronteira nacionais para a realização da circulação global, como demonstra o monopólio estatal no país.

Ainda mais complexo é o caso da União Europeia (UE), onde coexistem e rivalizam territorializações distintas. Em primeiro lugar, há os correios nacionais com as distintas especificidades normativas dos países, onde na maioria deles ainda existem as respectivas empresas estatais. Em alguns deles, existem empresas regionais que de alguma maneira se opõem às empresas nacionais, como ocorre em País de Gales e na Escócia, no Reino Unido. A partir da criação da UE, a integração continental passou a afetar vários serviços, sendo que desde $2011^{86}$ foi abolido o monopólio entre os países-membros, embora nem todos tenham se adequado à nova diretriz por conta de adaptações internas necessárias. A alemã DHL obteve enormes vantagens a partir da flexibilização da regulação promovida no âmbito da UE, tendo assumido a função de prestador privilegiado de serviços postais entre os países. Num nível mais amplo encontram-se as normas e diretrizes produzidas pela UPU, onde cada país europeu possui um assento individual. Os conflitos interinstitucionais do setor postal dentro do bloco, como estudado por Eckert (2010), revelam que estamos distantes de falar em um único território postal, mas de territorialidades que ora se sobrepõem, ora se contrapõem.

Essas constatações estão de acordo com o que Dicken ([1986] 2011) considerou como dois tipos de "barreiras" ao movimento das coisas, especialmente no serviço de logística. O primeiro deles corresponderia às condições físicas de transferência de um modal de transporte para outro, como entre o terrestre e o aquático. O outro seria justamente relativo às complicações das fronteiras políticas, incluindo normas, tarifas e procedimentos diferenciados, que segundo o autor têm se tornado ainda mais relevantes conforme as atividades econômicas se globalizam.

Enquanto empresas públicas como os Correios, no Brasil, e a USPS, nos Estados Unidos, têm atuação nacional, oferecendo serviços internacionais por meio da cooperação com outras empresas nacionais no âmbito da UPU, as empresas privadas estão presentes em praticamente todos os países (Quadro 6). Além de se assemelharem em valor de receita anual e em número de empregados, essas empresas possuem uma estratégia competitiva que se caracteriza pela concentração de boa parte dos fluxos num ponto nodal privilegiado, operando por meio de um hub estratégico. No entanto, a administração tende a se localizar em outra cidade, correspondendo às capitais nacionais, nos casos das empresas públicas, e a centros

\footnotetext{
${ }^{86}$ Diretiva 2008/6/EC da União Europeia.
} 
empresariais e de negócios de relevância mundial, no caso das privadas - a exemplo de Atlanta $^{87}$, nos EUA e Bonn ${ }^{88}$, na Alemanha.

\begin{tabular}{|c|c|c|c|c|c|c|c|}
\hline EMPRESA & SEDE & $\begin{array}{l}\text { PRINCIPAL } \\
\qquad H U B\end{array}$ & $\overline{\text { FUND. }}$ & PAÍSES & $\begin{array}{l}\text { EMPREGADOS } \\
\text { aprox. (2015) }\end{array}$ & $\begin{array}{c}\text { RECEITA } \\
\text { aprox.(2015) }\end{array}$ & TIPO \\
\hline ECT & $\begin{array}{l}\text { Brasília-DF, } \\
\text { Brasil }\end{array}$ & $\begin{array}{l}\text { São Paulo-SP, } \\
\text { Brasil }\end{array}$ & 1969 & 1 & 117.000 & $\mathrm{R} \$ 18 \mathrm{bi}$ & Pública \\
\hline USPS & $\begin{array}{l}\text { Washington-DC, } \\
\text { EUA }\end{array}$ & Vários* & 1776 & 1 & 618.000 & US\$ $67 \mathrm{bi}$ & Pública \\
\hline FedEx & $\begin{array}{l}\text { Memphis-TN, } \\
\text { EUA }\end{array}$ & $\begin{array}{l}\text { Memphis-TN, } \\
\text { EUA }\end{array}$ & 1971 & 220 & 300.000 & US\$ $48 \mathrm{bi}$ & Privada \\
\hline UPS & $\begin{array}{l}\text { Atlanta-GA, } \\
\text { EUA }\end{array}$ & $\begin{array}{l}\text { Louisville-KY, } \\
\text { EUA }\end{array}$ & 1907 & 220 & 435.000 & US\$ $58 \mathrm{bi}$ & Privada \\
\hline DHL & Bonn, Alemanha & $\begin{array}{l}\text { Leipzig, } \\
\text { Alemanha }\end{array}$ & 1969 & 220 & 325.000 & US $\$ 60 \mathrm{bi}$ & Privada \\
\hline
\end{tabular}

Quadro 6 - Perfil de empresas públicas (ECT e USPS) e privadas (FedEx, UPS e DHL) de correio, 2016.

Fonte: Elaborado a partir dos relatórios anuais das empresas selecionadas.

*A USPS não centraliza suas operações, utilizando vários aeroportos regionais e redes de empresas privadas.

Por meio da análise de dados recentes do fluxo postal é possível dimensionar o mercado que está sendo disputado pelas multinacionais. As estatísticas divulgadas pela UPU ${ }^{89}$ para o ano de 2014 revelam que o volume total de correspondências no mundo foi da ordem de 334 bilhões de objetos, sendo que aproximadamente $98 \%$ corresponderam ao segmento mensagem (cartas, registrados, impressos, telegramas) e $2 \%$ ao segmento encomendas, que somou pouco mais de 7 bilhões de pacotes. Mesmo que as tradicionais cartas somem, de longe, o maior número absoluto de objetos, elas respondem por menos da metade do rendimento total do setor postal (Gráfico 3), demonstrando que as encomendas possuem maior valor agregado e constituem a fatia mais lucrativa dos serviços, justamente o nicho de mercado das multinacionais.

\footnotetext{
${ }^{87}$ Além da UPS, a cidade de Atlanta, EUA, é sede de empresas como a Coca-Cola, a AT\&T, a Delta Airlines, a CNN, a Home Depot e a Newell Rubermaid. O aeroporto Hartsfield-Jackson, que serve à cidade, é considerado como o mais movimentado do mundo em tráfego de passageiros.

${ }^{88}$ A antiga capital da ex-Alemanha Ocidental, Bonn, está no coração da megalópole do Vale do Reno, região industrial mais importante do país. Além da DHL, sedia empresas como Deutsche Telekom, Solar World e Haribo.

${ }^{89}$ Os números apresentados foram extraídos do site da UPU no endereço http://www.upu.int/en/resources/postalstatistics/about-postal-statistics.html.
} 


\begin{tabular}{|l|c|c|}
\hline \multicolumn{2}{c|}{} \\
\cline { 2 - 3 } \multicolumn{1}{c|}{$50,00 \%$} \\
\hline Cartas & 2014 & $100,00 \%$ \\
\hline$\square$ Encomendas & $41,80 \%$ & 2004 \\
\hline$\square$ Serviços financeiros & $19,10 \%$ & $50,70 \%$ \\
\hline$\square$ Outros & $17,10 \%$ & $9,70 \%$ \\
\hline
\end{tabular}

Gráfico 3 - Percentuais do rendimento total do setor postal por segmento de serviço nos anos de 2004 e 2014. Fonte: Elaboração própria a partir de dados da União Postal Universal.

A principal tendência dos últimos anos tem sido o crescimento do segmento de encomendas e diminuição das cartas. De acordo a historiadora Nancy Pope ${ }^{90}$, curadora do National Postal Museum, em Washington, DC, EUA, essa mudança que estamos vivenciando com o aumento das encomendas não diminui a importância cotidiana do correio, apesar de ser uma experiência diferente:

Nós identificamos o serviço postal de uma maneira bem diferente agora. Costumávamos ir à caixa de correio e dizer: "espero que eu tenha uma carta de um parente, talvez um cartão de Natal da vovó" [...]. Agora nós vamos à nossa caixa de correio e dizemos: "eu sei que meu pacote está aqui. O suéter que eu comprei está aqui!" Logo, nossa interação com o correio é muito diferente, mas ainda é importante. É apenas de uma maneira diferente (Tradução nossa) $^{91}$

Nos últimos vinte e cinco anos, o volume total de objetos do segmento carta apresentou uma queda que varia entre $12 \%$, para o serviço doméstico, e 55\%, para o internacional, aproximadamente. No mesmo período, o número de encomendas apresentou crescimento de mais de $200 \%$, tanto no âmbito nacional quanto internacional, revelando a tendência para o futuro. Vale salientar que, apesar dos esforços para a eliminação das barreiras aos fluxos postais globais nas últimas décadas, 98,6\% de todas as encomendas e 99\% de todas as cartas postadas em 2014 correspondem ao serviço doméstico, ou seja, sua origem e destino estão circunscritos aos limites de um mesmo país. Esse dado ajuda a compreender os interesses das multinacionais em adentrar os mercados de serviços

\footnotetext{
${ }^{90}$ Entrevista realizada em dezembro de 2015 no National Postal Museum, em Washington, DC, EUA.

91 "We relate the postal service in a very different way now. We used to go to our mailbox and say: 'I hope I have a letter from a relative, maybe a Christmas' card from grandma' [...]. Now we go to our mailbox and say: 'I know my package is here. The sweater I bought is here!' So, our interaction with mail is very different, but it's still important. It's just in a very different way."
} 
domésticos dos países. O termo postal society (sociedade postal) empregado por Henkin (2006) para os EUA no século XIX pode muito bem ser aplicado à situação atual de crescimento vertiginoso do fluxo postal no mundo.

No âmbito do correio privado, tampouco há território postal único: antes, trata-se de usos corporativos dos territórios. Usos, porque cada empresa o faz segundo os seus interesses e de maneira exclusiva; territórios, porque dependem da permissão dos Estados para a sua entrada e a definição da forma de sua atuação. Apesar de declararem presença em todos os países, essas corporações constantemente interrompem suas operações em alguns deles, de acordo com seus objetivos. Assim, há pelo menos dois anos a estadunidense UPS excluiu Sudão, Somália, Irã, Afeganistão e Coréia do Norte de sua rede, alegando que esses lugares são altamente perigosos para as suas atividades ${ }^{92}$. Coincidências com a lista de inimigos declarados dos EUA? Nem tanto. Até julho de 2016, apenas a alemã DHL servia Cuba, quando as estadunidenses receberam autorização para romper com o embargo imposto à ilha, sendo que a FedEx foi a primeira a iniciar suas operações ${ }^{93}$. A lista de países excluídos da rede da FedEx ${ }^{94}$ também contém o grupo dos não alinhados à política de Washington, incluindo aí a Síria, o Turcomenistão, entre outros.

Essas empresas multinacionais são veículos da globalização. Apresentando-se como transnacionais e globais, na verdade são multinacionais, ou mesmo internacionais pelo caráter extremamente nacional de suas ações e da topologia de suas redes e fluxos, concentradas nos EUA e na Europa Ocidental (Mapas 7, 8 e 9). Essas corporações são seletivas e atuam em pontos específicos dos territórios, mesmo nos EUA e UE, notadamente escolhendo os lugares economicamente mais lucrativos. Deste modo, sua atuação em rede não abarca todo o espaço, mas permite o controle centralizado dos fluxos e um uso corporativo do território. É o que tinha constatado Santos ([1993] 2006), a respeito da seletividade das redes, que não podem cobrir todo o espaço, nem substituir o espaço de todos, o espaço banal. Segundo Raffestin (1993, p.157), "toda rede é uma imagem do poder ou, mais exatamente, do poder do ou dos atores dominantes”. Expressão desse poder, nenhum nó principal dessas redes está localizado ao sul da Linha do Equador, revelando a repetição de uma tendência história da divisão internacional do trabalho - a hegemonia política e econômica dos países centrais do sistema capitalista.

\footnotetext{
${ }^{92}$ Informação adquirida em trabalho de campo realizado no maior centro de operações logísticas da UPS, localizado em Louisville-KY, EUA, em novembro de 2015.

93 Segundo informações de agência de notícias especializada no setor, acessada no endereço http://aircargoworld.com/fedex-first-u-s-cargo-carrier-to-service-cuba/.

${ }^{94}$ Disponível em http://www.fedex.com/gb/contact/served-countries.html. Acesso em setembro de 2016.
} 


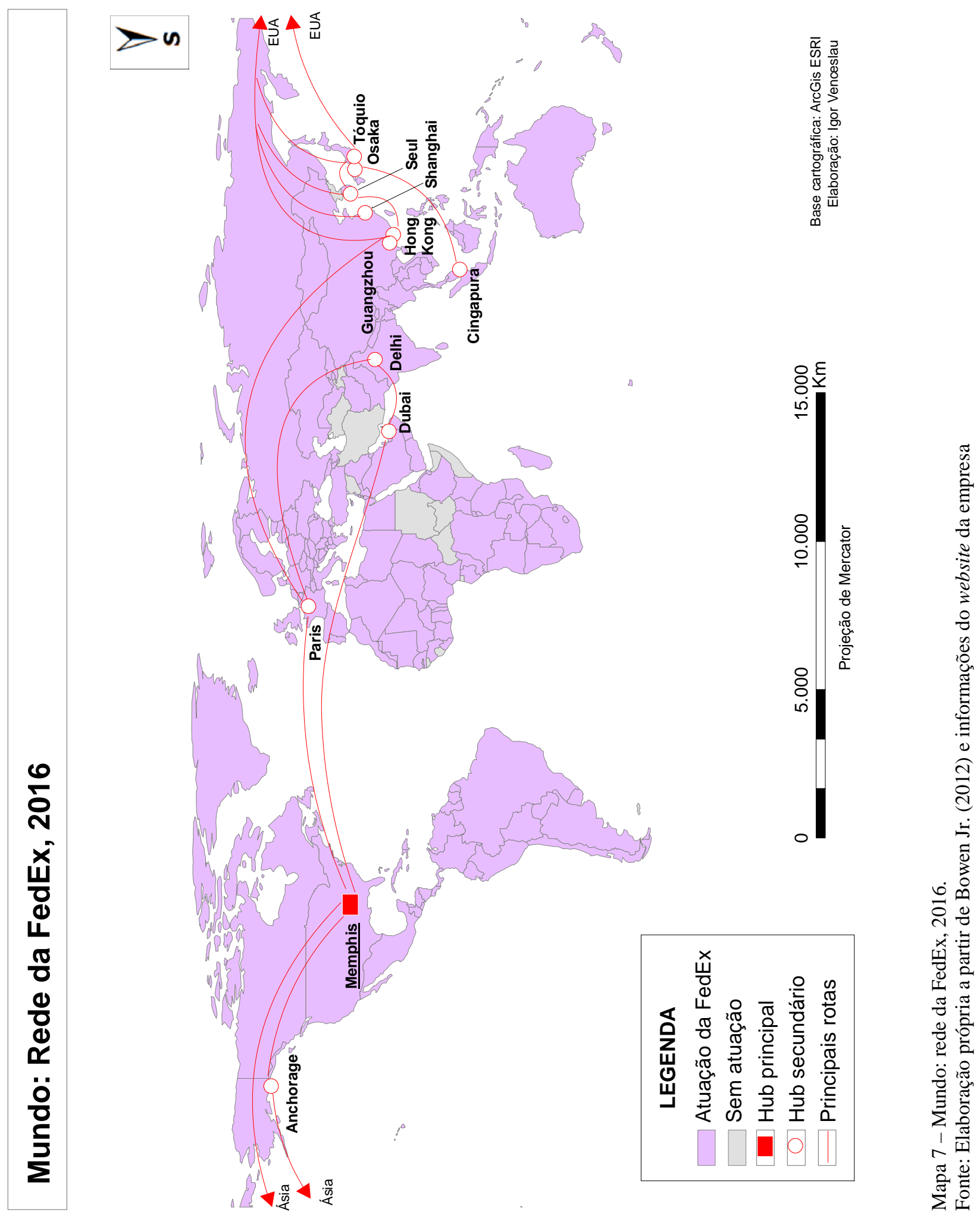




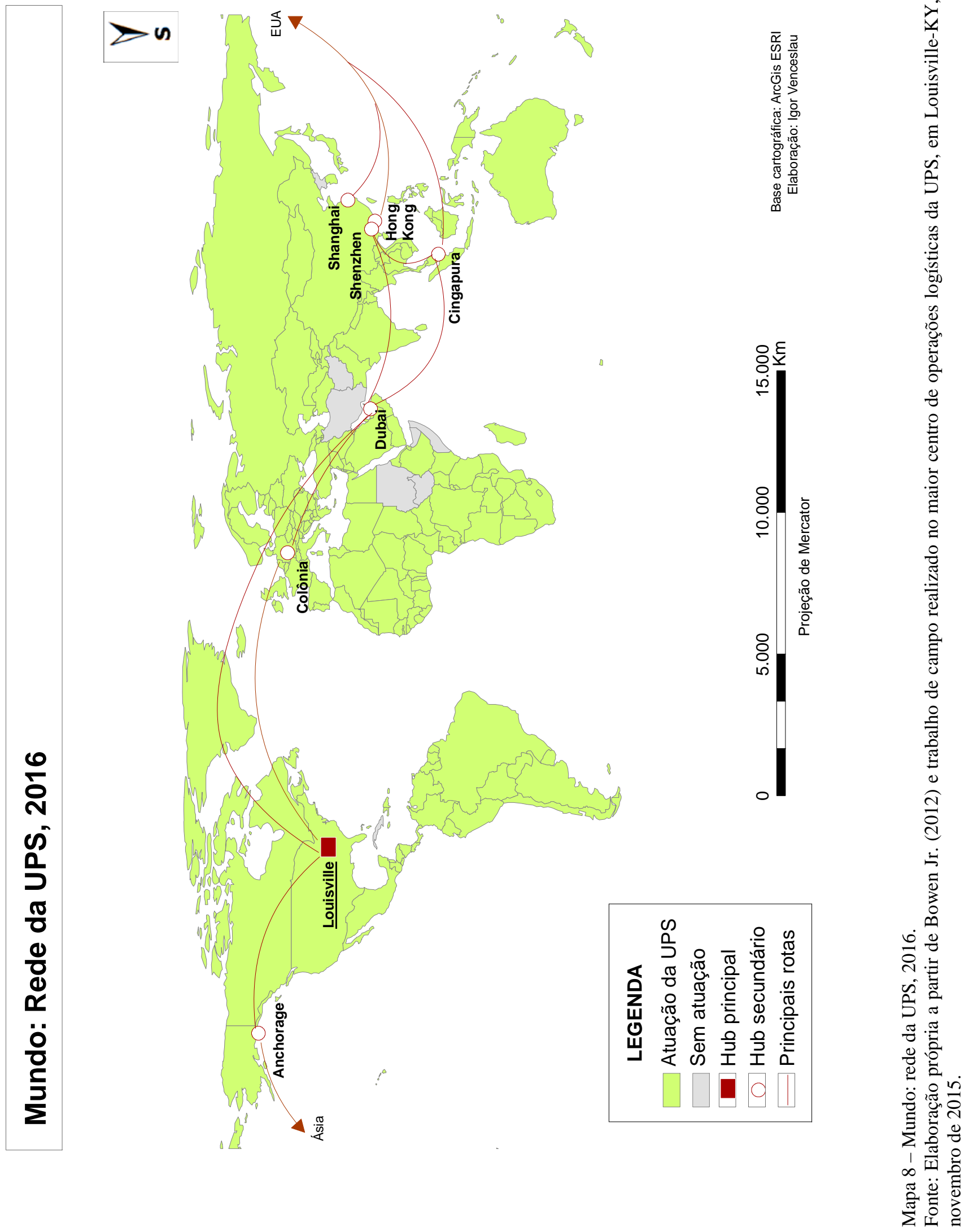




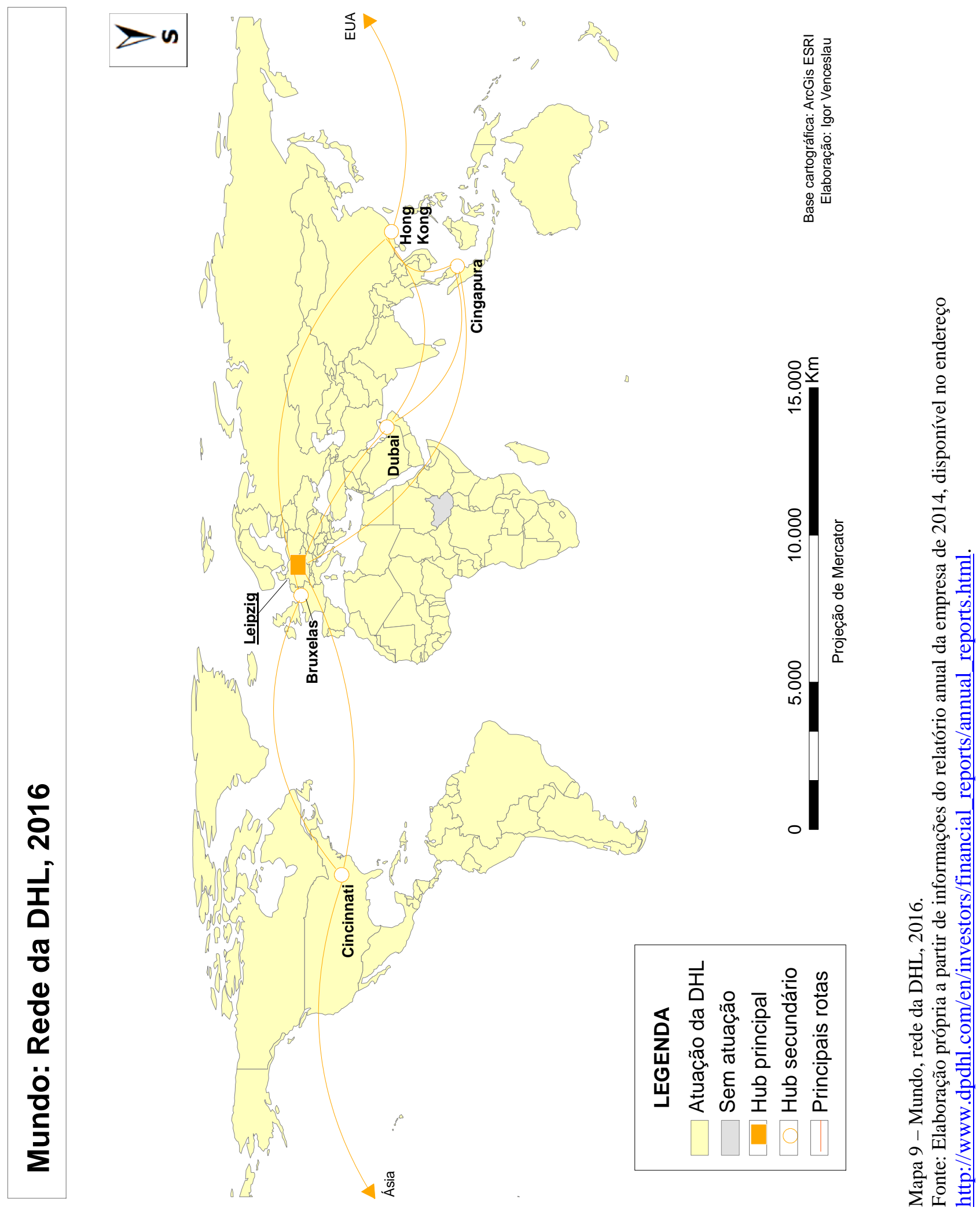


Ao contrário das empresas de transporte aéreo de passageiros, que usam bandeiras e nomes de seus países de origem nas suas marcas, as multinacionais de correio tendem a evitar essas referências nacionais e se declaram como empresas globais, pretensamente desterritorializadas. Usando siglas e acrônimos, escondem termos como federal, preferindo utilizar FedEx Corp.; united, que remete a United States, no caso da UPS; e Deutsche, que significa "alemã", escondido pelas letras DHL; todos esses são epítetos nacionais em seus nomes. O vídeo de propaganda ${ }^{95}$ dos quarenta anos da DHL, em 2011, atesta essa intenção: a empresa pergunta “A DHL é Americana ou Australiana?" (note-se que ela não inclui Alemanha ou Europa na pergunta); a resposta vem em seguida: "Nem uma, nem outra. Ela é localizada internacionalmente e operada globalmente. [...] Queremos ser a empresa de logística para o mundo"96. Já a FedEx utiliza o slogan "the world on time"97, sugerindo não apenas uma estratégia de entrega just in time, mas também que sua presença está em todos os lugares. Ainda que se admita que essas empresas sejam estruturadas em rede ${ }^{98}$, conforme apontado por Dicken ([1986] 2011), ressaltamos que elas são extremamente nacionais em suas decisões e operações, elegendo um ponto nodal em seus países-sede como encruzilhada dos fluxos globais. Desta maneira, as empresas multinacionais de correio elaboram, a seu favor, aquilo que M. Santos ([1996] 2012b) chamou de "psicosfera" - elas criam um sentido de mundo globalizado onde elas mesmas são os agentes privilegiados na circulação de objetos postais, produzindo a sensação de que os territórios e as fronteiras, bem como as empresas públicas nacionais, ou desapareceram ou não possuem mais nenhuma importância.

Para conquistar os mercados estrangeiros, as multinacionais têm se valido de uma série de estratégias, a exemplo da compra de outras empresas no país destino, como apontado por Huertas (2013) para o caso da aquisição da transportadora Rapidão Cometa pela FedEx no Brasil, ampliando a atuação no país. Outra estratégia recorrente tem sido a tradução dos slogans utilizados nas marcas das empresas e apresentados em veículos de entrega, envelopes, propagandas, website, etc. A UPS, por exemplo, traduz o seu slogan "worldwide service” na língua de muitos países onde ela opera, como nas versões em francês, "services mondiaux", e português, "serviços mundiais", passando a camuflar a sua origem estrangeira (Fotografias 5, 6 e 7). Assim, essas empresas criam uma psicosfera a favor de suas marcas, cuja repetição das

\footnotetext{
${ }^{95} \mathrm{O}$ vídeo pode ser acessado no endereço https://www.youtube.com/watch?v=T0ndhMaDWvM.

${ }^{96}$ No original em inglês, "Is DHL American or Australian? It is neither. It is based internationally and globally operated. [...] We want to be the logistics company for the world".

${ }^{97}$ A expressão pode ser traduzida para "o mundo pontual".

${ }^{98}$ Network-based logistics providers, nas palavras de Dicken ([1986] 2011).
} 
imagens na paisagem das cidades ao redor do mundo contribui para a sua aceitação como uma firma "local", naturalizando sua presença.
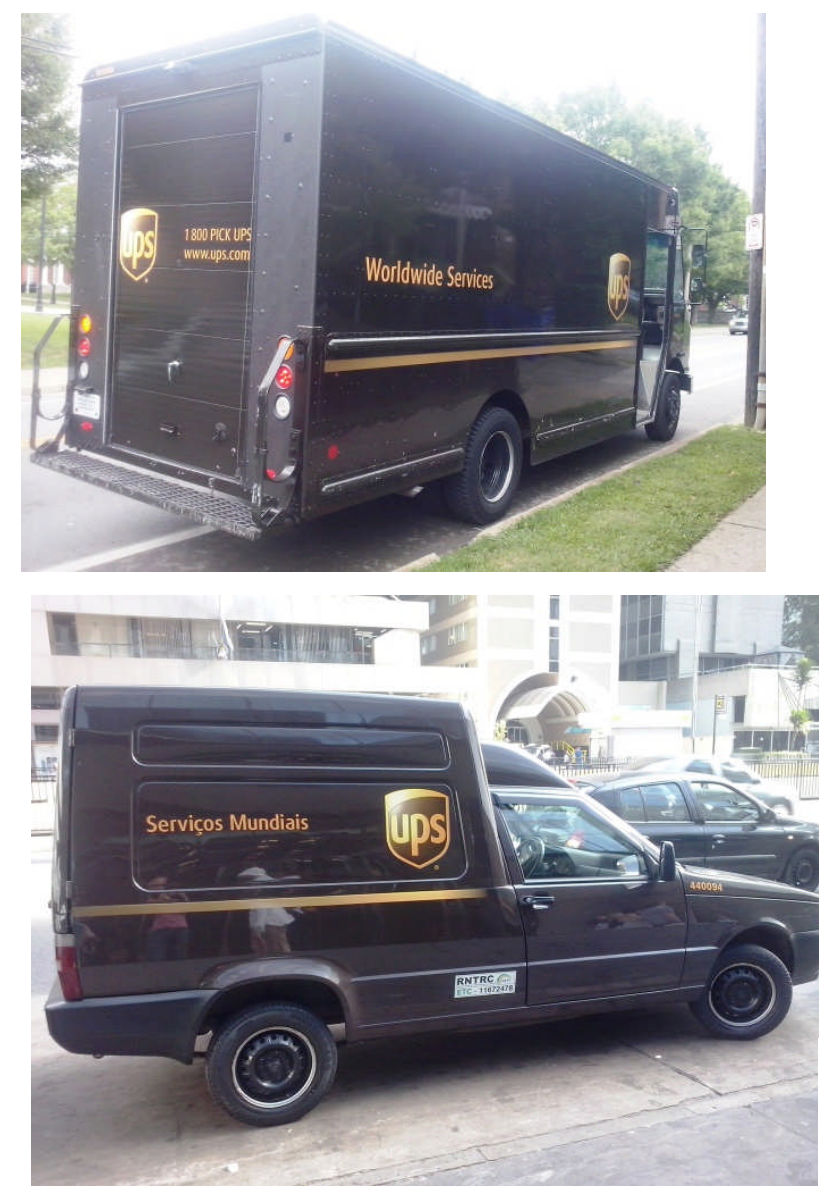

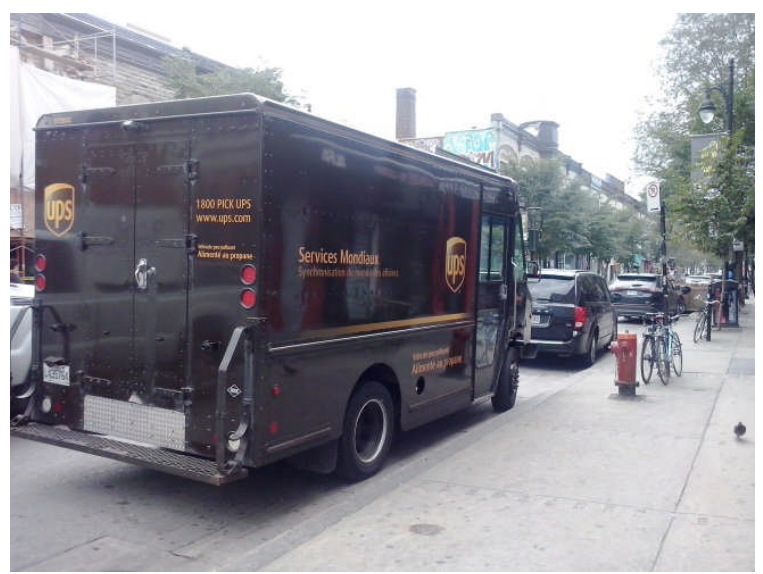

Fotografia 5 - Veículo de entrega da empresa UPS em logradouro da cidade de Lexington, Kentucky, EUA, com o slogan "worldwide services".Fonte: Trabalho de campo realizado em agosto de 2015. Foto: Igor Venceslau

Fotografia 6 - Veículo de entrega da empresa UPS em logradouro da cidade de Montréal, Québec, Canadá, com o slogan "services mondiaux". Fonte: Trabalho de campo realizado em outubro de 2015. Foto: Igor Venceslau

Fotografia 7 - Veículo de entrega da empresa UPS na Avenida Paulista em São Paulo-SP, Brasil, com o slogan "serviços mundiais". Fonte: Trabalho de campo realizado em junho de 2015. Foto: Igor Venceslau

A cooperação entre as multinacionais e empresas públicas pode ser constatada nas escalas regional e local. Em muitos casos quando a empresa não dispõe de entrega para determinados destinos, utiliza-se da prática da "re-postagem", ou seja, posta novamente o objeto, desta vez via correio público, para que o objeto possa chegar ao destino; para o cliente das multinacionais, a operação aparece como sendo totalmente efetuada por elas. Outra situação de cooperação ocorre nos EUA, onde a USPS, não dispondo de frota suficiente de aeronaves para realizar o transporte de carga dentro do país, utiliza os aviões da FedEx para realizar o transporte na escala nacional ${ }^{99}$. Em contrapartida, a FedEx utiliza a rede de entrega

\footnotetext{
${ }^{99}$ Por vários anos seguidos, a FedEx ocupa o primeiro lugar isolado no ranking das fornecedoras da USPS. Somente no ano fiscal de 2015, mais de 1,3 bilhão de dólares foi pago pela empresa pública à multinacional pelo transporte de carga postal, segundo números divulgados pela Husch Blackwell. Para o relatório completo,
} 
da empresa pública para fazer suas encomendas chegarem nas pequenas cidades e áreas mais remotas.

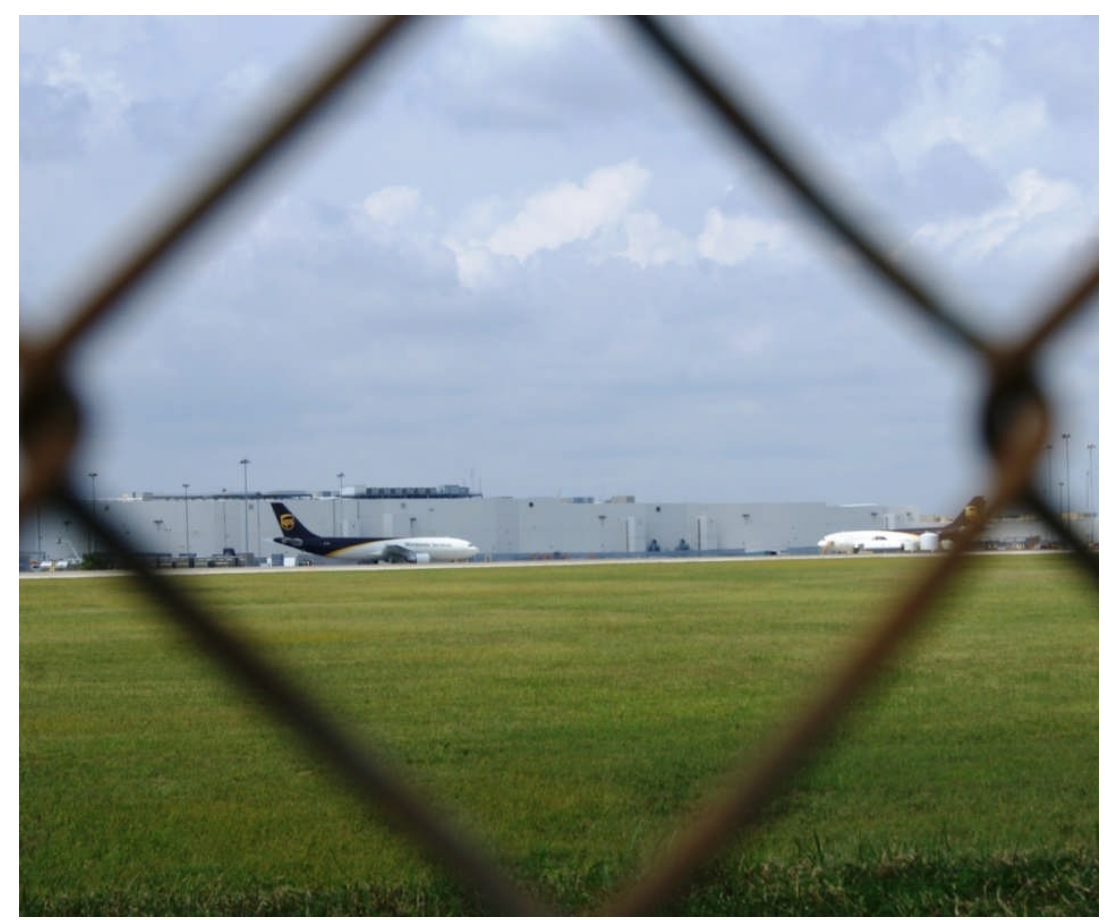

Fotografia 8 - Operações da UPS e rígido controle de acesso no centro logístico Worldport em Louisville, Kentucky, EUA.

Fonte: Trabalho de campo realizado em agosto de 2015. Foto: Igor Venceslau

Resta indagar, diante dos múltiplos "territórios postais" que se apresentam na atualidade, em que medida a logística corporativa se diferencia da milenar logística militar. A disputa das multinacionais pelo acesso e controle dos territórios por meio de suas redes não é tão dessemelhante das audaciosas estratégias militares da arte da guerra. De fato, essas empresas têm mantido suas estratégias em sigilo para garantir um diferencial competitivo entre as demais, fazendo com que suas gigantescas operações estejam escondidas dos olhares cotidianos das populações. Em seus centros logísticos, criados para garantir a livre circulação das mercadorias e informações, as pessoas são submetidas a rígido controle de acesso (Fotografia 8), o que demonstra a maneira egoísta com que essas empresas lidam com os fluxos que são de todos, embora apropriados por elas. Os recentes contratos celebrados entre a DHL e o Departamento de Defesa dos EUA para servir como operador logístico terceirizado em guerras no Oriente Médio (COWEN, 2014), valendo-se da mesma rede que distribui encomendas e correspondências em todo o mundo, revela que a cisão entre o civil e o militar,

acessar http://www.huschblackwell.com/ /media/files/businessinsights/businessinsights/2016/02/postal-servicecontracting-top150usps2015suppliers.pdf. 
separação que funda a logística empresarial, parece não fazer tanto sentido nas práticas das grandes corporações.

Apesar das tentativas de integração dos fluxos postais na escala mundial, vivemos um período de aprofundamento das desigualdades no seio da divisão internacional do trabalho. Enquanto o número de correspondências postadas per capita no ano de $2014^{100}$ foi de 18,1 na América Latina, cada pessoa postou em média 301,2 objetos do segmento mensagem nos países centrais, contra menos de 2 por habitante na África. Para o segmento de encomendas, a diferença é ainda mais acirrada: para cada mil habitantes, foram entregues 7.481 pacotes nos países centrais em 2014, o que equivale a mais de sete encomendas recebidas por pessoa. O consumo de encomendas postais nesse ano foi de apenas 115 para cada grupo de mil latinoamericanos, reduzido para 80 volumes entre os asiáticos e míseros 3 por mil habitantes na África ${ }^{101}$. Países da África, América Latina e parte da Ásia podem ser considerados como "sociedades subinformadas", para empregar um termo de Dantas (1996, p.95), sendo a subinformação um "novo nome para o subdesenvolvimento nesta nova etapa histórica da evolução capitalista". Esse fenômeno se manifesta no correio por meio das desigualdades de acesso e consumo dos serviços postais.

\subsection{O uso corporativo do território e a conformação de uma região especializada no centro dos Estados Unidos}

Os EUA são um interessante caso de estudo sobre o correio na atualidade, uma vez que foi o país de vanguarda de muitas das transformações pelas quais o correio vem passando, especialmente o surgimento e consolidação dos grandes conglomerados privados do setor postal. Também nesse país é possível verificar um caráter extremamente corporativo no uso do território pelas empresas privadas de correio, que elegem um ponto nodal para o centro de suas redes mundiais de circulação. Nesses nós foram estabelecidos os maiores centros logísticos do mundo para o tratamento de encomendas e cartas (Mapa 10), onde os fluxos nacionais e internacionais são concentrados e posteriormente a carga é reexpedida para os lugares de destino.

\footnotetext{
${ }^{100}$ Informações extraídas do site da UPU no endereço http://www.upu.int/en/resources/postal-statistics/aboutpostal-statistics.html.

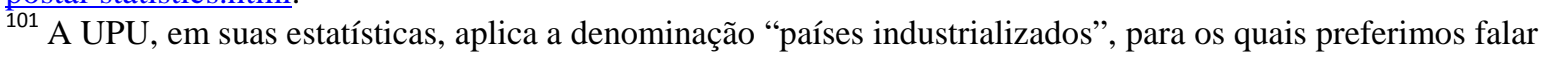
em países centrais do sistema capitalista. Nessa categoria, estão: EUA, Canadá, países da Europa Ocidental, Japão, Coréia do Sul, Austrália e Nova Zelândia.
} 


\section{EUA: Principais centros logísticos de correio privado, 2016}

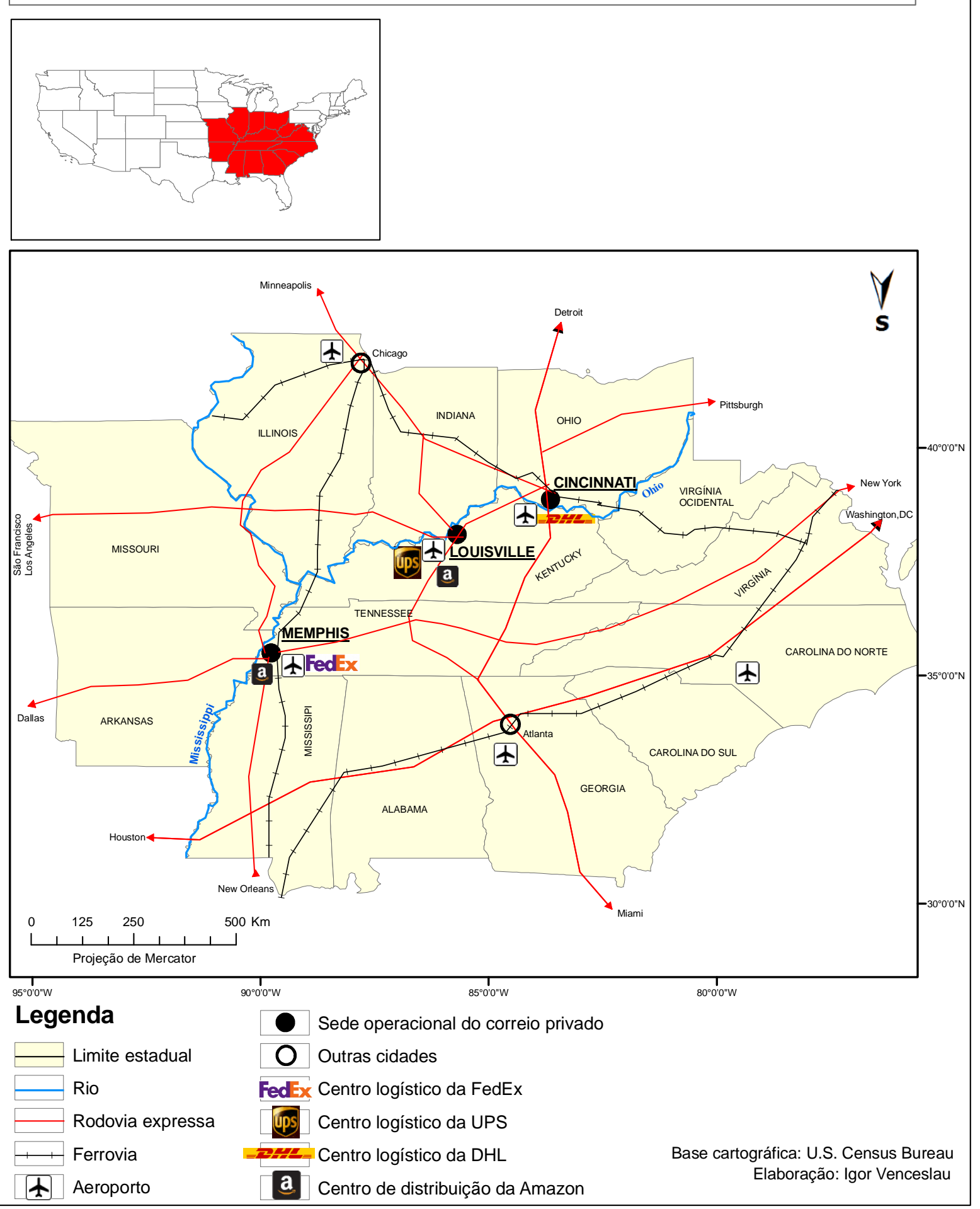

Mapa 10 - EUA: principais centros logísticos de correio privado, 2016.

Fonte: Elaboração própria a partir de informações coletadas nos websites das empresas e em trabalho de campo realizado no centro logístico da UPS em Louisville, Kentucky, em novembro de 2015. 
Desde 1973, a FedEx escolheu a cidade de Memphis, no estado do Tennessee, para estabelecer o seu maior $h u b$. No final da década de 1990 foi a vez de sua concorrente, a UPS, criar uma infraestrutura semelhante para concentrar as operações, que fica localizada na cidade de Louisville, Kentucky, estado vizinho. A alemã DHL também escolheu estabelecer um centro logístico nos EUA, que foi inaugurado em 2009 na cidade de Cincinnati, estado de Ohio, na mesma região, sendo este o segundo maior hub de sua rede, atrás apenas de suas instalações em Leipzig, na Alemanha.

A lista dos principais aeroportos do mundo vem passando por significativas alterações desde a escolha locacional dessas multinacionais, principalmente por causa da concentração de fluxos que foi gerada nesses lugares. A cidade de Memphis ocupa o segundo lugar no ranking mundial dos aeroportos de carga ${ }^{102}$, atrás apenas de Hong Kong, sendo que por muitos anos a cidade ostentou o primeiro lugar ${ }^{103}$. Em seu aeroporto foram movimentadas mais de 4 milhões de toneladas de carga, a maior parte fruto de operações da FedEx. Da mesma maneira, Louisville figura em sétimo lugar, numa lista onde além de Anchorage, Alaska, que também é usada pelas empresas como entreposto dos voos na rota EUA - Ásia, todas as demais cidades são reconhecidamente grandes metrópoles ${ }^{104}$. Em Louisville foram movimentadas 2,3 milhões de toneladas, majoritariamente pela UPS. A relevância desses lugares para o movimento de carga aponta para um uso do território que é corporativo.

Considerando que o diferencial competitivo entre as empresas do ramo de logística é o tempo de circulação das mercadorias (DICKEN, [1986] 2011), quais fatores teriam influenciado na decisão locacional desses empreendimentos? Em primeiro lugar, as empresas se beneficiam da infraestrutura de transporte disponível nas cidades de Cincinnati, Louisville e Memphis. O geógrafo Neil Brenner (1998) observou que o capital depende de infraestruturas territoriais fixas para a sua realização ${ }^{105}$, o que inclui as próprias aglomerações urbanas. Não por acaso, os pontos nodais estão localizados no cruzamento de diversas redes de transporte que atravessam o país, permitindo a intermodalidade: o modal fluvial, por meio do transporte de carga através dos rios Mississipi e Ohio, prática que está atrelada à própria

\footnotetext{
${ }^{102}$ Informações do Airport Council Internacional para o março de 2016, acessível em http://www.aci.aero/DataCentre/Airport-Statistics-Infographics.

${ }^{103}$ Conforme dados apresentados na versão atualizada de Dicken ([1986] 2011).

${ }^{104}$ Os dez maiores aeroportos do mundo em volume de carga em março de 2016 foram, na ordem: Hong Kong, Memphis, Shanghai, Anchorage, Seul (Incheon), Dubai, Louisville, Tóquio, Paris e Frankfurt.

105 "Capital necessarily depends upon relatively fixes and immobile territorial infraestructures" (BRENNER, 1998, p.461).
} 
fundação dessas cidades ${ }^{106}$; o modal ferroviário, largamente utilizado para o transporte de carga ligando os portos do Atlântico, a leste, aos do Pacífico, a oeste; o modal rodoviário, estando essas cidades no cruzamento de várias rodovias expressas (highways) que conectam o país em todas as direções; e o modal aéreo, possível graças às boas condições dos aeroportos da região. Para Mary Wiederwohl ${ }^{107}$, chefe do Louisville Forward, departamento de desenvolvimento econômico da cidade de Louisville, o que acontece hoje nessas cidades é fruto de seu passado:

As cataratas do Ohio eram impossíveis de serem transpostas pelos barcos, então ou você parava aqui [Louisville] e aportava o seu barco por aqui ou você tinha que parar aqui e passar as cataratas a pé e pegar outro barco no outro lado do rio. Logo, um povoado fundado aqui nos anos 1700, Louisville tem estado aqui oficialmente desde 1778. Então, começamos como um hub logístico no rio; somos um river port antes de nos tornarmos um Worldport. Então os bens e serviços entraram por aqui [...] Isso está mesmo no nosso DNA como cidade. E então, automaticamente desde então se desenvolveram rodovias e ferrovias. Logo temos uma rede de transporte muito robusta dentro e fora da cidade. E então nos anos 1980 veio uma empresa de serviço postal buscando uma localização central; eles automaticamente nos escolheram para o seu hub (Tradução nossa) ${ }^{108}$

Deste modo, as empresas se beneficiaram da disponibilidade de infraestrutura de transporte construída pelo Estado, estando elas em ótimas condições de uso e sem os problemas de congestionamento de tráfego típico das grandes metrópoles.

Analisando a sincronização das ações das firmas numa "economia de arquipélago" articulada em rede, Veltz (1996) considerou a decisão da FedEx e da UPS em criar um sistema hub and spoke (nó e raio) numa região de tráfego não saturado, com proximidade a autopistas e outras infraestruturas de transporte, mais eficaz para coordenar o tempo dos fluxos do que a estratégia de aglomeração (típica da indústria automobilística) em regiões já

\footnotetext{
${ }^{106}$ Durante o século XVII, os colonos franceses utilizavam os rios Mississipi e Ohio para conectar as áreas de extração de carvão e produção agrícola, a norte, com o porto de New Orleans, na Louisiana. Cidades como Louisville nasceram como entrepostos (portos fluviais) que permitiam a exportação do carvão das minas de Ohio.

${ }^{107}$ Entrevista realizada em dezembro de 2015.

108 "The falls of the Ohio were impossible to boats, so you either had to stop here [Louisville] and port your boat around or you had to stop here and go around the falls on foot and get another boat on the other side. So, a settlement was founded here in 1700s, Louisville's been here officially since 1778. So, we started out as a logistics hub on the river; we were a river port before we became a Worldport. So goods and services came through here [...] This is very much in our DNA as a city. And then, automatically from that developed interstates and rail. So we have a very robust transportation network coming in and out of the city. And then in the 1980s came a company about postal services looking for a central location; they automatically picked us for their hub".
} 
congestionadas. Para o autor, os serviços expressos são o principal exemplo da sincronização das operações numa economia mundializada ${ }^{109}$.

A localização das três cidades é privilegiada no país, possibilitando rápido acesso aos maiores mercados consumidores: todas estão a meio caminho entre o Golfo do México, a sul, e os Grandes Lagos a norte, permitindo distribuir mercadorias num raio que contempla desde Miami e Atlanta a Detroit e Chicago. Sua localização está a meio caminho entre a costa leste, onde está a megalópole Boston-New York-Filadélfia-Baltimore-Washington, e oeste, chegando às cidades de Los Angeles e San Francisco. Essa constatação foi feita também por Bowen Jr. (2012), ressaltando a importância que têm para esse tipo de atividade as cidades localizadas a meio caminho entre importantes zonas geradoras de tráfego. Conforme justificado por Eric Dunnigan ${ }^{110}$, vice-secretário de desenvolvimento econômico do estado do Kentucky, a localização é a principal causa de atração dessas empresas para esses lugares:

O que a localização significa? Significa acesso ao mercado [...] Você sabe, o mais importante é a localização geográfica do Kentucky, somos abençoados com uma ótima localização geográfica. Estamos exatamente no meio dos Estados Unidos, numa distância de um dia de viagem de $2 / 3$ da população dos EUA, ou mais importante em um dia de viagem de $2 / 3$ da riqueza dos EUA, onde se localizam as fábricas e os processos de decisão (Tradução nossa $)^{111}$

Além dos atributos locacionais, as empresas contaram também com incentivos fiscais por parte do Estado. Somente no momento de instalação de seu hub em Cincinnati, a DHL recebeu mais de US\$ 1,5 milhão em incentivos fiscais do governo do Kentucky ${ }^{112}$, onde está localizado o aeroporto. Além dos incentivos, o Estado participa ativamente em parceria com essas empresas na execução de programas de treinamento de mão-de-obra, por meio da cobertura de parte das despesas dos cursos ou assumindo totalmente essa função através das universidades e escolas públicas.

Além desses fatores, essa região dos vales dos rios Tennessee, Ohio e Mississipi é historicamente uma das que apresentam menor desenvolvimento econômico dos EUA. Também por sua localização, longe dos centros urbanos litorâneos e atravessada pelos

\footnotetext{
109 "L'exemple le plus spectaculaire de cette montée des critères de services et de délais est la progression explosive de la messagerie express" (VELTZ, 1996, p.202).

${ }^{110}$ Entrevista realizada em setembro de 2015.

111 "What does location mean? It means access to market [...] You know, the more geographical location of Kentucky, we are blessed with a great geographical location. We're right in the middle of the United State, within a day's drive of 2/3 of the U.S. population, or importantly within a day's drive of 2/3 of the U.S. wealth, where are factories and the decision processes"

${ }^{112}$ Informações coletadas em trabalho de campo no Kentucky Cabinet for Economic Development, em FrankfortKY, EUA, em setembro de 2015. As negociações e incentivos foram realizados por meio do órgão governamental denominado Kentucky Economic Development Finance Authority.
} 
grandes belts agrícolas, o centro do país era desfavorável para atividades econômicas mais robustas ligadas ao setor de comércio e serviços. Esse fator fez com que a região tivesse disponibilidade de mão-de-obra barata, já que as empresas não precisam competir por trabalhadores com outros empreendimentos de mesmo porte. Além dos baixos salários pagos aos trabalhadores, a atividade sindical é historicamente irrelevante nessa região, outro fator que contribui na escolha locacional dessas empresas. Ademais, esses empregos em logística são, em geral, mal remunerados, exigem alta produtividade por parte do trabalhador, são realizados em todos os horários, principalmente o noturno, além de utilizarem muita mão-deobra de meio turno (part-time job) e estudantes estagiários. E como as máquinas de triagem não param, e também não param de chegar e sair as aeronaves e os caminhões, os trabalhadores são forçados a trabalhar em ritmos semelhantes. Para uma ex-gerente da $\mathrm{UPS}^{113}$, essas empresas atribuem metas rígidas para aumentar a produtividade do trabalho:

É um ritmo muito rápido. Os pacotes têm que se mover, mas a pressão real é sobre a produtividade. Há muitos pacotes para serem triados por hora [...] eles têm uma meta de triagem para desembarque e embarque de pacotes por hora, e nós queríamos este certo nível de produtividade [...] E como a tecnologia muda, a meta de produtividade aumenta, todos os anos (Tradução nossa $)^{114}$

Para o American Postal Workers Union, sindicato que reúne os trabalhadores da empresa pública de correio nos EUA, as preocupações mais relevantes atualmente são a privatização e os serviços privados, bem como a competição entre os setores público e privado. De acordo com Clint Burelson ${ }^{115}$, diretor executivo da instituição, outro problema é a constante redução no número de trabalhadores por parte dessas empresas, piorando ainda mais as condições de trabalho para os que ficam:

Não há quantidade suficiente de trabalhadores como deveria haver. Elas [empresas] deveriam contratar mais, mas estão tentando cortar [número de trabalhadores] agora. É muito estressante [...] Sabe, pessoas estão enlouquecendo tentando fazer cinco trabalhos de vez. É isso que é [o trabalho nesses locais] (Tradução nossa) ${ }^{116}$

\footnotetext{
${ }^{113}$ Entrevista realizada em novembro de 2015. Por solicitação da entrevistada, sua identidade foi protegida.

114 "It's very fast pace. The packages have to move, but the real pressure is to be productive. There's a lot of packages to hit a sort of number per hour [...] they have a sorting goal unloading and loading packages per hour, and we wanted to keep this overall certain level of productivity [...] And as technology changes, the productive goals get higher, every year"

${ }^{115}$ Entrevista realizada na sede do sindicato em Washington, D.C., em dezembro de 2015.

116 "There is not as much workers as it should be. They [companies] should hire more, but they are trying to cut down [numbers of workers] now. It's very stressful [...] you know, people are going crazy trying to do five jobs at once. That's what it is"
} 
Esses mesmo fatores têm contribuído para que a região assuma um protagonismo econômico na atividade industrial. A tendência recente da indústria automobilística tem sido fechar suas fábricas no norte, principalmente em cidades como Detroit e Pittsbugh, pioneiras no ramo, e abrirem novas unidades no centro e no sul do país. Com mais de 11 mil trabalhadores em tempo integral, a Toyota já é o terceiro maior empregador privado do Kentucky, seguida da Ford com quase 9 mil funcionários no estado ${ }^{117}$. No entanto, corroborando com o peso das multinacionais de correio na região, a UPS se mantém como o maior empregador privado do Kentucky, contando com aproximadamente 13 mil empregados de tempo integral.

De acordo com Santos ([1996] 2012, p.247), “os lugares se distinguiriam pela diferente capacidade de oferecer rentabilidade aos investimentos", em virtude de suas condições técnicas e organizacionais. Esse uso das virtualidades oferecidas pelos lugares estaria atrelado a uma maior ou menor produtividade possível aos agentes econômicos, estritamente relacionadas aos atributos do espaço. A produtividade espacial permitida pela localização nessas cidades é um diferencial competitivo para as empresas, por isso mesmo elas realizam enormes investimentos em capital fixo. Aplicando o coeficiente de Gini para analisar a localização de armazéns em regiões metropolitanas dos EUA, Cidell (2010) concluiu que há uma mudança nos últimos vinte anos em direção à concentração dos serviços de frete nos vales do Ohio e Missouri, por causa das excelentes condições de transporte. Somente a UPS investiu inicialmente 2,2 bilhões de dólares na construção do centro logístico de Louisville.

A importância que possuem essas empresas nos lugares onde atuam, somado ao fato de que as três maiores multinacionais de correio competem entre si a partir de centros logísticos instalados na mesma região, aponta para uma especialização regional no Vale do Ohio-Mississipi. Seria possível afirmar que a partir da decisão da DHL de criar nessa região seu maior ponto de conexão fora da Alemanha, o Vale do Ohio-Mississipi consolidou uma de suas formas de inserção na divisão territorial do trabalho, interna ao país, e na divisão internacional do trabalho - a especialização em serviços logísticos, aí incluídos principalmente os serviços postais oferecidos por empresas privadas. Essa mesma especialização parece estar ocorrendo também em Dubai, como aponta Cowen (2014), e Hong Kong.

\footnotetext{
${ }^{117}$ De acordo com dados do Kentucky Cabinet for Economic Development para o ano de 2015. Na lista dos dez maiores empregadores privados do estado aparecem, na ordem: UPS, Humana, Toyota, Ford, Amazon, General Electric, FMR LLC, Xerox, Citigroup e Berkshire Hathaway.
} 
O uso corporativo do território por essas empresas é revelado também pela apropriação exclusiva que elas fazem das infraestruturas de transporte. Em Louisville, o centro logístico da UPS ocupa $80 \%$ do aeroporto público, numa área de meio milhão de metros quadrados, enquanto somente os $20 \%$ restantes ficam para o terminal de passageiros (Figura 8). Ratificamos as inquietações de Cowen (2004) a esse respeito, ao questionar as consequências da cidade ser feita à imagem dos fluxos eficientes de carga e o urbano ser governado em favor das trocas econômicas ${ }^{118}$. Interessante notar que apesar de ser um dos maiores terminais de carga do mundo, o aeroporto de Louisville tem poucos voos de passageiros, sendo em muitos casos mais rápido um pacote chegar a seu destino do que uma pessoa, partindo desse terminal.

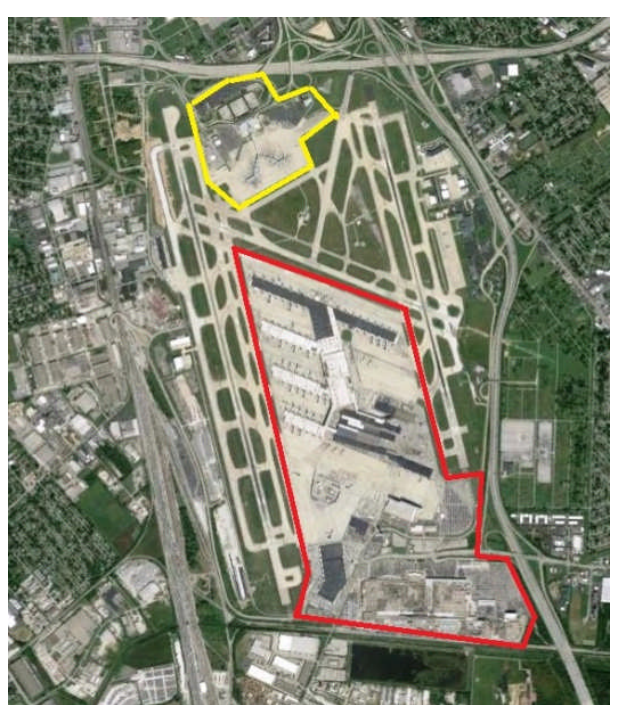

Figura 8 - Imagem de satélite do aeroporto de Louisville-KY, EUA. Em amarelo, a área do terminal de passageiros; e a área ocupada pela empresa UPS em vermelho. Fonte: Elaborado a partir de trabalho de campo realizado no centro logístico da UPS em novembro de 2015. Imagem de satélite: Google Earth.

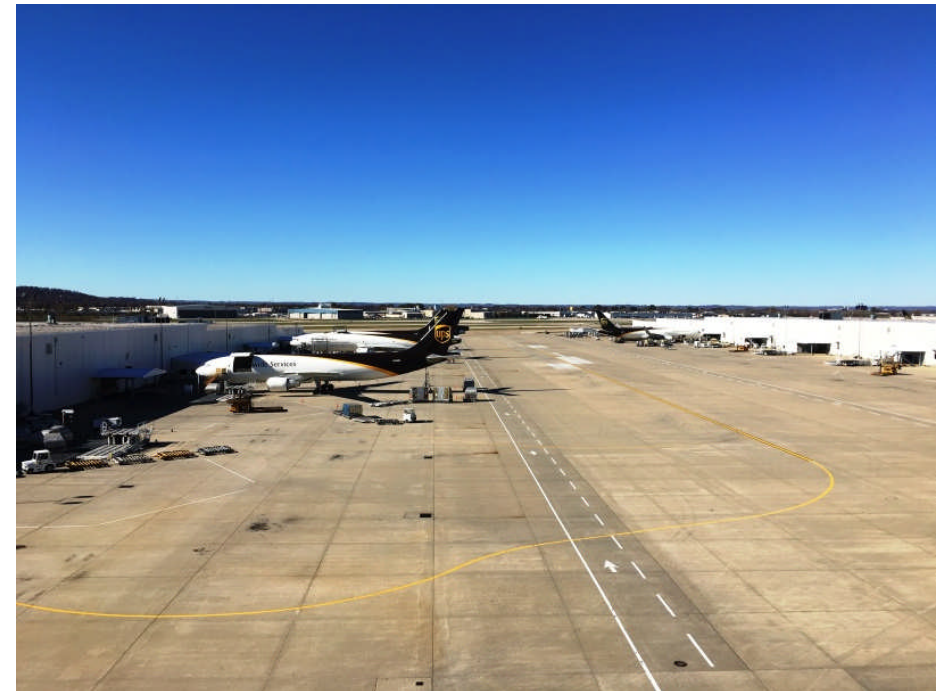

Fotografia 9 - Parte da área externa do centro logístico Worldport da empresa UPS em Louisville, Kentucky, EUA. Fonte: Trabalho de campo realizado no centro logístico da UPS em novembro de 2015. Foto: Susan Roberts.

A operação da UPS é realizada no centro logístico denominado Worldport, em Louisville (Fotografias 9 e 10). Por dia, são processados nesse empreendimento cerca de dois milhões de objetos ${ }^{119}$, trazidos e levados por 150 aeronaves $^{120}$ de todos os continentes, que

\footnotetext{
118 "What does it mean for the city to be made the image of efficient cargo flows? What does it mean for the urban to be designed and governed in the service of efficient economic exchange?" (COWEN, 2014, p.167)

${ }^{119}$ Embora a capacidade instalada desse centro logístico seja muito superior: o Worldport está preparado para processar 416 mil objetos postais por hora, ou seja, em torno de dez milhões de objetos por dia, segundo informações coletadas em trabalho de campo realizado no centro logístico da UPS em novembro de 2015.

${ }^{120}$ De um total de 1900 voos operados diariamente pela UPS. Informação coleta em Trabalho de campo realizado em Louisville-KY, EUA, em novembro de 2015.
} 
pousam diariamente nos setenta terminais de pouso simultâneo. O centro funciona ininterruptamente de dia e de noite, onde são triados desde envelopes até cargas muito urgentes, como caixas contendo lagostas vivas que devem ser entregues no Texas ou na costa oeste em boas condições para a alimentação.

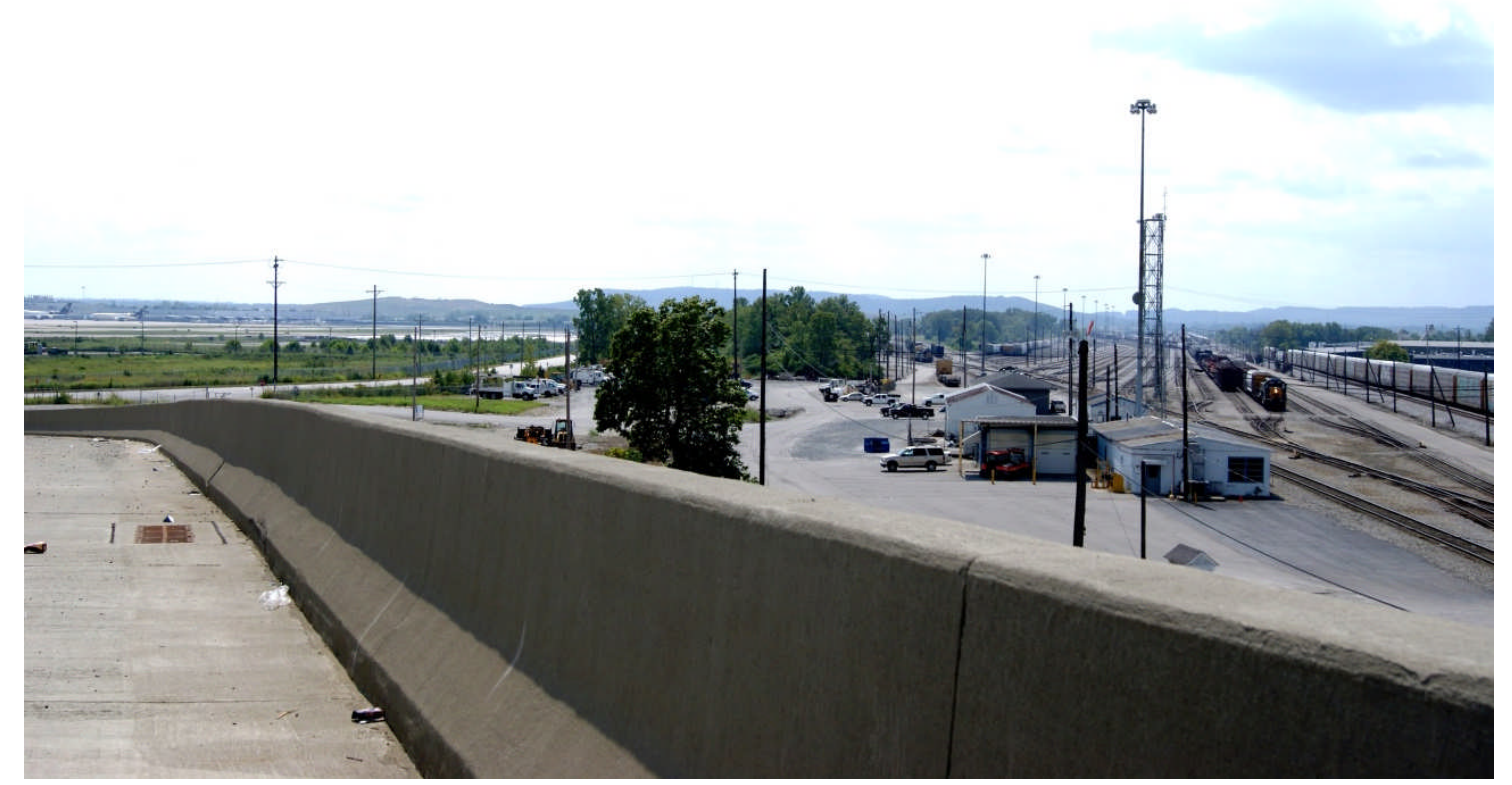

Fotografia 10 - Área ao entorno do centro logístico Worldport da UPS em Louisville-KY, EUA. A paisagem contempla a intermodalidade dos transportes na região, com a rodovia (em primeiro plano), a ferrovia (no fundo, à direita), o rio Ohio (no fundo, ao centro) e a pista de pouso do aeroporto (no fundo, à esquerda).

Fonte: Trabalho de campo realizado em Louisville-KY, EUA, em novembro de 2015.

Foto: Igor Venceslau

Empreendimentos como o Worldport são disputados pelas cidades, pois eles atraem inúmeros outros investimentos. Estima-se que cerca de 140 empresas se instalaram na Região Metropolitana de Louisville somente a partir da criação do $h u b$ da UPS $^{121}$, sendo a maioria dessas empresas intimamente dependes dos serviços de logística da multinacional. A Amazon, empresa estadunidense de e-commerce, construiu dois centros de distribuição ao lado das instalações de seus maiores operadores logísticos: um em Memphis, junto à FedEx, e outro em Louisville, próximo à UPS. Nesses locais, a Amazon emprega milhares de pessoas e já é o quinto maior empregador privado do Kentucky, com mais de 7 mil empregados ${ }^{122}$.

\footnotetext{
121 Informação coletada em trabalho de campo realizado em dezembro de 2015 no Louisville Forward, departamento de desenvolvimento econômico da cidade de Louisville-KY, EUA.

${ }^{122}$ Apesar desses investimentos, a Amazon tem financiado experimentos de novas modalidades de entrega, inicialmente em parceria com a empresa estadunidense Uber e mais recentemente por meio de um serviço próprio de entrega intermediado por aplicativo de celular, denominado Amazon Flex. O serviço já está
} 
A localização dos centros logísticos das multinacionais tem impulsionado uma espécie de "guerra de lugares" na região. Como todas as empresas localizaram suas instalações em cidades que estão no limite com outros estados, muitas localidades do outro lado da divisa têm se aproveitado para oferecer incentivos e também atrair investimentos. O caso da DHL é o mais emblemático desse tipo: apesar da empresa anunciar que opera em Cincinnati ${ }^{123}$ o aeroporto daquela cidade está localizado, na verdade, no estado do Kentucky, apenas do outro lado do rio Ohio. Na prática, todos os impostos gerados pela DHL são arrecadados pelo Kentucky, que também abriga a UPS, enquanto o estado de Ohio e a cidade de Cincinnati assumem os "custos" de ser o local de moradia da maioria dos trabalhares.

As corporações projetam no território as suas intencionalidades, e dele retiram as possibilidades de realização de seus objetivos. Ao apropriarem-se dos fixos, principalmente da infraestrutura pública de transporte, assumem seu controle sobre os fluxos, que além dos objetos postais são também fluxos de informação, de mercadorias, de investimentos e de trabalhadores. A realidade contemporânea dos EUA, de livre concorrência entre uma empresa pública e grandes empresas privadas, não aparenta ser o melhor modelo a ser seguido pelos demais países, já que as empresas privadas, ao realizar um uso corporativo do território, controlam os nichos mais lucrativos do mercado e do território, deixando para a empresa pública a responsabilidade de assumir os serviços justamente onde a atividade não é rentável, drenando os crescentes lucros do setor para a iniciativa privada e onerando o funcionamento dos serviços públicos.

disponível nas principais regiões metropolitanas dos EUA, mas tem gerado conflitos entre a empresa de $e$ commerce e a FedEx e UPS por conta de seus contratos de entrega.

${ }^{123}$ Cincinnati é utilizada de maneira simbólica pela empresa DHL inclusive por ser historicamente local privilegiado da imigração alemã nos EUA. 
A LOGÍSTICA DOS CORREIOS NO BRASIL: RACIONALIDADE, VELOCIDADE E FLUIDEZ TERRITORIAL 
De madrugada, você deveria tomar em seus braços, em seus frágeis braços, as meditações de um povo, transportá-las por entre mil ciladas, como um tesouro escondido sob o manto Antoine de Saint-Exupéry, Correio Sul ${ }^{124}$

Para compreender a logística empregada pelos Correios, faz-se necessário ter em consideração tanto o papel do correio na formação socioespacial brasileira (Capítulo 1), principalmente sua relevância para a integração territorial, quanto as transformações que vêm ocorrendo na escala do mundo e seus impactos sobre o serviço postal (Capítulo 2). Desta maneira, poderão ser encontrados na logística dos Correios os elementos velhos, heranças de tempos pretéritos que ainda são utilizadas, em coexistência com os elementos novos provenientes das mudanças no conteúdo técnico e normativo do território. Também poderá ser verificada a convivência, complementar e contraditória, entre os elementos externos, vetores da globalização, e aqueles internos ao país, que marcam a sua especificidade no mundo.

O volume de objetos movimentados pelos Correios demonstra a relevância atual do serviço postal para o país. No Brasil, foram distribuídos 8,3 bilhões de objetos postais no ano de $2015^{125}$, o que equivale a cerca de $2,5 \%$ do total mundial ${ }^{126}$. Diariamente, os Correios têm que executar estratégias logísticas que garantam com que mais de 33 milhões de cartas, encomendas, telegramas, etc., com diferentes horários estabelecidos para a entrega, cheguem a todos os 5570 municípios brasileiros. É assim que "fluxos de toda ordem tornam-se mais espessos, ampliando as necessidades de circulação e exigindo técnicas cada vez mais eficazes" (DIAS, 2005, p.12). Além da quantidade de objetos e da variedade de destinos, as desigualdades do próprio território - aí incluídas a desigual disposição da infraestrutura de transporte e as diferentes condições de fluidez territorial - contribuem para aumentar a complexidade dessa logística em escala nacional. Nessa primeira aproximação, a logística postal pode ser entendida como um conjunto de estratégias que assegura maior grau de racionalidade às ações dos Correios, bem como o aumento da velocidade dos fluxos postais.

\footnotetext{
${ }^{124}$ Saint-Exupéry, [1929] 1966, p.13.

125 Segundo dados dos Correios, disponíveis em http://correios.com.br/sobre-correios/a-empresa/quemsomos/principais-numeros.

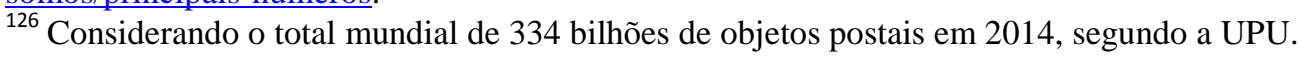


Nigel Thrift (1996) já havia notado que a variável velocidade era determinante para o serviço postal. Observando o correio inglês do século XIX, o autor comenta que serviços eficientes e rápidos permitiram a consolidação de redes de comunicação que substituíram a comunicação face-a-face, graças às inovações nos sistemas de transporte e de distribuição de energia.

No meio técnico-científico-informacional, o espaço passou a ser constituído de acréscimos crescentes de racionalidade, fazendo com que as ações se tornassem carregadas de maior grau de intencionalidade e, do mesmo modo, os objetos passassem a cumprir estritamente as funções para as quais foram elaborados (SANTOS, [1996] 2012b). Com isso, torna-se possível a padronização de processos produtivos em todo o planeta, bem como a uniformização, sempre parcial, dos gostos e dos padrões de consumo.

$\mathrm{Na}$ contemporaneidade, os fluxos materiais e imateriais conhecem um vertiginoso aumento de sua velocidade, graças aos progressos técnicos das últimas décadas. A velocidade é, ao mesmo tempo, um dado técnico e político, pois varia conforme os tipos de objetos - uma carta simples e uma encomenda expressa não circulam na mesma velocidade - e conforme os agentes que dela se apropriam (SANTOS, [1994] 2008b). As pessoas, os objetos, o capital, as mercadorias, etc. se diferenciam, inclusive, em função da velocidade com que circulam, o que se converte também num instrumento de poder. No capitalismo, a velocidade com que circulam os objetos reflete a velocidade da reprodução do capital, daí o imperativo de aceleração de todos os fluxos. E como a competitividade se tornou uma palavra de ordem no capitalismo atual, a máxima de Sun Tzu (2015, p.54) de que "a velocidade é a essência da guerra" continua vigente.

No bojo do processo de globalização, que por sua vez acarreta a mundialização do espaço geográfico, temos a aceleração de todas as formas de circulação como dado essencial (SANTOS, 1994). Para Harvey ([1989] 2011, p.219), "a história do capitalismo tem se caracterizado pela aceleração do ritmo da vida, ao mesmo tempo em que venceu as barreiras espaciais em tal grau que por vezes o mundo parece encolher sobre nós". Esta aceleração contemporânea muda decisivamente a hierarquia dos lugares, bem como a ação dos atores, sobretudo o Estado e as grandes empresas.

Assim, por suas condições técnicas e políticas, traduzidas em acréscimos de racionalidade ao espaço e nas diferentes velocidades dos fluxos, algumas porções do território são dotadas de maiores ou menores condições de fluidez. Para Santos ([1996] 2012, p.292),

É somente neste fim de século, com as novas técnicas de transmissão e coleta de informações que estamos propriamente autorizados a falar de 
fluidez do território em sentido amplo. É também agora que, por esse motivo, a noção de racionalidade do espaço se impõe mais clara e extensivamente.

Desta maneira, a fluidez territorial, um atributo do próprio território incorporado pelas empresas, se torna condição indispensável para a maior ou menor velocidade dos fluxos, diferenciando os lugares. Ali onde o território é mais fluído, pode-se afirmar que as mercadorias circulam mais rapidamente, mas os conflitos pelo uso do território estão presentes tanto nas porções mais fluídas quanto naquelas mais viscosas, com menor fluidez.

Um território que se apresenta com diferentes condições de fluidez e velocidade dos fluxos, como no caso brasileiro, pode ser desafiador para os agentes que lidam com atividades de circulação, especialmente para aqueles que são convocados a integrar o território todo, como o correio público. No intuito de conectar esse território desigual e garantir a circulação das mercadorias de uma maneira eficiente, a logística precisa lidar com diferentes estratégias, atualizando-as sempre que necessário. Que estratégias logísticas são adotadas pelos Correios para coletar e distribuir diariamente cartas e encomendas em todos os municípios brasileiros?

\subsection{Há uma logística postal?}

Conforme discutido no capítulo anterior, a introdução da logística no correio permitiu a coordenação das etapas de coleta (postagem), tratamento (triagem), encaminhamento (transporte) e entrega de correspondências e encomendas postais, contemplando o planejamento operacional prévio, seu acompanhando e a posterior avaliação da operação em conjunto, retroalimentando a etapa de planejamento estratégico. Essa mudança aconteceu em praticamente todo o mundo durante a segunda metade do século XX, impulsionada pelas novas tecnologias de informação e comunicação e pela reestruturação que afetou as empresas de correio, em muitos casos sob influência da UPU. Como consequência, têm-se o aumento da racionalidade nas ações do correio, permitindo maior precisão e controle sobre todo o processo de circulação de objetos postais; por outro lado, há o aumento da velocidade dos fluxos - materiais e imateriais -, o que veio particularmente a se desdobrar na criação de serviços expressos, com prazos flexíveis de entrega, que no Brasil correspondem aos serviços sob a marca SEDEX, dos Correios.

Deste modo, a introdução da logística no correio foi uma mudança das mais relevantes das últimas décadas. Ainda assim, cumpre indagar se se trata da logística aplicada ao correio ou se haveria algo específico dessa logística do correio que a diferencia das demais - 
industrial, agrícola, etc. - e que, portanto, marcaria a sua especificidade ante a logística em geral. Em outras palavras: há uma logística postal? Se sim, que características a diferencia dos outros tipos de logística? Antes de responder a essa questão, faz-se necessário discutir o que se está considerando por logística.

\subsubsection{Notas conceituais sobre logística}

A palavra "logística" tem origem no grego antigo logistikós, posteriormente traduzida para o latim logisticus, que era empregada no sentido de "relativo ao cálculo", segundo o Novo Dicionário Aurélio da Língua Portuguesa (FERREIRA, 2009). A logística era, em sua concepção inicial, uma denominação dada pelos gregos à parte da aritmética e da álgebra concernente às quatro operações, passando em seguida a nomear o conjunto de sistemas de algoritmos aplicado à lógica. A logística nasce, assim, estritamente relacionada à lógica e ao cálculo racional, noção que posteriormente seria reproduzida na sua aplicação em diversos campos. Na filosofia de Bertrand Russel (1872-1970), a logística reaparece como uma disciplina sobre a dimensão lógica das matemáticas (MONIÉ, 2011).

Com o tempo, a logística foi sendo incorporada às atividades militares. Atrelada à estratégia, a logística militar se tornou um diferencial de grande monta para os exércitos que podiam melhor manejá-la. Essas ideias encontram inspiração já no pensamento do general chinês Sun Tzu (544 a.C. - 496 a.C.), para quem os planos e ações já executados deviam ser alterados, diminuindo as possibilidades de o inimigo conhecer os seus próximos passos. Em seus conselhos sobre a arte da guerra, dizia: "muda os seus métodos e altera os seus planos para que ninguém saiba o que está fazendo" (TZU, 2005, p.56). As ideias modernas de estratégia, precisão e tomada de decisão na logística são inspiradas no pensamento milenar de Sun Tzu.

A logística militar se ocupou de solucionar problemas de transporte, abastecimento e alojamento de tropas, que segundo Monié (2011) correspondiam a dimensões funcionais e territoriais da operação militar. Todo o sucesso das operações militares passou a depender da logística, que por meio de suas estratégias fazia chegar ao front de batalha desde o mais trivial até aquilo que seria o diferencial da batalha: a água, os alimentos, as vestimentas, os medicamentos, os cavalos, os utensílios e materiais para a construção de alojamentos, as armas e munições, os profissionais de saúde, os grupos de soldados - enfim, a movimentação de pessoas, animais e toda a sorte de objetos e coisas, em quantidade adequada e no momento e lugar necessário, se tornou competência da logística. 
Muitos militares se destacaram por suas estratégias logísticas. O general prussiano Carl von Clausewitz (1780-1831), apesar de não ter utilizado o termo logística, reconhecia a importância das atividades que sustentam uma guerra, devendo sua preparação receber atenção especial pelos estrategistas. No século XIX, o militar suíço Antoine-Henri Jomini (1779-1869), famoso general de Napoleão, foi o primeiro a empregar o termo para as atividades militares ${ }^{127}$, concebendo a logística como uma arte prática do movimento dos exércitos (MONIÉ, 2011). No final do século XIX e início do século XX, inclusive durante a primeira e a segunda guerras mundiais, a logística foi desenvolvida e largamente empregada pelas forças armadas dos EUA, como uma atividade de preparação e emprego de recursos humanos, materiais, instalações e serviços para fins militares.

Após a Segunda Guerra Mundial, a logística passou a ser incorporada pelas empresas europeias e estadunidenses, que inicialmente introduziram os princípios militares com o intuito de realizar o suprimento de bens e produtos na Europa destruída pelos conflitos. Nas décadas seguintes, sua adoção pelas grandes empresas de todo o mundo se tornou uma tendência, em alguns casos seguida da terceirização dos serviços logísticos para um agente especializado, o operador logístico.

A logística empresarial, como passou a ser diferenciada a versão da logística voltada a atender as necessidades das empresas, pode ser entendida como o "processo de planejar, implementar e controlar de maneira eficiente o fluxo e a armazenagem de produtos, bem como os serviços de informações associados, cobrindo desde o ponto de origem até o ponto de consumo, com o objetivo de atender aos requisitos do consumidor", segundo definição do Council of Logistics Management trazida por Novaes (2007, p.35). Portanto, a logística inclui tanto atividades prévias, relacionadas ao planejamento, quanto as atividades posteriores à execução do plano, ligadas ao controle e avaliação. Além disso, os fluxos imateriais informação - têm relevância tal quais os fluxos materiais - os produtos -, sendo indispensáveis para garantir a articulação de todas as atividades desde a origem até o destino.

A logística também é entendida como planejamento estratégico para Barat (2011, p.219), para quem “o conceito de logística já não diz respeito exclusivamente às cadeias de distribuição, mas sim a um processo estratégico de planejamento e de controle de estoques e de fluxos de materiais". Os serviços de logística teriam ganhado especial relevo na atualidade sobretudo porque permitem uma inserção mais plena das empresas no processo de

\footnotetext{
${ }^{127}$ Antoine-Henri Jomini, em sua obra Sumário da Arte da Guerra, de 1836, dividiu a arte da guerra em seis partes, que são: a política da guerra, a estratégia, a grande tática, a logística, a engenharia e a tática de detalhes.
} 
globalização, racionalizando seus estoques de armazenamento e utilizando as infraestruturas disponíveis para manter as mercadorias em constante circulação.

Para Monié (2011), a logística diz respeito, antes de tudo, ao planejamento, estratégia e gestão dos fluxos, ultrapassando a dimensão de sua realização em transporte, armazenamento e controle de entrepostos. Assim, é possível diferenciar a moderna logística empresarial das atividades de transporte do passado, pois antes a circulação não estava regida por princípios de organização sistêmica baseados em informação nem pela busca de integração das funções. Deste modo, para o autor, a logística permitiu a integração definitiva das esferas tradicionalmente segregadas da produção - distribuição - troca - consumo numa única esfera.

De acordo com Sposito (1999), assumir que a logística permite a integração entre as diferentes esferas ou momentos do circuito produtivo é também romper com a tradicional concepção dos três setores da economia - primário, secundário e terciário - se se pretende compreender a complexidade das novas configurações da empresa, uma vez que a logística, classificada como atividade do terciário, permitiria também atender aos demais setores.

A logística mantém estreita relação com o território, conforme demonstrado por Savy (1993). Para o autor, a logística será um elemento primordial para a organização do território durante todo o século XXI. De acordo com M. R. Silveira (2009), o conjunto de estratégias, planejamento, gestão e transformações tecnológicas no setor de transporte e comunicação impacta de tal maneira sobre o território que permite, como consequência, "ampliar as interações espaciais e mudar a ordem socioeconômica vigente" (SILVEIRA, M. R., 2009, p.14). Essas intervenções na maneira como o território está estruturado só são possíveis porque, além dos atributos da flexibilidade e da confiabilidade, a logística se assenta sobre a velocidade (DICKEN, [1986] 2011), promovendo, assim, conexões rápidas entre alguns pontos privilegiados.

Para Cowen (2014), logística tem que ver a o suprimento das necessidades materiais diárias das populações do planeta, e por isso mesmo é um serviço prenhe de conflitos. Desta maneira, se relaciona intimamente com políticas de securitização dos fluxos de mercadorias e se coloca como uma questão política atual. Reproduzindo o "mapa atual do Imperialismo", a logística se realiza no jogo contraditório de interesses de atores em diferentes escalas e desafiando constantemente a ordem estabelecida dos territórios nacionais.

Para Castillo (2011), a logística é um conjunto de competências, ao mesmo tempo materiais, normativas e operacionais: 
o conjunto de competências materiais (infraestruturas e equipamentos relacionados ao transporte, ao armazenamento, à distribuição, à montagem de produtos industriais, aos recintos alfandegários, etc.), normativas (contratos de concessão, regimes fiscais, leis locais de tráfego, pedágios, regulações locais para carga e descarga, etc.) e operacionais (conhecimento especializado detido por prestadores de serviços ou por operadores logísticos) que, reunidos em um subespaço, conferem fluidez e competitividade aos agentes econômicos e aos circuitos espaciais produtivos. Trata-se da versão atual da circulação corporativa (CASTILLO, 2011, p.339-340)

A logística empresarial como uma versão atualizada da circulação corporativa permite considerá-la como uma variável do atual período de globalização e uma atividade desempenhada num meio técnico-científico-informacional, diferenciando-a qualitativamente de atividades correlatas de transporte e armazenagem de outros períodos históricos. Desta maneira, a abordagem e os objetivos estabelecidos neste trabalho apresentam afinidades com o conceito de logística elaborado pelo autor.

A logística pode ser aplicada a diversos ramos de atividades produtivas, gerando tipos específicos de logística. Assim, é possível admitir as especificidades de uma logística industrial, moldada às finalidades e necessidades da indústria. Do mesmo modo, pode-se falar em logística agrícola, de petróleo, etc., conforme algumas características da atividade-fim que conferem ao serviço logístico uma peculiaridade que o distingue da logística em geral. Mas haveria também uma logística postal? Além da própria quantidade de objetos movimentada, mais de 330 bilhões por ano, o que distinguiria uma logística do correio dentre os serviços de logística em geral? Destacamos a seguir quatro atributos por meio dos quais seria possível distinguir uma logística postal: pela natureza do objeto, pelo espaço, pelo tempo e pelos agentes envolvidos. Essa logística corresponde àquela desempenhada pelos agentes públicos, já que as empresas multinacionais escapam da obrigação de oferecer um serviço postal em caráter universal.

\subsubsection{A natureza do objeto postal}

O objeto postal possui características sui generis que o distinguem dos demais tipos de objetos, o que por conseguinte permite uma distinção da logística que cuida de sua circulação (Figura 9). Por objeto postal estamos considerando definição vigente da Lei 6.538/78 do Brasil, que em seu artigo $47^{\circ}$ esclarece se tratar de "qualquer objeto de correspondência, valor 
ou encomenda encaminhado por via postal", incluindo desde as cartas até pacotes e caixas, de peso e tamanho previamente estabelecidos, sujeito a todos os tipos de prazos de entrega.

No objeto postal tal qual o conhecemos hoje podem ser reconhecidas três dimensões. A primeira dimensão diz respeito ao seu conteúdo, quer se trate de uma carta ou de outro objeto, como um sapato ou um aparelho de celular, por exemplo. Esse conteúdo ainda não é o objeto postal per se, mas aquilo que é de posse do remetente e que necessita ser enviado para outro ponto do espaço diferente do que o remente está. Nesse sentido, já se pode fazer uma diferenciação entre uma carta (conteúdo), como a Carta de Caminha, e um objeto postal, que é mais que o seu conteúdo. O conteúdo deve chegar seguro ao destino, intacto, da mesma maneira como fora confiado pelo remetente e dono do que está contido a um prestador de serviço postal; caso contrário, a firma de correio deve ser responsabilizada pelos danos causados. Além da segurança, a própria informação a respeito do que se trata esse conteúdo deve ser protegida e mantida em sigilo, impedindo qualquer outra pessoa além do remente de conhecê-lo. Nem mesmo o próprio prestador de serviço postal, e principalmente este, pode obter informação a respeito do conteúdo do objeto no ato da postagem ou violá-la em algum momento posterior, devendo zelar para manter o segredo dessa informação. Nem ainda ao destinatário se dá a conhecer qual é o conteúdo do objeto até que o receba e abra, já que a firma postal não sabe e nem pode transmitir essa informação. Essa primeira dimensão - o conteúdo, a mensagem - está relacionada com uma informação de dentro do objeto postal, uma informação no objeto. É a sua primeira dimensão informacional.

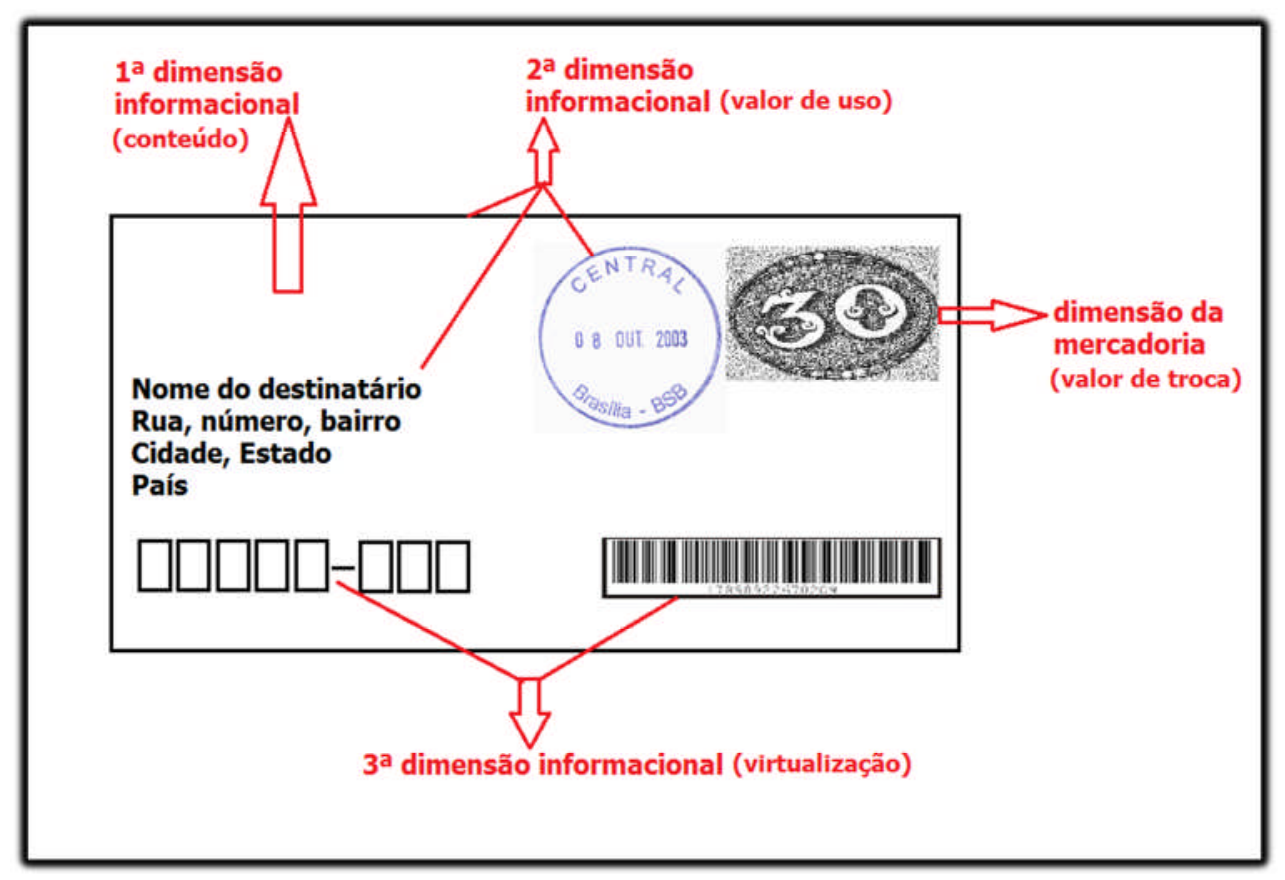

Figura 9 - Modelo de objeto postal com seus elementos principais. Fonte: Elaboração própria. 
A segunda dimensão informacional assinala o próprio surgimento do objeto postal, pois corresponde ao invólucro adicionado pelo prestador do serviço ao objeto confiado pelo remetente. Trata-se dos elementos mais básicos que em conjunto compõem o continente que resguarda tanto a integridade física quanto o segredo da informação do conteúdo. O primeiro desses elementos é o envelope que, impedindo o acesso direto ao conteúdo, deve chegar ao destino em perfeito estado, sem nenhum sinal de rasgos ou remendos. No envelope é anotado pelo remetente outro elemento - o nome e endereço do destinatário - indispensável para a entrega. Ressalte-se que o remetente pode se utilizar do anonimato, sendo facultativo a ele fornecer informações suas como nome e endereço. Nesse momento de criação do objeto postal é aposto um carimbo ao envelope, contendo indicações da data e do local de sua origem. Esses três elementos - envelope, nome e endereço do destinatário e carimbo constituem a segunda dimensão informacional e correspondem ao próprio objeto postal em sua forma mais tradicional. Ao contrário do conteúdo, trata-se de uma informação de fora do objeto, uma informação do objeto, devendo estar explícita e jamais podendo ser escondida. Essa segunda dimensão informacional metamorfoseia o conteúdo em objeto postal, escondendo-o e garantindo a sua segurança e inviolabilidade.

Mas os elementos que assinalam a metamorfose de um objeto (carta, encomenda ou qualquer outro) em objeto postal garantem apenas o seu valor de uso. Por muito tempo o correio bastou-se à utilização do envelope, endereço do destinatário e carimbo, sem pagamento pelos serviços. Com a reforma postal do século XIX, o objeto postal adquire uma dimensão de mercadoria, passando a contar com uma estampa sobre o envelope - o selo - que assinala o que Marx ([1859] 2008) denominou de valor de troca. A partir desse momento, o selo passou a ser utilizado como uma moeda que autoriza a circulação dos objetos postais por meio de seu pagamento prévio pelo remetente, com posterior obliteração feita com o carimbo para evitar a reutilização do mesmo. Com o tempo, as características do objeto como suas dimensões, peso, a distância entre as localidades de origem e destino e a velocidade com que circulava (prazos de entrega) passaram a determinar o preço pago nas remessas.

Após a revolução técnico-científica da segunda metade do século XX, o objeto postal adquire uma nova dimensão informacional, materializada no CEP e na etiqueta com código de barras, ambos adicionados ao envelope. Se o CEP racionaliza o espaço ao traduzir as suas localizações em números, a etiqueta contém informações sobre o peso, as medidas, o preço, o destino e o tipo de objeto. Duas consequências principais se desdobram dessa terceira dimensão informacional: uma técnica, com o aumento na velocidade de circulação dos objetos; e outra política, com a coordenação simultânea das ações e a vigilância sobre os 
fluxos e sobre as tarefas desempenhadas pelo trabalhador. Agora, têm-se uma informação para o objeto, como insumo indispensável à sua circulação, cuja decodificação depende de um aparato tecnológico específico. Neste momento, o objeto postal se virtualiza: sem perder a sua dimensão material, se transforma em um fluxo imaterial, uma informação, um número, cuja manifestação mais acabada é o rastreamento dos objetos, que possibilita ao remetente, ao prestador do serviço e ao destinatário localizá-lo em qualquer ponto do espaço e acompanhar todo o processo de circulação. Apesar de conter todas as outras dimensões anteriores, somente a partir de então se pode afirmar que o objeto postal se transforma num objeto informacional (SANTOS, [1996] 2012b), um objeto-informação, pois a informação é tornada a energia principal de seu funcionamento - antes, durante e depois de sua realização.

O que distingue, na prática, um objeto postal expresso e um não expresso é uma etiqueta adesiva. A etiqueta aposta ao anverso do objeto transforma o próprio objeto em informação, definindo como ele deve ser tratado a partir de então. Como os objetos, nesse período, passaram a funcionar de maneira sistêmica (BAUDRILLARD, 1973), o próprio objeto postal, a partir da informação que carrega, aciona uma série de outros objetos, assegurando maior velocidade.

Por sua natureza, podemos considerar o objeto postal como um continente criado para ocultar um conteúdo (princípio da inviolabilidade) - outro objeto, mensagem ou encomenda fazendo-o desaparecer de um lugar e reaparecer em outro (princípio do sigilo), possuindo um valor de uso e um valor de troca. Sua função primordial seria assegurar a circulação de um ser que, deixando de ser no lugar onde está, volta a ser num outro lugar ${ }^{128}$. Atualmente, o objeto postal adquire uma nova dimensão informacional, que adiciona à sua materialidade uma qualidade virtual.

Numa primeira aproximação, as etapas de coleta, tratamento, encaminhamento e entrega de objetos postais podem ser consideradas análogas àquelas da produção, distribuição, troca e consumo, apresentadas por Marx para o processo geral de produção (MARX, [1859] 2008). De fato, sob a perspectiva do correio, o procedimento de postagem realizado na etapa da coleta corresponde ao momento quando o objeto postal é produzido, pois ali ele adquire os itens que o configuram como tal. É no ato da postagem mesmo que a data constante na marcação do carimbo evidencia a produção ou nascimento do objeto postal. Do mesmo modo, poder-se-ia dizer que seu "consumo" se realiza na etapa da entrega, momento quando o envelope é aberto pelo único que possui a prerrogativa (inclusive jurídica) de fazê-lo, o

\footnotetext{
${ }^{128}$ Em língua inglesa, por exemplo, a palavra ship é utilizada tanto no sentido de "postar, postagem" quanto de "navio", pelo significado comum de "enviar" para ambas as coisas.
} 
destinatário. Violado o princípio de sigilo da correspondência, o objeto postal chega ao final de seu processo cumprindo a sua função, encerrando-se assim as obrigações por parte da empresa postal tanto com o remetente quanto com o destinatário. Por sua vez, as etapas de tratamento e encaminhamento são intermediárias, tal qual a distribuição e a troca.

Um olhar mais atento sobre o processo de produção irá revelar que essa equivalência deve ser tomada com maior cautela. Saindo do âmbito do correio e compreendendo a produção social geral, vê-se que a função desempenhada pelo serviço postal é de intermediário, seja para as mensagens, seja para as encomendas. Se se aceita que o objeto postal é "produzido" ou "consumido", deve-se fazê-lo por abstração, pois ele é um elo que aproxima o remente e o destinatário, para os quais o que realmente importa é o conteúdo - a mensagem, a mercadoria - que será trocado por meio do invólucro que é o objeto postal. Portanto, no processo geral de produção, o serviço postal pode ser considerado como um momentum, uma parte de um todo maior.

\subsubsection{O espaço}

A logística desempenhada pelo correio é específica também por seu atributo espacial. Ela deve lidar com estratégias e fluxos que considerem todas as cidades, com todos os logradouros e endereços, articulando desde a escala local e regional até a nacional e mundial, por meio de serviços básicos até os mais complexos. Essa complexidade de destinos contém desde os logradouros residenciais dos domicílios até os comerciais, áreas industriais, governamentais, etc. Nesse sentido, o correio, principalmente o público, deve estar preparado para realizar entregas nas mais diferentes situações e lugares, diferente de uma logística dedicada a um tipo de cliente ou produto.

Nesse sentido, ao lidar com "o espaço de todos os homens, de todas as firmas, de todas as organizações" (SANTOS, [1994] 2008b, p.50), a logística do correio ocorre naquilo que o M. Santos denominou de espaço banal. Aqui se aplica o princípio de universalidade do serviço postal, no qual foge da competência do prestador público poder escolher alguns lugares em sua lista de destinos atendidos, como ocorre no caso de empresas transportadoras de carga ou de passageiros. Com a obrigatoriedade de atingir todos os lugares, o espaço dessa logística se confunde ao próprio território nacional. 


\subsubsection{O tempo}

Também é possível distinguir a logística do correio pelo atributo do tempo. Além de atender a todos os lugares, deve fazê-lo com constância e regularidade, diferentemente de operações dedicadas ou sazonais de outros tipos de logística. A estratégia elaborada pelo prestador de serviço postal deve dar conta de atender cada endereço singular pelo menos uma vez por dia, ou ainda mais de uma vez por dia, no caso de serviços expressos com horário determinado de entrega. Assim, a logística postal se caracteriza por ser ininterrupta.

Pela regularidade e frequência diária, essa logística se inscreve num tempo do cotidiano. Esse cotidiano comum compartido entre todas as pessoas, firmas e instituições é uma das dimensões do espaço banal (SANTOS, [1996] 2012b), desafiando o correio a atender todos os lugares ao mesmo tempo. A sincronização racional das ações da logística se depara com os desafios do tempo do cotidiano, pois a mesma aeronave, o mesmo caminhão e a mesma bolsa do carteiro transportam objetos destinados tanto às empresas privadas, que têm pressa, quanto às escolas públicas e às pessoas aposentadas. Assim, coordenam numa mesma logística a entrega de cartas, ordens de pagamento (faturas e contas de consumo), documentos, mercadorias, objetos perecíveis, medicamentos, etc. para pessoas e instituições que operam em diferentes ritmos e velocidades.

\subsubsection{Os agentes}

Por fim, argumentamos que há uma logística postal em virtude dos agentes nela envolvidos. Contemplando todos os agentes, escapa do prestador do serviço postal a competência de escolher quais deles podem ou não ser atendidos ou com os quais estabelecer contrato, se constituindo como um elo de conexão entre todos eles. Esse atributo também está presente no princípio da universalidade, cujo intuito é garantir o acesso mínimo ao serviço postal por todas as pessoas. Individualmente ou em associações coletivas, todos podem ser remetentes de objetos postais e, do mesmo modo, seus destinatários. Nesse sentido, a estratégia logística do correio se depara com a obrigatoriedade de incluir tanto as pessoas físicas quanto jurídicas, tanto o Estado e suas instituições quanto agentes corporativos e os sujeitos "comuns".

Portanto, a logística realizada pelo correio, uma logística postal, se diferencia pela natureza da mercadoria transportada, principalmente sua inviolabilidade e sigilo, pela 
obrigatoriedade do atendimento em todos os lugares e a todos os agentes, garantindo a sua universalidade, e pela sucessão ininterrupta do tempo do cotidiano.

\subsection{A complexidade técnica e a racionalização da rotina operacional dos Correios}

A logística dos Correios é uma estratégia de conexão dos 55 milhões de domicílios brasileiros $^{129}$. Na verdade, a matriz com a qual a empresa trabalha é gigantesca: sua meta é permitir a articulação de cada um dos 55 milhões com todos os outros 55 milhões de domicílios $^{130}$. Para tornar esse cálculo ainda mais complexo, a matriz de origens e destinos deve ser multiplicada pelos quatro canais diferentes de serviços postais, cada um deles exigente de tratamento operacional diferenciado. Esses quatro canais correspondem a segmentos de serviços, ou mesmo a uma tipologia atual dos serviços postais dos Correios, essencial para compreender sua logística (Quadro 7).

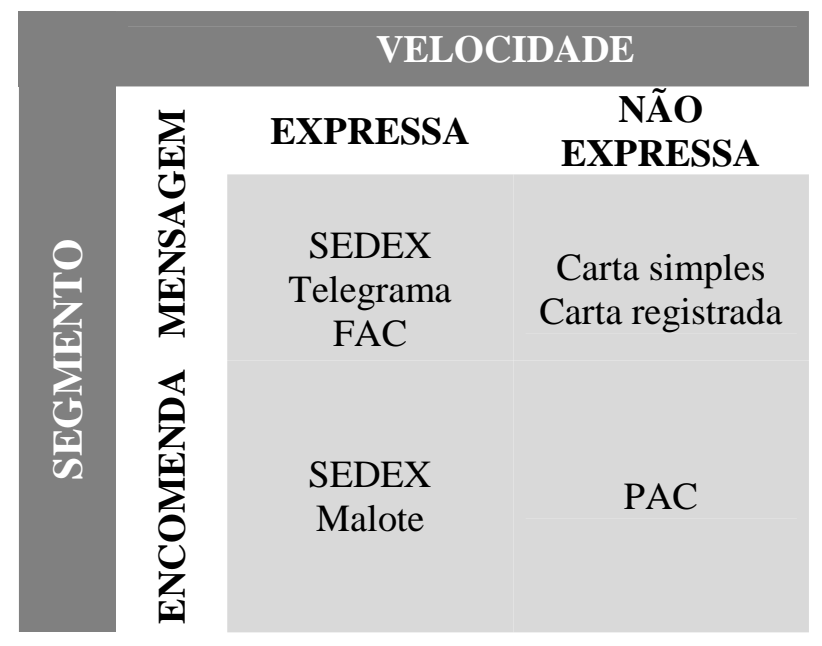

Quadro 7 - Tipologia dos serviços postais nacionais dos Correios no Brasil, 2016.

Fonte: Elaboração própria, a partir de dados da Vice-Presidência de Encomendas dos Correios.

Os serviços não expressos correspondem àqueles mais tradicionais, sem urgência na entrega. No segmento mensagem, incluem a carta simples e a carta registrada, esta última possuindo uma etiqueta com código de barras para permitir o seu rastreamento. O serviço PAC $^{131}$, encomenda não expressa criada em 2002, também faz parte desse grupo,

\footnotetext{
${ }^{129}$ Segundo informações da Vice-Presidência de Encomendas dos Correios, adquiridas em trabalho de campo realizado em Brasília-DF em março de 2016.

${ }^{130} \mathrm{O}$ que gera uma matriz extraordinária com um total de 3.035.000.000.000.000 de possibilidades reais de origem-destino diferentes.

${ }^{131}$ O serviço PAC, cuja nomenclatura é um acrônimo de "Prático, Acessível e Confiável", foi criado em substituição ao antigo serviço "Encomenda Normal” (CORREIOS, 2016).
} 
apresentando uma alternativa mais barata para o envio de pacotes. Já os serviços expressos possuem prazo determinado para a entrega, que varia de acordo com o destino da remessa. No segmento mensagem há o telegrama ${ }^{132}$, com entrega em apenas algumas horas após a postagem, e o $\mathrm{FAC}^{133}$, lançado em 1985 e utilizado para envio de ordens de pagamento (contas de consumo e faturas de catões de crédito) por pessoa jurídica a todos os tipos de destinatários. As encomendas expressas correspondem ao malote, serviço de correspondência agrupada oferecido desde a década de 1970, e utilizado principalmente por empresas; e ao Serviço de Encomenda Expressa Nacional (SEDEX). Esse último, lançado em 1982, comparece em ambos os segmentos porque pode ser utilizado tanto para o envio de envelopes com papeis e documentos quanto para pacotes com demais objetos e mercadorias, embora mantenha até hoje o nome de "serviço de encomenda". Apesar de mais caro, o volume de encomendas expressas supera as não expressas no Brasil: dos 215 milhões de encomendas entregues pelos Correios em 2015, 81 milhões delas corresponderam ao PAC, contra 134 milhões de SEDEX, sendo que cerca de 50\% dessa carga é oriunda do comércio eletrônico ${ }^{134}$.

Para Gertel (1991, p.126), “a distinção das correspondências em urgentes e não urgentes, no encaminhamento, é produto da combinação das necessidades do mercado e a capacidade de discernimento dos instrumentos postais pela empresa". Acrescentamos que essa distinção também corresponde a uma necessidade da logística em racionalizar os fluxos do correio para possibilitar uma posterior racionalização do espaço.

Conforme exposto por Raffestin (1993), circulação e comunicação correspondiam à mesma rede no passado, mas a tecnologia contemporânea terminou por dissociá-las. Pensando na logística atual dos Correios, que apesar de classificar os objetos em mensagem e encomendas os agrega numa mesma rede de entregas, e ainda refletindo sobre as funções que o correio cumpre hoje para além da comunicação postal, haveríamos ainda de considerar essa separação entre circulação e comunicação?

A partir da classificação dos objetos pelo tipo de serviço, que já ocorre no momento da postagem com a aplicação de uma etiqueta identificadora, os Correios estabelecem as próximas etapas da operação logística, que podem ser dividida nos âmbitos interno, dentro das

\footnotetext{
${ }^{132}$ O serviço de telegrama passou por uma reestruturação no ano de 2003, quando o prazo para a entrega foi reduzido para 2 horas. Essa aceleração foi possível graças à implantação de computadores conectados à Internet e aparelhos de Fax em todas as agências, além da nova tecnologia de escrita a laser, sem palavras cortadas e com acentuação. Além disso, o remetente passou a contar com os serviços de telegrama agendado, com data e hora previamente estabelecidas para a entrega (CORREIOS, 2016).

${ }^{133}$ Sigla para "Franqueamento Autorizado de Cartas".

${ }^{134}$ Segundo dados da Vice-Presidência de Encomendas dos Correios, adquiridos em trabalho de campo realizado na sede da empresa em Brasília-DF em março de 2016.
} 
dependências da empresa, e externo, fora dela. Internamente, os turnos de trabalho dos principais centros logísticos dos Correios são definidos conforme a velocidade correspondente aos objetos (expresso e não expresso) e ao destino da carga, se exportação - para tratamento dos objetos enviados para fora da região atendida - e importação - para tratamento de objetos com origem externa para entrega dentro da região atendida pela unidade operacional (Quadro 8). Tomando como exemplo o Centro de Tratamento de Encomendas (CTE) Jaguaré ${ }^{135}$, a maior unidade operacional dos Correios, localizada em São Paulo-SP, no primeiro turno de trabalho são abertas as malas com as encomendas não expressas que foram postadas no dia anterior e ficaram armazenadas durante a noite, oriundas das agências localizadas em toda a porção oeste da Região Metropolitana de São Paulo (RMSP). Durante seis horas, elas são separadas por destino e reencaminhadas pelo modal de transporte adequado até o local de entrega. No turno seguinte, as encomendas expressas, incluindo o SEDEX e todos os seus derivados - SEDEX 10, SEDEX 12, SEDEX Hoje e SEDEX Mundi - postadas nas agências da região passam pelo mesmo procedimento, com a diferença de que neste caso correspondem aos objetos postados no mesmo dia e encaminhados para o CTE após o fechamento das agências. Assim, os objetos expressos não ficam "parados" durante a noite e são encaminhados para o destino no mesmo dia da postagem, assegurando o prazo ${ }^{136}$. No turno da madrugada, os objetos dos dois tipos oriundos de todo o país para serem entregues da porção oeste da RMSP são separados e encaminhados para as unidades locais de entrega. Desta maneira, a unidade de tratamento, elo entre a agência de postagem e as unidades de entrega, funciona ininterruptamente, inclusive aos finais de semana e feriados. Toda essa racionalização das ações da empresa contribui para aumentar a produção de normas internas, levando a uma maior complexidade do trabalho nos Correios.

\begin{tabular}{|c|c|c|c|}
\hline TURNO & $\begin{array}{l}\text { HORÁRIO DE } \\
\text { FUNCIONAMENTO }\end{array}$ & $\begin{array}{l}\text { TIPO DE OBJETO } \\
\text { TRATADO }\end{array}$ & DESTINO \\
\hline TURNO 1 & 09 às $15 \mathrm{~h}$ & Não expresso & Exportação \\
\hline TURNO 2 & 15 às $23 \mathrm{~h}$ & Expresso & Exportação \\
\hline TURNO 3 & 23 às 09h & $\begin{array}{l}\text { Expresso e } \\
\text { não expresso }\end{array}$ & Importação \\
\hline
\end{tabular}

Quadro 8 - Turnos de trabalho do Centro de Tratamento de Encomendas Jaguaré, em São Paulo-SP.

Fonte: Elaborado a partir de dados coletados em trabalho de campo no CTE Jaguaré em outubro de 2014.

\footnotetext{
${ }^{135}$ Apesar do nome alusivo ao bairro paulistano do Jaguaré, a unidade está localizada no bairro vizinho da Vila Leopoldina.

${ }^{136}$ A carga expressa já sai dos caminhões diretamente para o terminal aéreo de carga em pallets aeronáuticos.
} 
O CTE Jaguaré realizada a triagem e encaminhamento de mais de 100 mil objetos postais por dia, sendo que somente no turno 2 o volume ultrapassa os 50 mil objetos expressos, boa parte deles oriundos das empresas de comércio eletrônico ${ }^{137}$. Aliado à racionalização dos turnos de trabalho, o emprego da máquina de triagem garante a rapidez na circulação do correio (Fotografia 11). Esse objeto técnico dispensa grande quantidade de mãode-obra, necessitando apenas de trabalhadores para a indução das encomendas e para a retirada no final do processo. Inicialmente, a máquina realiza a leitura do código de barras da etiqueta do objeto postal por meio de um scanner infravermelho suspenso, ao mesmo tempo em que calcula o seu peso e volume e cruza esses dados com as informações lidas na etiqueta, que foram adicionadas no sistema online no momento da postagem. No mesmo instante, o autômato identifica, também por meio do código de barras, o CEP de destino da encomenda, informação essencial para a triagem dos objetos. Todo esse procedimento dura apenas um segundo para ser realizado com cada objeto. Na sequência, a encomenda passa a circular por centenas de metros de esteiras rolantes, até que a própria máquina a derruba em uma das 152 rampas de saída, cada uma delas correspondendo a uma faixa de CEP relacionada a uma região de destino no Brasil. A definição de cada rampa depende do cálculo da média de correspondência por hora para cada destino. Por exemplo, há uma rampa dedicada às encomendas de todo o estado de Roraima; outra rampa recebe somente encomendas para a Região Metropolitana de Recife; outra comporta apenas encomendas para a zona oeste da cidade do Rio de Janeiro. As rampas são agrupadas em quatro grupos principais conforme a demanda de envio de encomendas desde o CTE Jaguaré, que são também zonas de trabalho dentro da unidade operacional dos Correios: A) destinos do interior de São Paulo, Rio de Janeiro e Espírito Santo; B) outros destinos do interior de São Paulo, parte do Rio de Janeiro, Minas Gerais e a Região Sul do Brasil; C) idem ao item B; D) regiões Norte, Nordeste e Centro-Oeste do Brasil. Essa racionalização interna já aponta para um consumo desigual de encomendas postais no país.

No caminho, cada pacote passa ainda por uma célula de raio $\mathrm{X}$, que identifica objetos suspeitos (armas, explosivos, drogas, etc.), separando-os em caso afirmativo e enviando imediatamente a informação para um sistema da Polícia Federal, que comparece ao local para averiguar a suspeita. Esse procedimento revela os limites do princípio de inviolabilidade quando se trata de segurança na logística postal. Por trás de todo esse gigantesco aparato que lembra uma esteira de produção industrial fordista (apesar de não haver correspondência entre

${ }^{137}$ Também denominado $e$-commerce. 
os procedimentos adotados e os métodos do Fordismo), há uma sala de controle equipada com computadores potentes e uma equipe de técnicos que acompanha o funcionamento da máquina, sendo que ela mesma avisa quando uma rampa está cheia e deve ser esvaziada por um funcionário ou quando há problemas na operação. A meta do CTE Jaguaré é garantir a triagem de nove mil objetos por hora com o uso da máquina.

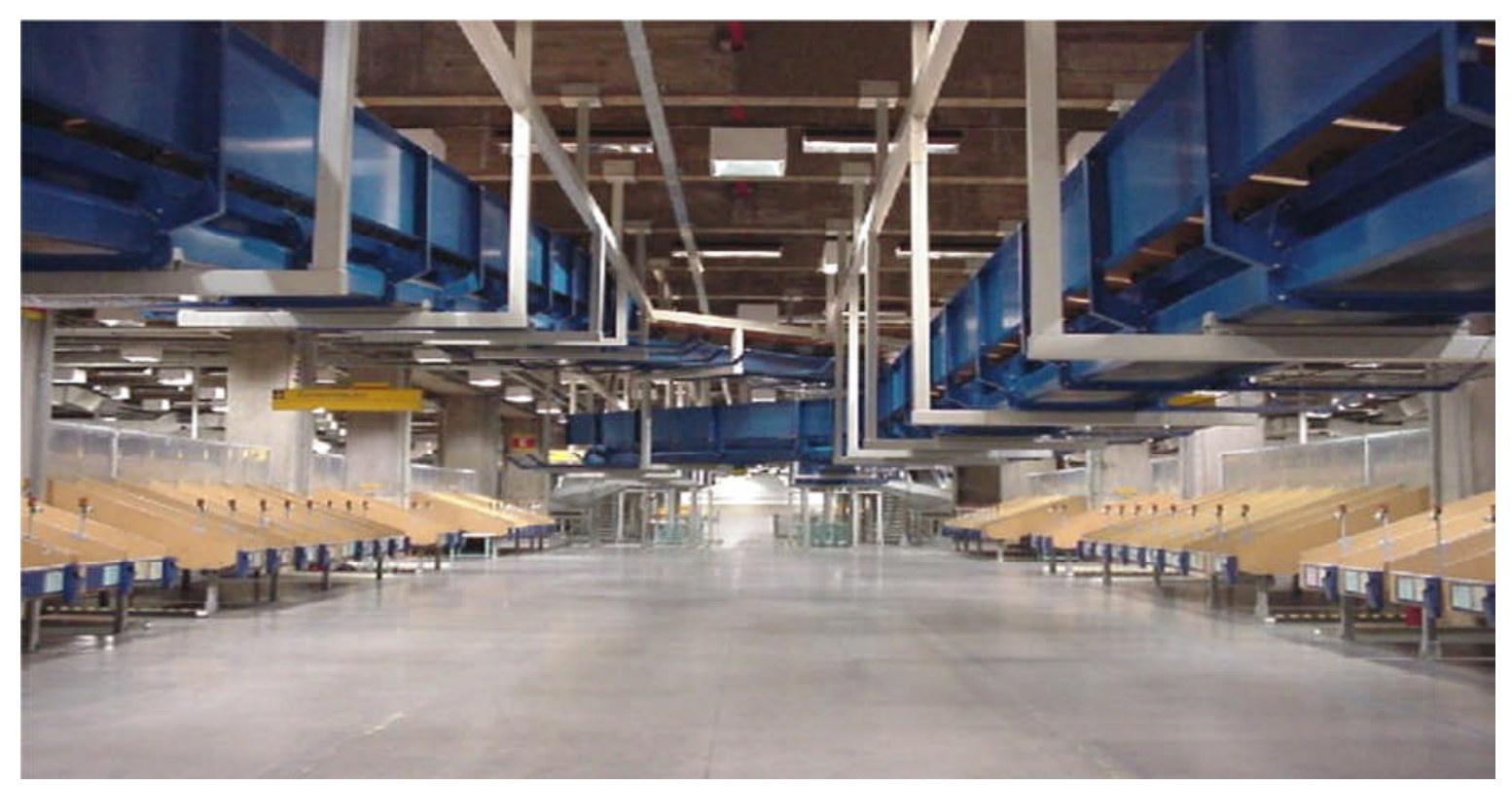

Fotografia 11 - Máquina de triagem de objetos do CTE Jaguaré, São Paulo-SP. Na foto aparecem as esteiras rolantes (suspensas, em azul) e as rampas de saída dos objetos por destino (no chão, em amarelo).

Fonte: Imagem cedida pelos Correios durante trabalho de campo no CTE Jaguaré em março de 2015.

Mas a máquina de triagem só permite o tratamento dos objetos do tipo encomenda, que por seu acondicionamento podem passar por todo o processo sem sofrer danos. Os envelopes, do segmento mensagem, continuam sendo separados manualmente por uma grande equipe de funcionários dos Correios, que possui metas de trabalhos que correspondam à velocidade da máquina. Aí estão incluídos também todos os objetos SEDEX postados em envelopes; objetos não maquináveis, geralmente de dimensões que extrapolam a capacidade da máquina; e objeto em devolução, cujo destino passa a ser o CEP de origem, podendo gerar confusão na leitura feita pela máquina. Interessante também é assinalar a exclusão do tratamento automático das encomendas do tipo SEDEX Hoje e SEDEX 10, que, por terem encaminhamento prioritário e deixarem o centro logístico antes dos demais objetos, não podem ser misturados na máquina.

No âmbito externo, os Correios mobilizam uma série de fixos geográficos, incluindo desde unidades de atendimentos - as agências - até unidades operacionais especializadas, localizados em diferentes pontos do espaço, articulando-os por meio de uma eficiente rede de 
transporte. Os procedimentos internos aos centros de tratamento devem ser integrados aos procedimentos externos, por meio da correlação entre o tipo de objeto (por segmento e velocidade) e o seu local de destino.

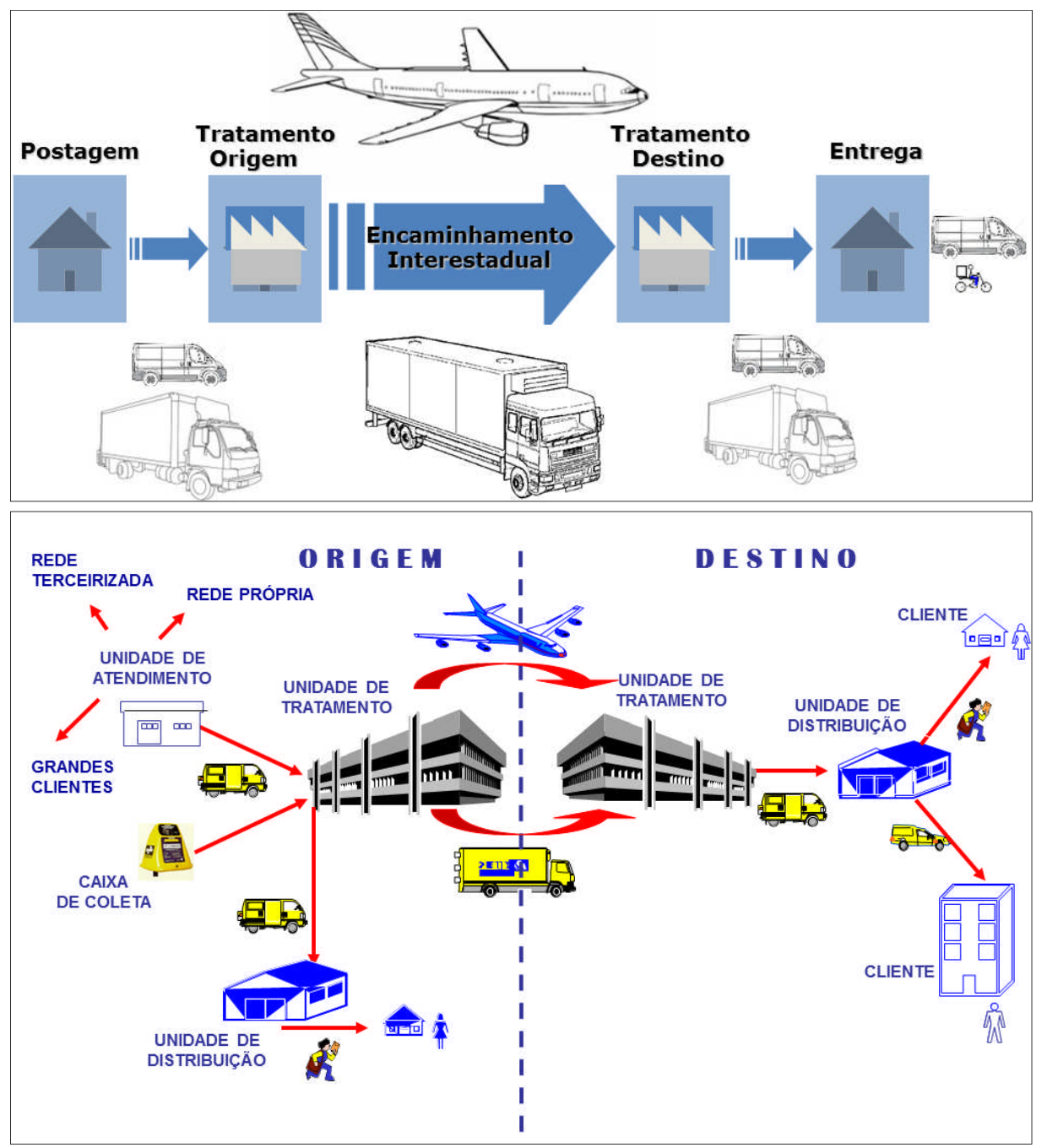

Fluxograma 1 - Modelo simples e detalhado do esquema de captação e entrega dos Correios, 2015. Fonte: GENAF/Correios

Inicialmente, as unidades de atendimento realizam a coleta dos objetos por meio dos procedimentos de postagem. Esse atendimento pode ser realizado num canal convencional, ou seja, uma agência própria ou terceirizada dos Correios, ou diretamente por meio do depósito do objeto já selado numa caixa de coleta. No caso de grandes clientes, especialmente as empresas de e-commerce, a postagem pode ser realizada na própria empresa por procedimentos eletrônicos (ver item 3.3). Em seguida, todos os objetos postados seguem para uma unidade de tratamento próxima ao local de origem, geralmente pelo modal rodoviário, onde passam pelos procedimentos internos anteriormente detalhados. A seguir, a 
correspondência segue para outra unidade de tratamento, desta vez próxima ao local de destino, valendo-se do modal aéreo para os serviços expressos e o rodoviário para o não expresso. Após passar novamente pela triagem, o objeto é encaminhado para uma unidade de distribuição, de onde seguirá para entrega por meio de um carteiro a pé em veículo motorizado (Fluxograma 1).

A estratégia logística dos Correios se torna mais compreensível se agregarmos a localização dessas unidades de atendimento, tratamento e distribuição no território (Fluxograma 2). As agências - esses fixos mais básicos - estão localizadas em todas as cidades, correspondendo a uma unidade de atendimento, no caso das pequenas cidades, ou ao bairro, para as cidades maiores. Já para as unidades de tratamento existem vários níveis intermediários, sendo que primeiro as correspondências seguem da agência para uma unidade regional, que geralmente se localiza em cidades médias ou nas áreas centrais das maiores cidades, e em seguida uma unidade estadual congrega todas as correspondências do respectivo estado, oriundas das unidades regionais. Todo esse procedimento é realizado prioritariamente pelo modal rodoviário, sendo que a partir daí as correspondências seguem pelo modal aéreo para unidades de tratamento automatizadas em algumas poucas cidades do país, que redistribuem as correspondências refazendo todo o caminho de volta até alcançar as unidades de distribuição, que assim como as de atendimento estão localizadas em todas as pequenas cidades e bairros das cidades maiores. Esses centros automatizados são fixos postais altamente especializados, sendo que a cidade de São Paulo é a única a dispor de três deles. As seguintes cidades possuem um fixo cada: Campinas, Rio de Janeiro, Belo Horizonte, Curitiba, Londrina, Florianópolis, Porto Alegre, Brasília e Recife ${ }^{138}$.

Em pesquisa recente sobre os centros de tratamento dos Correios, Cruz (2007) concluiu que "a automatização de parte do processo de tratamento em unidades localizadas estrategicamente em regiões de alto volume de circulação de objetos trouxe melhorias à área operacional de encomendas", viabilizando redução no tempo gasto nessa etapa, diminuição de erros no processo, entre outros.

\footnotetext{
${ }^{138}$ Dentre essas cidades, somente São Paulo, Rio de Janeiro e Belo Horizonte possuem centros logísticos equipados com máquinas de triagem de esteira dupla, com maior capacidade operacional.
} 


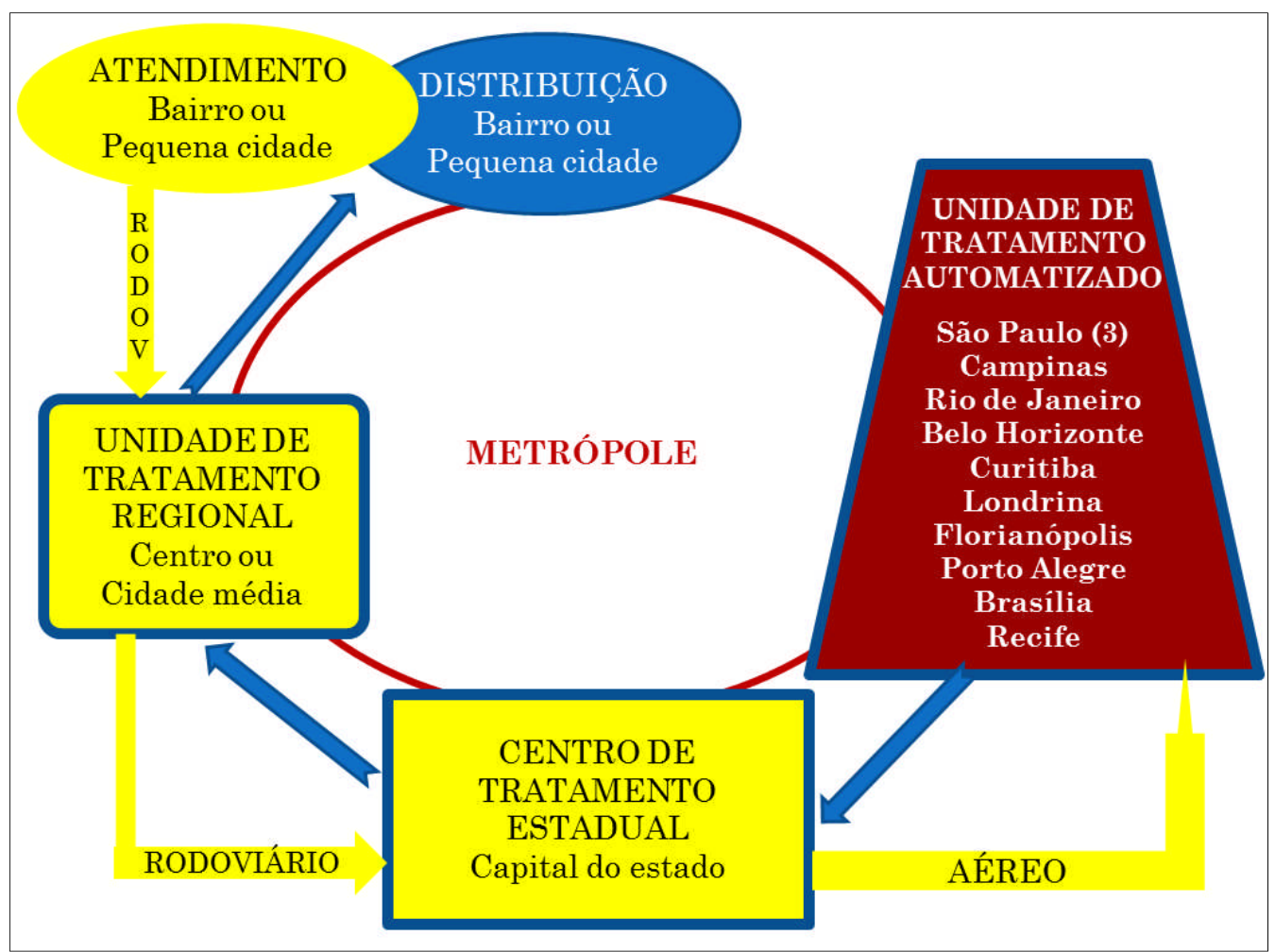

Fluxograma 2 - Esquema geográfico da logística dos Correios no Brasil, 2016.

Fonte: Elaboração própria a partir de trabalhos de campo no CTE Jaguaré em outubro de 2014 e março de 2015.

A estratégia atual dos Correios revela estreita relação com uma trama escalar, muito mais complexa que a apresentada por Gertel (1991) há duas décadas. Atualmente as unidades de atendimento e distribuição realizam procedimentos na escala local, sendo que a unidade de tratamento da região é responsável pelos fluxos da escala regional. De tal modo que apenas as unidades automatizadas operam na escala nacional, recebendo e encaminhando objetos para outros estados. As metrópoles, especialmente as cidades com unidades de tratamento automatizado, ocupam uma posição privilegiada nessa logística, pois reúnem no mesmo lugar todos os tipos de fixo postal e podem, assim, economizar no tempo de transporte entre as unidades dos Correios e garantir, a partir de sua localização, maior velocidade dos fluxos em relação ao restante do território.

\subsection{O papel da informação na logística postal}

A informação, como variável-chave do período, assume um protagonismo na logística dos Correios, autorizando a sincronização das ações e o controle de todo o processo de circulação. É a informação que permite que os agentes envolvidos na logística postal - o remetente, os Correios e o destinatário - sejam articulados em rede. Mesmo que tenha sempre 
sido parte do serviço postal (não é possível falar em correio sem informação), é neste período que pode ser notada sua maior relevância.

O elo que une o remetente e o destinatário, antes mesmo do próprio objeto postal, é a informação. Na verdade, a informação chega ao destinatário muito antes de sua carta ou encomenda, pois as tecnologias do presente já o autoriza a acompanhar o objeto durante todas as etapas da operação logística. Além disso, o processo não se encerra no ato da entrega, pois o remetente recebe de volta a informação que revela o status da entrega, com data, horário, nome e documento do recebedor. Esse procedimento virtualiza, de alguma maneira, o serviço ainda vigente do Aviso de Recebimento (AR), um formulário físico que volta ao fluxo postal com a assinatura do destinatário e é entregue ao remetente como comprovante de entrega ${ }^{139}$. Pode-se afirmar, assim, que os fluxos imateriais são tão importantes quanto os fluxos materiais na logística dos Correios, já que não basta colocar o objeto postal em circulação, devendo acompanha-lo e produzir informações sobre ele a todo instante e em todos os lugares por onde passar.

No entanto, os serviços também se diferenciam pela intensidade dos fluxos informacionais. O SEDEX é o único serviço a contar com o rastreamento ponto-a-ponto, ou seja, em todos os lugares por onde passa, sendo que serviços como o PAC e a carta registrada são rastreados somente nas etapas de postagem e entrega. Como "o ideal do poder é agir em tempo real" (RAFFESTIN, 1993, p.201), os agentes que se valem do SEDEX para envio de mensagens e encomendas têm mais condições de exercer o controle sobre as suas remessas, permitindo também maior velocidade na tomada de decisões e a antecipação de ações futuras.

A precisão no rastreamento dos objetos expressos, bem como o controle estrito sobre a velocidade com que circulam, somente tornou-se possível a partir da lógica do CEP. Como grande integrador da logística dos Correios, o CEP permite alimentar constantemente os sistemas de informação com a localização exata dos envelopes e encomendas SEDEX, de qualquer ponto do país. O CEP é uma tecnologia de racionalização do espaço que congrega, sob a lógica dos números, diversas escalas geográficas, do nacional ao local, permitindo identificar desde o estado até o bairro e o logradouro exato do endereço pretendido (Anexo A). No sistema decimal do CEP, os três últimos números correspondem à localização numa escala grande, chegando ao nível do logradouro, que somente foram adicionados anos após a introdução de um sistema inicial de cinco algarismos (Figura 10).

\footnotetext{
${ }^{139}$ Para o sistema judiciário brasileiro, o AR dos Correios é o único comprovante legal de recebimento de uma correspondência.
} 


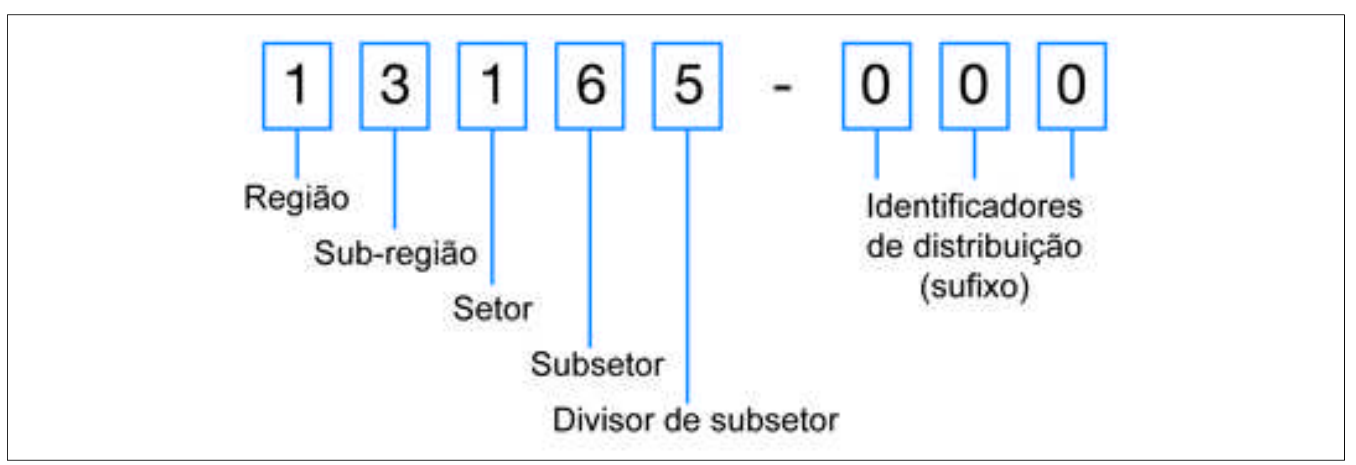

Figura 10 - Estrutura do CEP no Brasil.

Fonte: Website dos Correios, no endereço https://www.correios.com.br/para-voce/precisa-de-ajuda/o-que-e-cepe-por-que-usa-lo/estrutura-do-cep.

Analisando apenas a divisão nacional que corresponde ao primeiro algarismo, os números revelam uma divisão do Brasil em dez regiões, cada uma delas comandada por uma cidade principal, a partir de onde os demais CEPs são derivados. Na ordem do numeral 0 até o 9, são elas: São Paulo, Santos, Rio de Janeiro, Belo Horizonte, Salvador, Recife, Fortaleza, Brasília, Curitiba e Porto Alegre. Essa regionalização foi elaborada tendo como localidadebase a cidade de São Paulo (Mapa 11), numa ordem espiral crescente em sentido anti-horário, revelando a predominância das principais metrópoles do país como referências para a implantação do CEP.

Hoje os Correios contam com a tecnologia denominada $e$-CEP, que realiza o envio do número do CEP respectivo de cada objeto diretamente do sistema da agência para a máquina de triagem no momento da postagem, acelerando a circulação dos objetos. Desta maneira, a informação sobre o destino respectivo de cada encomenda chega à máquina em tempo real, muito antes que o próprio objeto postal. Como cada objeto possui um número específico no código de barras, ao passar na esteira rolante a máquina já associa o objeto ao respectivo destino, em milésimos de segundo. Anteriormente era necessária a digitação manual de todos os CEPs para a triagem, o que retardava a operação. 


\section{Município de São Paulo: Faixas de CEP, 2016}

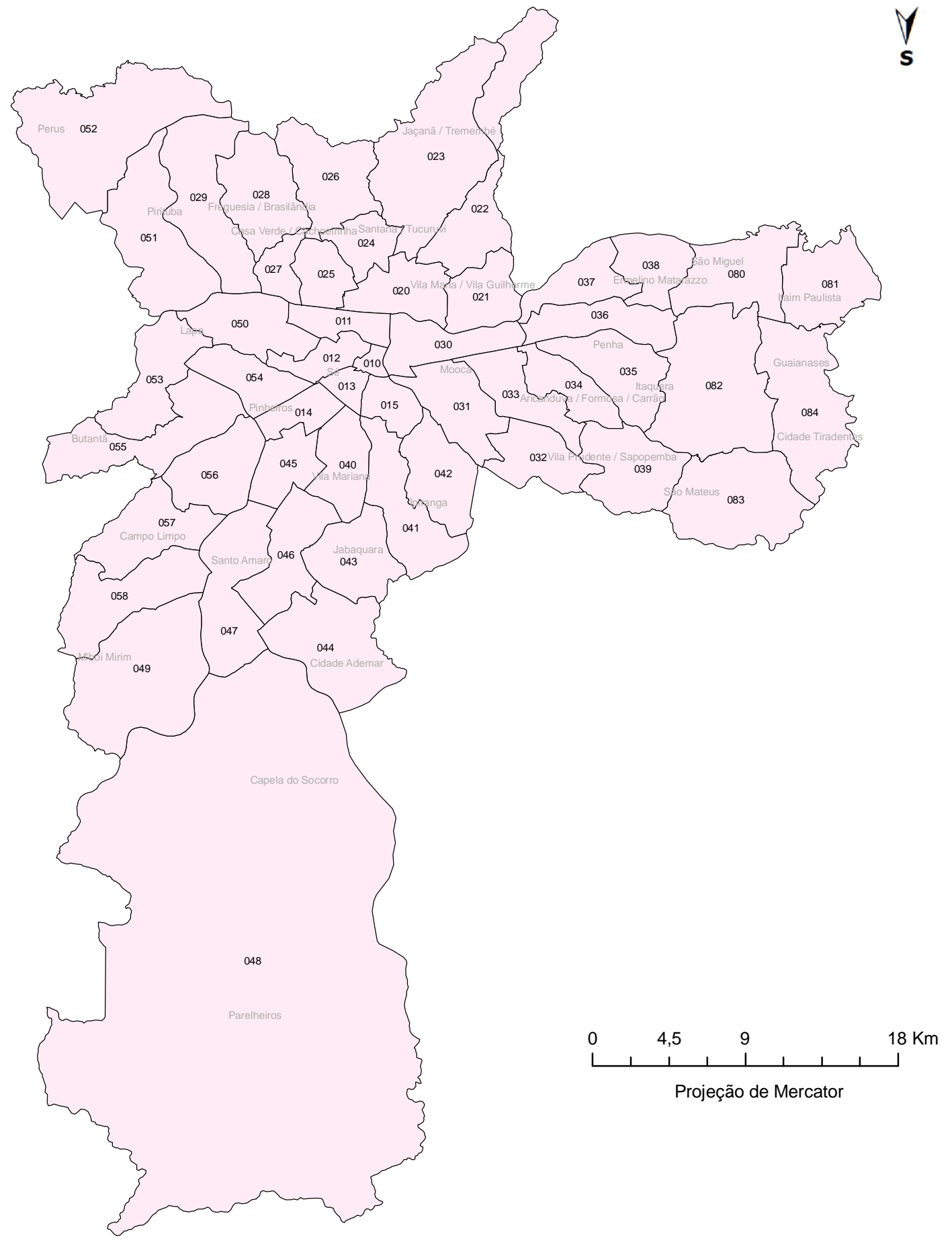

Base cartográfica: CEM Elaboração: Igor Venceslau

Mapa 11 - Município de São Paulo: faixas de CEP, 2016. Nomenclaturas ao fundo: subprefeituras de São Paulo. Fonte: Elaboração própria a partir de dados do Centro de Estudos da Metrópole. 
A racionalização dos procedimentos atinge também cada objeto postal, que atualmente também se transformou em número. Com a utilização da etiqueta lógica (com código de barras), cada carta ou encomenda é identificada pelo seu respectivo código, que contém números e letras; cada código é único e não existem dois objetos com códigos idênticos, incluindo os já entregues. A criação dos códigos também obedece a uma normatização internacional, onde as primeiras letras correspondem ao tipo de objeto e as últimas indicam o país de origem. Por exemplo, no código "SX123456789BR", as duas primeiras letras informam que é um objeto do tipo SEDEX 10 e as últimas indicam que é um objeto do correio do Brasil ${ }^{140}$. Aqui, faz sentido para o correio a máxima de Marshall McLuhan de que "o meio é a mensagem", pois de mediador e invólucro da informação sigilosa, o objeto postal se torna informacional, uma informação banalizada.

O código do objeto é uma espécie de senha identificadora necessária em todas as etapas. No ato da postagem, quando a etiqueta é aplicada ao objeto, o código é inserido num sistema online que já comunica a sua existência a todas as demais unidades dos Correios por onde ele irá passar até a entrega, permitindo a previsão exata do volume de trabalho em cada local. A tecnologia também permite antecipar possíveis casos de superlotação ou diminuição no fluxo normal da rede, possibilitando reelaborar diariamente a estratégia logística e diminuir custos.

O código do objeto também é necessário para o seu rastreamento, sendo indicado no comprovante de postagem para o remetente. Com ele, é possível que o remetente, o destinatário ou qualquer outra pessoa realize o acompanhamento ponto-a-ponto dos procedimentos dos Correios, no caso dos serviços expressos. Para isso, os Correios criaram o Sistema de Rastreamento de Objetos (SRO), que é alimentado automaticamente por todas as unidades da empresa a cada vez que a etiqueta com código de barras é lida num scanner de computador ou máquina de triagem. E já que "o ideal do poder é ver sem ser visto" (RAFFESTIN, 1993, p.202), esse mesmo sistema permite encontrar rapidamente objetos extraviados, mas também é utilizado para identificar possíveis erros ou atrasados cometidos por um funcionário e aplicar as punições previstas. É possível acessar no SRO as informações referentes a data, horário e local de cada evento sofrido pelo objeto, que ficam disponibilizadas online por tempo indeterminado (Figura 11).

\footnotetext{
${ }^{140}$ Para ter uma noção aproximada da complexidade técnico-informacional que envolve a logística dos Correios, há 184 tipos diferentes de siglas para as duas primeiras letras do código do objeto, o que na prática significa 184 serviços diferentes e 184 tipos diferentes de etiquetas lógicas adesivas disponíveis nas agências para serem adicionadas ao objeto, conforme o serviço solicitado. Para uma lista completa dessas siglas e seus significados, acessar https://www.correios.com.br/para-voce/correios-de-a-a-z/rastreamento-de-objetos.
} 
27 CORREIOS PG096307974BR - Histórico do Objeto

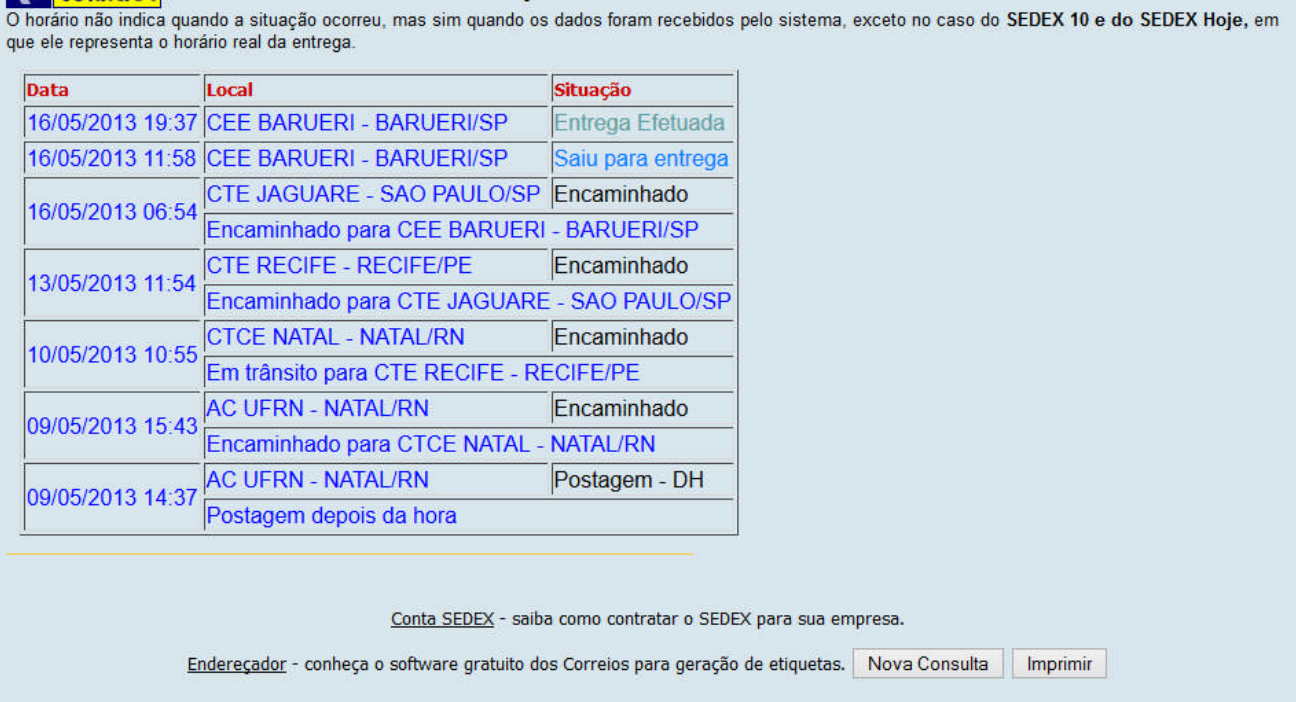

Figura 11 - Interface do Sistema de Rastreamento de Objetos dos Correios.

Fonte: Adquirida em trabalho de campo no CTE Jaguaré, São Paulo-SP, em março de 2015.

Não somente as correspondências podem e são rastreadas. O rastreamento inclui todos aqueles outros objetos que participam da circulação geral dos Correios. As caixetas que agregam correspondências dentro de veículo são fechadas com lacres com código de barras e sofrem rastreamento ponto-a-ponto. Igualmente, os contêineres que transportam um volume maior de encomendas dentro das aeronaves de carga recebem o mesmo tratamento. Motocicletas, veículos em geral, caminhões, aviões, barcos, todos eles são rastreados pelos Correios a todo instante, informação essencial para que os sistemas de entrega rápida, como o SEDEX, possam funcionar da maneira sistêmica. Com a introdução da tecnologia de smartphones na etapa da entrega das correspondências, que hoje ainda é feita em muitos lugares por meio de lista manual com inserção dos dados no SRO somente quando o carteiro retorna à unidade dos Correios, tornou-se possível a informação em tempo real sobre a entrega, acelerando todo o processo, mas também possibilitando o rastreamento do próprio carteiro e o controle mais rígido do seu tempo de trabalho.

O uso da informação tem transformado mais do que a circulação dos objetos postais. Com as soluções de postagem eletrônica, tornou-se possível acelerar e racionalizar a postagem para clientes corporativos ou instituições governamentais. No serviço de $e$-Carta, por exemplo, o remetente encaminha o conteúdo da mensagem para os Correios por meios eletrônicos, e a empresa se responsabiliza de todo o restante: impressão, envelopamento, postagem e entrega. Já o $e$-SEDEX foi criado para atender demandas do comércio eletrônico, isentando o remetente de comparecer a uma agência de postagem. Estratégias semelhantes 
foram destacadas por Aguilar Pérez (2004) no caso empresas europeias de correio, ao que o autor denomina de "correio híbrido", serviço que permite passar do virtual ao físico.

Os sistemas integrados de softwares, como o SRO, são indispensáveis para a coleta e transmissão das informações. Os Correios operam com uma grande quantidade de sistemas operacionais que funcionam online de maneira integrada, gerando compartilhamento de informações. O Sistema de Automação da Rede de Atendimento (SARA) capta os dados das agências no ato da postagem, necessários às etapas seguintes, enquanto no SRO são inseridos dados das unidades de tratamento e entrega. As unidades de tratamento automatizado dispõem também do Sistema Local do Centro de Tratamento de Encomendas (SILCTE), que coleta constantemente dados de quantidade e volume dos objetos triados e encaminhados. Por sua vez, o Sistema de Postagem Eletrônica (SPE) é uma ferramenta que oferece a comodidade de realizar postagens de telegramas e cartas por pessoas jurídicas sem a intermediação das agências. Para os clientes do serviço de malote, o sistema Malote Web permite consultar a situação do objeto, solicitar novos percursos ou alterar os existentes, solicitar faturas de pagamento dos contratos, entre outros. Já o Sistema de Gerenciamento de Postagem (SIGEP) permite a impressão de etiquetas no computador do próprio remetente e está disponível para clientes do comércio eletrônico; desta maneira, a encomenda já fica pronta no próprio endereço do cliente, onde os Correios realizam a coleta em veículo próprio e transportam diretamente a uma unidade de tratamento. Assim, a postagem de grandes clientes acontece no momento em que o objeto é induzido na máquina de triagem, realizando simultaneamente os procedimentos de postagem, triagem e expedição. Todos esses sistemas são inovações tecnológicas que aumentam a produção de informações, que por sua vez permitem acelerar os fluxos materiais das cartas e encomendas.

O serviço de logística reversa ${ }^{141}$ é ilustrativo do papel central da informação nos Correios. Como o próprio nome sugere, o serviço visa a devolução de objetos recebidos pelo destinatário e que necessitam por algum motivo voltar às mãos do remetente. É utilizado principalmente em casos de defeito de mercadorias adquiridas no comércio eletrônico, sendo devolvidas para troca ou manutenção. Neste caso, a empresa de e-commerce fornece a seus clientes um código que autoriza a postagem do objeto em qualquer agência dos Correios, sem custos para quem envia. Na agência, ao se inserir o referido código, que pode ser utilizado somente uma vez, o sistema informa qual é o endereço de destino, o peso e as dimensões da encomenda, bem como o nome, endereço, telefone e CPF do remetente autorizado.

\footnotetext{
${ }^{141}$ O termo é empregado pelos Correios no sentido de logística reversa "pós-venda" e não como utilizado em outras atividades relacionadas à logística de resíduos e à reciclagem.
} 
Conforme crescem a demanda, a produção e o consumo de informações, aumenta também a necessidade de organizar todo esse aparato informacional. Até aqui, evidenciamos as transformações nos planos técnico e informacional que afetaram o correio brasileiro, marcando definitivamente o período contemporâneo. A ciência é outra variável-chave do meio técnico-científico-informacional, funcionando sistematicamente com as demais. É nesse contexto que é criada a Universidade Corporativa dos Correios (UniCo) ${ }^{142}$, uma instituição educacional da empresa ${ }^{143}$, com campus em Brasília-DF, que desempenha uma série de atividades com impacto em toda a rede postal (Fotografia 12). Ela é o setor responsável em transformar a informação banal em informação científica, tratando-a e distribuindo por todos os canais da empresa. Ao mesmo tempo, também produz informação por meio de pesquisas e parcerias com outras instituições científicas.

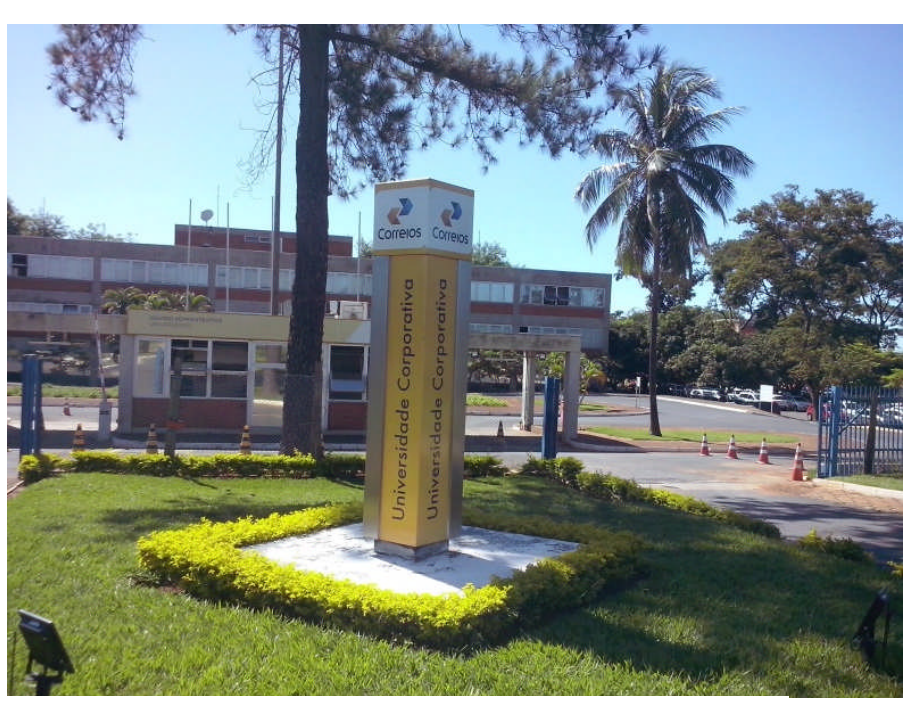

Fotografia 12 - Campus da Universidade Corporativa dos Correios, em Brasília-DF. Fonte: Trabalho de campo realizado na UniCo em março de 2016.

Foto: Igor Venceslau.

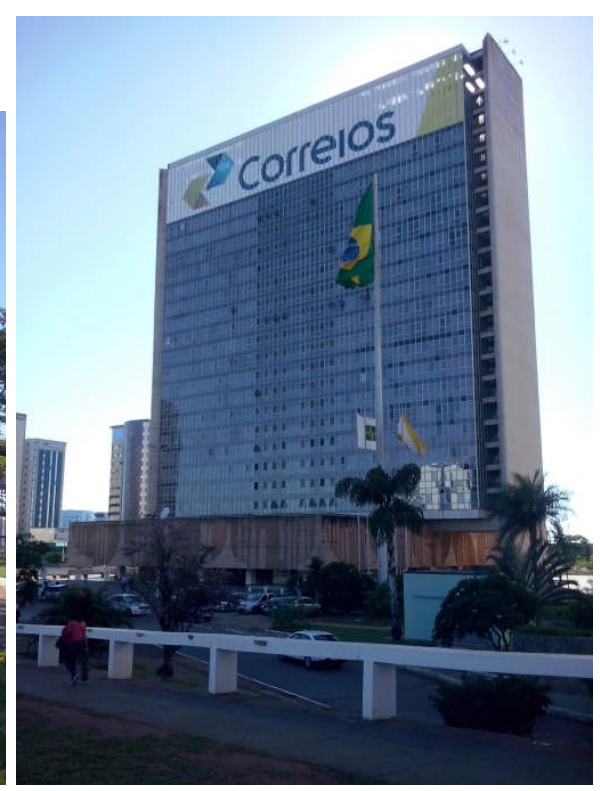

Fotografia 13 - Edifício-sede dos Correios, em Brasília-DF.

Fonte: Trabalho de campo realizado na sede da empresa em março de 2016.

Foto: Igor Venceslau.

A Universidade Corporativa dos Correios foi criada em 2001, um marco da passagem da empresa para o século XXI, mas sua origem remonta à Escola Superior de Administração Postal, hoje extinta, fundada em 1977-1978, no bojo de grandes transformações no correio a partir da transferência da sede do Rio de Janeiro para a capital federal (Fotografia 13). Para Oliveira (2007), “a criação da universidade corporativa dos Correios veio agregar valor à

\footnotetext{
142 Apesar da nomenclatura, essas instituições corporativas se diferenciam das tradições universidades, cujas atividades são mais amplas e estão alicerçadas no tripé ensino-pesquisa-extensão.

${ }^{143}$ No Brasil, as empresas públicas Caixa Econômica Federal, Banco do Brasil e Petrobrás também possuem suas universidades corporativas.
} 
empresa por fortalecer suas bases e oferecer uma nova abordagem educativa". A universidade é o cérebro de todo o sistema de conhecimento da empresa, já que atua em diversas frentes, conhecidas como "eixos"144:

- Eixo A: treinamento inicial para todos os funcionários;

- Eixo B: formação continuada, a depender da necessidade e do cargo exercido;

- Eixo C: concessão de bolsas de estudo (graduação, pós-graduação e idiomas).

A Internet possibilitou à UniCo realizar o treinamento dos funcionários no próprio local de trabalho, por meio do acesso a plataformas específicas para este fim ${ }^{145}$. Esse novo procedimento permite a aceleração da velocidade na difusão de informação e conhecimento especializado, garantindo o funcionamento sistêmico das ações nos Correios e a otimização de seus processos logísticos. Apesar de localizada na capital federal, a UniCo coordena e executa, em escala nacional, a gestão de informações e conhecimento, consolidando-se como o núcleo de inteligência dos Correios.

\subsection{Os prazos de entrega dos Correios no Brasil: fluidez e viscosidade territorial}

A racionalidade empregada pelos Correios dentro e fora da firma, conectando suas unidades por meio de sistemas geradores e organizadores de fluxos informacionais ininterruptos, se desdobra no aumento da velocidade dos fluxos materiais. Os serviços expressos demandam um conjunto significativo de complexas informações em todas as etapas, ao mesmo tempo em que geram mais informação durante o processo, retroalimentando a própria logística. Somente a partir desses sistemas informacionais e da instantaneidade por eles proporcionada é que o objeto postal pode circular com a rapidez que conhecemos hoje. Contudo, como o território não é homogêneo e suas desigualdades não são eliminadas pela difusão do meio técnico-científico-informacional, o período atual conhece uma contradição entre a instantaneidade dos fluxos informacionais e a multiplicação das diferentes velocidades do fluxo postal. Deste modo, se a informação pode alcançar os diferentes lugares praticamente em tempo real, as cartas e encomendas são entregues com diversos graus de defasagem no território.

As diferentes velocidades com que os objetos postais circulam se desdobram em diferentes prazos de entrega oferecidos pelos Correios. Para compreendê-los, faz-se

\footnotetext{
${ }^{144}$ Informações adquiridas em trabalho de campo realizado no campus da Universidade Corporativa dos Correios (UniCo), em Brasília-DF, em março de 2016.

${ }^{145}$ Informação adquirida por meio de entrevista aplicada ao diretor executivo da UniCo em março de 2016.
} 
necessário considerar a materialidade do território e suas implicações para a circulação, principalmente os modais de transporte e o uso das infraestruturas disponíveis. Os transportes devem ser considerados como um élément des systèmes géographiques (elemento dos sistemas geográficos), conforme indicado por Brunet (1993), integrados aos sistemas produtivos e à circulação de bens e pessoas em todas as escalas.

\subsubsection{Os modais de transporte na logística dos Correios}

Para o transporte de malas postais, os Correios se valem da distinção de objetos por sua velocidade, ou seja, em expressos e não expressos. A depender do tipo de objeto, os prazos de entrega são diferentes e as estratégias logísticas para atingi-los também se diferenciam. Assim, cada tipo de objeto postal exige modais de transporte específicos que possibilitem articular os lugares numa rede mais ou menos veloz, com impactos também sobre o preço individual de cada serviço.

Para Barat (2011, p.218), "as infraestruturas de transporte, em seus diversos modais, constituem o principal suporte para as atividades relacionadas com a logística”. Esses modais de transporte estão amparados na infraestrutura disponível no território, na maioria dos casos construída a partir de investimentos do Estado. Assim, aplicando uma distinção utilizada pela geógrafa Leila Dias ([1996] 2010), as redes de transporte - rodoviária, aérea, fluvial constituem a "rede-suporte", ou seja, a infraestrutura necessária de uma "rede-serviço" que é o próprio serviço postal.

O modal ferroviário já fora substituído pelo rodoviário há algumas décadas para o transporte de carga postal, este hoje o mais utilizado pelos Correios, dada a maior disponibilidade da infraestrutura de rodovias. Para todos os serviços não expressos o transporte é feito por superfície, ou seja, utilizando o modal rodoviário e, quando for o caso, o modal hidroviário. Já os serviços expressos usam o modal aéreo como estruturador de uma rede nacional e o modal rodoviário ou hidroviário como complementar nas escalas regional e local. Desta maneira, é possível cumprir os prazos rápidos do SEDEX (incluindo as variantes 10, 12, Mundi e Hoje) em todo o Brasil. É importante assinalar, contudo, que não se trata de logísticas separadas para cada tipo de serviço: é a mesma estratégia logística que lida com ações variadas, mas complementares, por conta da diversidade de prazos que precisa cumprir. Deste modo, num mesmo veículo são transportadas cargas expressas e não expressas, sendo que a expressa tem tratamento prioritário. 
A rede de transporte rodoviário dos Correios está estruturada no que a empresa denomina de Linhas Tronco (LT), divididas conforme a escala de alcance em:

- Linhas Tronco Internacionais (LTI) - realizam o transporte de carga não expressa para alguns países vizinhos, como Argentina, Paraguai e Bolívia;

- Linhas Tronco Nacionais (LTN) - realizam o transporte interestadual de carga postal, principalmente não expressa;

- Linhas Tronco Regionais (LTR) - transportam cargas expressas e não expressas entre localidades do mesmo estado;

- Linhas Tronco Auxiliares (LTA) - utilizam linhas regulares de ônibus de passageiros para transporte de carga entre localidades próximas, geralmente pequenas cidades, onde a baixa demanda não justifica a criação de uma $\operatorname{LTR}^{146}$;

- Linhas de Coleta e Entrega (LCE) - rede local para coleta e entrega de carga entre unidades dos Correios da mesma cidade;

- Linhas Tronco Urbanas (LTU) - realizam todos os tipos de entrega local dentro das cidades nos domicílios dos destinatários.

$\mathrm{Na}$ maioria dessas linhas, principalmente as nacionais e regionais, são utilizadas empresas terceirizadas para o transporte rodoviário de carga. No entanto, pela estratégia logística empregada, os Correios continuam mantendo a sua posição como um agente que opera em toda a cadeia, desde a origem com a captação da carga até a sua entrega ao "cliente" final, como demonstrou Huertas (2013) em estudo recente.

Com as LTs, os Correios conseguem atingir quase todas as cidades do país, nas diversas escalas. Os nós dessa rede rodoviária são cidades que se localizam na encruzilhada dos fluxos postais, reconhecidos pontos de encontro das principais rodovias brasileiras: São Paulo, Rio de Janeiro, Brasília e Feira de Santana. As três primeiras cidades são também a origem de boa parte do fluxo postal, o que também justifica o papel de centralidade que ocupam. Rio de Janeiro, primeiro, e depois São Paulo, se consolidaram como centralidades para os fluxos de correio ao longo da história brasileira. Brasília alcançou mais recentemente essa posição com a consolidação das novas rodovias radiais que partem do Distrito Federal para várias regiões do país. Quanto à cidade baiana de Feira de Santana ${ }^{147}$, sua situação de principal entroncamento rodoviário do Norte e Nordeste do país orientou a decisão dos

\footnotetext{
${ }^{146}$ Sobre o assunto vide estudo anterior (VENCESLAU, 2012), quando foi constatado que cerca de metade das pequenas cidades do Sul da Bahia recebem carga postal via linhas de ônibus de passageiros, com impactos sobre os prazos de entrega nesses lugares.

${ }^{147}$ Huertas (2013) revelou o papel central da cidade de Feira de Santana na Região Nordeste, conformando ao lado de Salvador um eixo nodal da rede nacional do transporte rodoviário de carga.
} 
Correios de implantar ali um centro de distribuição de carga não expressa para os estados da Bahia, Sergipe, Alagoas, Pernambuco, Paraíba, Rio Grande do Norte, Ceará e parte do Piauí.

Contudo, em regiões como a Amazônia, onde há muitas cidades sem ligação rodoviária, as hidrovias formam a rede de caminhos que permite à correspondência ser entregue e coletada em centenas de cidades ribeirinhas, impondo outro ritmo e outra temporalidade aos prazos de entrega. A Rede Postal Fluvial da Amazônia, criada em 1990, é uma alternativa complementar às LTs rodoviárias, utilizando embarcações dos mais variados tamanhos pelos rios da região. Duas linhas principais partindo de Belém, uma em direção a Manaus e outra com destino em Macapá, garantem a chegada da carga não expressa dos estados de Amapá e Amazonas. De Manaus, caminhões transportam os objetos destinados a Roraima até a sua capital Boa Vista. Outras linhas de barcos saem dos portos de Manaus, Macapá, Santarém, etc. para muitas cidades do interior da região. Em alguns casos, há também o fretamento de aeronaves para operar linhas aéreas regionais, como demonstrado por Queiroz (2015) para a cidade de Tefé-AM.

O modal aéreo, que permite conexões mais rápidas, só é possível ser empregado onde há infraestrutura aeroportuária instalada e demanda diária suficiente para justificar o frete de aeronaves $^{148}$, o que corresponde às capitais estaduais e apenas algumas cidades do interior do país. Na estratégia logística dos Correios, há sempre preferência pelo transporte de superfície, porque conta com maior regularidade e flexibilidade nas linhas, além de evitar problemas do modal aéreo como fechamento de aeroportos, condições climáticas, etc. O transporte por aeronaves, exclusivo para cargas expressas, somente é utilizado quando o transporte de superfície não permite o cumprimento do prazo.

Conforme observou o geógrafo francês Pierre George (1970, p.323), "a rapidez da circulação aérea desempenha, frequentemente, o papel de corretivo do custo real do transporte", ou seja, o preço mais elevado cobrado pelos serviços que utilizam o modal aéreo é compensado pela maior velocidade dos fluxos. Deste modo, atualmente o modal aéreo é utilizando pelos Correios somente para o serviço SEDEX, que é também o mais caro.

A Rede Postal Aérea Noturna (RPN) congrega as linhas aéreas dos Correios na escala nacional, levando e trazendo encomendas SEDEX por todo o país. As linhas partem de quatro nós, sendo São Paulo o principal deles, onde os Correios operam um grande terminal de carga no Aeroporto de Guarulhos. Os outros três pontos nodais da rede são Rio de Janeiro, no Aeroporto do Galeão, Brasília e Salvador (Mapa 12).

\footnotetext{
${ }^{148}$ Os Correios utilizam o fretamento de aeronaves de carga para o transporte aéreo, cujas empresas fretadas são escolhidas por meio de licitações públicas.
} 


\section{Brasil: Rede de transporte aéreo de carga dos Correios em 2016}

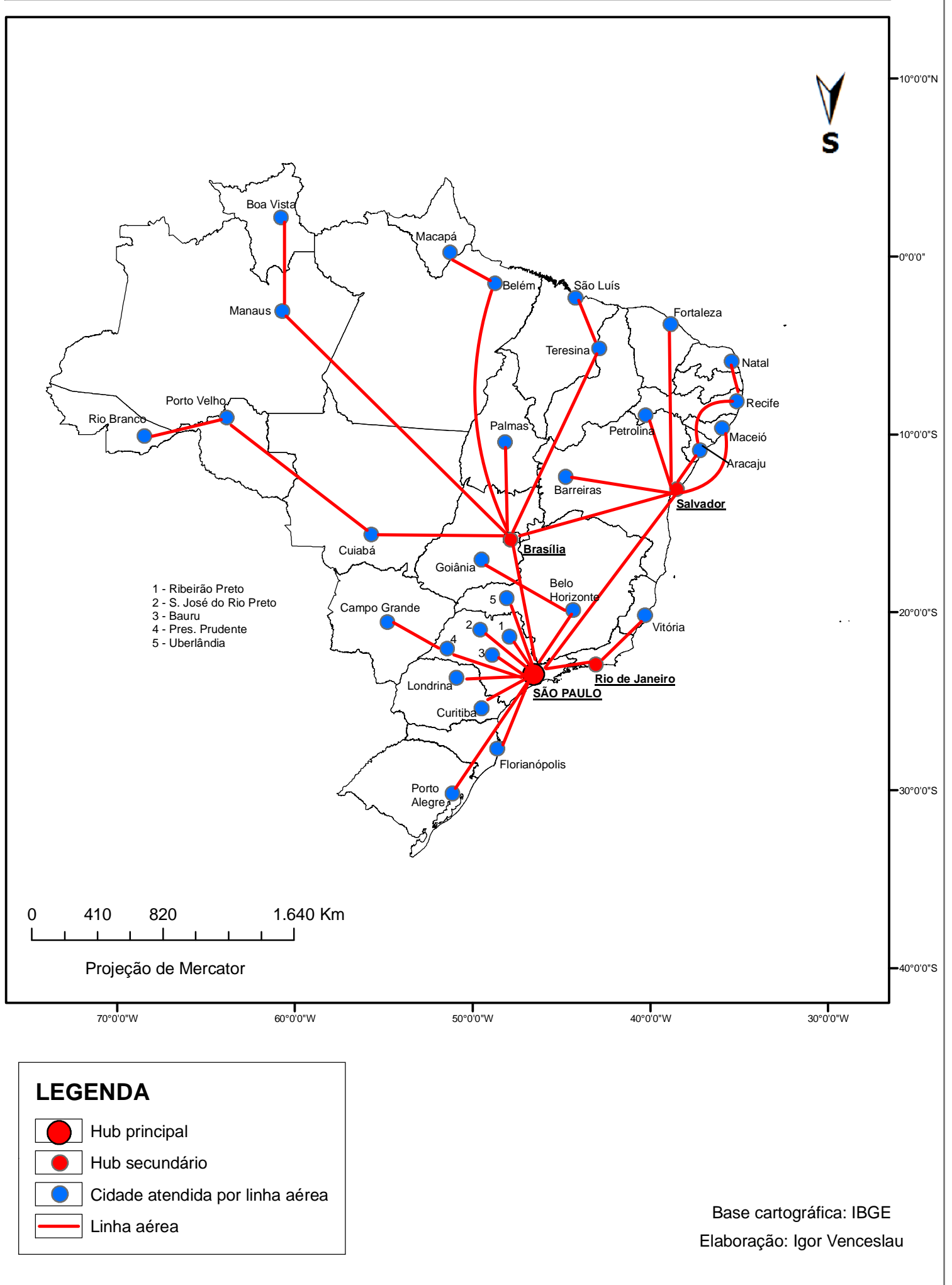

Mapa 12 - Brasil: rede de transporte aéreo de carga dos Correios em 2016.

Fonte: Elaboração própria a partir de dados do DENAF/Correios. 
Nesses nós, realiza-se o transbordo de carga postal já consolidada, sem necessidade de abrir as malas com as correspondências. Comparando-se a configuração atual com a mesma rede aérea há 70 anos (Figura 6), percebe-se que houve diminuição no número de cidades atendidas. Esse dado deve ser interpretado à luz da expansão e melhoria das rodovias brasileiras, pois apesar da redução na quantidade de cidades atendidas pelo modal aéreo, o serviço postal conheceu significativa expansão no período. Se naquele momento o projeto político era de integração nacional pelo avião, como bem apontou Moacir Silva (1949), hoje se trata de criar uma alternativa mais rápida de conexões para os serviços expressos. Em 1988, essa rede aérea servia 55 cidades, incluindo algumas que não são mais atendidas, como Ilhéus-BA, Tabatinga-AM e Santa Maria-RS (GERTEL, 1991).

Apesar de contar hoje com menor número de cidades atendidas, os Correios operam as linhas com frequência diária, o que fez com que a distância percorrida saísse de menos de 4 mil quilômetros em 1946 (Tabela 1) para chegar a 50 mil quilômetros por dia em 2015, segundo dados do Departamento de Encaminhamento e Administração da Frota (DENAF) dos Correios. Em pouco mais de meio século, o crescimento da carga postal transportada por aeronaves é vertiginoso: de mil e quinhentas toneladas em todo o ano de 1946 (SILVA, 1949), passa a 5,5 mil em 1977, depois para 66 mil em 1988 (GERTEL, 1991), até atingir hoje a marca de 650 toneladas por dia, ou seja, mais de 200 mil toneladas anualmente. Ainda assim, no modal de superfície são transportadas diariamente oito vezes mais, somando 5 mil toneladas diárias de carga postal, perfazendo todos os dias 390 mil quilômetros de distância percorrida por caminhões e embarcações ${ }^{149}$. Desta maneira, a criação das redes RPN e LTN, juntamente com a reorganização das estruturas de distribuição intraurbana, todas da década de 1970, estão na base da implantação dos serviços expressos que ocorreu na década seguinte ${ }^{150}$.

É notável também o deslocamento do centro da rede aérea, com perda relativa de importância do Rio de Janeiro para São Paulo como principal ponto de articulação. Com a construção de Brasília e a escolha dos Correios por operar um terminal de cargas em seu aeroporto, a rede se apresenta hoje menos centralizada na Região Sudeste do que fora em meados do século passado. O terminal de cargas do aeroporto de Salvador completa um quadrilátero de conexões na porção centro-leste do Brasil, ao mesmo tempo em que permite agilizar as correspondências de âmbito regional no Nordeste.

Duas lógicas complementares regem a topologia da rede aérea dos Correios. Em primeiro lugar, verifica-se o papel do Estado e a permanência de um projeto de integração

\footnotetext{
${ }^{149}$ Dados adquiridos em trabalho de campo no CTE Jaguaré, São Paulo-SP, em março de 2015.

${ }^{150}$ Conforme informações coletadas no Museu dos Correios, em trabalho de campo realizado em março de 2016.
} 
territorial que direcionou as ações do correio durante boa parte do século XX. Com exceção de João Pessoa ${ }^{151}$, a RPN toca diariamente em todas as capitais do país, sem distinção, mesmo naqueles lugares onde o volume de encomendas não é significativo. Esse dado é importante porque aponta para o caráter político da rede, com a escolha dos Correios em manter no mínimo um ponto com conexão rápida em todos os estados da federação. Conforme asseverado pelo historiador Romulo Valle, chefe do Departamento de Gestão Cultural e do Museu dos Correios,

os Correios são a única empresa de entrega que atua mesmo naqueles pontos do país onde a operação não é economicamente viável, o que os tornam um importante fator de integração nacional, bem como de indução de desenvolvimento e acesso a facilidades que não seriam possíveis apenas por meio das operações privadas. ${ }^{152}$

Aliado às unidades estaduais de tratamento de carga que também estão nas capitais, como desdobramento têm-se o reforço a essas cidades como centros de gestão do território (CORRÊA, 2007), pelo controle que detêm sobre os fluxos postais que entram e saem de seus respectivos estados. Essa função outorgada às capitais é ainda mais relevante quanto mais se verifica a recente perda de seu poder de gestão e a centralização do comando em metrópoles como São Paulo, o que corrobora para o acirramento das desigualdades regionais ${ }^{153}$.

Mas também há lógicas amparadas em princípios de mercado. Além das capitais, apenas oito cidades do país estão integradas na rede aérea dos Correios, o que as distingue do restante do território quanto à velocidade dos fluxos. A escolha dessas cidades não tem que ver com a distância da capital do estado ou com a inexistência de outros modais de transporte, como acontecia com o CAN na década de 1940. Seus aeroportos são utilizados pelos Correios como pontos de entrada e saída de carga em regiões com grande relevância econômica no país, cujo volume de objetos SEDEX torna rentável o empreendimento. Evidentemente, nessas regiões há um maior consumo de serviços postais, principalmente os expressos, pelos diversos agentes aí instalados, como empresas, órgãos estatais e a população em geral. Todas elas são cidades médias de destaque na rede urbana brasileira, sendo que metade desses centros está localizada no estado de São Paulo: são as cidades de Ribeirão Preto, São José do Rio Preto, Bauru e Presidente Prudente. Como desdobramento da própria rede de cidades

\footnotetext{
${ }^{151}$ No Brasil, as cidades de João Pessoa e Recife são as duas capitais mais próximas, distando cerca de 120 quilômetros. Por isso, o transporte rodoviário consegue cumprir as exigências de prazos de entrega e de demandas para a Paraíba, que utiliza o Aeroporto de Guararapes, em Pernambuco, para a saída e entrada de cargas expressas.

152 Entrevista realizada no Museu dos Correios, Brasília-DF, em março de 2016.

${ }^{153}$ As privatizações dos serviços e empresas públicas levaram as capitais a diminuir seu poder como centros de gestão do território, ocasionando maior centralização nacional do comando em metrópoles como São Paulo. Sobre o papel que desempenhavam as capitais por meio dos extintos bancos estaduais, vide Corrêa (2006).
} 
paulista, as cidades de Uberlândia, na região do Triângulo Mineiro, e Londrina, no norte do Paraná, também são servidas pelo modal aéreo. Assim, revela-se o peso da Região Concentrada ${ }^{154}$ na divisão territorial do trabalho, reproduzindo uma tendência verificada para o Correio do início do século XX de constituição de uma área core. Nas demais regiões brasileiras, as únicas cidades não capitais servidas pelo modal aéreo são Petrolina-PE, na área de agricultura irrigada do Vale do São Francisco; e Barreiras-BA, no centro da área de produção de commodities agrícolas (especialmente soja e algodão) do cerrado nordestino.

Nesse sentido, haveria que reconhecer dois valores distintos para os lugares, conforme apontado por M. L. Silveira (2002). Há aqueles lugares acionados pelo seu "valor capitalístico", que para o correio corresponderiam aos pontos interligados com maior rapidez nessas regiões modernizadas. Já o "valor político" dos lugares se expressa na opção de integrar indistintamente as capitais político-administrativas na rede postal aérea.

Para os próximos anos, a RPN deve sofrer uma mudança substancial. Os Correios anunciaram que será inaugurado no prazo de dois anos e meio um grande hub logístico para cargas expressas no aeroporto de Viracopos, em Campinas-SP ${ }^{155}$. Conforme demonstrado por Camilo Pereira (2014), o volume de carga movimentado nesse aeroporto vem aumentando nos últimos anos, servindo como principal conexão de várias empresas, incluindo as multinacionais FedEx e UPS. Com esse novo fixo, a previsão é que os Correios realizem o processamento de um terço de toda a carga postal transportada pelo modal aéreo, que será levada por meio de 44 voos noturnos diários e mais 160 caminhões, estes utilizados principalmente para conectar a unidade operacional com a Região Metropolitana de São Paulo. Com o grande $h u b$, os Correios utilizarão uma estratégia logística que se assemelha àquela das empresas multinacionais, com a concentração das operações num ponto da rede.

O procedimento aqui apresentado diz respeito aos padrões adotados pelos Correios. Complementarmente, há estratégias diárias de logística na escala local, obrigando alguns ajustes na operação. Por exemplo, em caso de aeronave cheia, a carga pode seguir por caminhão para destinos não convencionais se houver possibilidade de cumprimento do prazo. Algumas dessas estratégias podem ser posteriormente padronizadas, o que demanda trabalhadores com alto grau de conhecimento especializado para coordenar as operações nos centros logísticos. No caso da Região Metropolitana de São Paulo, há alguns anos toda a

\footnotetext{
${ }^{154}$ Regionalização empregada por Santos e Silveira ([2001] 2011) para o Brasil, na qual a Região Concentrada corresponderia aos estados do Sudeste e do Sul.

${ }^{155}$ As informações foram divulgadas em abril de 2016 no site oficial dos Correios, por meio do endereço eletrônico https://www.correios.com.br/para-voce/noticias/correios-fecha-parceria-com-viracopos-para-criarhub-nacional-de-cargas-expressas.
} 
carga postal expressa destinada às regiões metropolitanas do Rio de Janeiro, Belo Horizonte e Curitiba deixou de seguir por aviões e passou a ser transportada pelo modal rodoviário (Fotografia 14).

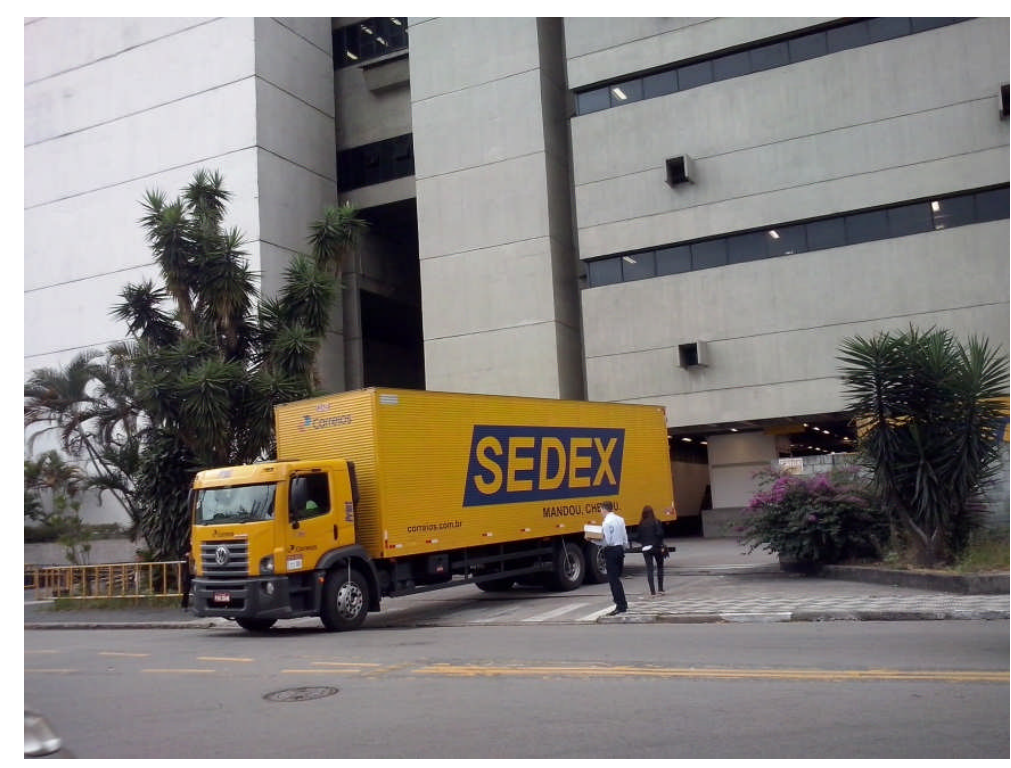

Fotografia 14 - Caminhão dos Correios deixando o CTE Jaguaré em São Paulo-SP com destino ao Rio de Janeiro-RJ.

Fonte: Trabalho de campo realizado em março de 2015.

Foto: Igor Venceslau.

Essa medida ocasionou mudança significativa no fluxo postal nacional, pois afeta diretamente a região de maior intensidade no tráfego de encomendas. Influenciaram na decisão fatores como a distância média entre essas cidades, que pode ser vencida em no máximo uma noite de viagem, aliado à disposição de infraestrutura rápida e segura de autopistas, além da maior flexibilidade e do menor custo do modal rodoviário.

\subsubsection{Os prazos de entrega: uma expressão do território desigual}

Tentar entender os prazos de entrega dos Correios pode, à primeira vista, parecer algo relegado ao passado. Não são poucos os equívocos nesse sentido, tendo o correio sido subestimado por autores como P. Virilio ao assumir que "em vez do prazo de dois ou três dias para a entrega dos formulários enviados pelo correio, hoje bastam quarenta e cinco segundos para que os pedidos de compra cheguem à sede da empresa" (VIRILIO, [1984] 2014, p.72). Pois bem, os pedidos chegam instantaneamente, mas de nada valem se as compras não chegarem depois, e essas não acompanham a velocidade dos fluxos informacionais. Como as compras chegam à empresa? E como chegam os produtos até a casa dos clientes, no caso do e-commerce, senão pelo mesmo correio que se reestruturou para entregar tanto mensagens quanto encomendas? 
Os modais de transporte utilizados na movimentação de carga dos Correios demonstram o constrangimento do território à atividade. As possibilidades de maior ou menor fluidez territorial irão determinar os diferentes prazos de entrega que a empresa oferece, com as respectivas defasagens com que os lugares são alcançados pelos fluxos materiais. Uma análise geográfica dos prazos de entrega revela a importância do território para o entendimento do correio brasileiro.

Para lidar com os 5570 municípios de origem e destino de correspondências, os Correios elaboraram uma tipologia de cidades para o Brasil que as divide em quinze grupos com prazos distintos, identificados por letras. Assim, as cidades do tipo "A" são aquelas onde o prazo mínimo para as correspondências é de 1 dia útil após a postagem; nas cidades do tipo "B" a correspondência será entregue em, no mínimo, 2 dias úteis após a postagem; para as cidades do tipo "C" o prazo é de 3 dias úteis; e assim sucessivamente. O caso extremo é o prazo para as cidades “O”, que é de 15 dias úteis após a postagem (Mapa 13). Esses valores são respectivos ao prazo mínimo para a entrega de objetos postais, correspondendo ao serviço expresso - SEDEX na escala nacional, sendo que o SEDEX local é entregue no dia seguinte à postagem. Os serviços não expressos são praticados com prazos maiores, variando de cinco dias úteis, na escala local, até mais de trinta dias na escala nacional, a depender da origem e do destino. Para a definição desses prazos, os Correios utilizam uma localidade-base de referência comum a todos eles, a cidade de São Paulo.

A lista de cidades A, com prazo de entrega de um dia útil, é ilustrativa dos pontos do território nacional dotados de maior fluidez (Anexo B). Do total de 160 municípios onde é possível garantir esse prazo rápido, 122 deles correspondem às capitais dos estados e suas respectivas regiões metropolitanas. Esse dado demonstra, por um lado, o caráter extremamente metropolitano e seletivo da fluidez territorial no Brasil e, por outro, o resultado da política dos Correios de incluir todas as capitais em sua rede de transporte aéreo de carga, independentemente da demanda de mercado. Assim, nos estados do Acre, Alagoas, Amazonas, Amapá, Maranhão, Piauí, Roraima, Rondônia e Tocantins, todos eles das regiões Norte e Nordeste, a maioria com desenvolvimento econômico menos expressivo no conjunto da federação, a máxima fluidez alcança somente o município da capital. Em estados como Pernambuco, Rio Grande do Norte, Ceará, Goiás, Espírito Santo, entre outros, municípios da região metropolitana da capital, como Olinda-PE e Vila Velha-ES também estão incluídos nas áreas de prazo mais rápido. Como tendência geral, há o reforço às mesmas regiões que ofereciam as melhores condições para a difusão dos serviços postais no passado, demonstrando a relevância da formação socioespacial. 


\section{Brasil: Prazos de entrega dos Correios, 2016}

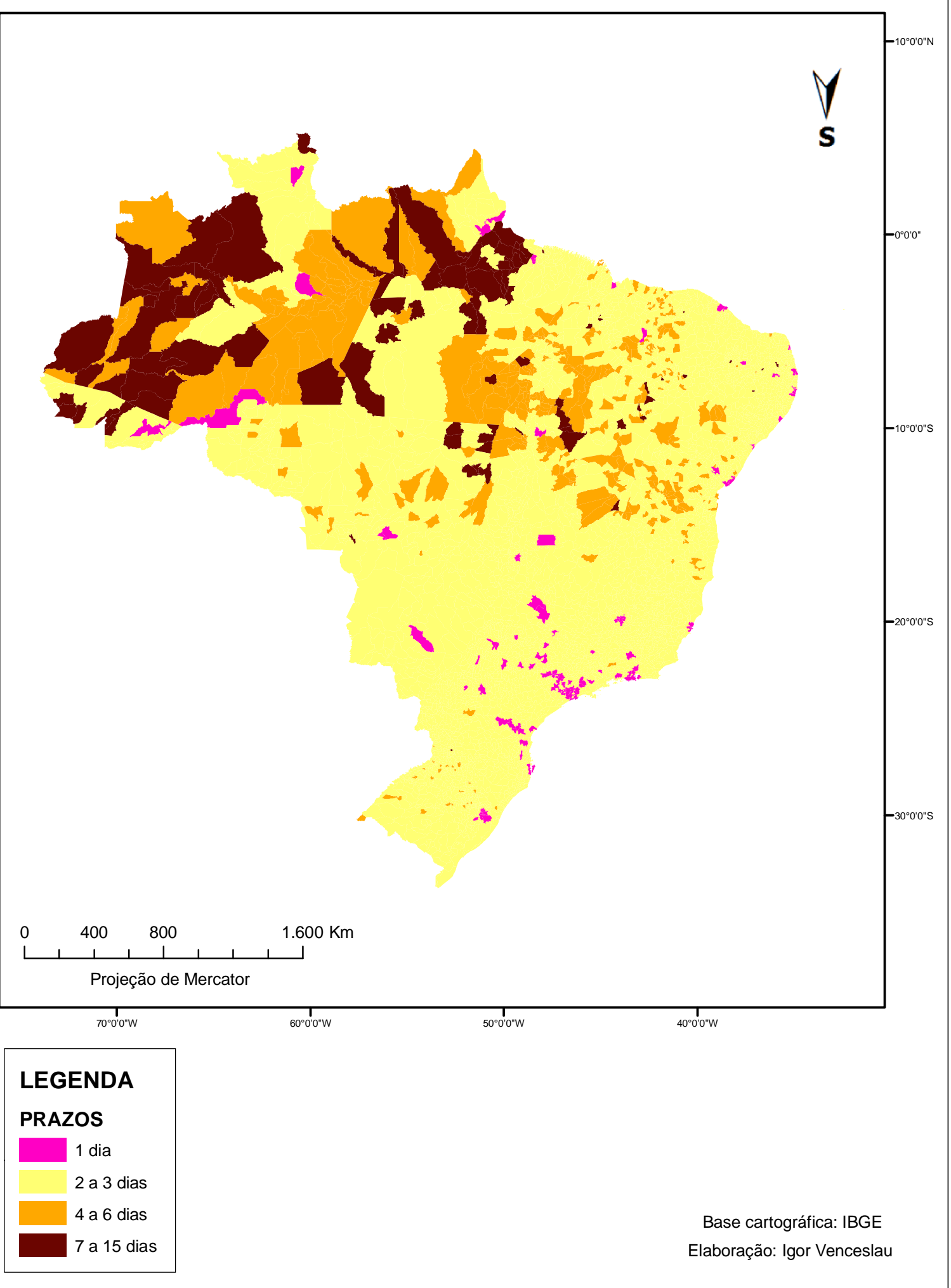

Mapa 13 - Brasil: prazos de entrega dos Correios, 2016. Localidade-base de referência oficial para o cálculo: cidade de São Paulo. Serviço postal de referência: SEDEX.

Fonte: Elaboração própria a partir de dados do DENAF/Correios e do Simulador de Prazos e Preços. 
Fora das capitais e suas respectivas regiões metropolitanas, as pontos atingidos por fluxos de maior velocidade são bastante seletivos. Apenas seis estados oferecem condições de fluidez que permitem a entrega no dia seguinte em cidades do interior. Ainda assim, na Bahia e no Rio de Janeiro esses pontos correspondem somente às cidades de Feira de Santana e Petrópolis, respectivamente, cuja localização é relativamente próxima à capital. O mesmo ocorre em Santa Catarina, onde somente em Blumenau e Joinville a entrega pode ser realizada no dia seguinte a partir de vários destinos no Brasil. Os estados do Paraná e Minas Gerais apresentam condições de fluidez para cidades mais distantes do núcleo metropolitano, o que também corresponde à topologia da rede de transporte aéreo: no primeiro caso, são as cidades de Paranaguá, Ponta Grossa, Londrina e Maringá; no segundo, a lista contém Juiz de Fora, Varginha, Uberaba e Uberlândia.

Somente no estado de São Paulo é possível encontrar as condições de fluidez territorial que permitem aos fluxos postais alcançarem diferentes lugares com a mesma velocidade. Excluídas as capitais estaduais e suas regiões metropolitanas, três em cada quatro municípios brasileiros onde a entrega dos Correios é realizada no dia seguinte à postagem estão localizados no estado de São Paulo. Além do peso que possuem no conjunto da economia brasileira, essas cidades são dotadas de infraestruturas - aeroportos, rodovias expressas - que garantem entregas no prazo mais rápido. Além das cidades já contempladas na rede da RPN, somam-se Araraquara, Araçatuba, Campinas, Franca, Birigui, Sorocaba, Santos, Taubaté, Marília, Itu e muitas outras.

No entanto, o prazo aqui demonstrado é aquele considerado padrão, ou seja, tendo como local de postagem a cidade de São Paulo. Se complexificarmos um pouco mais, considerando os prazos médios de entrega de encomendas expressas entre todos os estados brasileiros, teremos um retrato da desigual articulação desses lugares com os demais (Quadro 9). Há mais fluidez nos estados das regiões Sul e Sudeste, onde os Correios conseguem entregar no dia seguinte as encomendas originadas em praticamente todo o território nacional. Nas regiões Centro-Oeste e Nordeste, há estados para os quais os fluxos são mais velozes, de maneira generalizada, e outros onde os prazos médios com origem na maioria dos demais estados passam a ser de dois ou mais dias úteis. Na região Norte os prazos são os mais longos, sendo que as trocas mais lentas, de três dias úteis, prevalecem entre os estados dessa região e os da região Nordeste. 


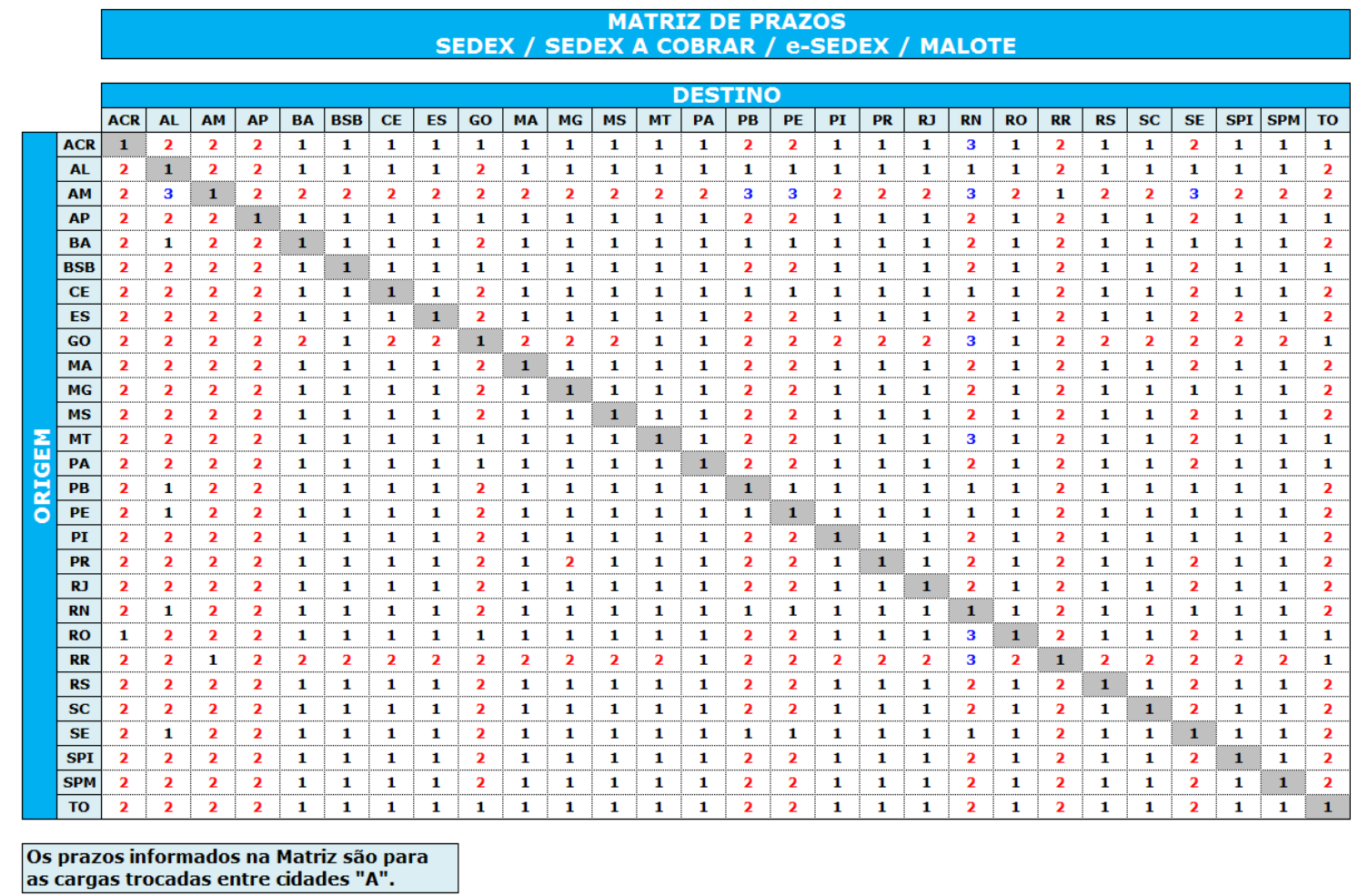

Quadro 9 - Matriz de prazos de entrega de serviços expressos dos Correios em dias por Diretoria Regional ${ }^{156}$, 2016. Fonte: Vice-Presidência de Encomendas dos Correios.

As áreas de maior viscosidade no território brasileiro, ou seja, aquelas áreas dotadas de menores condições de fluidez e consequentemente onde os prazos de entrega são os mais lentos, são formadas por municípios da região Norte, em sua maioria, e alguns da região Nordeste e do Mato Grosso (Anexo C). Em cidades como São José do Xingu-MT ou Barcelos-AM, as encomendas SEDEX somente chegam às mãos do destinatário a partir do sétimo dia útil, considerando as condições normais para a entrega. Em Boca do Acre-AM ou São Félix do Tocantins-TO, os prazos ultrapassam os dez dias, para postagens a partir de São Paulo. Os casos extremos são os registrados para municípios como Chaves-PA ou Santa Rosa do Purus-AC, para onde a entrega rápida só chega com quatorze ou quinze dias úteis depois da postagem.

A defasagem nos prazos dos Correios parece sugerir a necessidade de relativizar o conceito de "compressão do tempo-espaço". Ao menos para o correio, esse "encolhimento do mapa do mundo graças a inovações nos transportes que aniquilam o espaço por meio do tempo" (HARVEY, [1989] 2011, p.220) depende do lugar onde se está, pois concomitantemente ao aumento da velocidade dos fluxos, multiplica-se a distância entre o

\footnotetext{
${ }^{156}$ As diretorias regionais dos Correios correspondem praticamente a cada um dos estados brasileiros. São Paulo é o único estado que possui duas diretorias, uma para o região metropolitana (SPM) e outra para o interior (SPI). Os dados referentes ao Distrito Federal aparecem no quadro com a sigla correspondente BSB.
} 
prazo mais rápido e o mais lento no território. Essa viscosidade, a outra face da fluidez territorial, contrasta profundamente com a noção de "expresso". O tempo da velocidade e da rapidez convive num mesmo território com o tempo da lentidão das pequenas cidades e vilarejos do interior do país. Desta maneira, pode-se compreender o "expresso" como o tempo das metrópoles, em contraposição às múltiplas temporalidades encontradas hoje no território. Não é esse mesmo o tempo das empresas multinacionais de correio, por meio do qual não se inclui todo o espaço, mas apenas alguns pontos? O próprio slogan "mandou, chegou" do serviço SEDEX carece de sentido real em boa parte do Brasil, diante da diversidade dos meios geográficos e dos ritmos de circulação proporcionados em cada um deles. Dentro dos Correios, o SEDEX passa atualmente por uma discussão sobre excluir ou não o serviço nas cidades de prazos superiores a 10 dias, por questões de estratégia de mercado ${ }^{157}$. Nesses lugares seria oferecido outro serviço, que perderia o epíteto expresso.

Apesar de todas as cidades brasileiras contarem com a entrega domiciliar dos Correios ${ }^{158}$, há algumas áreas que não dispõem do serviço de entrega. São bairros sem a regularização dos logradouros pela prefeitura municipal, onde o destinatário deve buscar seu objeto na própria unidade de distribuição. Esse procedimento também é adotado no caso de áreas de urbanização dispersa, a exemplo de loteamentos localizados ao longo de rodovias. Para além dessas questões de cunho mais técnico, há impossibilidade de entrega atrelada a causas políticas. São as chamas “áreas de risco”, geralmente correspondendo a favelas.

Outras vezes a entrega é interrompida por medidas contingenciais. O exemplo mais recente foi a suspensão de todos os serviços com prazos determinados (SEDEX e similares) e da entrega domiciliar nos principais logradouros da área central e de alguns bairros da cidade do Rio de Janeiro por aproximadamente dois meses, durante os Jogos Olímpicos de 2016. A restrição por decreto municipal proibiu a circulação de veículos de carga, alterando a logística da empresa nessas áreas ${ }^{159}$. Já os serviços não expressos passaram a contar com acréscimos nos prazos de entrega para a capital fluminense.

As desiguais condições de circulação no território brasileiro são desafios à logística dos Correios, que acaba internalizando-as sob a forma de diferentes prazos de entrega. Nesse

\footnotetext{
${ }^{157}$ Informações adquiridas em trabalho de campo realizado na Vice-Presidência de Encomendas dos Correios, Brasília-DF, em março de 2016.

${ }^{158}$ Para se ter uma ideia da atualidade de um serviço de entrega domiciliar universalizado, mesmo no início da década de 1990 Gertel (1991) alertava para o fato de que a entrega domiciliar só ocorria para encomendas com menos de $1 \mathrm{~kg}$. Hoje a entrega acontece em todos os municípios, contando com veículos motorizados e carteiros a pé.

Segundo informações oficiais da empresa, disponíveis em https://www.correios.com.br/paravoce/noticias/correios-inicia-plano-especial-para-entregas-no-rio-de-janeiro.
} 
sentido, como falar em "dromologia", como o faz Virílio (1977), sem considerar que a rapidez alcançada pelos fluxos na atualidade é produtora, ao mesmo tempo, da lentidão? Os prazos são, portanto, uma expressão das desigualdades do território, sendo determinados pelo conjunto de sua materialidade e das condições técnicas e políticas que se impõem à circulação.

\subsection{O frenesi da velocidade e a diversificação dos serviços}

É pelo território que também pode ser compreendido o oferecimento desigual dos serviços dos Correios. Os serviços básicos, incluindo os não expressos e o SEDEX convencional, são oferecidos em todos os municípios do país, com diferentes prazos de entrega conforme já demonstrado. Para atender a demandas de fluxos mais velozes, os Correios criaram serviços com prazos contados em horas a partir do horário de postagem, que são variações do serviço SEDEX convencional. Esses serviços mais rápidos só podem ser oferecidos naqueles pontos do território que dispõem das condições de fluidez exigidas por seus prazos just in time. A constante diversificação da carteira de serviços postais por meio da criação de modalidades mais rápidas indica um frenesi da velocidade nas ações do correio.

\subsubsection{Os serviços expressos e os espaços da rapidez}

O serviço denominado SEDEX 10 foi lançado em 2001, emblemático de um novo século para o correio brasileiro. O objetivo de sua criação foi permitir conexões rápidas entre as principais cidades do país, com operações logísticas noturnas e a garantia de entrega no destino até às dez horas da manhã do dia útil seguinte à postagem. Com a possibilidade de acelerar ainda mais os fluxos postais, os Correios passaram a oferecer, desde 2004, um serviço de entrega no mesmo dia da postagem, o SEDEX Hoje, cuja logística exige estratégias bastante diferenciadas dos demais serviços postais. O SEDEX Hoje tem o tratamento mais prioritário dos Correios, sendo transportado em veículo próprio diretamente das agências e centros de entrega para os terminais de carga dos aeroportos, sem passar pela intermediação dos centros de tratamento de encomendas.

Os serviços expressos são uma manifestação, no correio, da aceleração contemporânea (SANTOS, 1994). Sua criação é correspondente à aceleração na transmissão de informações e à aceleração do tempo de circulação dos objetos, como mercadorias, e do capital. E, se 
historicamente a difusão do correio acompanhou a própria urbanização no território brasileiro (Capítulo 1), os serviços mais expressos vêm acompanhando a metropolização do espaço.

Mas nem sempre as inovações correspondem a acréscimos de velocidade. Em 2013, pela impossibilidade de cumprimento dos prazos de entrega do SEDEX 10 em algumas localidades, os Correios lançaram no mercado o serviço de SEDEX 12, com horário de entrega até às $12 \mathrm{~h}$ do dia seguinte à postagem. Esse serviço foi criado inicialmente para atender a cidade de Salvador, cujo conjunto de características locais foram determinantes para a escolha de uma nova estratégia: ausência de automação no Centro de Tratamento de Encomendas de Salvador, com triagem manual; distância do aeroporto até o centro da cidade $^{160}$; a geomorfologia local ${ }^{161}$; condições de trânsito e mobilidade intraurbana. Esses fatores levavam à perda dos prazos e consequentemente o pagamento de diversas multas pelos Correios aos clientes ${ }^{162}$. De fato, é o conjunto das condições do lugar (Salvador) que exige uma logística diferenciada, pois só ali todos esses fatores se combinarão dessa maneira. $\mathrm{O}$ mesmo sendo válido para todos os demais lugares, revelando a importância do território para o entendimento e realização da logística, desde elementos como o sítio urbano até os seus conteúdos técnicos e normativos. Desde então, o serviço SEDEX 12 tem sido oferecido a outros destinos como uma alternativa de horário mais flexível.

Tomamos emprestado de Santos e Silveira ([2001] 2011) a noção de espaços da rapidez e espaços da lentidão. Os lugares no Brasil que dispõem dos serviços SEDEX 10, SEDEX 12 e SEDEX Hoje conformam um espaço da rapidez, que se articula em rede. A análise desses serviços se torna bastante complexa, já que para cada cidade ou grupo de cidades corresponde uma lista respectiva de destinos. Esse nível de análise exigiria estudos de caso nas escalas local e regional, semelhante ao já realizado anteriormente para o sul baiano (VENCESLAU, 2012). Tomemos como exemplos os estados do Rio Grande do Norte e Santa Catarina. No primeiro caso (Anexo D), mais simples, predominam apenas dois movimentos principais. Um movimento interno permite que as correspondências de dezenas de cidades potiguares de todos os portes sejam entregues na capital, Natal, até às 10 horas do dia seguinte. Um segundo movimento conecta o Rio Grande do Norte com as principais cidades

\footnotetext{
${ }^{160}$ O Aeroporto Internacional Luís Eduardo Magalhães está localizado no município metropolitano de Lauro de Freitas e dista cerca de $25 \mathrm{~km}$ do centro de Salvador.

${ }^{161}$ Salvador tem uma geomorfologia peculiar, que faz com que a cidade seja dividida em Cidade Alta e Cidade Baixa. Entre as duas zonas, várias ladeiras e vielas ditam outro ritmo ao trânsito na escala intraurbana.

${ }^{162}$ Serviços expressos possuem um seguro automático que pode ser reclamado pelo cliente em caso de atraso ou extravio do objeto, correspondendo ao valor mínimo atual de R $\$ 250,00$ por encomenda SEDEX.
} 
das regiões Sudeste, Sul e Centro-Oeste do país, além de Salvador (no Nordeste), mas somente às cidades da Região Metropolitana de Natal está reservada essa velocidade.

O caso de Santa Catarina é mais complexo que o anterior (Anexo E). Ali há uma variedade de conexões rápidas em todas as escalas articulando as pequenas cidades à capital Florianópolis, a Joinville, a Blumenau e às regiões metropolitanas de Porto alegre e Curitiba. É possível que encomendas expressas enviadas de cidades médias como Chapecó sejam entregues na manhã seguinte em outras cidades médias da região Sul, como Santa Maria ou Pelotas no Rio Grande do Sul. Há um corredor litorâneo de cidades que vai desde Joinville até Criciúma, passando por Blumenau e Itajaí e incluindo, além da capital do estado, uma variedade de cidades de diversos tamanhos, de onde e possível enviar SEDEX 10 para os principais destinos do país, como São Paulo, Brasília, Salvador, mas também cidades do interior de São Paulo e Minas Gerais, entre outras. No caso de cidades localizadas na divisa com outros estados, como Porto União, o serviço permite conectá-la também com o estado vizinho, neste caso alcançando com velocidade Londrina ou São José dos Pinhais-PR.

Embora não haja condições de analisar aqui todos os lugares onde os serviços SEDEX 10, 12 e Hoje são oferecidos, nacionalmente a tendência tem sido de maior velocidade nas ligações com a capital do respectivo estado e, fora dele, com o estado de São Paulo, seguido em menor intensidade pelas regiões metropolitanas do Rio de Janeiro, Belo Horizonte, Porto Alegre e Curitiba, além de Brasília. Afirma-se, assim, a predominância das conexões rápidas com a Região Concentrada e, dentro dela e em maior intensidade, com São Paulo, não se limitando à capital, mas se estendendo por sua região metropolitana e pelo interior do estado. Essa rapidez só tornou-se possível porque a estratégia logística dos serviços mais expressos integra o território brasileiro por meio de uma "circulação superior", para empregar um termo de Silva (1949), enquanto os demais serviços se valem de outros tipos de circulação.

\subsubsection{Os serviços não expressos e os espaços da lentidão}

Contrastando com os espaços da rapidez dos serviços expressos, há o que poderíamos adjetivar de espaços da lentidão no correio, onde predominam os serviços não expressos. Não se trata de separar o "espaço dos fluxos" do "espaço dos lugares"163, como propôs Castells (1999), pois os fluxos não se realizam sem os lugares e estes são, por sua vez, conectados e animados pelos fluxos. No correio brasileiro, os serviços não expressos estão disponíveis em

\footnotetext{
${ }^{163}$ Para o autor, o "espaço dos lugares" seria o espaço de contiguidade; já o "espaço dos fluxos" seria o "suporte material de práticas sociais simultâneas comunicadas à distância" (CASTELLS, 1999, prefácio, p.173).
} 
todas as cidades, ao contrário do SEDEX 10, SEDEX 12 e SEDEX Hoje que são seletivos. Assim, os mesmos lugares onde a velocidade dos fluxos expressos permite conexões mais rápidas possuem outras maneiras de articulação por meio de serviços mais lentos. Logo, o que seriam os espaços da lentidão no correio brasileiro? Eles seriam justamente aqueles onde os serviços mais rápidos não alcançam, relegando-os a uma situação periférica no conjunto do território nacional.

Mais baratos, os objetos postais do tipo não expressos utilizam modais de transporte de superfície e não possuem rastreamento em todos os pontos por onde passam. Geralmente, junto com o SEDEX convencional, são os únicos serviços postais disponíveis nas pequenas cidades, especialmente as mais distantes dos centros intermediários; as cidades desprovidas dos sistemas técnicos privilegiados pela logística postal, como as localidades ribeirinhas da Amazônia, que recebem a carga postal via rede de transporte fluvial; e cidades limítrofes localizadas em diferentes unidades da federação. Exemplifiquemos este último caso: uma correspondência que sai da cidade Mucuri-BA e se destina a Pedro Canário-ES, distantes cerca de $40 \mathrm{~km}$, pode demorar cinco dias úteis, com o serviço expresso, e dez dias úteis num serviço não expresso. A correspondência postada em Mucuri seguirá até o centro de tratamento regional, localizado na cidade de Teixeira de Freitas-BA. De lá, seguirá por superfície (rodovia) até o centro de tratamento na cidade de Feira de Santana numa viagem de quase 800 quilômetros. Da Bahia ela seguirá em outro caminhão até o centro de tratamento Benfica, no Rio de Janeiro. De lá, será encaminhada em outro veículo até Vitória para o centro de tratamento estadual capixaba. A partir daí, será transportada primeiramente até o centro regional em São Mateus-ES e, enfim, para o destino final, a pequena cidade de Pedro Canário-ES.

Esses lugares aonde as correspondências chegam com prazos maiores são também onde a divisão territorial do trabalho é menos intensa, ou onde as funções que exercem, no conjunto do território nacional, são menos privilegiadas ou mais banais. As conexões mais rápidas são aquelas que ligam esses espaços da lentidão a alguns pontos que possuem papel de comando na divisão territorial do trabalho nacional. É assim que a única cidade que figura na lista de destinos expressos em todo o país é São Paulo; nem mesmo Brasília ou o Rio de Janeiro estão disponíveis como destino para encomendas mais urgentes da Amazônia ao pampa gaúcho. Esta seria outra característica desses espaços de lentidão: sua articulação muito mais rápida com São Paulo do que com outras cidades do mesmo estado ou região. Ali onde o território é pouco fluido, principalmente pela ausência de sistemas técnicos que permitam uma maior rapidez nos transportes, a temporalidade das entregas distorce o mapa do 
Brasil para uma outra configuração: a topologia obrigaria a pensar um Brasil onde São Paulo estivesse no centro; depois, as outras metrópoles, capitais estaduais e algumas cidades médias; nas "bordas do território" apareceriam as pequenas cidades e todos os demais espaços marcados pela lentidão.

Na atualidade, a variável distância não perde importância, embora mude de qualidade com as novas tecnologias. Hoje é possível a duas cartas viajarem no mesmo espaço em tempos (ou temporalidades) diferentes; mas a distância ainda está lá. Conforme demonstrado, a distância é uma variável-chave na logística dos Correios, influenciando na decisão da escolha do modal de transporte; na substituição do avião pelo caminhão entre São Paulo e Rio de Janeiro, mas não para Goiânia; justificando o fato de Campinas ou João Pessoa não serem conectadas na rede de transporte aéreo, pois a proximidade com as metrópoles permite compartilhar o mesmo aeroporto; no SEDEX 10 que chega em Petrópolis, Feira de Santana e Campina Grande. Assim, não temos assistido ao desaparecimento da "distância-espaço" e ao pretenso desaparecimento da "distância-tempo", conforme apregoado por Virílio ([1984] 2014). Na prática, em se tratando de logística dos Correios, Rio Branco é tão próximo de São Paulo quanto Campinas; já Xapuri, no mesmo estado do Acre, é tão distante de São Paulo quanto de Rio Branco, mas para ambas a técnica antes relativiza do que suprime as distâncias.

$\mathrm{O}$ oferecimento desigual dos serviços mais rápidos revela a própria desigualdade socioespacial. Os prazos e a distribuição dos serviços postais dos Correios são uma expressão da divisão territorial do trabalho no Brasil, na medida em que destacam os lugares com maiores ou menores condições de fluidez, característica essencial para a escolha da localização das atividades engendradas pelos diferentes agentes sociais. 
CORREIOS, REDE URBANA E DIVISÃO TERRITORIAL DO TRABALHO NO BRASIL 
La circulation est à la base de toute géographie

et de toute politique

Jean Gottmann, La politique des États et leur géographie ${ }^{164}$

O correio pode ser considerado, ao mesmo tempo, como expressão e elemento constitutivo da divisão territorial do trabalho no Brasil. Como expressão, as ações dos Correios sofrem os constrangimentos da divisão do trabalho vigente e das pretéritas, de tal modo que o serviço postal não pode ser indiferente ao território que ele integra. Como parte de uma divisão do trabalho, os Correios acabam por reforçar desigualdades e assimetrias regionais já estabelecidas. E como a localização das agências, unidades operacionais e a maior parte das ações dos Correios se dão nas cidades, a rede urbana comparece como um elemento do território que permite uma aproximação empírica da divisão territorial do trabalho.

Nesta análise, estão sendo considerados os elementos fixos e fluxos do espaço. As coisas fixas, aí incluídas as infraestruturas e os objetos criados, e os fluxos que são gerados por esses fixos, ou seja, as coisas em movimento, constituem uma totalidade necessária à circulação (SANTOS, [1988] 2012a). Desta maneira, seria possível distinguir os fixos geográficos criados para permitir a circulação no correio, desde uma simples agência de bairro até aquelas unidades especializadas, que cumprem funções mais complexas. Neste trabalho, estamos adjetivando esses fixos geográficos produzidos e usados pelo correio como fixos $_{\text {postais }}{ }^{165}$, dado a sua quantidade e diversidade no território. Do mesmo modo, ao movimento das cartas, encomendas e todos os demais objetos do correio, sempre gerados desde um fixo postal, chamaremos de fluxo postal.

No Brasil, há profundas desigualdades regionais quanto à distribuição dos fixos geográficos e à origem, intensidade e qualidade dos fluxos. Extensamente demonstrada por Santos e Silveira ([2001] 2011), essa desigual distribuição se torna uma diferenciação regional que possibilita falar em quatro regiões distintas no país: a Região Nordeste, que corresponde

\footnotetext{
${ }^{164}$ Gottmann, 1952, p.120. "A circulação está na base de toda geografia e de toda política” (Tradução nossa).

${ }^{165}$ Essa adjetivação tem o intuito qualitativo, não desmerecendo nem empobrecendo a noção de fixo geográfico. É possível encontrar esse recurso de adjetivação em outras pesquisas: o próprio autor empregou "fixo público", "fixo privado" e "fixo social" (SANTOS, [1987] 2007); Contel (2006) fala em "fixo geográfico financeiro" e "fixo geográfico bancário"; os trabalhos de Braga e Castillo (2013) e Huertas (2013) tratam de "fixos logísticos".
} 
aos nove estados da mesma regionalização elaborada pelo Instituto Brasileiro de Geografia e Estatística (IBGE) ${ }^{166}$; a Região da Amazônia, formada pelos estados do Norte, com exceção do Tocantins; a Região Centro-Oeste, que além dos estados que o IBGE também inclui sob essa nomenclatura conta com o Tocantins; e a Região Concentrada, composta pelos estados do Sudeste e Sul. Os quatro Brasis, como falam os autores, devem ser entendido à luz dos meios geográficos, sua coexistência e desigual manifestação no país. Assim, a Região Concentrada conheceu uma maior difusão do meio técnico-científico-informacional, que nesse subespaço se implantou como uma mancha mais ou menos homogênea, olhando numa escala nacional. Nas demais regiões, as modernizações são mais seletivas e o meio técnicocientífico-informacional se instalou em apenas alguns pontos.

Essas manchas e pontos mais modernos se articulam nacional e mundialmente em rede. Para Musso (2004, p.31), uma rede ${ }^{167}$ pode ser entendida como "uma estrutura de interconexão instável, composta de elementos em interação, e cuja variabilidade obedece a alguma regra de funcionamento". Daí, a depender dos elementos considerados numa rede, admite-se falar em rede biológica ${ }^{168}$, rede social $^{169}$, rede técnica ${ }^{170}$, entre outras. A rede geográfica seria um tipo específico de rede, formada por um conjunto de localizações sobre a superfície terrestre articulado por fluxos e caminhos. Em concordância com (CORRÊA, 1999, p.65-66), a rede passa a ser geográfica quando "seus fluxos internos e externos articulam lugares concretos com papéis definidos na rede".

Rede e território não são excludentes, pois não há forma reticular fora do espaço geográfico. A rede é tomada aqui como elemento constitutivo do território e seu papel fundamental para a ação de agentes diversos (RAFFESTIN, 1993; SANTOS, [1996] 2012b; HAESBAERT, 2011). A rede permite a integração do território, por um lado, mas também produz uma seletividade ao conectar alguns pontos e não outros; ou, ao conectar a todos, fazêlo desigualmente.

O que em Geografia se convencionou chamar de rede urbana, ou rede de cidades, é a rede geográfica por excelência. Ela contém e está contida nos outros tipos de redes que

\footnotetext{
166 Regionalização brasileira vigente elaborada pelo IBGE, que considera as cinco macrorregiões: Norte, Nordeste, Centro-Oeste, Sudeste e Sul.

${ }^{167}$ O termo rede foi inicialmente empregado para designar partes do corpo humano, como a rede de circulação sanguínea e a rede nervosa. A partir do século XIX, ele passa a designar o próprio território: "O nascimento do conceito moderno de rede, enquanto ele permite conceber e realizar uma estrutura de gestão do espaço e do tempo, é contemporânea à obra de Claude-Henri de Saint-Simon (1760-1825). A rede sai do corpo e torna-se um artefato superposto a um território e anamorfoseando-o" (MUSSO, 2004, p.22).

${ }^{168}$ Capra (1998).

${ }^{169}$ Sobre redes sociais, consulte-se Scherer-Warren (1999).

${ }^{170}$ Musso (2004).
} 
possamos adjetivar (técnicas, empresariais, de solidariedade, de transporte, telecomunicações, etc.): "a rede urbana é a expressão mais complexa de todos os tipos de redes" (SPOSITO, 2008, p.69). Essa ideia também é compartilhada por Corrêa (1999, p.69), para quem este tipo de rede é complexo por ser a "principal síntese das redes geográficas", sendo ela mesma uma rede geográfica que assume diversas formas e conteúdos. Isto se dá porque toda cidade, não importando o seu tamanho, função, idade, localização ou qualquer outro atributo, se encontra articulada no interior de uma rede, a rede urbana (SOUZA, 2007). Não somente entre si, diria Eliseu Sposito (2008), mas também internamente as cidades se estruturam em forma de rede. Podemos admitir, com Moreira (2012, p.171), que é a cidade o "ponto de referência de uma gama de conexões que recobre e vai deitar-se sobre o espaço terrestre como um todo numa única rede".

Como a tipologia e a topologia dos fixos e fluxos postais se relacionam com a rede urbana e a divisão territorial do trabalho no Brasil? Qual é o peso da Região Concentrada para o correio nacional? Qual é o papel desempenhado por São Paulo na logística dos Correios? De que maneira a topologia dos Correios se confunde com a própria rede urbana brasileira? Essas e outras questões orientam a discussão que será apresentada neste capítulo, cujo objetivo é revelar a relação entre tipologia e topologia dos fixos e fluxos postais com a divisão territorial do trabalho e a rede urbana brasileira, evidenciando o papel de São Paulo e da Região Concentrada.

\subsection{Aspectos da rede urbana brasileira no início do século XXI}

Numa definição inicial, Corrêa (2006, p.16) entende por rede urbana “o conjunto de centros funcionalmente articulados entre si”, para em seguida acrescentar que esta forma espacial é uma "expressão fenomênica particular de processos sociais que se realizam em um amplo território envolvendo mediações diversas que se verificam nas cidades" (CORRÊA, 2006, p.37). Apesar de ter ganhado fôlego na segunda metade do século XX, as preocupações com a rede urbana não são tão recentes na Geografia. Ela está presente já em 1933 na Teoria das Localidades Centrais do alemão Walter Christaller, muito utilizada pelos geógrafos até os dias atuais ${ }^{171}$. Foi o geógrafo Michel Rochefort, contudo, quem sistematizou o conceito de rede urbana e iniciou estudos mais acurados na França e depois em outras partes do mundo, inclusive no Brasil. Para o autor, pode-se considerar como rede urbana

\footnotetext{
${ }^{171}$ Por exemplo, no estudo Regiões de Influência das Cidades (REGIC), elaborado periodicamente pelo Instituto Brasileiro de Geografia e Estatística, em sua última versão de 2007 (IBGE, 2008).
} 
a organização dos centros urbanos e de suas zonas de influência no interior de uma região controlada por um centro regional, e de arcabouço urbano a organização desses centros regionais no interior do espaço comandado pela capital nacional (ROCHEFORT, 1998, p.20)

A rede urbana também pode ser entendida como reflexo e condição para a divisão territorial do trabalho (CORRÊA, 2006, p.26). De acordo com Maria Encarnação Sposito (2005), a rede já manifestava uma divisão interurbana do trabalho na Europa dos séculos XIV ao XVII, que só foi possível por meio das ligações entre as cidades (como as estradas e as vias marítimas) e pelas ligações comerciais à época. A Revolução Industrial, por sua vez, marcou, de maneira definitiva, a constituição de redes urbanas, dada a crescente rede de relações que a atividade industrial evocava entre os lugares (fluxos de matérias-primas, pessoas, produtos, capitais, etc.). É assim que a produção, a circulação e o consumo só se realizam efetivamente por meio da rede urbana, articulando regiões distantes e estabelecendo uma economia mundial (CORRÊA, 2006, p.15). Rochefort (1998) acredita que somente no século XIX estamos autorizados a falar de uma rede urbana propriamente. A revolução nos transportes e comunicações, gestada inicialmente no bojo da própria Revolução Industrial, foi o suporte para o desenvolvimento da rede urbana e do próprio sistema capitalista a nível mundial, articulando desigualmente os centros urbanos, subordinando-os uns aos outros numa hierarquia (SPOSITO, 2005). Por meio da rede urbana é possível que o mundo seja, ao mesmo tempo, desigual e integrado (CORRÊA, 2006).

A rede urbana pode ser compreendida como o "meio através do qual produção, circulação e consumo se realizam efetivamente" (CORRÊA, 2006, p.15-16). Assim, falar em rede urbana não se limita à estrutura do território, a uma configuração estática que representa as articulações quase eternas das cidades num esquema hierárquico que impede outras relações. Rede urbana é, sobretudo, movimento e parte de um processo mais amplo de produção e circulação do valor excedente, de realização do capital. É assim que podem ser entendidos os movimentos de população, mercadorias, capitais e informação entre as cidades, bem como a sua desigual fixação em alguns centros.

Neste período histórico marcado pelo processo de globalização, duas seriam as consequências apontadas por Corrêa (2006) sobre a rede urbana brasileira: por um lado haveria a criação de novos centros, particularmente em áreas de expansão da ocupação, como na Amazônia; mas também estaria ocorrendo a refuncionalização dos centros já existentes, induzida inclusive pelas corporações globais. A refuncionalização é possível graças à fixidez presente nas formas da cidade e, de alguma maneira, da rede urbana. A rede de cidades pode, 
assim, revelar por meio de suas formas e padrões espaciais, elementos constitutivos da formação socioespacial de um dado território.

Milton Santos ([1988] 2012a) já chamava a atenção para um "curto-circuito" da rede urbana tradicional brasileira, onde a noção clássica de hierarquia (metrópole - cidade regional - centro local) é rompida e os diferentes níveis da rede urbana também podem se conectar diretamente (pequena cidade - metrópole, por exemplo). Para o autor, hoje "uma cidade pode não manter intercâmbio importante com uma vizinha imediata e, no entanto, manter relações intensas com outras muito distantes" (SANTOS, [1988] 2012a, p.55). Por conseguinte, o autor propõe uma nova noção da hierarquia urbana, fruto dos avanços nos transportes e comunicações e das novas redes de relações que se tecem no território.

Assim, a rede urbana brasileira conhece uma estruturação a partir de fluxos informacionais, recriando uma dialética entre concentração e dispersão no território (BERNARDES SILVA, 2001). No bojo desse processo, São Paulo se afirma como uma "metrópole onipresente" no território nacional, aliado às suas crescentes articulações externas (SANTOS, [1993] 2008b). Desta maneira, assiste-se a uma tendência à desconcentração das atividades produtivas, antes concentradas na metrópole, principalmente a indústria, e uma concomitante centralização do comando garantida por funções especializadas de serviços e fluxos informacionais comandados desde o espaço metropolitano.

Conforme se intensifica a circulação no território, as cidades médias também assumem novos papeis, conforme apontado por Sposito (2010). Na rede urbana, algumas cidades médias e pequenas se destacam pela centralidade interurbana que assumem, reposicionandoas no âmbito da divisão territorial do trabalho. Essa nova qualidade da rede urbana poderá ser verificada com maior intensidade quanto mais essas cidades estão inseridas na economia de mercado nacional e internacional, no bojo da globalização contemporânea.

No Brasil, a rede urbana tem sido utilizada na explicação de vários fenômenos geográficos. Roberto Lobato Corrêa buscou entender o que ele denominou de "grandes corporações multilocalizadas" (CORRÊA, 2006) por meio de sua vinculação com a rede urbana, identificando centros de produção de matéria-prima, de transformação, de distribuição e de consumo para uma dada empresa. É clássico o emprego da rede urbana para o estudo dos bancos, como pode ser verificado nos trabalhos de Santos e Silveira ([2001] 2011), Corrêa (2006) e Contel (2006). A geógrafa Leila Dias (1995) empregou a rede urbana para compreender os serviços de telecomunicação no Brasil, e Milton Santos relacionou rede urbana e os circuitos da economia urbana (SANTOS, [1979] 2004). 
O estudo Regiões de Influência das Cidades (REGIC) tem sido realizado pelo Instituto Brasileiro de Geografia e Estatística (IBGE) desde a década de 1960, tentando demonstrar as alterações na rede urbana brasileira num intervalo de mais ou menos dez anos. Assim, foram divulgados os REGIC de 1966, 1972, 1987, 1993 e 2007.

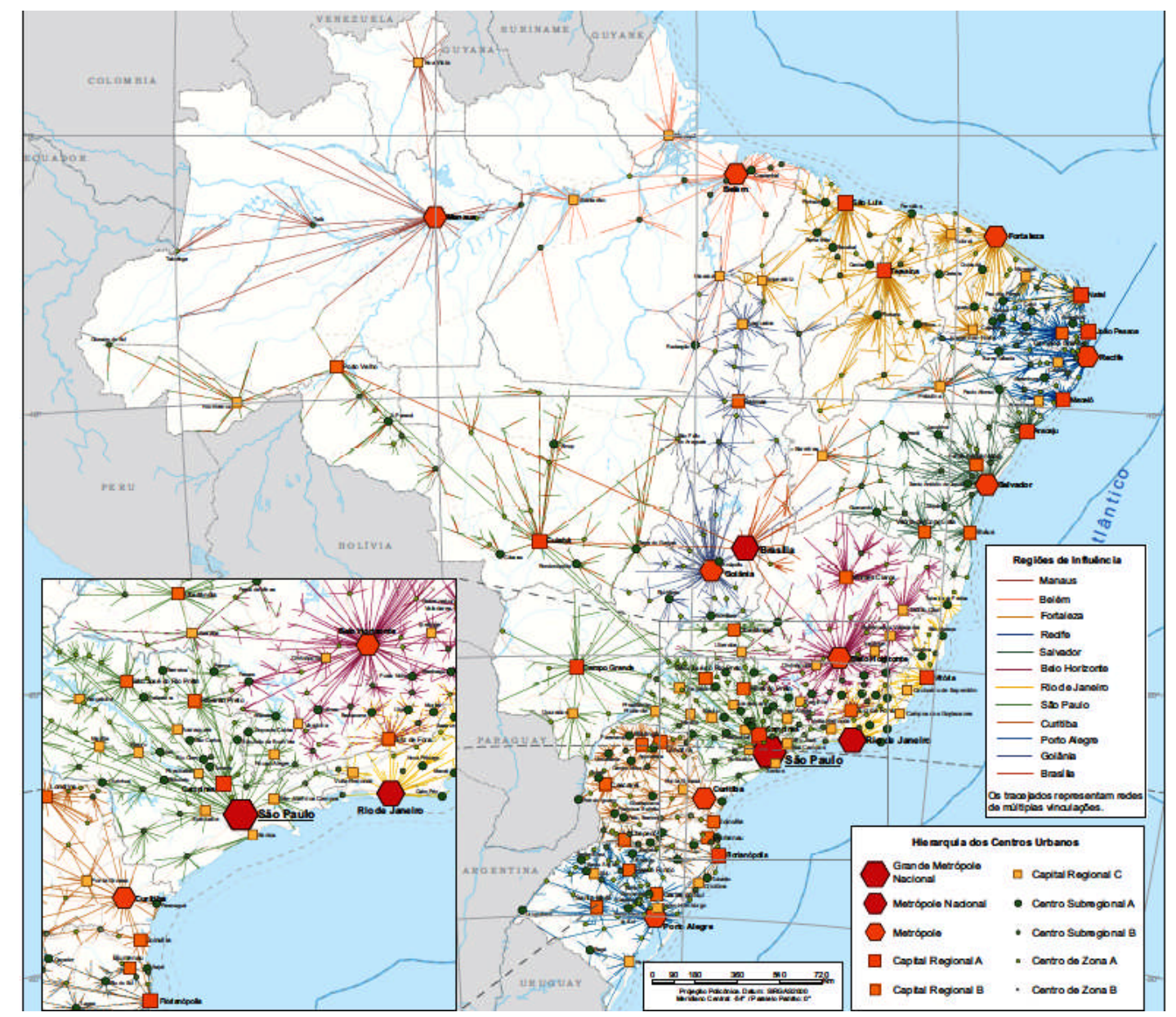

Mapa 14 - Rede urbana brasileira em 2007.

Fonte: IBGE, 2008.

Dentre as críticas feitas ao REGIC, são apontadas vantagens e desvantagens no estudo. Destas últimas, ressalta-se a influência do modelo conservador de Christaller na metodologia empregada, o esquema hierárquico das relações interurbanas, a adoção da mesma tipologia de centros $^{172}$ para todas as regiões brasileiras sem considerar as suas peculiaridades e a invisibilidade a que ficam submetidas as pequenas cidades no resultado final. Dentre as vantagens, figuram a possibilidade de comparações decenais e acompanhamento das transformações estruturais da rede urbana, a identificação de macrotendências para o arranjo

\footnotetext{
${ }^{172}$ Para o último REGIC, as cidades foram classificadas conforme o esquema a seguir: metrópole (grande metrópole nacional, metrópole nacional e metrópole), capital regional (A, B e C), centro sub-regional (A e B), centro de zona (A e B) e centro local.
} 
das cidades no território nacional e a condição de ser o único estudo em escala nacional considerando todos os municípios. Acreditamos que essas vantagens são suficientes para a opção de utilizar o REGIC para os fins deste trabalho.

Dentre as características da rede urbana brasileira apresentadas no REGIC 2007 (Mapa 14), é possível destacar a maior complexidade da rede e diferenciação dos centros na Região Concentrada. Também nota-se uma hierarquia entre as metrópoles, com a primazia de São Paulo como grande metrópole nacional, seguida do Rio de Janeiro e Brasília como metrópoles nacionais e depois as demais metrópoles, que cumprem funções mais regionais, que são: Porto Alegre, Curitiba, Belo Horizonte, Goiânia, Salvador, Recife, Fortaleza, Belém e Manaus. Há influência de duas ou mais metrópoles no que podemos identificar como "áreas de transição" entre regiões, como no Oeste da Bahia, sul do Pará, triângulo mineiro e Rondônia, além do limite relativamente fluido entre unidades da federação, com influência das cidades não correspondendo exatamente ao limite dos estados. Por fim, assinala-se a ampliação do papel das cidades médias (as capitais regionais) no conjunto da rede urbana nacional.

\subsection{Tipologia e topologia dos Correios e rede urbana: similitudes e diferenças}

Uma análise da tipologia e da topologia dos Correios auxilia no reconhecimento de similitudes e diferenças entre uma rede postal e a rede urbana. A qualidade das conexões entre as cidades por meio do serviço postal não tem sido considerada nos estudos geográficos como um elemento constitutivo da rede urbana. Embora não tenhamos a pretensão de esgotar essas possibilidades, apontaremos a seguir algumas características dessa imbricação considerando os fixos, por um lado, e os fluxos, por outro. Essa separação tem apenas uma pretensão metodológica, pois ambos os elementos se interdeterminam.

\subsubsection{Os fixos postais}

A dimensão dos fluxos foi privilegiada na maior parte dos estudos sobre o correio, relegando aos fixos um papel secundário. De acordo com Gertel (1991, p.129), “o sistema postal e telegráfico, então, que sempre foram considerados como fluxo, hoje são também um fixo. Um serviço fixo para o fluxo da correspondência (...)". Assim, a geografia dos fixos geográficos dos Correios é também a geografia dos fluxos, já que os fixos se especializam conforme a quantidade e qualidade dos fluxos de correspondências e encomendas. 
Os fixos geográficos são, ao mesmo tempo, elemento de integração e de diferenciação territorial. Os "fixos postais", as unidades dos Correios desde agências de postagem até centros logísticos especializados, estão presentes em todos os municípios, sendo um elemento de integração territorial que articula a rede urbana. Essas unidades são produto do investimento da empresa em "capital fixo", para usar uma expressão de Marx, sem o qual os fluxos não podem circular. O que muda é a quantidade e diversidades dos fixos geográficos, que se constitui numa expressão da própria hierarquia das cidades e regiões, expressando a divisão do trabalho entre elas (Quadro 10).

Os principais fixos geográficos dos Correios foram divididos em três grupos, conforme a etapa do fluxo postal correspondente a cada um deles. Para a coleta de objetos postais (postagem), existem seis tipos principais, todos eles obedecendo a um padrão locacional que segue as áreas comerciais e de grande circulação de pessoas. O mais antigo e abundante dentre todos os fixos de postagem é a caixa de coleta, com mais de dezoito mil unidades espalhadas por todas as cidades (Fotografia 15). O uso que ainda é feito da caixa de coleta revela a convivência de um elemento velho em meio aos novos objetos informacionais. A agência de Correios (AC) é o canal convencional mais utilizado para a postagem, sendo que a partir de $1978^{173}$ todos os municípios brasileiros passaram a contar com pelo menos uma unidade (GERTEL, 1991). Desde então, os Correios iniciaram um plano de expansão da rede de atendimento com a criação de agências comunitárias (ACC) em vilas, povoados, bairros precários e na zona rural de vários municípios, expandindo a sua capilaridade para além das próprias áreas urbanas oficiais. Complementarmente, a postagem pode ser feita também em canais alternativos, como as agências franqueadas (ACF), presentes nas maiores cidades. No sistema de franquias, o investimento é feito pelo agente franqueado e os lucros são partilhados, sendo que os Correios mantêm o controle de todas as ações, desde o horário de funcionamento até os serviços disponibilizados. É digno de nota que nas cidades com ACFs a empresa mantém no mínimo uma agência própria. Importante destacar que as agências franqueadas correspondem a menos de $3 \%$ das unidades dos Correios, cujo total de pouco mais de 1000 unidades é incomparavelmente menor que as 6449 ACs, as 4577 ACCs ou as mais de 9000 unidades de distribuição (UD). Além dessas, há também postos de vendas de produtos e agências especializadas em produtos filatélicos, que completam a rede de atendimento.

\footnotetext{
${ }^{173}$ Interessante notar que o ano no qual o serviço postal completou sua presença em todos os municípios foi o mesmo da promulgação da Lei Postal, que instituiu o monopólio estatal e a universalização dos serviços. Esse alcance foi possível graças às ações que vinham sendo executadas desde a criação da ECT, uma década anterior.
} 


\begin{tabular}{|c|c|c|c|c|}
\hline \multirow{7}{*}{ 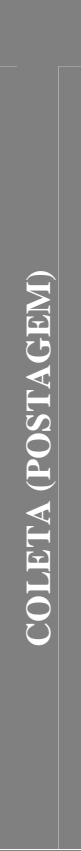 } & FIXO POSTAL & FUNÇÃO & QTDE. & LOCALIZAÇÃO \\
\hline & $\begin{array}{l}\text { Agência de Correios } \\
\text { Própria (AC) }\end{array}$ & $\begin{array}{c}\text { Captar as postagens de objetos } \\
\text { postais }\end{array}$ & 6.449 & $\begin{array}{l}\text { Todas as cidades, sedes dos } \\
5570 \text { municípios }\end{array}$ \\
\hline & $\begin{array}{l}\text { Agência de Correios } \\
\text { Franqueada (ACF) }\end{array}$ & $\begin{array}{l}\text { Captar as postagens de maneira } \\
\text { complementar às ACs }\end{array}$ & 1.016 & $\begin{array}{l}\text { Nas áreas comerciais mais } \\
\text { dinâmicas das metrópoles, } \\
\text { capitais regionais e centros } \\
\text { subregionais }\end{array}$ \\
\hline & $\begin{array}{l}\text { Agência de Correios } \\
\text { Comunitária (ACC) }\end{array}$ & $\begin{array}{c}\text { Captar as postagens de } \\
\text { correspondências em áreas } \\
\text { afastadas dos centros urbanos }\end{array}$ & 4.577 & $\begin{array}{l}\text { Zona rural, vilas, povoados } \\
\text { e bairros precários }\end{array}$ \\
\hline & Agência Filatélica (AF) & $\begin{array}{l}\text { Vender, de maneira } \\
\text { especializada, selos e outros } \\
\text { produtos filatélicos }\end{array}$ & 31 & $\begin{array}{l}\text { Metrópoles e principais } \\
\text { capitais regionais }\end{array}$ \\
\hline & $\begin{array}{l}\text { Posto de Vendas de } \\
\text { Produtos (PV) }\end{array}$ & $\begin{array}{c}\text { Balcão para vendas de selos, } \\
\text { embalagens e produtos } \\
\text { exclusivos }\end{array}$ & 1.529 & $\begin{array}{l}\text { Interior de lojas ou } \\
\text { shopping centers das } \\
\text { metrópoles e capitais } \\
\text { regionais }\end{array}$ \\
\hline & Caixa de Coleta (CC) & $\begin{array}{l}\text { Coletar correspondências já } \\
\text { seladas para a postagem }\end{array}$ & 18.424 & $\begin{array}{l}\text { Principais logradouros de } \\
\text { todas as cidades do país }\end{array}$ \\
\hline \multirow{8}{*}{ 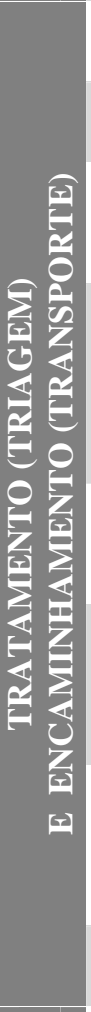 } & $\begin{array}{l}\text { Centro de Tratamento de } \\
\text { Cartas (CTC) }\end{array}$ & $\begin{array}{l}\text { Triar e encaminhar os objetos do } \\
\text { segmento mensagem }\end{array}$ & 16 & $\begin{array}{c}\text { Metrópoles e algumas } \\
\text { capitais regionais }\end{array}$ \\
\hline & $\begin{array}{l}\text { Centros de Tratamento de } \\
\text { Encomendas (CTE) Manual }\end{array}$ & $\begin{array}{l}\text { Triar e encaminhar os objetos do } \\
\text { segmento encomenda }\end{array}$ & 5 & $\begin{array}{l}\text { Algumas metrópoles e } \\
\text { capitais regionais }\end{array}$ \\
\hline & $\begin{array}{l}\text { Centro de Tratamento de } \\
\text { Encomendas (CTE) } \\
\text { Automatizado }\end{array}$ & $\begin{array}{l}\text { Triar e encaminhar os objetos do } \\
\text { segmento encomenda por } \\
\text { procedimentos automáticos }\end{array}$ & 12 & $\begin{array}{l}\text { Principais metrópoles e } \\
\text { algumas capitais regionais }\end{array}$ \\
\hline & $\begin{array}{l}\text { Centro de Tratamento de } \\
\text { Cartas e Encomendas } \\
\text { (CTCE) }\end{array}$ & $\begin{array}{c}\text { Triar e encaminhar os objetos } \\
\text { dos segmentos mensagem e } \\
\text { encomenda }\end{array}$ & 25 & $\begin{array}{c}\text { Algumas metrópoles e } \\
\text { capitais regionais onde o } \\
\text { volume da carga não } \\
\text { justifica a existência de } \\
\text { CTC e CTE separadamente }\end{array}$ \\
\hline & $\begin{array}{l}\text { Centro de Tratamento de } \\
\text { Correio Internacional } \\
\text { (CTCI) }\end{array}$ & $\begin{array}{l}\text { Triar e encaminhar objetos de } \\
\text { todos os segmentos destinados a } \\
\text { ou originados em outros países }\end{array}$ & 3 & Metrópoles nacionais \\
\hline & $\begin{array}{l}\text { Centro de Logística } \\
\text { Integrada (CLI) }\end{array}$ & $\begin{array}{c}\text { Operacionalizar o tratamento de } \\
\text { objetos de serviços } \\
\text { especializados como logística } \\
\text { reversa }\end{array}$ & 59 & $\begin{array}{l}\text { Metrópoles e capitais } \\
\text { regionais }\end{array}$ \\
\hline & $\begin{array}{l}\text { Posto de Atendimento } \\
\text { Avançado (PA) }\end{array}$ & $\begin{array}{c}\text { Captar as postagens e realizar } \\
\text { tratamento e encaminhamento } \\
\text { inicial de encomendas de grandes } \\
\text { clientes }\end{array}$ & 2 & Grande metrópole nacional \\
\hline & $\begin{array}{l}\text { Terminal de Cargas } \\
\text { (TECA) }\end{array}$ & $\begin{array}{l}\text { Encaminhar grandes volumes de } \\
\text { carga postal previamente tratada }\end{array}$ & 7 & Metrópoles nacionais \\
\hline \multirow{3}{*}{ 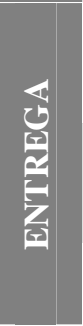 } & $\begin{array}{l}\text { Unidades de Distribuição } \\
\text { (UD) }\end{array}$ & $\begin{array}{l}\text { Entregar as correspondências de } \\
\text { todos os segmentos }\end{array}$ & 9.196 & $\begin{array}{l}\text { Centros sub-regionais } \mathrm{B}, \\
\text { Centros de zona e centros } \\
\text { locais }\end{array}$ \\
\hline & $\begin{array}{l}\text { Centro de Distribuição } \\
\text { Domiciliária (CDD) }\end{array}$ & $\begin{array}{l}\text { Entregar as correspondências do } \\
\text { segmento mensagem }\end{array}$ & 997 & $\begin{array}{l}\text { Metrópoles, capitais } \\
\text { regionais e centros sub- } \\
\text { regionais A }\end{array}$ \\
\hline & $\begin{array}{l}\text { Centro de Entrega de } \\
\text { Encomendas (CEE) }\end{array}$ & $\begin{array}{l}\text { Entregar as correspondências do } \\
\text { segmento encomenda }\end{array}$ & 126 & $\begin{array}{l}\text { Metrópoles e capitais } \\
\text { regionais A }\end{array}$ \\
\hline
\end{tabular}

Quadro 10 - Tipologia dos principais fixos geográficos postais no Brasil, 2016. Localização referente à hierarquia urbana do REGIC/IBGE 2007.

Fonte: Elaboração própria a partir de trabalhos de campo e Relatório da Administração dos Correios 2014. 


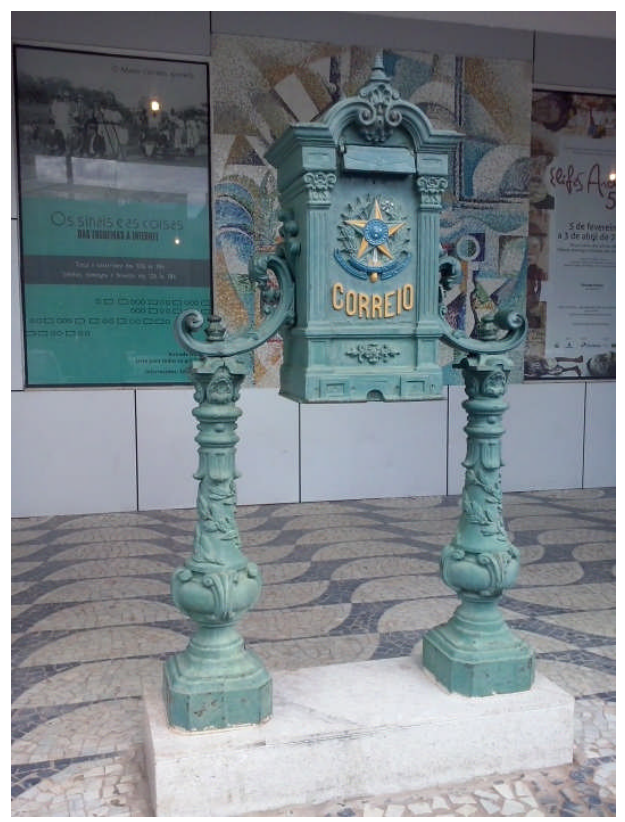

Fotografia 15 - Exemplar do primeiro modelo brasileiro de caixa de coleta (século XIX), encontrado no Museu dos Correios.

Fonte: Trabalho de campo realizado em março de 2016, em Brasília-DF.

Foto: Igor Venceslau.

A entrega ao destinatário, no final do processo, é a segunda etapa com maior número de fixos geográficos. Essas unidades dos Correios são encontradas, preferencialmente, próximas a áreas residenciais e em áreas comerciais que possuem grande volume de entregas. A unidade de distribuição (UD) é o fixo postal mais banal desse tipo, com mais de nove mil deles espalhados por todo o país, contemplando as menores cidades com volumes reduzidos de entrega. Em muitos casos a UD e a AC se confundem, sendo a unidade de postagem a mesma de entrega. Nas cidades médias e grandes, onde os fluxos são mais intensos, a entrega é feita por um centro de distribuição (CDD), que congrega os carteiros da cidade ou de parte dela. Nas metrópoles e cidades médias de maior relevância (capital regional A), o CDD entrega apenas os objetos do segmento mensagem, enquanto o centro de entrega de encomendas (CEE) leva objetos de serviços como PAC e SEDEX até o endereço do destinatário.

Apesar de possuir menor número total de unidades dos Correios, a etapa de tratamento (triagem) e encaminhamento (transporte) apresenta a maior diversificação de tipos de fixos postais diferentes. Essa pode ser considerada a etapa crucial de todo o processo logístico, pois se trata do elo entre o local de postagem e o local da entrega. Racionalizar a etapa intermediária pode significar ganhos de tempo na circulação dos objetos e, consequentemente, a garantia do cumprimento dos prazos de entrega.

Dos oito tipos principais de fixos postais de tratamento e encaminhamento, um deles é especializado em fluxos externos e corresponde aos pontos de contato entre a rede postal nacional e a internacional. Apenas as cidades de São Paulo, Rio de Janeiro e Curitiba possuem 
um Centro de Tratamento de Correio Internacional (CTCI), sendo que entre elas também se estabelece uma divisão do trabalho: as encomendas expressas entram e saem pela capital paulista; o CTCI Rio é especializado em encomendas não expressas; e a capital paranaense se responsabiliza pelos objetos internacionais não expressos do segmento mensagem, como menos de 1 quilograma de peso. Essa divisão afirma o papel de São Paulo na rede urbana brasileira, como a grande metrópole com maior fluidez, por onde os fluxos podem passar com maior velocidade.

As unidades de tratamento e encaminhamento dos fluxos postais nacionais são divididas conforme o segmento de serviço. Dezesseis centros de tratamento de cartas (CTC), encontrados nas metrópoles e em algumas capitais regionais, realizam a articulação das mensagens no Brasil. Para as encomendas, os Correios criaram um fixo postal à parte, o centro de tratamento de encomendas (CTE), no total de dezessete unidades, sendo a maioria deles automatizados (com máquina de triagem) e apenas cinco com tratamento manual ${ }^{174}$. Contudo, como os fluxos postais são desiguais no território, nem todos os lugares justificam a instalação de CTC e CTE, levando a empresa a criar centros de tratamento integrado para cartas e encomendas (CTCE) em algumas metrópoles e capitais regionais com menor volume de carga. Essas unidades se articulam nacionalmente por meio dos sete terminais de carga (TECA) localizados nos principais nós de integração das redes aérea (RPN) e rodoviária $(\mathrm{LTN})^{175}$.

Ainda há fixos postais para tratamento e encaminhamento de objetos oriundos de serviços mais especializados, como os centros de logística integrada (CLI) localizados nas metrópoles e capitais regionais para operações logísticas sazonais ou dar conta da logística reversa. Por fim, há o fixo postal mais recente e raro, o Posto de Atendimento Avançado (PA), cuja especificidade só permite ser encontrado em São Paulo, a grande metrópole nacional: nessa unidade são postados, tratados e encaminhados com exclusividade objetos de grandes clientes dos Correios, as empresas de comércio eletrônico, que contam com o atendimento dos Correios dentro ou próximo de suas instalações.

À complexidade desses fixos geográficos especializados some-se uma logística interna da empresa, montada pelos Correios para suprir as unidades de postagem, tratamento e

\footnotetext{
${ }^{174}$ Os centros automatizados são: três em São Paulo: CTE Jaguaré, CTE Saúde e CTE Vila Maria; as demais cidades com uma unidade cada: CTE Campinas, CTE Benfica (Rio de Janeiro), CTE Belo Horizonte, CTE Curitiba, CTE Londrina, CTE Florianópolis, CTE Porto Alegre, CTE Brasília e CTE Recife. Os centros manuais são: CTE Cajamar-SP, CTE Sorocaba-SP, CTE São José dos Campos-SP, CTE São Gonçalo-RJ e CTE Salvador-BA.

${ }^{175}$ Três em São Paulo: TECA Jaguaré, TECA Rodoanel e TECA Guarulhos; dois no Rio de Janeiro: TECA Galeão e TECA Benfica; o TECA do aeroporto de Brasília; e o TECA do aeroporto de Salvador.
} 
entrega com os produtos e equipamentos necessários. Para o seu funcionamento, as agências e demais fixos postais necessitam de: produtos para a venda, como selos, caixas, envelopes; materiais de consumo, como papeis timbrados para a impressão, formulários, carimbos, etc.; fardamento para funcionários, placas e adesivos informativos, entre outros. Essa logística interna é realizada por dois centros de distribuição (CD), estando o CD Leste em São Paulo e o CD Oeste em Brasília, de onde os materiais são distribuídos.

Ao observar a distribuição geográfica dos fixos postais especializados no tratamento e encaminhamento de objetos SEDEX e outros serviços expressos - CTE automatizado e manual, CTCE, CTCI e TECA (Mapa 15) - nota-se a predominância da Região Concentrada, com 31 unidades contra apenas 18 das demais regiões somadas.

Todos os centros internacionais estão localizados na Região Concentrada, além da maioria dos terminais de carga. Olhando sob o prisma da automação, verifica-se que também a Região Concentrada é a mais automatizada, sendo que nas demais a maior parte dos fixos postais realizam trabalhos manuais, mais lentos. Ainda assim, a concentração de todos os tipos de fixos é uma característica dessa região, contando também com um grande número de centros não automatizados e menos especializados (CTCE).

Há uma predominância metropolitana na topologia dos Correios, assim como na rede urbana brasileira. Desta maneira, as unidades postais de maior complexidade, com maior capacidade operacional e justamente as que autorizam maior velocidade dos fluxos localizarse-ão nos centros urbanos de mais alto escalão, notadamente as metrópoles. Dessas, Rio de Janeiro e Brasília mantém algum destaque, articulando fluxos que extrapolam suas áreas de influência. No entanto, a grande metrópole nacional é São Paulo, inclusive para o serviço postal: sua relevância é estabelecida pela quantidade dos fixos geográficos que possui, mas também por sua qualidade, a única metrópole a congregar todos os tipos de unidades operacionais. Assim, os fluxos postais controlados pela capital paulista são de toda a ordem e de todos os lugares do país.

Ratifica-se a tendência de reforço às capitais estaduais. Muitas das capitais de estados ocupam escalões hierárquicos inferiores às metrópoles na rede urbana brasileira, mas os fixos geográficos dos Correios acabam por conferir-lhes algum destaque. Assim, metrópoles como Manaus, Fortaleza, Belém e Goiânia possuem unidades operacionais tal qual Porto Velho, Teresina e Campo Grande. Embora a função metropolitana não desapareça nessa topologia, sobretudo naquelas que possuem os CTEs automatizados, a maioria das capitais estaduais é convocada a cumprir funções superiores à sua própria demanda de fluxos. 


\section{Brasil: Fixos postais especializados em serviços expressos, 2016}

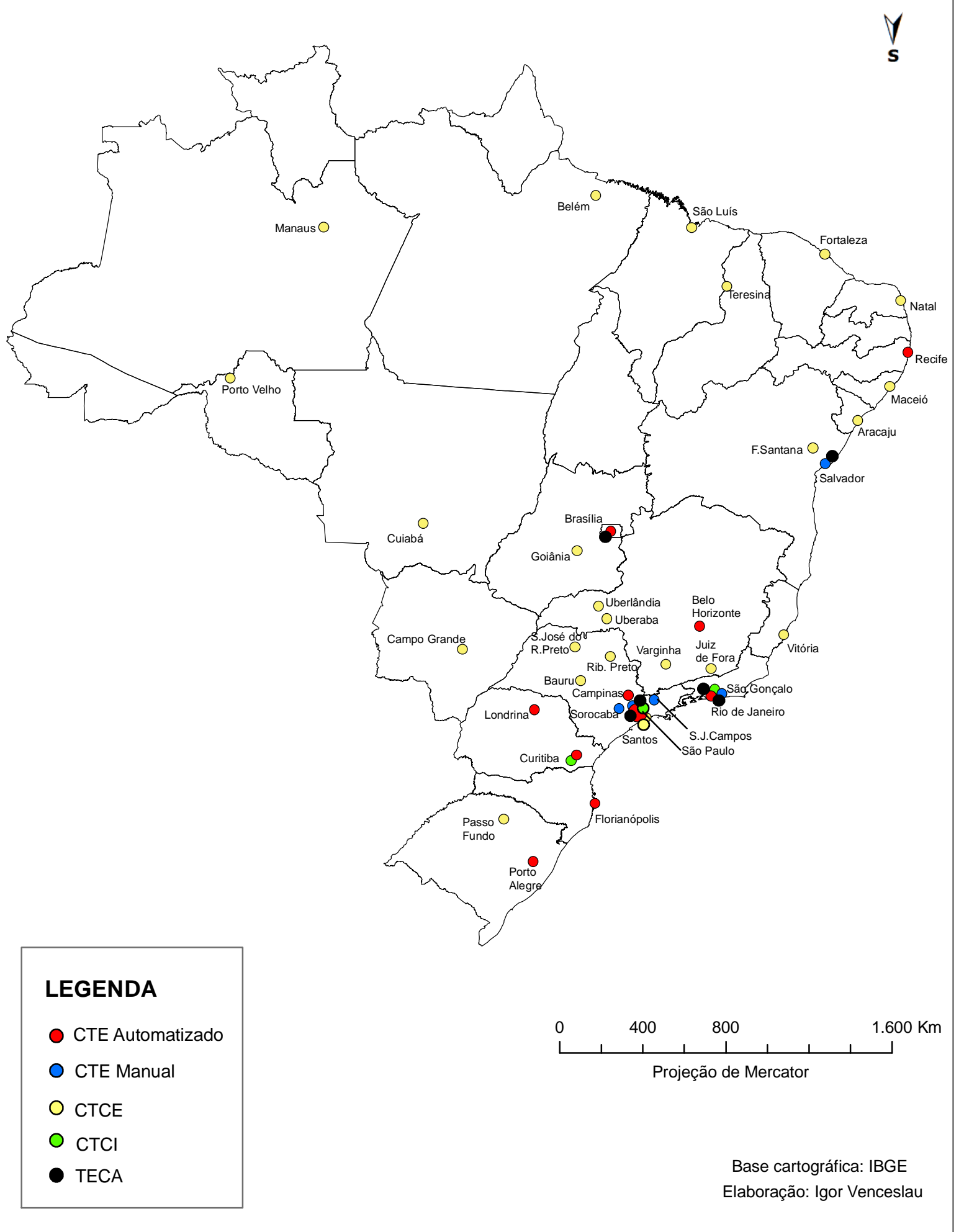

Mapa 15 - Brasil: fixos postais especializados em serviços expressos, 2016.

Fonte: Elaboração própria a partir de dados da Vice-Presidência de Encomendas dos Correios e trabalhos de campo. 
Excetuando-se o município central das metrópoles, os demais municípios metropolitanos tendem a não apresentar fixos especializados, como também não apresentam maior importância no REGIC. Para os Correios, apenas as regiões metropolitanas de São Paulo e Rio de Janeiro apresentam fixos especializados nesses municípios, embora na metrópole paulista isso corresponda à própria divisão metropolitana do trabalho (vide item 4.3.2). O caso fluminense é revelador da importância do lugar para a circulação e a logística. A decisão de instalar um CTE no município de São Gonçalo foi grandemente relacionada às condições locais de fluidez, uma vez que o acesso exclusivo ao outro lado da Baía de Guanabara pela ponte Rio-Niterói gerava atrasados e impossibilidade de cumprimento dos prazos do SEDEX $^{176}$. Com o CTE São Gonçalo, as encomendas destinadas ao município, além de Niterói, Itaboraí, entre outros, são transportadas diretamente de/para o TECA Galeão ou mesmo pelo modal rodoviário para outros estados, assegurando os prazos.

Algumas cidades médias (principalmente as capitais regionais A) possuem fixos postais especializados, revelando a importância dessas cidades no conjunto da rede urbana nacional ${ }^{177}$. Com exceção de Feira de Santana-BA, por motivo de sua situação geográfica já apontado, todas elas se localizam na Região Concentrada, especialmente nos estados de São Paulo, Minas Gerais, Paraná e Rio Grande do Sul. As cidades de Campinas ${ }^{178}$ (principalmente) e Londrina cumprem funções, nessa logística, equiparadas àquelas das metrópoles. Depois, Sorocaba e São José dos Campos-SP possuem fixos postais com grande capacidade operacional, apesar de não serem automatizados. Em seguida, várias cidades do interior desempenham atribuições de entrepostos dos fluxos postais: Passo Fundo, Juiz de Fora, Varginha, Uberaba, Uberlândia, Santos, Bauru, Ribeirão Preto e São José do Rio Preto.

Se os fluxos informacionais podem se concentrar num só ponto, geralmente um centro de processamento de dados, os fluxos materiais continuam exigindo escalões intermediários da rede urbana para a sua distribuição. Na topologia dos Correios, não desaparecem as diferenças de hierarquia entre as cidades, embora seja possível para algumas delas romper com o padrão e articular-se com centros de níveis superiores, principalmente na Região

\footnotetext{
${ }^{176}$ Informações adquiridas em trabalho de campo realizado no CTE Jaguaré em outubro de 2014.

177 Ainda que as legislações estaduais venham criando uma série de regiões metropolitanas (como Londrina-PR, Ribeirão Preto-SP e Feira de Santana-BA), estamos considerando como metrópoles aqueles centros urbanos que possuem esse estatuto no estudo do REGIC 2007 do IBGE.

${ }^{178}$ Apesar de não possuir status metropolitano no REGIC, a cidade de Campinas pode ser considerada como metrópole, conforme vários estudos já realizados por geógrafos.
} 
Concentrada. No caso das menores capitais estaduais, vê-se que a política dos Correios é capaz de induzir, por meio dos fixos geográficos, uma menor desigualdade regional.

Esses lugares centrais na topologia dos Correios podem ser considerados como os centros de gestão (dos fluxos) do território, cuja posição hierárquica na rede urbana depende, em grande medida, da dinâmica dos serviços postais de suas respectivas regiões. Quanto maior o volume de postagem ou de entregas, maior a necessidade de fixos postais especializados que garantam a aceleração dos fluxos e o cumprimento dos prazos. Somente pela dinâmica econômica do território é possível compreender essas atualizações técnicas. A posição destacada de Londrina (e em breve, Uberlândia ${ }^{179}$ ), mais relevantes que Cuiabá ou Natal, aponta para a complexidade de relações em regiões como o Norte do Paraná e o Triângulo Mineiro. O mesmo pode ser atribuído para grande parte do interior de São Paulo, sul de Minas Gerais, noroeste gaúcho, dentre outras.

\subsubsection{Os fluxos postais}

O correio brasileiro assiste a um vertiginoso crescimento do fluxo postal nas últimas décadas (Gráfico 4). Se logo após os Correios alcançarem a capilaridade de todo o território nacional o volume de objetos era de pouco mais de 3 bilhões, na virada para o século XXI esse número tinha dobrado. Contudo, o crescimento mais rápido é registrado entre 2001 e 2011, década na qual o fluxo postal atinge a marca de 9 bilhões de objetos. Desde então, o fluxo postal vem se mantendo entre 8 e 10 bilhões de mensagens e encomendas postadas no Brasil. Essa quantidade de postagens recentes revela a importância atual do correio, mesmo com o difusão das novas tecnologias de comunicação.

Concomitantemente ao aumento da quantidade, há uma diversificação na qualidade dos fluxos, conforme foram sendo criados novos serviços, principalmente os expressos com suas diferentes temporalidades. Contribui enormemente para o aumento do fluxo postal o segmento de encomendas que foi impulsionado a partir das práticas de compras pela Internet. Somente o total de objetos expressos no Brasil saltou de 170 milhões em 2005 para mais de 210 milhões de unidades postadas em 2014, segundo dados da UPU. A direção dos fluxos também corrobora para esse incremento. Conforme aumenta a capilaridade dos Correios, amplia-se sua rede de captação e entrega, interligando desde as áreas centrais das metrópoles até remotas áreas rurais.

\footnotetext{
${ }^{179}$ Com a decisão da empresa de automatizar o CTCE Uberlândia, esta cidade mineira deverá ser a próxima a endossar a lista das cidades médias que ocupam o topo da hierarquia dos Correios.
} 


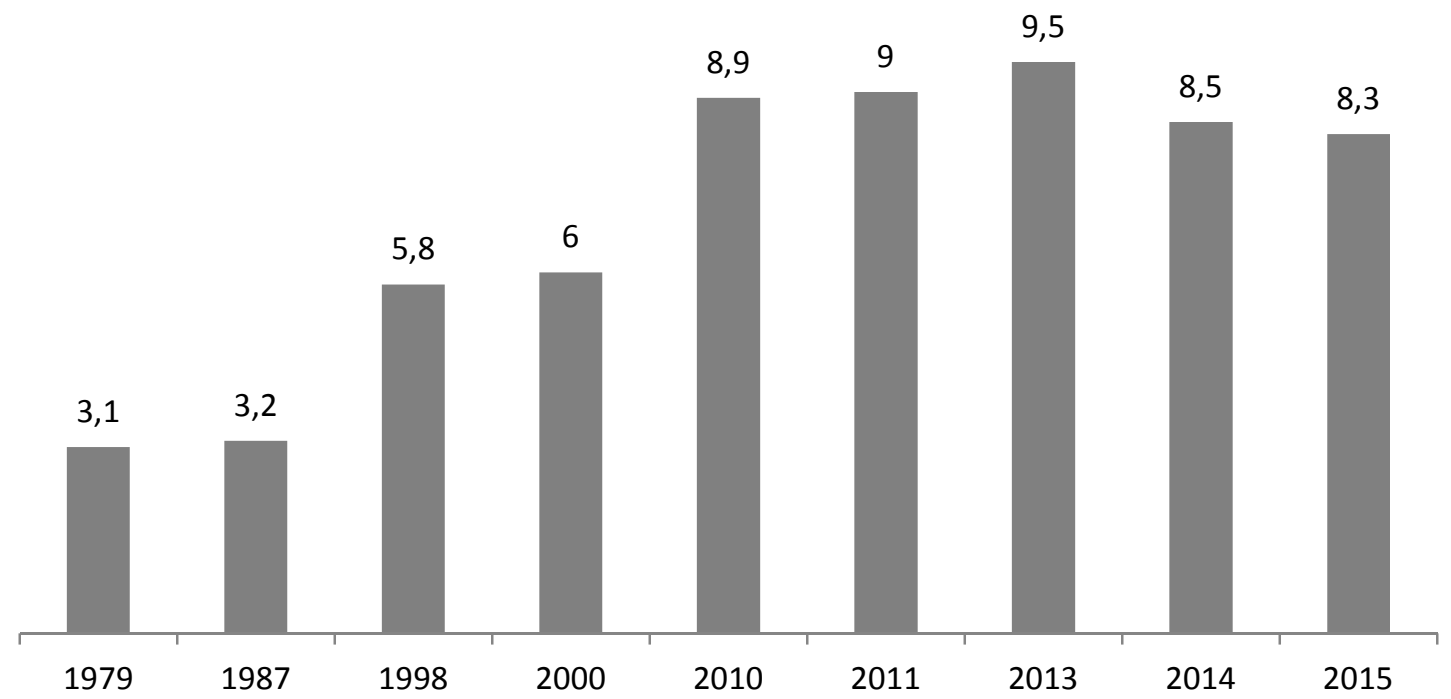

Gráfico 4 - Fluxo postal no Brasil em bilhões de objetos postados em anos selecionados entre 1979 e 2015. Fonte dos dados: Relatórios anuais dos Correios e Gertel (1991).

Considerando os fixos e os fluxos postais em relação à rede urbana brasileira, elaboramos um esquema da topologia dos Correios que contempla os diferentes níveis hierárquicos das cidades, com os respectivos tipos de transporte utilizados, os prazos de entrega e as modalidades de serviços expressos oferecidos para cada um deles (Diagrama 1). Esse esquema possui correspondência com os mapas apresentados em Braudel ([1966] 1983) e reproduzidos na introdução. Ambos têm uma localidade central na rede do correio, com anéis concêntricos que representam os prazos de entrega. A diferença, contudo, é que para o século XVI esses anéis puderam ser representados considerando o mapa da Europa ao fundo; hoje, com as novas tecnologias de transporte e informação, essa distâncias se relativizam ainda mais, e a as áreas de mesmo prazo de entrega não podem ser representadas contiguamente, apesar de não desaparecerem as distâncias e continuarem importando para o cálculo dos prazos.

Estamos utilizando a distinção feita pelo geógrafo francês Jacques Lévy (1993) para o espaço geográfico, considerando-o a partir de duas métricas. A uma métrica topográfica corresponderia uma distância física, podendo ser medida em quilômetros. Outra métrica seria a topológica, que se aproxima da ideia de rede e está mais relacionada com uma distânciatempo. A topologia dos Correios pode ser compreendida a partir dessa definição, considerando seu aspecto territorial com as distâncias que se traduzem antes em prazos de entrega do que em quilômetros. 


\section{LEGENDA}

Hierarquia urbana

$\rightarrow$ Transporte

$\rightarrow$ Tempo

$\rightarrow$ Serviço expresso

$\longrightarrow$ Área de concorrência com as multinacionais

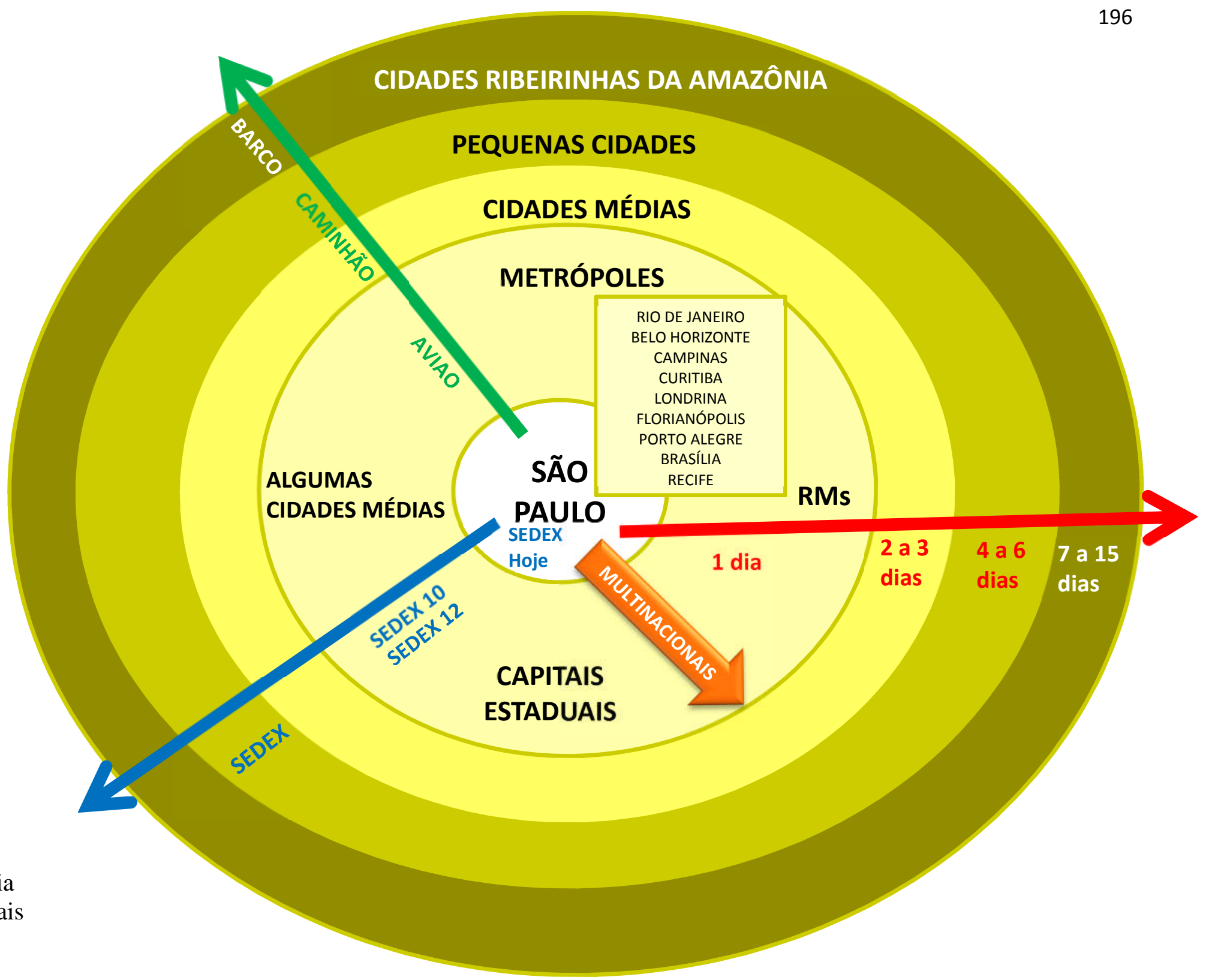

Diagrama 1 - Esquema topológico dos Correios no Brasil, 2016.

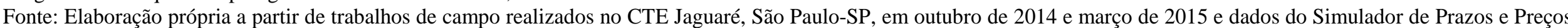
dos Correios. 
No centro da topologia dos Correios está a metrópole de São Paulo, ponto de máxima fluidez territorial a partir do qual o serviço de SEDEX Hoje já é plenamente possível. A partir dali, em 1 dia útil as postagens são entregues nas demais metrópoles e suas respectivas regiões metropolitanas, nas capitais estaduais e em algumas cidades médias do país. Dentre essas cidades, destacam-se aquelas dotadas de maiores condições de fluidez para os fluxos postais, que são: Campinas, Rio de Janeiro, Belo Horizonte, Curitiba, Londrina, Florianópolis, Porto Alegre, Brasília e Recife. Esses são os espaços da rapidez, não contíguos e articulados em rede pelo transporte aéreo, onde são oferecidos os serviços SEDEX 10 e SEDEX 12, com entrega programada. Esse também é o espaço de atuação privilegiado das empresas multinacionais de correio - FedEx, UPS e DHL -, cujas ações são seletivas e exigentes de fluidez (Fotografias 16 e 17). Olhando pelo prisma do território, não há como concordar com Mesquita (2012) quando a autora se queixa de um suposto "regime jurídico privilegiado e protetivo" para os Correios, que seria um "entrave”. Ora, reclama-se um tratamento igualitário para as empresas privadas, mas esconde-se que estas mesmas não tratam o território nacional igualmente à empresa pública, nem possuem as mesmas obrigações.

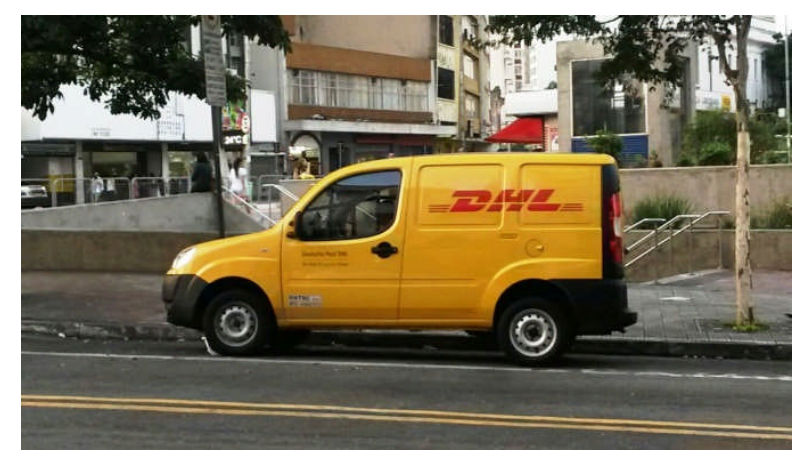

Fotografia 16 - Veículo de entrega da empresa DHL no bairro da Liberdade, em São Paulo-SP.

Fonte: Trabalho de campo realizado em abril de 2016. Foto: Wagner Nabarro.

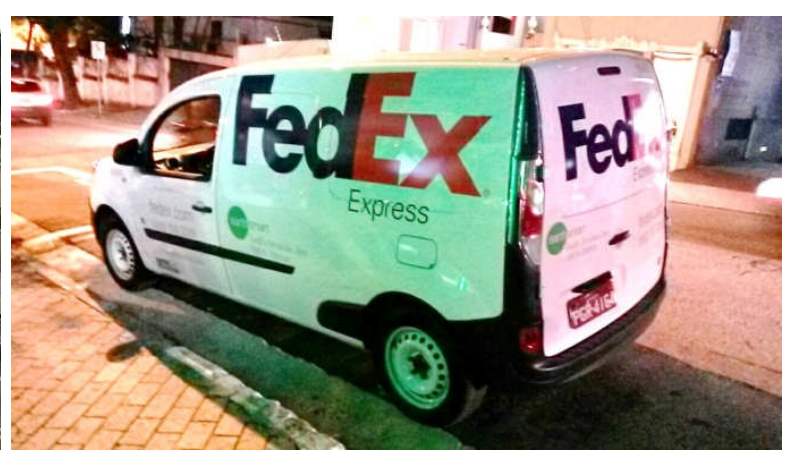

Fotografia 17 - Veículo de entrega da empresa FedEx no bairro dos Jardins, em São Paulo-SP.

Fonte: Trabalho de campo realizado em abril de 2016. Foto: Igor Venceslau.

Num terceiro círculo estão as demais cidades médias, muitas delas localizadas nas regiões Centro-Oeste, Nordeste e Amazônia, onde os serviços expressos só as alcançam com 2 a 3 dias úteis depois da postagem. O modal de transporte privilegiado para esses lugares é o rodoviário, que transporta o SEDEX convencional. Também as pequenas cidades estão sujeitas ao mesmo procedimento logístico, mas as encomendas são entregues, na maioria dos casos, entre 4 e 6 dias, por causa da maior quantidade de centros intermediários pelos quais passa. Por fim, há um último círculo correspondente às cidades ribeirinhas da Amazônia, cuja temporalidade peculiar dos fluxos e a viscosidade do território só permite entregas a partir do 
sétimo dia útil. Nesses espaços da lentidão, o barco se torna a única alternativa viável de transporte para conduzir os objetos postais.

Nesse esquema topológico dos Correios, quanto mais central a posição da cidade, mais intensas serão as interações espaciais estabelecidas com os demais núcleos da rede urbana. Para Corrêa ([1997] 2006, p.279), “as interações espaciais constituem um amplo e complexo conjunto de deslocamentos de pessoas, mercadorias, capital e informação sobre o espaço geográfico". Desta maneira, para algumas cidades médias e as metrópoles, principalmente São Paulo, as interações espaciais estabelecidas com o restante do território são mais complexas e atribuem a esses lugares um papel de destaque na divisão territorial do trabalho.

De fato, o que se verifica é a existência de centralidades de diferentes naturezas: uma centralidade dos fluxos e uma centralidade dos fixos. A centralidade dos fluxos é conferida pela intensidade, extensão, volume e velocidade dos fluxos postais em algumas metrópoles e cidades médias. Esse grupo de cidades se articula a outras cidades que se localizam além dos limites de sua respectiva unidade da federação, conseguindo romper com a hierarquia do esquema logístico padrão. São exemplos a ligação direta Londrina (PR) - São Paulo (SP) e Rio de Janeiro (RJ) - Campinas (SP). Por concentrarem os centros automatizados de tratamento de objetos, essas cidades possuem também uma capacidade instalada maior de processamento de carga postal. A velocidade maior dos fluxos se verifica principalmente porque os serviços mais expressos articulam basicamente esse grupo de cidade entre si e, a partir delas, os demais pontos do território. A centralidade dos fixos se refere à localização de centros de tratamento da carga postal em todas as capitais das 26 unidades da federação, cuja função é a mediação entre os fluxos internos e externos à respectiva porção do território. É importante destacar que a produção dessas diferentes centralidades, sobretudo esta última, é uma decisão política do Estado, contribuindo assim para a diminuição das desigualdades do território e para uma rede urbana mais complexa e menos concentrada. Essa ação catalisadora se diferencia das estratégias dos operadores logísticos privados, estudados por Trevisan (2007).

A topologia dos Correios apresenta bastante afinidade com o que Dicken ([1986] 2011) chamou de "convergência do tempo-espaço". Por causa do desigual desenvolvimento das tecnologias de transporte no território, como consequência há uma aproximação relativa de certos lugares dotados de infraestruturas que possibilitam maior fluidez em detrimento dos demais lugares, para os quais pode ser verificada uma condição de relativo afastamento, de maior distância. Para o autor, 
Embora o mundo tenha encolhido em termos relativos, precisamos estar cientes de que tal encolhimento tem sido, e continua a ser, altamente desigual. (...) Na verdade, os desenvolvimentos tecnológicos dos transportes têm uma forte tendência de serem geograficamente concentrados. (...) consequentemente, a convergência do tempo-espaço afeta alguns lugares mais que a outros. Enquanto as principais economias nacionais e as maiores cidades do mundo estão sendo aproximadas em termos relativos de tempo e custo, outras - países menos industrializados ou pequenas cidades e áreas rurais - estão, na realidade, sendo deixadas para trás. A superfície do tempoespaço é altamente plástica; algumas partes encolhem enquanto outras partes se tornam, na realidade, estendidas (Tradução nossa), (DICKEN, 2011, p.86, grifo do autor $)^{180}$

Outra maneira de interpretar o esquema topológico dos Correios no Brasil é consideralo como um exemplo da difusão desigual das modernizações no território, que alcançam primeiramente São Paulo e depois vão se difundindo seletivamente, iniciando pelas metrópoles e algumas cidades médias, depois pelas demais cidades médias, até alcançar as pequenas cidades. De certa maneira, há correspondências com o estudo de Hägerstrand ([1952] 2013) sobre a difusão de inovações na região da Scania, na Suécia, onde o centro difusor correspondia sempre às maiores cidades, até alcançar todo o território com defasagens temporais.

\subsection{A divisão territorial do trabalho imposta à atividade postal}

Conforme já demonstrado, cada parcela do território é convocada a cumprir tarefas específicas na logística dos Correios. Há os lugares que possuem apenas os fixos geográficos postais mais banais, mas também há outros lugares dotados de fixos especializados que os confere algum destaque na rede urbana, o que torna esses pontos mais fluidos para o fluxo postal. Na verdade, não se trata de uma dinâmica do correio em si, mas do dinamismo das atividades econômicas do próprio território, expressado nos serviços postais. Se o correio pode, então, ser considerado como "mais um elemento dinamizador da produção do país" (GERTEL, 1991, p.117), a atual divisão territorial do trabalho se impõe à atividade postal. De que maneira as diferentes regiões brasileiras participam dessa divisão do trabalho?

\footnotetext{
180 "Although the world has shrunk in relative terms, we need to be aware that such shrinkage has been, and continues to be, highly uneven. (...) In fact, technological developments in transportation have a very strong tendency to be geographically concentrated. (...) consequently, time-space convergence affects some places more than others. While the world's leading national economies and the world's major cities are being pulled closer together in relative time or cost terms, others - less industrialized countries or smaller towns and rural areas - are, in effect, being left behind. The time-space surface is highly plastic; some parts shrink whilst other parts become, in effect, extended".
} 


\subsubsection{As regiões brasileiras e os fluxos postais}

Há uma profunda desigualdade regional dos fluxos postais no Brasil (Quadro 11). Considerando as cinco macrorregiões do IBGE, os quatro estados do Sudeste responderam por $70 \%$ das postagens (origem) realizadas em 2015. O restante dos objetos (30\% do total) foi postado, em ordem decrescente, no Sul, Nordeste, Centro-Oeste e, por último, no Norte. Se tomarmos como referência a Região Concentrada, ela responde isoladamente por $86,8 \%$ das postagens, mostrando a concentração da origem das encomendas e correspondências. Essa concentração se deve à concentração das atividades econômicas no Brasil, com maior quantidade de empresas e instituições localizadas nos estados que compõem essa região.

Obviamente que contribui para essa concentração a própria distribuição desigual da população no território. Contudo, é possível verificar essa desigualdade ao realizar um cálculo simples $^{181}$ de objetos postais recebidos per capita em 2015. Na média, cada habitante da região Sudeste recebeu 60 objetos postais (cartas ou encomendas) em 2015, o valor mais alto do país. No Sul foram entregues 51 correspondências por pessoa, contra 43 na região CentroOeste. Na região Norte o valor cai drasticamente para menos de 20 objetos entregues per capita durante todo o ano, um terço da média do Sudeste. O Nordeste encontra-se na mesma situação, com um valor médio de 20,79 correspondências anuais por habitante. Se as condições de acesso ao serviço postal são minimamente igualitárias, com atendimento dos Correios em todos os municípios, o que explica essa disparidade? Certamente a resposta será encontrada no território, com as desigualdades regionais de renda e de consumo no país.

\begin{tabular}{|c|c|c|c|c|c|c|c|}
\hline & & \multicolumn{5}{|c|}{ Destino } & \multirow[b]{2}{*}{ Origem } \\
\hline & Região & $S$ & SE & $\mathrm{CO}$ & NE & $\mathbf{N}$ & \\
\hline \multirow{5}{*}{ 离 } & $S$ & $8,3 \%$ & $6,0 \%$ & $0,9 \%$ & $1,2 \%$ & $0,4 \%$ & $16,8 \%$ \\
\hline & SE & $7,9 \%$ & $48,7 \%$ & $4,2 \%$ & $7,1 \%$ & $2,1 \%$ & $70,0 \%$ \\
\hline & $\mathrm{CO}$ & $0,4 \%$ & $1,5 \%$ & $1,8 \%$ & $0,4 \%$ & $0,3 \%$ & $4,5 \%$ \\
\hline & NE & $0,3 \%$ & $1,8 \%$ & $0,3 \%$ & $4,4 \%$ & $0,3 \%$ & $7,1 \%$ \\
\hline & $\mathbf{N}$ & $0,1 \%$ & $0,4 \%$ & $0,1 \%$ & $0,2 \%$ & $0,7 \%$ & $1,5 \%$ \\
\hline & Destino & $17,0 \%$ & $58,5 \%$ & $7,3 \%$ & $13,3 \%$ & $3,8 \%$ & $100,0 \%$ \\
\hline
\end{tabular}

Quadro 11 - Volume total de correspondências dos Correios (percentuais) por origem e destino conforme regiões do Brasil, 2015.

Fonte: Vice-Presidência de Encomendas dos Correios.

\footnotetext{
${ }^{181}$ Total de objetos postados em 2015 (8,3 bilhões) x percentual da região de destino / população total da região (censo de 2010).
} 
Os dados anteriores também contribuem para desmistificar uma ideia de que o serviço postal é uma atividade do passado, das sociedades tidas como "atrasadas". No Brasil, são justamente as regiões que se modernizaram mais rapidamente aquelas a registrar maior “consumo" per capita de objetos postais, o que pode suscitar a hipótese de que ao avanço das modernizações e o crescimento dos fluxos informacionais corresponde um aumento do fluxo postal. Outra maneira de dizê-lo seria que naqueles lugares marcados pelo meio técnicocientífico-informacional, ao invés de substituição do correio por outros meios, têm-se o aumento do fluxo postal.

A análise dos dados de destino ratifica que a concentração dos fluxos postais não é apenas demográfica, mas denuncia a divisão territorial do trabalho vigente. O Sudeste é a única região a registrar maior postagem que entrega (destino), dado que a qualifica como a única região "postadora" ou "produtora", enquanto as demais seriam "entregadoras" ou “consumidoras". A região Sul é a única das demais a apresentar praticamente um equilíbrio entre fluxos de entrada e saída, o que a coloca, ao lado do Sudeste, em situação privilegiada no país. No âmbito da empresa, essa desigualdade acarreta em maior lucro para as diretorias regionais que registram maior postagem e saldo negativo para aquelas que realizam mais atividades de entrega. As áreas deficitárias conseguem manter o padrão das atividades porque se trata de uma única empresa nacional, que equaliza o balanço das despesas e pagamentos por meio da centralização da administração financeira e contábil.

De fato, a Região Concentrada se caracteriza pelo centrifuguismo dos fluxos postais, enquanto nas demais prevalece um centripetismo, ou seja, maior entrada que saída de correspondências. É assim que no correio se manifesta o papel de comando da Região Concentrada na divisão territorial do trabalho no Brasil. Por isso mesmo, essa região é o nicho de mercado para as empresas privadas que, não conseguindo alcançar todo o território, concentram-se nos lugares que lhes conferem maiores condições de lucratividade. Para o historiador Romulo Valle ${ }^{182}$, do Museu dos Correios,

Um elemento que aumenta a complexidade do caso brasileiro é a grande diferença das condições regionais. Como os custos logísticos no Brasil são extremamente altos e grande parte do território nacional tem uma concentração de entregas bastante rarefeita, as operadoras privadas tendem a concentrar seus esforços nos mercados mais promissores, nos principais eixos de distribuição, deixando de lado aqueles em que a operação é deficitária.

\footnotetext{
${ }^{182}$ Entrevista realizada no Museu dos Correios, Brasília-DF, em março de 2016.
} 
Essa primazia da Região Concentrada, principalmente do Sudeste e mais ainda do estado de São Paulo, foi notada por Gertel (1991, p.159), tendo o autor concluído que "onde as relações de produção são intensas, a densidade das atividades postais se faz presente". A origem privilegiada dos objetos a partir desses lugares coincide com as sedes da maioria das empresas brasileiras, sendo muitas delas grandes clientes dos Correios. Serviços como o comércio eletrônico e o envio de faturas de pagamento pelos operadores de cartão de crédito são entregues em todo o país, mas a postagem tende a ser concentrada, preferencialmente a partir dos lugares dotados de maiores condições de fluidez para as correspondências, como São Paulo. O mesmo se verifica para as remessas de jornais, revistas e impressões de mídia em geral, cuja origem está massivamente concentrada nas duas maiores metrópoles do país.

Observando os dados de 1987 sobre a participação das regiões brasileiras no tráfego postal, verifica-se que houve aumento dessa concentração (Gráfico 5). O Sudeste já era isoladamente a região de onde partiam a maior parte dos objetos postados, posição que foi ainda mais reforçada nas últimas três décadas. Os percentuais de objetos postados no Sul também aumentou, em detrimento da redução da participação das regiões Centro-Oeste e principalmente do Nordeste, esta última tendo reduzido sua participação em mais de um terço nos últimos anos. Assim, somada à situação anterior, verifica-se uma tendência atual de aumento da participação da Região Concentrada no volume de objetos postal, reforçando o seu papel na divisão territorial do trabalho como o espaço da produção dos fluxos, além de sua já assinalada condição privilegiada de fluidez.

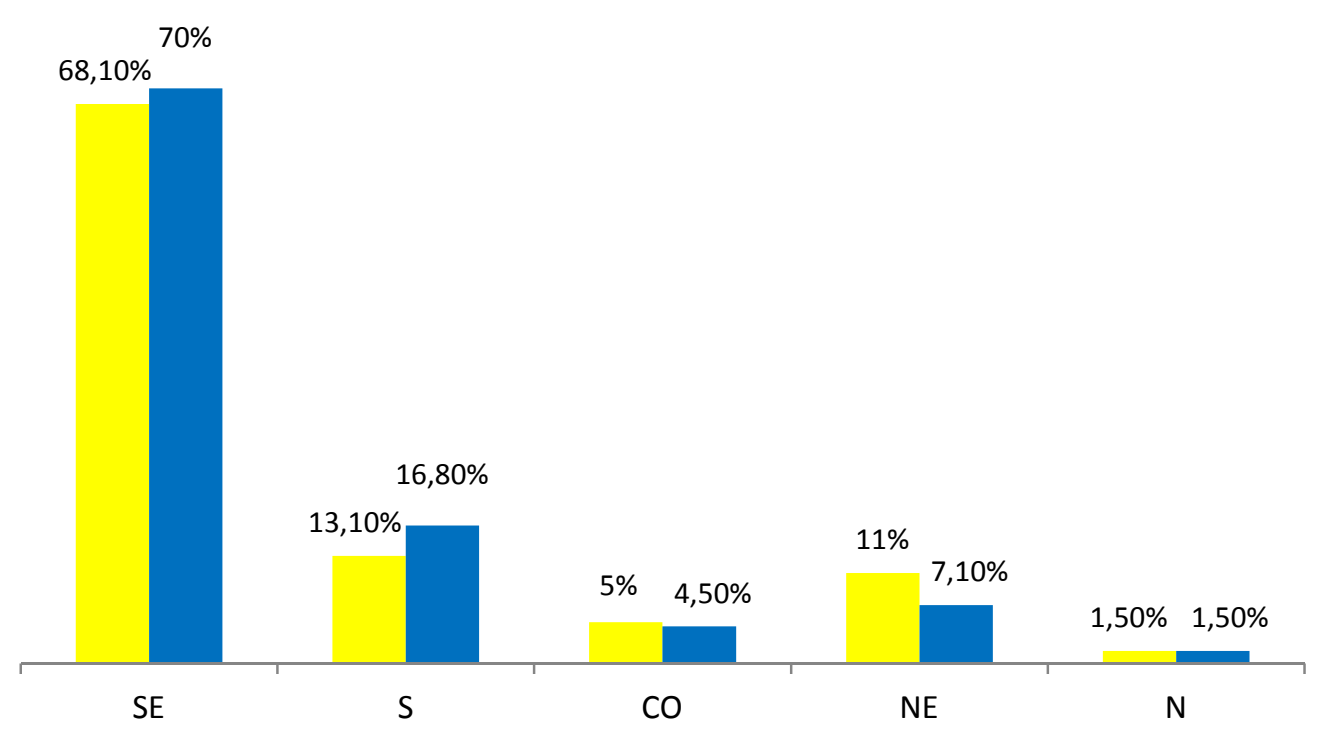

Gráfico 5 - Percentuais do total de objetos postados por região do Brasil em 1987 e 2015.

Fonte: Elaboração própria a partir de dados de Gertel (1991) e Vice-Presidência de Encomendas dos Correios. 
A circulação dos objetos postais no território se faz, no entanto, de maneira contraditória. Ao lado do aumento da concentração das postagens em nível nacional, verificase outra tendência, não menos reveladora: o caráter essencialmente regional dos fluxos. No Brasil, a distância média percorrida por uma correspondência é de 767 quilômetros ${ }^{183}$, valor que não ultrapassa o limite de nenhuma das regiões do país. A distância média é bem mais elevada em países de dimensões territoriais equivalentes ao Brasil: são $1066 \mathrm{~km}$ na China e 2044 km no Canadá. Mesmo em países menores, como Índia, México e Malásia, a distância que uma carta ou encomenda percorre é de 833, 908 e 942 quilômetros, respectivamente. Nesses países há maior desequilíbrio interno entre uma região de postagem e as regiões de entrega.

Em todas as regiões brasileiras, mesmo na Região Concentrada, a maior parte das correspondências postadas não ultrapassa seus limites, ou seja, os fluxos são majoritariamente regionais (Quadro 11). Se 70\% de todos os objetos são postados no Sudeste, mais de dois terços destes destina-se a lugares da própria região. O mesmo dado é válido para as demais regiões, onde mais que a metade das postagens é destinada a cidades próximas.

A centralidade que caracteriza certas cidades médias na rede dos Correios, dentre as quais destacamos Londrina, Bauru, Uberlândia, Juiz de Fora, Feira de Santana e Petrolina, pode estar atrelada a esse caráter regional dos fluxos. A necessidade de centros intermediários para realizar a triagem e encaminhamento para inúmeras cidades pequenas evita a concentração de toda a operação nas metrópoles e capitais. Se os fluxos de longa distância podem ser suficientemente satisfeitos com no mínimo um ponto em cada estado, o mesmo não pode ocorrer com os fluxos regionais, demandantes de maior capilaridade.

Portanto, aos Correios pode ser atribuída uma importância local e regional, cujos serviços integram o território nacionalmente, mas também animam uma teia de articulações intra-regionais no país. Há aqui uma diferença significativa da atuação pontual e restrita das empresas privadas, tanto pelo constrangimento normativo do monopólio estatal brasileiro, quanto por seus próprios interesses. Haveríamos, assim, de considerar as ações dos Correios mais horizontais face às ações verticais ${ }^{184}$ dessas outras multinacionais de correio? É notório

\footnotetext{
${ }^{183}$ Valores divulgados pela UPU para o ano de 2015, a partir do qual são calculadas as taxas de remuneração das despesas de transporte aéreo no interior do país de destino, no caso das remessas internacionais. O documento "taxa de remuneração das despesas de transporte aéreo no interior do país de destino para 2016" pode ser acesso pelo endereço eletrônico da instituição em http://www.upu.int/en.html

${ }^{184}$ No sentido atribuído por Milton Santos ([1996] 2012b, cap.12) às horizontalidades e verticalidades. As primeiras corresponderiam a "pontos que se agregam sem descontinuidade", como na concepção tradicional do
} 
que em muitas áreas precárias como em favelas de grandes cidades, onde apesar de sua localização na metrópole são espaços periféricos e não contam com os serviços de entrega das multinacionais, os Correios mantêm uma regularidade na entrega, o que pode ser entendido como um diferencial face à escassez de serviços públicos nesses lugares (Fotografia 18). Mesmo nas áreas centrais das grandes cidades, a empresa vem adotando estratégias inovadoras de entrega, a exemplo do "carrinho" utilizado em logradouros com volume significativo de entregas, mas inacessíveis para veículos automotores (Fotografia 19).

Aquilo que Carneiro (2006) apresenta como "uma nova visão do setor postal brasileiro" não tem nada de novo; trata-se apenas da repetição de uma receita defasada de controle privado sobre os serviços públicos, já utilizada para o correio na Europa desde o século XIII (BRAUDEL, [1966] 1983). A autora trata o correio numa dimensão abstrata, desconsiderando a importância real de uma empresa pública para os lugares não lucrativos para o mercado, como já demonstrado no caso dos EUA (Capítulo 2).

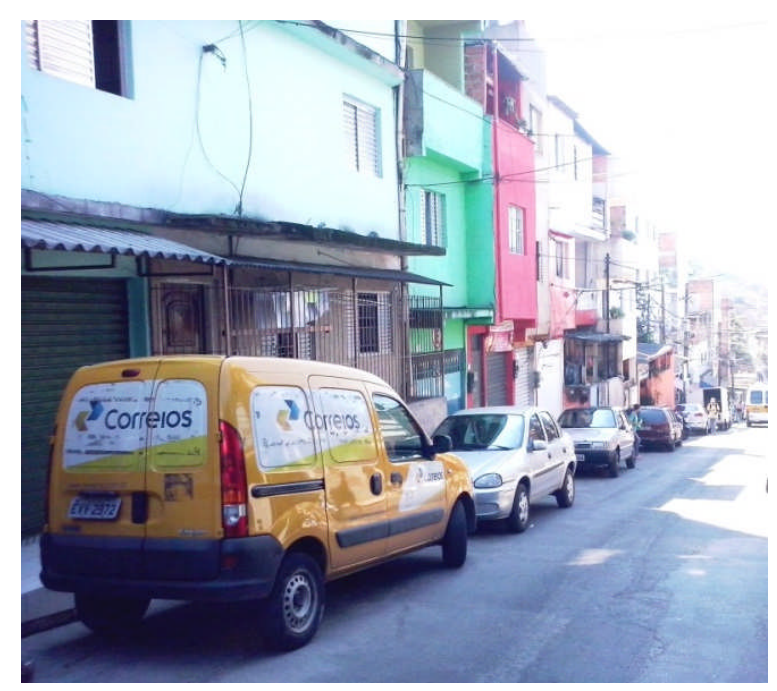

Fotografia 18 - Veículo de entrega dos Correios na favela de Paraisópolis, zona sul de São Paulo. Fonte: Trabalho de campo realizado em abril de 2016.

Foto: Igor Venceslau.

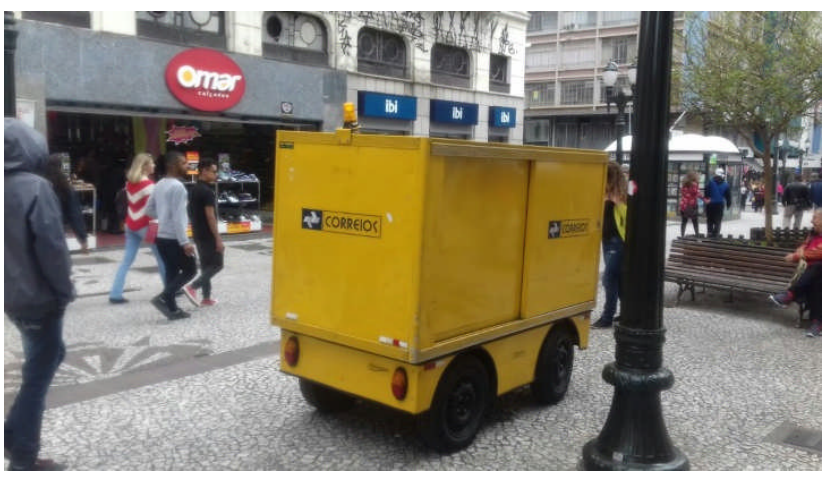

Fotografia 19 - Carrinho de entrega dos Correios em calçadão da cidade de Curitiba-PR. Foto: Wagner Nabarro.

Estudando a responsabilidade social de várias empresas, Pereira (2007) considera que a característica do trabalho intensivo em mão-de-obra nos Correios consistiria exatamente na força horizontal peculiar à empresa:

termo região. Já as verticalidades seriam constituídas por "pontos no espaço que, separados uns dos outros, asseguram o funcionamento global da sociedade e da economia”. Ver também Santos ([2000] 2011). 
Trata-se de uma relação cotidiana com a população que não pôde ser mecanizada [a entrega pelos carteiros], e que garantiu que hoje, com unidades dispersas por todo o país, esta instituição possa ser fortemente identificada com a formação socioespacial brasileira, gozando de prestígio e de legitimidade em relação às suas ações (PEREIRA, 2007, p.144).

Essa característica mais horizontal contrasta com a ação mais concentrada de outras empresas, embora mesmo na topologia dos Correios seja possível encontrar evidências da concentração das atividades econômicas e as desigualdades socioespaciais. Por isso ainda pode-se falar, com Walsh (1992), em correio como human express (expresso humano), pois apesar das novas tecnologias a atividade de entrega depende do trabalho manual dos carteiros.

\subsubsection{A centralidade de São Paulo}

O volume de operações postais do estado de São Paulo é tão expressivo que resulta na divisão pelos Correios de duas diretorias regionais, uma metropolitana e outra do interior, esta última com sede em Bauru. Os dados referentes à diretoria metropolitana revelam o peso da metrópole paulista para o país: o conjunto de 61 municípios da Baixada Santista, Litoral Norte, Vale do Paraíba e Região Metropolitana de São Paulo (RMSP) é responsável por realizar diariamente a postagem de 19 dos 33 milhões de objetos entregues todos os dias pelos Correios no Brasil, sendo que somente 6 milhões são entregues na própria região. Essa logística mobiliza um contingente de quase 20 mil trabalhadores alocados nos 490 pontos de atendimento e nos 413 pontos de distribuição ${ }^{185}$.

O volume dos fluxos per se já atribui a São Paulo uma posição privilegiada dentre todas as demais cidades brasileiras. No mais, há vários elementos que corroboram para essa centralidade da metrópole paulista: uma centralidade informacional, sendo o lugar a partir do qual se constitui uma racionalidade espacial do CEP; uma centralidade de referência de fluidez territorial, a partir da qual se definem os prazos de entrega para todo o país; uma centralidade operacional nacional, sendo o grande $h u b$ aéreo e rodoviário, além de possuir a maior capacidade instalada de triagem de objetos; e uma centralidade operacional internacional, como grande nó de articulação dos serviços expressos para outros países. Desta maneira, São Paulo se afirma como "grande relê nacional de distribuição" (HUERTAS, 2013, p.221), inclusive para o correio.

\footnotetext{
${ }^{185}$ Dados coletados em trabalho de campo realizado no CTE Jaguaré, em São Paulo-SP, em março de 2015.
} 

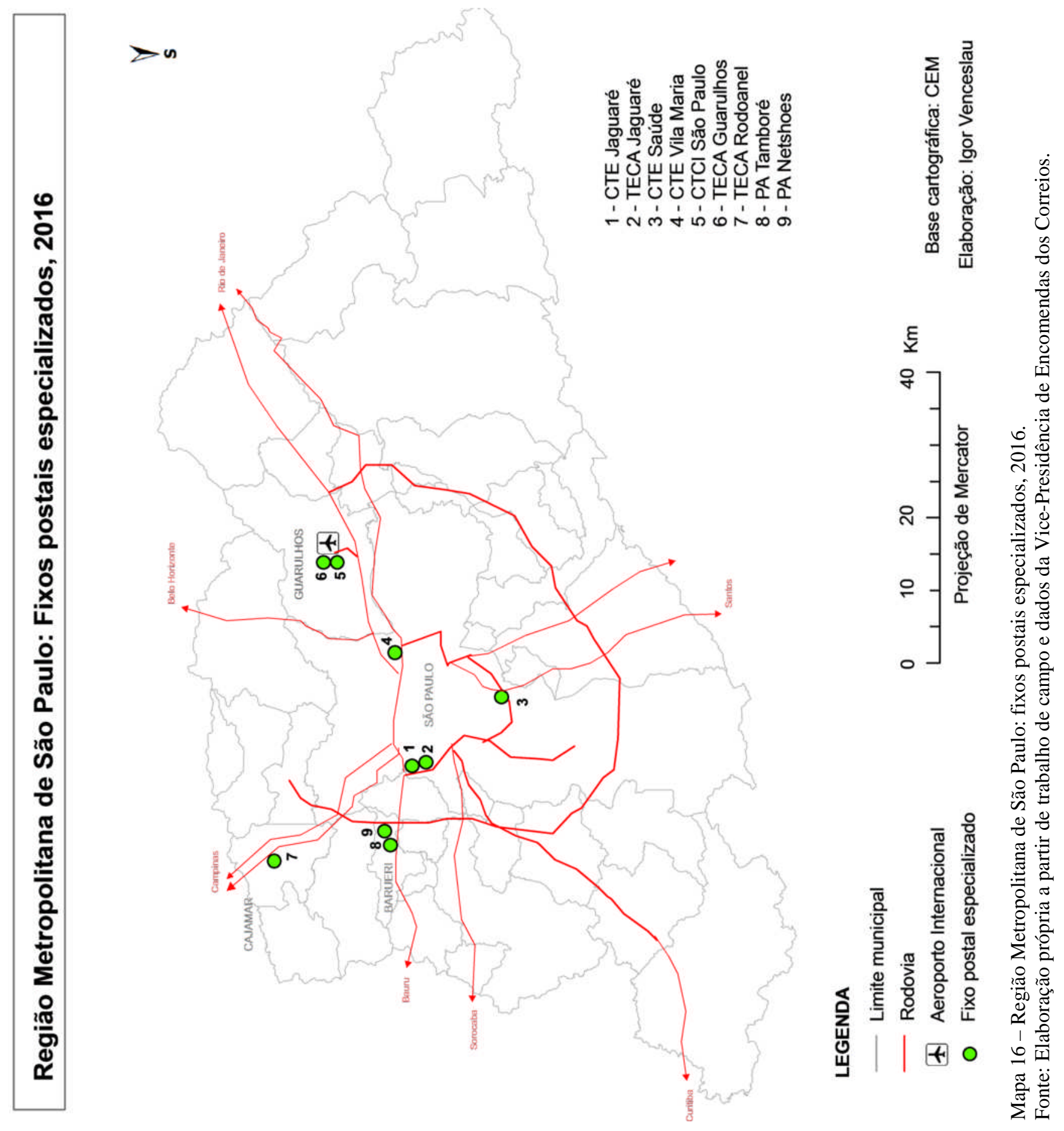
Essa centralidade se realiza na escala local por meio de uma divisão intraurbana ou intrametropolitana do trabalho (Mapa 16). São Paulo é a única metrópole a reunir nove fixos postais especializados, que contribuem para assegurar a sua posição primaz. No município de São Paulo, mais populoso, estão três centros de tratamento automatizados que realizam a triagem e o encaminhamento de correspondências conforme uma regionalização de áreas específicas de atuação: o CTE Jaguaré recebe e encaminha objetos de toda a porção oeste da RMSP, que além da zona oeste de São Paulo inclui municípios como Osasco, Barueri e Cotia, entre outros (Fotografia 20); o CTE Saúde responde pela porção sul, que inclui parte da capital e a região do $\mathrm{ABC}^{186}$; e o CTE Vila Maria recebe/encaminha para as porções norte e leste, que também inclui Guarulhos, Mogi das Cruzes, entre outros.

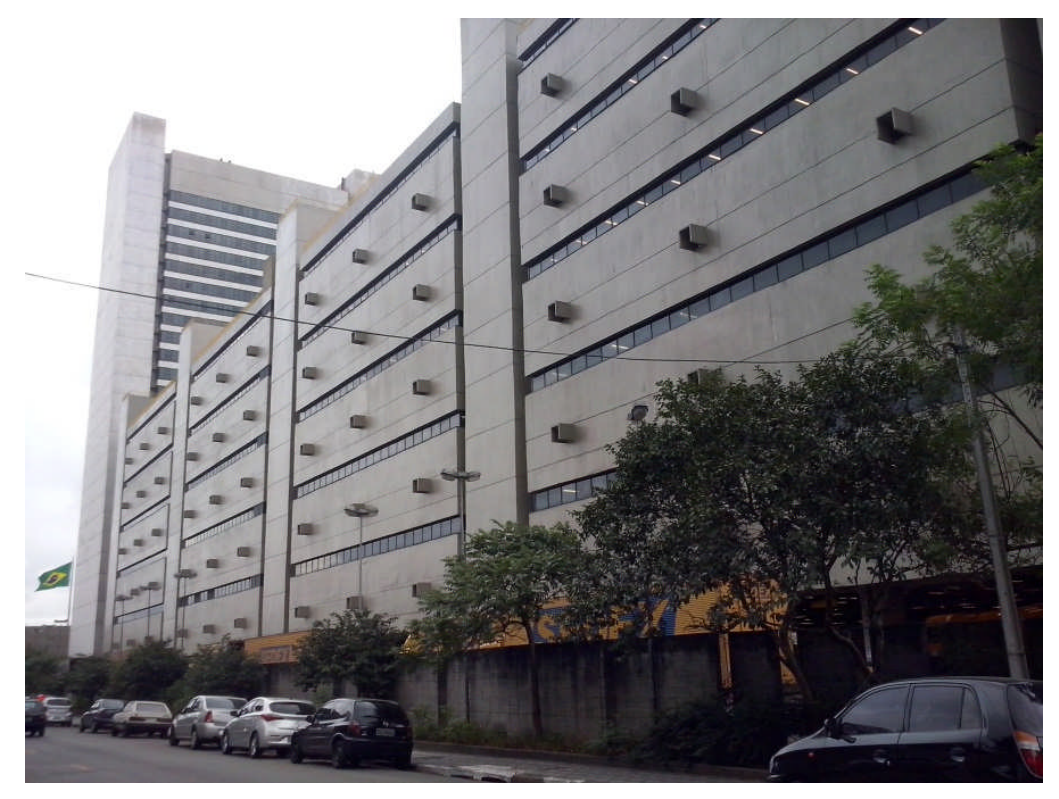

Fotografia 20 - CTE Jaguaré, na zona oeste de São Paulo. Ao fundo, edifício-sede da diretoria São Paulo Metropolitana dos Correios.

Fonte: Trabalho de campo realizado em março de 2015.

Foto: Igor Venceslau.

Três terminais de carga realizam o transbordo de carga já consolidada pelos CTEs: o TECA Jaguaré, no próprio município de São Paulo, para transporte rodoviário; o TECA Rodoanel, em Cajamar ${ }^{187}$, para o transporte rodoviário; e o TECA Guarulhos, localizado no aeroporto internacional, exclusivo para a carga aérea do SEDEX. Também no aeroporto de Guarulhos está o centro de tratamento de correio internacional (CTCI) de São Paulo.

A metrópole paulista é a única a dispor de um fixo postal bastante específico - o Posto de Atendimento Avançado (PA). Criado para atender a demanda dos grandes clientes dos Correios, ou seja, as empresas de comércio eletrônico, os PAs agilizam a circulação das

\footnotetext{
${ }^{186}$ Região formada pelos municípios de Santo André, São Bernardo do Campo e São Caetano do Sul. Eventualmente são incluídos nessa regionalização outros municípios, como Diadema e Mauá.

187 O terminal recebe o nome de "rodoanel" pela facilidade de acesso ao Rodoanel Mário Covas, embora se localize às margens da Rodovia Anhanguera.
} 
encomendas por reunir num só espaço os procedimentos de postagem e encaminhamento, sempre de maneira exclusiva para as empresas cadastradas. De lá os objetos são triados e transportados em unitizadores exclusivos diretamente para CTE Jaguaré, que possui um terminal de cargas no mesmo local ${ }^{188}$. Há apenas duas dessas unidades, ambas localizadas no município de Barueri, que se caracteriza pela concentração de galpões de distribuição dessas empresas na região conhecida como Alphaville/Tamboré:

- PA Tamboré: atendimento exclusivo para clientes como Saraiva, Adidas, Nova Ponto Com, Decathlon, B2W (Americanas, Submarino, Shoptime);

- PA Netshoes: única unidade dos Correios localizada dentro do cliente, um contrato de exclusividade com a empresa de $e$-commerce de produtos esportivos Netshoes.

Encontra-se em andamento negociações entre os Correios e a empresa de e-commerce de vestuário Dafiti para a criação de um PA dentro da empresa, semelhante à unidade da Netshoes. Outro empreendimento em construção é o futuro Centro de Operações Logísticas (COL), que será instalado em Cajamar junto ao TECA Rodoanel e abrigará vários clientes corporativos cujas atividades são intensivas em serviço postal.

Os fixos postais especializados são exigentes de fluidez territorial. A escolha dessas localizações na cidade decorre de estudos previamente realizados, com o intuito de definir os pontos a partir dos quais o território, tanto dentro da metrópole quanto fora dela, pode ser acessado com maior velocidade pelos veículos dos Correios ${ }^{189}$. Não por acaso, todos os fixos postais especializados da RMSP foram estabelecidos às margens das principais rodovias de acesso à metrópole, ou mesmo na encruzilhada de mais de uma delas: as Marginais Tietê e Pinheiros, a Rod. Imigrantes, a Rod. Castelo Branco, o Rodoanel, etc. Para Lencioni (2010), as redes materiais como rodovias e autopistas, bem como as redes imateriais, diferenciam a região de São Paulo do restante do território brasileiro, a maior expressão do que a autora denominou de "metamorfose do urbano" no período atual.

Com os papeis que cumpre na divisão territorial do trabalho, São Paulo afirma-se como "o centro de comando da economia e do território nacional" (BERNARDES SILVA, 2011, p.57), o que é verificado inclusive no que se refere aos serviços mais banais como o correio. Para este, as condições de fluidez para os fluxos materiais e informacionais

\footnotetext{
${ }^{188}$ Para o faturamento, a máquina de triagem do CTE concilia informações do objeto (peso, medida, etc.) com aquelas adicionadas nos PAs por meio do Sistema de Conferência de Cargas e Encomendas (SCCE), disponível em ambas as unidades operacionais.

${ }^{189}$ Segundo informações adquiridas em trabalho de campo no CTE Jaguaré, em São Paulo-SP, realizado em março de 2015, há estudos de viabilidade operacional solicitados pelos Correios a empresas de consultoria especializada, a partir dos quais são definidas as localizações das unidades da empresa.
} 
proporcionadas pela metrópole paulista se tornam na atualidade um diferencial e um imperativo.

\subsection{Estado-território-mercado e planejamento: de lugares para a logística a uma logística para os lugares}

Um serviço público de correio, tal qual o adotado no Brasil, coloca como central a questão sobre o planejamento do território. No bojo das tensões entre Estado e mercado, além da circulação das coisas está em jogo a integração territorial, a conexão dos lugares e a constituição de um elo de articulação material entre as empresas, instituições e a população em geral. Desta maneira, o território manifesta as consequências desse conflito, como mediação e condição essencial para a realização das ações concretas desses agentes na sociedade. A problemática levantada por Mattelart (1994, p.16) duas décadas atrás continua a ecoar e desafiar as investigações por uma resposta atual: "Entre Estado e setor privado, quem deve controlar a circulação da informação, a implantação e o funcionamento das redes de comunicação à distância? Quem está autorizado a utilizar os novos serviços?”.

Para o planejamento territorial há um desafio que se coloca: é possível estabelecer uma logística para os lugares, que favoreça o suprimento das necessidades locais e atenda às demandas da população? No caso da logística empresarial, o uso corporativo do território produz antes lugares para a logística, como no vale do Ohio-Mississippi (EUA), do que uma logística para os lugares. Que ações dos Correios apontam para uma logística que pode contribuir na constituição de solidariedades entre os lugares?

\subsubsection{O correio como infraestrutura do território}

Queremos aqui resgatar a noção de correio como infraestrutura do território, que foi apenas apontada no trabalho de Gertel. Nesse sentido, o autor considera que "o serviço postal é um fator da infraestrutura de uma unidade territorial, participando do desenvolvimento econômico, social e cultural das nações" (GERTEL, 1991, p.114). Desta maneira, buscamos apontar em que medida a rede logística dos Correios é uma componente territorial determinante nas ações de diversos agentes sociais.

Para Dupuy (1993), nas réseaux usuels (redes usuais), que incluem aquelas utilizadas para o fornecimento de água, eletricidade, gás, mas também as redes de transporte, telecomunicações e o correio, por fornecerem serviços e não bens, os preços praticados 
geralmente não são estabelecidos por demanda de mercado, mas pertencem a um domínio de tarifação pública. Para o autor, o poder público tem um papel importante na tutela de redes desse tipo, tendo sido historicamente assumidas pelo Estado principalmente por razões como segurança, equidade e estratégias de soberania.

Em primeiro lugar, é preciso destacar que os Correios importam para a atuação das próprias empresas multinacionais concorrentes. As empresas privadas de correio, além do constrangimento normativo brasileiro, ainda se deparam com a materialidade do território, no qual elas oferecem seletivamente seus serviços apenas nos lugares dotados de maior fluidez, valendo-se da cooperação com os Correios para garantir a eventual entrega de correspondências em outras porções do território. A atuação maior na Região Concentrada e em alguns pontos (principalmente metrópoles) de outras regiões demonstra a correspondência com a própria difusão seletiva do meio técnico-científico-informacional, dado que as atividades de logística são intensivas em informação e tecnologia.

A capilaridade da rede já instalada no território permite a execução de operações postais especiais. No ano de 2016, os Correios foram o operador logístico oficial dos Jogos Olímpicos do Rio de Janeiro, ação que destoa da tendência de parcerias entre o Comitê Olímpico Internacional (COI) e a empresa estadunidense UPS. Na decisão, influenciou o monopólio estatal sobre o segmento de mensagens, porque apesar do serviço de encomendas ser liberado para a execução por outra empresa, a logística para os jogos também necessitava de serviços como cartas expressas, telegramas, etc. Também a capacidade instalada dos Correios ultrapassa e muito a de qualquer outra empresa nacional ou estrangeira. Sob o slogan “a logística é nossa!", a empresa pública brasileira foi primordial para o evento esportivo desde o início: mais de 1 milhão de encomendas contendo os ingressos vendidos foram entregues diretamente no endereço dos compradores em todo o país meses antes do início dos $\operatorname{jogos}^{190}$. A operação foi concluída com mais de 30 milhões de objetos entregues durante os jogos, incluindo desde a bagagem pessoal dos atletas e mobiliário para suas instalações até materiais utilizados diretamente nos jogos como bolas, remos e alambrados. Para tanto, a empresa utilizou suas agências e centros de distribuições já existentes na cidade do Rio de Janeiro, além de contar com um efetivo de mais de dois mil funcionários. Uma frota de 170 caminhões percorreu cerca de 1,2 milhões de quilômetros dentro da metrópole fluminense ou articulando outros lugares do país, principalmente com o aeroporto de Guarulhos, em São Paulo.

\footnotetext{
190 Segundo informações da empresa disponibilizadas em seu endereço eletrônico oficial em
} https://www.correios.com.br/para-sua-empresa/logistica-integrada/rio-2016. 
Para análises desatentas à dimensão geográfica do correio, o monopólio postal poderia ser entendido como a possibilidade de instituir um "território postal único". No entanto, as desigualdades e contradições do espaço determinam os serviços postais, eliminando qualquer possibilidade de falar em homogeneização.

No centro de uma topologia dos Correios está a metrópole de São Paulo, aquela dotada de maior fluidez e onde se localizam os fixos postais mais especializados, nó de uma rede aérea e rodoviária que articula todo o território brasileiro e de onde também se forma a lógica dos prazos nessa logística. São Paulo assume o comando operacional dos Correios, ainda que a função administrativa esteja outorgada a Brasília. De São Paulo é possível acessar o território nacional com maior velocidade, por isso aí se encontram todos os serviços mais expressos e, na encruzilhada dos fluxos, ampliam-se as possibilidades de conexão com o país. Assim, a metrópole paulista se torna lugar privilegiado para a localização de empresas de $e$ commerce, pois estas são intensivamente dependentes dos serviços de entrega rápida e de uma logística eficiente, potencializando o uso do território brasileiro para essas empresas.

Assim, o correio pode ter se tornado um agente essencial para uma segunda unificação do mercado nacional, desta vez sob a forma do comércio eletrônico. Inicialmente as agências dos Correios funcionavam como vitrines de catálogos para vendas via postal, um serviço conhecido como Reembolso Postal, hoje pouco utilizado. Nesse tipo de comércio à distância protótipo do e-commerce, os catálogos de empresas como a Hermes ${ }^{191}$ eram expostos nas agências e o cliente postava de volta o catálogo com a designação do que desejava adquirir. Dentro de alguns dias chegava à casa do destinatário um aviso para retirar a caixa com os produtos na agência dos Correios, onde também era realizado o pagamento pela compra. $\mathrm{O}$ mesmo serviço foi amplamente utilizado no oferecimento de cursos à distância ${ }^{192}$ em todo o país, como os do Instituto Padre Reus, que ainda levam até as populações de todos os municípios materiais didáticos comprados por meio dos catálogos divulgados nas agências, com posterior entrega de certificados. Atualmente o serviço de Reembolso Postal foi amplamente substituído pelas compras virtuais realizadas no próprio domicílio do cliente, inicialmente por telefone e hoje ainda mais com a difusão do acesso à Internet. O serviço postal, contudo, continua sendo a via mais utilizada para fazer esses produtos chegarem até o endereço do comprador, criando uma ampla dependência entre as empresas de e-commerce e o correio, de um lado, e dinamizando o segmento de encomendas postais, de outro.

\footnotetext{
${ }^{191}$ O nome da empresa é alusivo ao deus da velocidade e da comunicação na mitologia grega.

192 Desde a década de 1970, pelo menos, tornou-se possível à população brasileira adquirir nas agências dos Correios os materiais para os cursos mais variados: supletivos para ensino fundamental e médio, culinária, eletricista, cabeleireiro, instrumentos musicais, técnico em informática, entre muitos outros.
} 
As grandes empresas de comércio eletrônico podem ser incluídas naquilo que $\mathrm{M}$. Santos ([1979] 2004) denominou de "circuito superior da economia urbana", pois suas atividades são intensivas em capital, tecnologia e organização. Para elas, o tempo de entrega se tornou um diferencial competitivo e a localização privilegiada no território - a metrópole paulista - permite utilizar o serviço postal com maior velocidade. Contudo, é possível notar que as empresas do "circuito inferior", intensivas em trabalho e com baixo grau de organização, de tecnologia utilizada e de capital, também se valem dos Correios em diversas situações. Para as empresas do circuito inferior, bem como para as do circuito superior marginal, o correio pode significar um elemento dinamizador das suas atividades, seja para o abastecimento de produtos para a venda, seja para a venda desses mesmos produtos (Fotografia 21). No primeiro caso, as compras online nas empresas de e-commerce permitem o abastecimento do comércio local de itens que não estavam disponíveis em certas cidades pequenas há alguns anos. Também hoje é possível a compra diretamente de empresas da China, com entrega na porta pelos Correios, principalmente de artigos eletrônicos como aparelhos de celular, pen drives, laptops, etc.

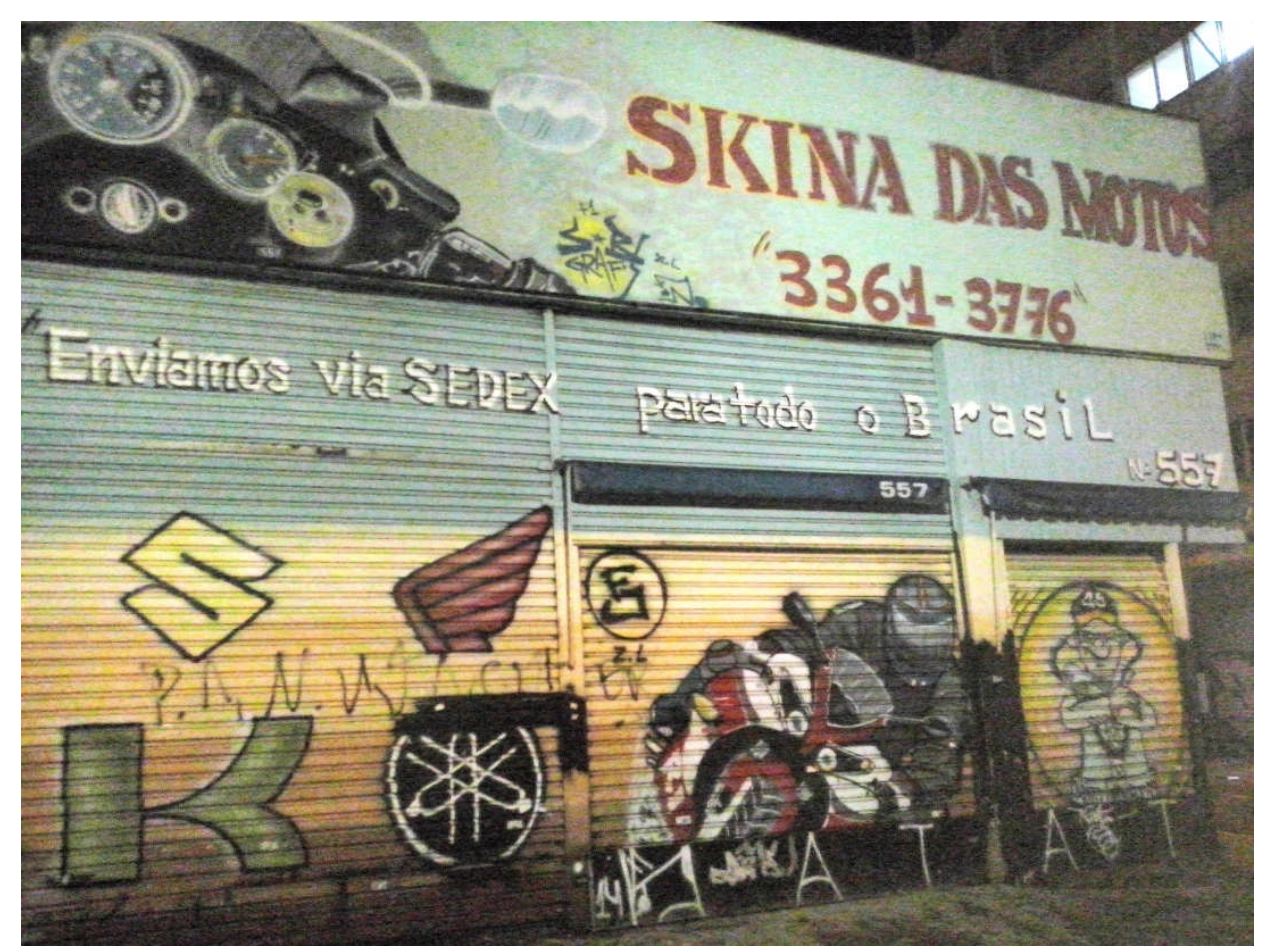

Fotografia 21 - Loja de peças para motocicletas com entrega via SEDEX para todo o Brasil, localizada no centro da cidade de São Paulo.

Fonte: Trabalho de campo realizado em maio de 2016.

Foto: Igor Venceslau

Essas pequenas empresas também utilizam o serviço postal para eventuais vendas à distância. Pelo correio são enviados artesanatos, confecções, CDs, peças para aparelhos 
eletrônicos ou veículos, dentre outros. Nesse sentido, merecem menção duas plataformas que abrigam vendedores autônomos ou pequenas empresas na Internet: o Mercado Livre e a Estante Virtual. No primeiro caso, os vendedores anunciam qualquer produto, novo ou usado, e os compradores solicitam os produtos, que são enviadas quase sempre pelos Correios. Já a Estante Virtual atua como mediadora entre uma infinidade de pequenos sebos que não dispõem de meios para manter um website para a venda de livros e os seus respectivos consumidores, num mercado que, pela entrega via postal, se ampliou para todo o país.

Juntamente com a geógrafa Bertha Becker (2007), reiteramos a necessidade de pensar uma "logística do pequeno", ou ainda uma logística do Estado para o pequeno, aquela que favoreça também os esquecidos pelo mercado e pelas lógicas empresariais que se beneficiam das infraestruturas e dos valores socialmente produzidos. Desta maneira, não é possível considerar a superação do correio como serviço público para assumi-lo apenas pela noção de utilidade econômica, como quer Xavier (2007) ao questionar se somente o Estado seria capaz de realizar ações de interesse coletivo. Além de não demonstrar essa atuação pelas empresas privadas, a autora endereça equivocadamente a questão como "existe o monopólio da União?”, já que a retórica não deveria ser existencial e sim política, perguntando-se por que, para que e para quem serve o monopólio. Nos Correios, além do segmento das encomendas mais baratas, a permanência de um serviço como a "carta social"193 aponta nessa direção. É mister assegurar o acesso aos serviços mais básicos e às redes de todos os tipos por parte das pequenas empresas, das pequenas cidades, das regiões mais remotas, das pessoas mais pobres - não porque podem pagar pelos custos dos serviços e se configuram enquanto potencial mercado consumidor, mas como um direito, devidamente assegurado pelo Estado aos cidadãos.

\subsubsection{Os Correios para além do serviço postal}

Além das tradicionais atividades relacionadas ao correio, as agências dos Correios cumprem uma função importante como fixos geográficos a partir dos quais se torna possível uma gama de outras ações. De acordo com Romulo Valle ${ }^{194}$, os Correios como única instituição presente em todos os municípios brasileiros faz com que sua capilaridade seja "um

\footnotetext{
${ }^{193}$ Serviço de envio de cartas com valor simbólico de $\mathrm{R} \$ 0,01$ (um centavo). A carta social está disponível em todas as agências dos Correios, possuindo os mesmos elementos e sendo submetida aos mesmos procedimentos logísticos dos demais objetos, inclusive a entrega domiciliar ao destinatário. Para o seu envio, devem ser cumpridos os seguintes requisitos: carta manuscrita; remetente e destinatário sejam pessoas físicas; peso de até $10 \mathrm{~g}$; envio máximo de cinco unidades por remessa.

${ }^{194}$ Entrevista realizada no Museu dos Correios, Brasília-DF, em março de 2016.
} 
elemento diferencial quando se pensa na implementação de políticas públicas”. Nesse sentido, a execução dessas políticas encontra na rede constituída pelos Correios um elemento da materialidade do território que permite a sua concretização. O trabalho de Pereira (2007) revelou que isso não se deve apenas ao dado da topologia da empresa (técnico), mas reside no fato mesmo de sua natureza como empresa estatal (político), que unidas essas condições resultam em benefícios para os lugares:

O fato dos Correios serem, simultaneamente, uma empresa com ações dispersas e também uma empresa estatal, permite que parte considerável de sua atuação social consista na utilização da rede logística do serviço postal no auxílio da implementação de políticas públicas (PEREIRA, 2007, p.145).

Desta maneira, o correio público, para além de suas funções tradicionais, cumpre um papel importante como um "braço" logístico do Estado, como também apontado por Mattelart (1994) para outros países. No caso brasileiro, a dimensão territorial e as desigualdades regionais sinalizam para o reforço dessa importância do correio, que ultrapassa em muito a simples responsabilidade social (econômica, legal, filantrópica e ética) estudada por Martins (2007). Portanto, quais seriam as políticas públicas nas quais a participação dos Correios é condição sine qua non para a sua execução? E de que maneira a atuação dos Correios se constitui no fomento à criação de solidariedades no território?

Em primeiro lugar, os Correios participam ativamente da elaboração de um dos ingredientes básicos da cidadania: a criação de endereços. É a empresa postal pública que, juntamente com as prefeituras municipais, formaliza os logradouros, concedendo o número respectivo de CEP e permitindo aos moradores utilizarem um endereço formal. A criação do endereço pode ser entendida como a outorga da cidadania, pois só a partir de então podem ser solicitados serviços básicos de água, saneamento e eletricidade, abertura de conta bancária, cadastramento em programas sociais, entre outros. Essa atribuição dos Correios ultrapassa suas funções básicas de provedor dos serviços postais para alcançar um patamar de agente ativo na organização e regulação do espaço.

Outro elemento da cidadania é, no Brasil, a produção do documento denominado Cadastro de Pessoa Física (CPF). Inicialmente o documento era emitido somente nas agências da Receita Federal e do Banco do Brasil, passando em seguida a ser emitido em todas as agências próprias dos Correios, ação que ampliou o alcance do serviço para a totalidade dos municípios do país. É relevante ressaltar que além de atender aos serviços de emissão, regularização e pedidos de segunda via do CPF, a empresa também realiza a entrega domiciliar do documento, assegurando o seu acesso universal. 
Os Correios também emitem certificados digitais no Brasil. A certificação digital é um documento que autoriza transações em ambiente virtual que demandam identificação clara do usuário, como o comércio eletrônico, a assinatura de contratos, governo eletrônico e algumas operações bancárias. Uma vez que esses documentos funcionam como identidade virtual, sua emissão somente é realizada por órgãos de autoridade certificadora ou uma autoridade de registro por ela designada. No Brasil, os Correios são uma autoridade de registro para a criação de certificados digitais dos tipos $e$-CPF (pessoa física) e $e$-CNPJ (pessoa jurídica) em todo o território nacional ${ }^{195}$.

Os Correios também participaram ativamente no Programa Fome Zero, iniciado pelo governo do Presidente Lula (2003-2010) no ano de 2003. Durante a sua execução, as agências postais de todas as cidades foram os postos de arrecadação e entrega de mais de 615 toneladas de alimentos ${ }^{196}$, cuja logística de distribuição também era realizada pela empresa desde a escala nacional até a escala local. Como o programa visava atingir os lugares e a população mais pobres do país, nenhum outro operador logístico dispunha de tamanha capilaridade e de uma infraestrutura montada que permitisse, com prontidão, atender aos objetivos estabelecidos.

A promulgação das resoluções normativas 2640 (de agosto de 1999) e 2707 (de maio de 2000) do Banco Central, instituindo a figura do "correspondente bancário" no cenário nacional foi o marco inicial que permitiu, a partir de então, a criação da marca Banco Postal $^{197}$, autorizando aos bancos utilizarem as agências dos Correios na prestação de serviços bancários básicos à população. Segundo Dias (2009, p.12), o correspondente bancário é uma espécie de "objeto híbrido que combina serviço, tecnologia de comunicação e produto, e que viabiliza uma expansão territorial e social sem precedentes das redes bancárias no território brasileiro" (grifos da autora). Se de um lado essa medida foi de suma importância para levar os serviços bancários àqueles pontos do território que não eram atraentes para a abertura de agências tradicionais, por outro contribuiu para a ampliação do lucro dos bancos. Nos dez primeiros anos (2002-2011), o banco privado nacional Bradesco compôs a parceria com os Correios, levando o banco, na época, a utilizar-se da propaganda de presença em todo o território nacional. É um discurso do território, mas também uma ação no território,

\footnotetext{
195 Para mais informações sobre os certificados digitais, consultar https://www.correios.com.br/paravoce/compra/certificados-digitais.

${ }^{196}$ Conforme dados de Correios (2016).

${ }^{197}$ No mundo, o oferecimento de serviços bancários e financeiros por agências de correio não é novidade: surge na Inglaterra há mais de 100 anos e hoje pode ser encontrado em países como o Japão, França e Alemanha, sendo sua criação estimulada pela Organização das Nações Unidas e pelo Banco Mundial (CORREIOS, 2016).
} 
imprescindíveis para o sucesso do capitalismo na contemporaneidade, aliado inclusive às normatizações e instituições do Estado, como no exemplo em tela. Desde 2012, todavia, o Banco do Brasil substituiu o Bradesco na segunda fase do Banco Postal, desta vez duas instituições públicas dão seguimento ao projeto de Estado de levar os serviços bancários básicos a todos os municípios do país ${ }^{198}$.

O Brasil assistiu, portanto, a uma transformação qualitativa dos Correios em um correspondente bancário. Mas por que os Correios? Novamente, essas ações estão amparadas no caráter geograficamente difuso dos fixos postais, sobretudo as agências próprias dos Correios. A capilaridade é a característica que distingue a empresa de qualquer outra instituição pública ou privada no Brasil, mesmo se comparada aos maiores bancos (que já possuem um grande número de agências), a única que poderia levar a cabo essa iniciativa do Estado num prazo imediato, com tamanho êxito. Somado a essa característica, Contel (2006, p.251) atentou para o fato de que "sendo as agências dos Correios especializadas na circulação de informações, podem ser consideradas como um circuito geográfico privilegiado para a instalação de uma rede de prestação de serviços bancários”. Ao invés de construir agências ou criar outras estratégias, uma parceria entre o setor bancário e os Correios permitiu, quase que instantaneamente, levar os serviços aos municípios não atendidos. $\mathrm{O}$ estudo empreendido por Medeiros (2013) no estado de Alagoas revelou que a totalidade das agências dos Correios operam como correspondente bancário, elevando sobremaneira a presença do Banco do Brasil no território. Como toda ação sob o capitalismo guarda a sua propriedade de ser contraditória, não existe somente o interesse do Estado em expandir os serviços bancários à população. Os interesses de mercado das instituições bancárias, principalmente face à impelente concorrência a que foram expostas com a entrada de grandes conglomerados financeiros no país, atuaram juntamente com os objetivos estatais para melhorar o acesso e, consequentemente, a qualidade de vida da população antes marginalizada dos serviços bancários.

Também em parceria com o Banco do Brasil, os Correios executam desde 2003 o programa Exporta Fácil, por meio do qual é possível realizar exportação de remessas de até 30 quilogramas de qualquer lugar do país para todo o mundo. Com esse serviço, as agências

\footnotetext{
${ }^{198}$ Para a surpresa de todos, inclusive do próprio Banco Bradesco que lograva a renovação do contrato, o Banco do Brasil venceu o leilão com o lance no valor de $\mathrm{R} \$ 2,3$ bilhões, expandindo virtualmente sua presença de pouco mais de 3000 para a quase totalidade dos municípios brasileiros. Qual seria o interesse do Estado, duplamente, em garantir a expansão de um banco público por meio de uma outra empresa pública? Podemos afirmar que o diferencial do Banco do Brasil nesta segunda fase (já que a mesma instituição participou do primeiro edital) reside na estratégia de um governo diferente daquele de 2001, que havia realizado as privatizações anteriores?
} 
dos Correios se transformam em recintos alfandegários ${ }^{199}$ da Receita Federal, com todo o desembaraço aduaneiro realizado no próprio local. O serviço está disponível para pessoa física ou jurídica, beneficiando principalmente micro empresas, cooperativas e autônomos.

Os Correios também funcionam como uma espécie de operador logístico para o sistema judiciário brasileiro. Todos os documentos trocados entre os cartórios civis, comarcas, fóruns e tribunais seguem via postal, aumentando significativamente a demanda pelo serviço de carta registrada. Além disso, diante de qualquer julgamento no Brasil, somente o Aviso de Recebimento dos Correios é considerado como comprovação válida de troca de mensagens entre os sujeitos de direito, incluindo pessoas físicas e jurídicas.

No Brasil, a votação para eleições em todas as instâncias - municipal, estadual e federal - passou a ser realizada eletronicamente desde o ano 1996. A automatização com o uso da urna eletrônica permitiu que a votação se realizasse ao mesmo tempo em todo o país, e ainda agilizou a divulgação do resultado para apenas alguns minutos ou horas a partir do encerramento do trâmite. Mas como as urnas chegam, em sigilo e segurança, a todos os lugares ao mesmo tempo? Próximo às eleições, uma grande operação logística mobilizada entre o Tribunal Superior Eleitoral e os Correios faz com que a votação eletrônica brasileira seja possível por meio da coordenação, amplamente sigilosa e veloz, da distribuição dos equipamentos aos locais de votação. É válido ressaltar que também os demais materiais, como formulários, placas identificadoras e todos os materiais necessários para o dia da votação também são entregues pelo serviço postal.

Desde 2011, os Correios passaram a executar em parceria com o Fundo Nacional de Desenvolvimento da Educação (FNDE) a maior operação de distribuição de livros didáticos do mundo. Integrando a Programa Nacional do Livro Didático (PNLD), a empresa distribui anualmente cerca de 137 milhões de livros e dicionários às mais de 140 mil escolas públicas brasileiras, totalizando 74 mil toneladas de material ${ }^{200}$. Estudada por Rodrigues, Nagano e Musetti (2007), essa operação logística é bastante peculiar, pois deve realizar a entrega do material didático às unidades de ensino a tempo do início do ano letivo e em quantidade adequada conforme as matrículas realizadas para aquele período. Essa ação permite, na prática, que haja a unificação do sistema de ensino nacional sob uma base curricular comum e a superação da escassez de produção de material didático, especialmente para os lugares mais remotos.

\footnotetext{
${ }^{199}$ Os Correios se diferenciam dos portos secos e os Centros Logísticos e Industriais Aduaneiros, estudados por Penha (2010), pois estes são utilizados principalmente, como o autor indica, pelas grandes empresas.

${ }^{200}$ Segundo informações disponibilizadas em Correios (2016).
} 
Também em parceria com o Ministério da Educação (MEC), os Correios são o elo material que permite a realização dos exames nacionais de educação. Como aplicar provas como o Exame Nacional do Ensino Médio (ENEM), o Exame Nacional de Desempenho de Estudantes (ENADE), a Provinha Brasil, entre outros, em todos os municípios brasileiros simultaneamente? Durante o ENEM, as agências postais se transformam em locais oficias de inscrições, que somente em 2013 totalizou 7 milhões. A logística dos Correios realiza a entrega sigilosa das provas em todos os locais de aplicação cerca de uma hora antes do início do certame, e realiza a coleta após o encerramento das atividades, no mesmo dia. Em 2013 foram 47 mil malotes de ida e volta entregues em mais de 11 mil destinos no país. Desta maneira, o MEC garante o sigilo das provas e utiliza a rede postal como uma maneira eficiente e barata de realizar o exame em escala nacional. O mesmo ocorre no caso de concursos públicos: as parcerias entre os Correios e as instituições aplicadoras de exames é o que permite a concretização das ações coordenadas, com serviço completo de logística antes, durante e após a aplicação das provas.

No âmbito das políticas nacionais de saúde, os Correios participam da distribuição de vários materiais, desde cartazes das campanhas do Ministério da Saúde aos postos e hospitais até pequenos equipamentos, materiais cirúrgicos, etc. Na complexa etapa da distribuição do circuito espacial produtivo da vacina estudado por Bertollo (2013), acrescentamos que muitas vacinas só conseguem chegar às pequenas cidades, vilas e povoados por meio de um transporte especial providenciado pelos Correios.

Em casos de catástrofes "naturais" no país, como enchentes, secas, deslizamento de terra em bairros de encosta, incêndios, tornados, entre outros, os Correios são acionados para operações sazonais de distribuição de donativos. Nessas circunstâncias, as agências passam a funcionar temporariamente como postos de arrecadação de alimentos, roupas, medicamentos, brinquedos, etc. de onde são encaminhados para o local atingido para serem entregues pela agência postal local.

Esses são os casos mais destacados em escala nacional. Regional e localmente, outras instâncias estatais também realizam ações de políticas públicas que dependem estritamente dos serviços postais e sua rede de fixos geográficos. Em parceria com os Correios, a Prefeitura Municipal de São Paulo entrega mensalmente 1.700 toneladas de leite em cerca de 350 mil domicílios cadastrados, operação que mobiliza com exclusividade 190 empregados em 156 veículos dos Correios, perfazendo 3.120 diferentes rotas de distribuição na cidade.

A universalidade do serviço de correio, a distribuição dos fixos postais, os fluxos regionais de correspondências, as funções desempenhadas pelos Correios (não somente 
postal, mas de serviços financeiros, comerciais e de logística de Estado), sua relevância histórica para o país, sua importância econômica, política e social convidam para uma imperiosa defesa de seu caráter público, em favor da continuidade de suas ações em benefício de pessoas e lugares localizados nas periferias do Brasil. 
Elaborar uma reflexão e uma interpretação do correio brasileiro considerando sua complexidade e as múltiplas funções que desempenha na atualidade reclama o tratamento do tema da cidadania. Para Milton Santos, a realização concreta da cidadania somente se torna possível com a componente territorial. Para tanto, propõe um modelo cívico do território em substituição ao modelo econômico vigente, que se funda a partir de dois elementos - a cultura e o território. Para o autor, faz-se necessário

de um lado, uma instrumentação do território capaz de atribuir a todos os habitantes aqueles bens e serviços indispensáveis, não importa onde esteja a pessoa; e, de outro lado, uma adequada gestão do território, pela qual a distribuição geral dos bens e serviços públicos seja assegurada (SANTOS, [1987] 2007, p.18)

Nesse modelo, o território seria pensado visando uma política redistributiva, de maneira a permitir o acesso aos serviços fundamentais independentemente do lugar onde se esteja. Essas ações seriam fundamentais para garantir uma cidadania completa, com a satisfação das necessidades mais básicas e essenciais no lugar onde a população habita. Para isso, é necessário uma mudança no uso e na gestão do território que oriente para lógicas que extrapolem a busca pelo lucro. Essa proposta sob um novo paradigma de organização e planejamento do território deve ser entendida como um direito inalienável do cidadão, já que deixar ao mercado a prestação de serviços básicos à vida contribui para o acirramento das desigualdades e a seletividade de acesso.

Em sua proposta, Santos ([1987] 2007) elabora uma distinção entre os "fixos públicos" e os "fixos privados". Os fixos privados seriam aquelas infraestruturas construídas e controladas pelo mercado, cuja distribuição no território obedece à lógica da máxima lucratividade. Já no caso dos fixos públicos, sob o controle do Estado, a lógica de sua implantação difere do mercado e acompanha - ou deveria acompanhar - o suprimento das necessidades da população. Nesse sentido, os fixos públicos podem também ser considerados como "fixos sociais". A instalação de novos fixos sociais nos lugares contribuiria, assim, para alterar as condições de vida da população.

Compreendendo o serviço postal brasileiro como um serviço público, haveria correspondência entre a topologia dos Correios e o modelo cívico do território? Ao propor uma política orientada para a criação de fixos sociais, Santos ([1987] 2007, p.59) assegura que "no caso das cidades, bastaria um projeto consequente para dotar a população de 'fixos' sociais. E no interior, a necessidade é de criar, 'artificialmente', núcleos destinados a servir às populações em derredor, ou fortalecer aglomerações já existentes...”. Ao instalar agências em todas as cidades brasileiras e, além disso, ainda criar unidades de atendimento em vilas e áreas 
rurais mesmo quando os lucros da unidade não cobrem as despesas de seu funcionamento, ao garantir a entrega domiciliar em todos os escalões da rede urbana - da metrópole às cidades ribeirinhas da Amazônia - assegurando um serviço postal universal, os Correios se aproximam da noção de um modelo cívico, cujos fixos postais cumprem, em muitos casos, funções de fixos sociais.

Esse conjunto da materialidade e das ações dos Correios aponta para um modelo cívico do território, pautado na mais igualitária distribuição e na maior acessibilidade possível aos serviços públicos de qualidade, indispensáveis à consolidação da cidadania. Destarte, torna-se indispensável um planejamento territorial assumido pelo Estado, que crie condições materiais e normativas para impulsionar uma logística a favor dos lugares, com vistas a suprir as necessidades cotidianas de populações inteiras marginalizadas pelo mercado.

A logística deve ser problematizada enquanto uma atividade que, deixada exclusivamente ao mercado, mais se beneficia dos lugares e de suas virtualidades do que os favorece. Calcada no lucro, a logística empresarial é um modelo eficiente de drenagem dos recursos disponíveis nos lugares para os centros de gravidade da economia capitalista. $\mathrm{O}$ atual modelo que se impõe é aquele dos lugares para esse tipo de logística, onde as diferentes porções do território adequam suas infraestruturas, seu conteúdo técnico e normativo, e se rearranjam para permitir que a logística, espécie de Hermes contemporâneo, o deus da velocidade, possa reinar, especialmente para alguns. Urge pensar num outro modelo possível, aquele de uma logística para todos os lugares, onde estes tenham as suas necessidades básicas supridas e favorecidas pelos progressos técnicos da humanidade.

Embora associada aos interesses de mercado na atual fase da globalização, a logística nasceu no seio do Estado e deve ser problematizada como uma ação estratégica para a execução de políticas públicas. A logística postal, por seus atributos espaciais (espaço banal) e temporais (cotidiano), além da própria natureza do objeto postal e a diversidade dos agentes envolvidos, não pode ser assumida pelo mercado, dada a própria limitação do escopo de ação dos agentes privados. Ela se revela estreitamente a fim a um modelo mais igualitário de distribuição de bens e serviços básicos à população, se se compreende o correio como parte da infraestrutura do território e não apenas como um serviço complementar - o correio, mais que um operador logístico postal, é um elemento imanente do território.

Por sua importância histórica na formação socioespacial brasileira, o correio é um importante elo de integração territorial, não somente nas extintas administrações postais, mas sobretudo hoje. Essa atribuição geoestratégica do Estado encontra na instituição postal uma característica peculiar que possibilita articular todos os domicílios sob uma mesma lógica. 
Como relegar ao mercado tamanha atribuição? Certamente não é possível avançar em direção a um modelo cívico ao reduzir a integração do território à imagem da topologia seletiva das corporações postais privadas. $\mathrm{O}$ correio brasileiro, com toda a sua complexidade, nos deixa pistas para entender a construção desse projeto de futuro.

Este trabalho contribui para o debate em torno do monopólio postal brasileiro, ao demonstrar que esse quadro normativo assegura a sobrevivência da empresa nacional num cenário mundialmente competitivo e desigual, onde as corporações privadas se recusam a atuar nas regiões mais deficitárias, na perspectiva do mercado. A manutenção do monopólio estatal do setor postal significa, na prática, impedir que os lucros mais significativos sejam drenados para a iniciativa privada, cuja concentração em poucas empresas multinacionais levaria à inviabilidade da execução de políticas públicas que beneficiam a população brasileira. Nesse sentido, o fim do monopólio não é uma questão de interpretação, como querem os juristas, mas uma questão política e político-territorial. A própria atuação dos Correios em regiões e lugares não lucrativos já contempla o papel dessas agências, verdadeiros fixos sociais, como indutoras de políticas públicas e da cidadania, além da própria participação da empresa pública na criação de endereços. A logística dos Correios não pode ser diretamente comparada à das empresas postais privadas, pois o privilégio da empresa pública se torna, em realidade, a garantia da prestação dos serviços nas periferias do território. Mais que uma organização postal, os Correios são um agente estatal que possibilita a execução coordenada de políticas públicas. Portanto, as condições para essa atuação capilar em escala nacional devem ser asseguradas à luz de uma reserva de mercado que permita minimamente o equacionamento do custeio total da operação.

O serviço postal universal, como um direito, não pode estar dissociado do debate em torno do monopólio estatal, pois universalidade e livre-concorrência são princípios contraditórios. Levar os serviços a todos os lugares passou a ser interpretado como uma atribuição do Estado, num cenário onde as empresas privadas não são obrigadas a cumprir nenhuma ação para com esse princípio. Ora, se a atribuição de manter um serviço universal, com todo o custo que esse projeto acarreta, continua sob os auspícios do Estado, por que deixar ao mercado os nichos mais lucrativos do correio, sobretudo os serviços expressos oferecidos entre as metrópoles? No Brasil, os Correios são um bom exemplo de empresa pública eficiente que supre as exigências de serviços mais rápidos e modernos sem abdicar de ações de integração e universalização.

Desse modo, ratifica-se a importância de manter um serviço postal público no Brasil, especialmente pelas características que possui. Os fluxos majoritariamente regionais de 
correspondências desmistificam a ideia de um fluxo global e recoloca a questão nacional na ordem do dia: quem pode assumir os serviços na Amazônia ou no interior da região Nordeste, senão o Estado? A constatação de que mesmo no interior do país os fluxos postais interregionais (longa distância) são minoritários se comparados às trocas dentro de uma mesma região também relativiza a noção de um correio a serviço das empresas do circuito superior, cuja concentração na metrópole paulista dá uma dimensão da divisão territorial do trabalho, mas está longe de traduzir a complexidade do correio como um fenômeno multiescalar. Nesse sentido, a diversidade de agentes que utilizam o serviço postal desloca o debate do âmbito corporativo, que se alimenta dos interesses dos grandes postadores (e-commerce, mídia impressa, bancos e operadoras de títulos de pagamento, etc.) em fazer do correio a imagem de seus interesses, para alcançar na esfera pública o lugar de sua realização, permitindo a satisfação de todos os agentes independentemente de sua localização no território.

Os resultados apresentados convidam a um debate atual sobre o correio brasileiro considerando sua dimensão territorial, na encruzilhada entre os interesses externos e as necessidades internas do país. Amparadas em anseios geopolíticos e geoeconômicos, as empresas multinacionais de correio reproduzem a perversa ordem mundial vigente, que favorece exclusivamente os capitais concentrados nos países centrais e que busca, agora, o controle sobre os fluxos das cartas e encomendas de todo o mundo.

Neste momento quando a noção de "território postal único" parece ter se tornado uma panaceia, as desigualdades socioespaciais não permitem falar em homogeneização. Há antes uma psicosfera criada sob a ideia de fluxos e agentes globais, de um lado, e redução da importância das fronteiras e dos territórios nacionais, de outro, que vem em auxílio do projeto violento das empresas multinacionais. Desde a divisão internacional do trabalho até as desigualdades regionais de consumo e as diferenças na disposição da materialidade do meio geográfico (principalmente a infraestrutura de transporte) é possível identificar no correio diferentes usos do território, que se traduzem em redes postais exclusivas, na diversidade dos prazos de entrega e na multiplicação dos serviços.

No âmbito da divisão territorial do trabalho, a elaboração de uma tipologia e topologia dos Correios atrelada à rede urbana possibilita empiricizar o correio e romper com uma noção de "expresso" como temporalidade instantânea e homogênea. O tempo expresso não pode alcançar o território igualmente porque é exigente de condições similares de fluidez, daí sua seletividade e predominância nos espaços metropolitanos. Assim, a construção de um modelo cívico excede a vorticidade (leia-se: vorti-cidade) dos serviços expressos para incluir as múltiplas temporalidades dos lugares, de todos eles. Por isso deve-se insistir no fato de que as 
empresas postais privadas, ao priorizarem os serviços expressos, estão aquém de um modelo de consolidação da cidadania.

Deve-se compreender a velocidade em sua dimensão política, juntamente com a técnica. Para que e para quem a rapidez ou a lentidão? Onde elas têm lugar? Na construção de um modelo cívico, importará mais o tempo das necessidades da população e dos lugares do que o tempo mais expresso, produtor de alienação. Como demonstrado, não é possível entender a rapidez da circulação sem a sua contrapartida, a lentidão, do mesmo modo que os fluxos materiais e imateriais não são excludentes. As modernizações se instalam seletivamente no território, fazendo com que os elementos novos convivam com aqueles que se tornaram velhos e a integração daí decorrente não seja sinônimo de fim das diferenciações.

Buscou-se contribuir para a compreensão do papel da informação no território, entendendo os fluxos informacionais como parte da circulação do correio e sem os quais não se pode falar em serviços postais atualmente, principalmente os expressos. Como apresentado, os fluxos materiais e imateriais devem ser analisados conjuntamente, o que explica que a difusão da Internet foi equivalente ao aumento e aceleração do fluxo postal e não à sua superação; e quanto mais os fluxos imateriais se tornam espessos mais os fluxos materiais se densificam, e vice-versa.

$\mathrm{Na}$ atualidade, quando do mail (correio) chega-se ao e-mail (correio eletrônico), o princípio de inviolabilidade da correspondência contrasta com a invasão de privacidade das empresas de comunicação virtual. O sigilo das mensagens eletrônicas é diariamente quebrado por empresas como Google, Facebook, Whatsapp e inúmeras outras, seja pelo acesso não autorizado ao seu conteúdo ou pela permissão dos usuários exigida pelas empresas nos contratos de utilização do serviço. Além dos indivíduos, os Estados também passaram a ser espionados por grandes empresas e por outros Estados em suas trocas de correspondências por meios virtuais. Nessa conjuntura, manter o correio público significa assegurar ao menos uma via “inviolável".

A hierarquia não desaparece atualmente, mas adquire novos conteúdos e maior complexidade. Nem todos os lugares conseguem romper a amarra da trama escalar hierárquica, principalmente os espaços da lentidão dotados de sistemas técnicos menos modernos. Podemos considerar o território como agido, sofrendo a ação do Estado, do mercado e de diversos agentes que alteram o seu conteúdo e funcionamento por meio da norma e de diversas ações. Mas a materialidade, o conjunto das formas, continua nos autorizando a falar em um território ativo, pelo seu potencial de se impor às ações que se 
realizam. É a trama da diferenciação do território, que faz com que cada lugar seja singular e nem o tempo, nem mesmo o espaço, possam ser homogeneizados como um todo.

Com os resultados apresentados, novas perguntas e desafios de pesquisa podem ser formulados. Pelos objetivos estabelecidos, não foi possível analisar a logística postal na escala intraurbana e intrametropolitana, com a complexidade que envolve os serviços de entrega dentro das cidades, as rotas estabelecidas e o trabalho dos carteiros. Também foi apenas tangenciado o tema do e-commerce, esse novo produto do urbano exigente de fluidez e intensivo em informação.

O frenesi da velocidade é uma palavra de ordem do nosso período. Enquanto os serviços mais expressos são seletivos no território, um correio mais lento continua servindo a milhões de brasileiros todos os dias, seja para o envio de cartas, encomendas, recebimento de faturas de pagamento ou mesmo a compra pela Internet. Ubíquo e universal, esse correio, não do tempo do capital hegemônico que não pode parar, mas do tempo das pessoas que no seu cotidiano param para sorrir ao abrir uma correspondência, resiste e desafia a própria seletividade excludente do expresso no período atual. 


\section{REFERÊNCIAS}

AGUILAR PÉREZ, Antonio. Movimientos corporativos en los cuerpos de correos y telégrafos. De las comisiones a los sindicatos. Scripta Nova. Revista Electrónica de Geografía y Ciencias Sociales. Barcelona: Universidad de Barcelona, v. VI, n. 119 (103), 2002.

Correo electrónico versus correo tradicional, dos redes conectadas. Scripta Nova. Revista Electrónica de Geografía y Ciencias Sociales. Barcelona: Universidad de Barcelona, v. VIII, n. 170, 2004.

Liberalización y conexión de redes en las comunicaciones postales de Europa. Scripta Nova. Revista Electrónica de Geografía y Ciencias Sociales. Barcelona: Universidad de Barcelona, v. XII, n. 270 (33), 2008.

ALBON, Robert. The future of postal services. London: Institute of Economic Affairs, 1991.

ANGLADE, Henri. Trafic postal et cycle économique. Contribuition à l'étude de la sensibilité du secteur public aux crises. Paris: Presses Universitaires de Paris, 1946.

ANTAS JR., Ricardo Mendes. Território e regulação: espaço geográfico, fonte material e imaterial do direito. São Paulo: Associação Editorial Humanitas; FAPESP, 2005.

ARROYO, Mónica. A regulação do território no contexto da globalização (uma trama entre as formas globais, nacionais e locais). In: SOUZA, Álvaro et al. (org.). Paisagem, território, região. Em busca da identidade. Cascavel: Edunioeste, 2000, p.115-124.

Território, mercado e estado: uma convergência histórica. Geographia (UFF), Niterói, v.12, p.49-66, 2004.

A globalização pensada a partir do espaço geográfico. In: MENDONÇA, Francisco; SAHR, Cicilian; SILVA, Márcia. Espaço e tempo: complexidade e desafios do pensar e do fazer geográfico. Curitiba: Ademadan, 2009, p.479-496.

; CRUZ, Rita (orgs.). Território e circulação: a dinâmica contraditória da globalização. São Paulo: Annablume, 2015.

BADIE, Bertrand. La fin des territoires: essai sur le désordie international et sur l'utilité sociale du respect. Paris: Fayard, 1995.

BARAT, Joseph. Infraestruturas de logística e transporte: análise e perspectivas. In: SILVEIRA, Márcio Rogério (org.). Circulação, transportes e logística: diferentes perspectivas. São Paulo: Outras Expressões, 2011, p.217-246.

BARROS NETO, João. Administração pública no Brasil: uma breve história dos correios. São Paulo: Annablume, 2004.

BAUDRILLARD, Jean. O Sistema dos objetos. São Paulo: Perspectiva, 1973. 
BECKER, Bertha. Logística e nova configuração do território brasileiro: que geopolítica será possível? In: DINIZ, C. C. (org.). Políticas de desenvolvimento regional: desafios e perspectivas à luz das experiências da União Europeia e do Brasil. Brasília: Editora da Universidade de Brasília, 2007.

BERNARDES SILVA, Adriana. A contemporaneidade de São Paulo: produção de informações e novo uso do território brasileiro. 2001. 301 f. Tese (Doutorado em Geografia Humana) - Faculdade de Filosofia, Letras e Ciências Humanas, Universidade de São Paulo, São Paulo, 2001.

. O processo de mundialização da metrópole de São Paulo: tendências e conflitos. In: SOUZA, Maria Adélia A. (org.). Território brasileiro: usos e abusos. Campinas: Edições Territorial, 2003, p.194-212.

BERTOLLO, Mait. O circuito espacial produtivo da vacina do território brasileiro e a pandemia Influenza A H1N1. 2013. 269 f. Dissertação (Mestrado em Geografia Humana) - Faculdade de Filosofia, Letras e Ciências Humanas, Universidade de São Paulo, São Paulo, 2013.

BRAGA, Vanderlei; CASTILLO, Ricardo. Tipologia e topologia de nós logísticos no território brasileiro: uma análise dos terminais ferroviários e das plataformas multimodais. Boletim Campineiro de Geografia, v.3, n.2, p.235-258, 2013.

BRASIL. Lei $\mathbf{n}^{\mathbf{0}}$ 6.538, de 22 de junho de 1978. Dispõe sobre os serviços postais. Disponível em http://www.planalto.gov.br/ccivil_03/leis/L6538.htm. Acesso em 26 de agosto de 2016.

BRASIL. Constituição (1988). Constituição da República Federativa do Brasil. Brasília, DF: Senado, 1988.

BRAUDEL, Fernand. (1966) O mediterrâneo e o mundo mediterrâneo na época de Felipe II (2 vols.). São Paulo: Martins Fontes, 1983.

BRENNER, Neil. Between fixity and motion: accumulation, territorial organization and the historical geography of spatial scales. Environment and Planning D: society and space, vol. 16 (4), p.459-481, 1998.

BRUNET, Roger. L'enjeu du transport. In: Espace géographique. Tome 22, n.3, p. 219-232, 1993.

BOVO, Cassiano Ricardo. Os Correios no Brasil e a organização racional do trabalho. São Paulo: Annablume, 1997.

BOWEN JR., J. A spatial analysis of FedEx and UPS: hubs, spokes, and network structure. Journal of Transport Geography, vol. 24, p. 419-431, 2012.

CAIRNCROSS, Frances. The death of distance: how the communications revolution will change our lives. Boston: Harvard Business School Press, 2001.

CAMILO PEREIRA, Ana Paula. Asas da centralidade em céus conhecidos: a dinâmica do setor de transporte aéreo no território brasileiro. 2014. 375 f. Tese (Doutorado em Geografia 
Humana) - Faculdade de Filosofia, Letras e Ciências Humanas, Universidade de São Paulo, São Paulo, 2014.

CAPRA, Fritjof. A teia da vida: uma nova compreensão científica dos sistemas vivos. 3. ed. São Paulo: Cultrix, 1998.

CARNEIRO, Maria Neuenschwander Escosteguy. Uma nova visão do setor postal brasileiro. Rio de Janeiro: Editora Lumen Juris, 2006.

CASTELLS, Manuel. A sociedade em rede. A era da informação: economia, sociedade e cultura (vol. 1). São Paulo: Paz e Terra, 1999.

CASTILLO, Ricardo. Agricultura globalizada e logística nos cerrados brasileiros. In: SILVEIRA, Márcio Rogério (org.). Circulação, transporte e logística: diferentes perspectivas. São Paulo: Outras Expressões, 2011, p.331-354.

CHESNAIS, François. A mundialização do capital. São Paulo: Xamã, 1996.

CIDELL, Julie. Concentration and decentralization: the new geography of freight distribution in US metropolitan areas. Journal of Transport Geography, v.18, p. 363-371, 2008.

CONTEL, Fábio Betioli. Território e finanças: técnicas, normas e topologias bancárias no Brasil. 2006. 343 f. Tese (Doutorado em Geografia Humana) - Faculdade de Filosofia, Letras e Ciências Humanas, Universidade de São Paulo, São Paulo, 2006.

CORRÊA, Roberto Lobato. Interações Espaciais. In: CASTRO, I. E. de; GOMES, P. C. da C.; CORRÊA, R. L. (Org.). Explorações Geográficas. 2 ed. Rio de Janeiro: Bertrand Brasil, [1997] 2006, p.279-318.

Redes Geográficas - cinco pontos para discussão. In: VASCONCELOS, Pedro de Almeida; SILVA, Sylvio Bandeira de Mello e (orgs.). Novos estudos de geografia urbana brasileira. Salvador: Editora da Universidade Federal da Bahia, 1999, p.65-70.

Estudos sobre a rede urbana. Rio de Janeiro: Bertrand Brasil, 2006.

CORREIOS. História postal. Disponível em < http://www.correios.com.br/sobre-correios/aempresa/historia >. Acesso em: 21 ago. 2016.

COWEN, Deborah. The deadly life of logistics: mapping violence in global trade. Minneapolis; London: University of Minnesota Press, 2014.

CRUZ, Daniella. Estratégia de produção no setor de serviços: um estudo de caso na Empresa Brasileira de Correios e Telégrafos. 2007. 124 f. Dissertação (Mestrado em Engenharia da Produção). Centro de Ciências Exatas e Tecnologia, Universidade Federal de São Carlos, São Carlos, 2007.

DANTAS, Marcos. A lógica do capital informação: a fragmentação dos monopólios e a monopolização dos fragmentos num mundo de comunicações globais. Rio de Janeiro: Contraponto, 1996. 
DIAS, Leila. Réseaux d'information et réseaux urbain au Brésil. Paris: L'Harmattan, 1995.

(1996) Redes eletrônicas e novas dinâmicas do território brasileiro. In: CASTRO, Iná Elias; GOMES, Paulo César da Costa; CORRÊA, Roberto Lobato (orgs.). Brasil: questões atuais da reorganização do território. 6 ed. Rio de Janeiro: Bertrand Brasil, 2010, p.115-144.

Os sentidos da rede: notas para discussão. In: ; SILVEIRA, Rogério L. L. (org.). Redes, sociedades e territórios. Santa Cruz do Sul: Edunisc, 2005. p.11-28.

. Finanças, política e território. Caderno CRH (UFBA), v.22, n.55, p.9-13, 2009.

DICKEN, Peter. (1986) Global shift: mapping the changing contours of the world economy. 6 ed. New York/London: The Guilford Press, 2011.

DUPUY, Gabriel. Géographie et économie des réseaux. In: Espace géographique. Tome 22, n.3, p. 193-209, 1993.

ECKERT, Sandra. Between commitment and control: varieties of delegation in the European postal sector. In: Journal of European Public Policy, 17:8, p.1231-1252, 2010.

FERREIRA, Aurélio B. de Hollanda. Novo dicionário Aurélio da língua portuguesa. Curitiba: Positivo, 2009.

FUKUYAMA, Francis. The end of history and the last man. New York: Free Press, 2006.

FURTADO, Celso. (1959) Formação econômica do Brasil. 34 ed. São Paulo: Companhia das Letras, 2007.

GALLO, Fabrício. O papel do transporte aéreo na integração do território brasileiro. 2006. 121 f. Dissertação (Mestrado em Geografia) - Instituto de Geociências, Universidade Estadual de Campinas, Campinas-SP, 2006.

GEORGE, Pierre. Geografia econômica. 5 ed. Rio de Janeiro: Editora Fundo de Cultura, 1970.

GERTEL, Sérgio. Geografia, informação e comunicação: a imagem postal brasileira. 1991. 274 f. Dissertação (Mestrado em Geografia Humana). Departamento de Geografia, Faculdade de Filosofia, Letras e Ciências Humanas, Universidade de São Paulo, São Paulo, 1991.

GOTTMANN, Jean. La politique des États et leur géographie. Paris: Librairie Armand Colin, 1952.

. (1975) A evolução do conceito de território. In: Boletim Campineiro de Geografia, v.2, n.3, p.523-545, 2012.

GROOVER, Mikell. Automation, production systems and computer-integrated manufacturing. New Jersey: Prentice Hall, 2001. 
HAESBAERT, Rogério. O mito da desterritorialização: do "fim dos territórios" à multiterritorialidade. 6 ed. Rio de Janeiro: Bertrand Brasil, 2011.

HÄGERSTRAND, Torsten. (1952) A propagação de ondas de inovação. Tradução de Melissa Steda e Wagner Nabarro. Boletim Campineiro de Geografia, v.3, n.2, p.348-368, 2013.

HARVEY, David. (1989) Condição pós-moderna: uma pesquisa sobre as origens da mudança cultural. 21 $1^{\text {a }}$ ed. São Paulo: Loyola, 2011.

. (2005) O neoliberalismo: história e implicações. 5ª ed. São Paulo: Loyola, 2014.

HENKIN, David. The postal age: the emergence of modern communications in nineteenthcentury America. Chicago: The University of Chicago Press, 2006.

HOBSBAWM, Eric. Era dos Extremos: o breve século XX (1914-1991). Trad. Marcos Santarrita. Rev. téc. Maria Célia Paoli. 2 ed. São Paulo: Companhia das Letras, 1995.

HUERTAS, Daniel. Território e circulação: transporte rodoviário de carga no Brasil. 2013. 443 f. Tese (Doutorado em Geografia Humana) — Faculdade de Filosofia, Letras e Ciências Humanas, Universidade de São Paulo, São Paulo, 2013.

IANNI, Octávio. (1995) Teorias da globalização. 16 ${ }^{\mathrm{a}}$ ed. Rio de Janeiro: Civilização Brasileira, 2010a.

(1996) A era do globalismo. 10ª ed. Rio de Janeiro: Civilização Brasileira, 2010b.

IBGE. Regiões de Influência das Cidades - 2007. Rio de Janeiro: Instituto Brasileiro de Geografia e Estatística, 2008.

JI, Ping; CHEN, Keija. The vehicle routing problem: the case of the Hong Kong Postal Service. In: Transportation Planning and Technology, 30:2-3, p.167-182, 2007.

KAHIL, Samira. Usos do território: uma questão política. Estudos Geográficos, Rio Claro, v. 10, n.2, p.26-36, jul./dez. 2012.

LENCIONI, Sandra. Metamorfose metropolitana: dispersão especial e fragmentação do urbano em Buenos Aires e São Paulo. In: ARROYO, Mónica; ZUSMAN, Perla (orgs). Argentina e Brasil: possibilidades e obstáculos no processo de integração territorial. São Paulo: Humanitas; Buenos Aires: Facultad de Filosofia y Letras, 2010.

LÉVY, Jacques. A-t-on encore (vraiment) besoin du territoire? Espaces Temps, 51, p. 102$142,1993$.

LOPES, Humberto; MOURA, Thelmo; OLIVEIRA, Caio. Os perfis estratégicos no Brasil: um estudo dos agentes franqueados dos correios a partir da tipologia de Miles e Snow. In: Revista Brasileira de Gestão de Negócios, v.12, n.37, p.388-404, 2010.

MARGUERIT, Mathilde. La mise en place du réseau postal dans les campagnes du XIXe siècle. Un étude de cas: le department du Nord. In: Flux, n. 42, p.48-59, 2000. 
MASUTTI, Anna. La liberalizzazione dei transporti in Europa. Milano: Dott. A. Giuffrè Editore, 2002.

MATTELART, Armand. Comunicação-mundo: história das ideias e das estratégias. Trad. Guilherme J. F. Teixeira. 2 ed. Petrópolis: Vozes, 1994.

MARTINS, Mariângela Kretzer. Responsabilidade social na Empresa Brasileira de Correios e Telégrafos - Diretoria Regional de Santa Catarina: um estudo do clima organizacional e do balanço social na percepção dos stakeholders internos. 2007. 215 f. Dissertação (Mestrado em Administração) - Universidade do Vale do Itajaí, Biguaçu-SC, 2007.

MARX, Karl. (1859) Contribuição à crítica da economia política. $2^{a}$ ed. São Paulo: Expressão Popular, 2008.

MEDEIROS, Dhiego. Financeirização do território e circuitos da economia urbana: agentes de crédito, técnicas e normas bancárias. Um exemplo em Alagoas. 2013. $275 \mathrm{f}$. Dissertação (Mestrado em Geografia Humana) - Faculdade de Filosofia, Letras e Ciências Humanas, Universidade de São Paulo, São Paulo, 2013.

MESQUITA, Clarissa. O regime jurídico do setor postal: desafios contemporâneos e perspectivas para o setor. 2012. 193 f. Dissertação (Mestrado em Direito) - Faculdade de Direito da Universidade de São Paulo, São Paulo, 2012.

MONTGOMERY, Neil. A União Postal Universal: um modelo de organização internacional. 2002. 384 f. Dissertação (Mestrado em Direito) - Faculdade de Direito da Universidade de São Paulo, São Paulo, 2002.

MONIÉ, Frédéric. Dinâmicas produtivas, logística e desenvolvimento territorial. In: VIDEIRA, Sandra; COSTA, Perre; FAJARDO, Sérgio (orgs.). Geografia econômica: (re)leituras contemporâneas. Rio de Janeiro: Letra Capital, 2011, p.145-167.

MORAES, Antonio Carlos Robert. Território e história no Brasil. 2 ed. São Paulo: Annablume, 2005.

MOREIRA, Ruy. Geografia e práxis: a presença do espaço na teoria e na prática geográficas. São Paulo: Contexto, 2012.

MUSSO, Pierre. A filosofia da rede. In: PARENTE, André (org.). Tramas da rede: novas dimensões filosóficas, estéticas e políticas da comunicação. Porto Alegre: Sulina, 2004, p.1738.

NOVAES, Antônio Galvão. Logística e gerenciamento da cadeia de distribuição: estratégia, operação e avaliação. 10 reimpr. Rio de Janeiro: Elsevier, 2007.

O'BRIEN, Richard. Global financial integration: the end of geography. New York: The Royal Institute of International Affairs and Council on foreign Relations Press, 1992.

OGER, Benoît. Les mutations de La Poste de 1792 à 1990, entre ruptures et continuités. Flux, n. 42, p.7-21, 2000. 
OHMAE, Kenichi. The borderless world: power and strategy in the interlinked economy. New York: Harper Business, 1999.

OLIVEIRA, Denise. O papel da universidade corporativa no setor público brasileiro: um estudo de caso nos Correios. 2007. 93 f. Dissertação (Mestrado em Administração), Faculdade de Economia, Administração, Contabilidade e Ciência da Informação e Documentação, Universidade de Brasília, Brasília, 2007.

PENHA, Lucas. Os Centros Logísticos e Industriais Aduaneiros e a atual indústria paulista. Dissertação (Mestrado em Geografia Humana) - Faculdade de Filosofia, Letras e Ciências Humanas, Universidade de São Paulo, São Paulo, 2010.

PEREIRA, Evelyn. A empresa e o lugar na globalização: a "responsabilidade social empresarial" no território brasileiro. 2007. 205 f. Dissertação (Mestrado em Geografia Humana) - Faculdade de Filosofia, Letras e Ciências Humanas, Universidade de São Paulo, São Paulo, 2007.

PORTEOUS, David. The development of financial centres: location, information, externalities and path dependence. In: MARTIN, Ron (org.). Money and space economy. Sussex: John Wiley and Sons, p. 95-114, 1999.

POUPARD, Iza. O papel do Brasil na regulação das relações internacionais postais: uma contribuição à história dos Correios. 1979. 136f. Dissertação (Mestrado em História) Instituto de Ciências Humanas, Universidade de Brasília, Brasília, 1979.

QUEIROZ, Kristian. Centralidade periférica e integração relativizada - uma leitura de Tefé no Amazonas. 2015. 325 f. Tese (Doutorado em Geografia Humana) - Faculdade de Filosofia, Letras e Ciências Humanas, Universidade de São Paulo, São Paulo, 2015.

RAFFESTIN, Claude. Por uma geografia do poder. São Paulo: Ática, 1993.

REGUERA, Antonio. La lucha postal por el territorio. Scripta Nova. Revista Electrónica de Geografía y Ciencias sociales. Barcelona: Universidad de Barcelona, vol. XI, nº 237, 2007.

ROBERTS, Susan. Global regulation and trans-state organization. In: JOHNSTON, R. J. et al (ed.). Geographies of global change: remapping the world in the late twentieth century. Oxford: Blackell Publishers, 1995, p.111-126.

ROCHEFORT, Michel. Redes e sistemas. Trad. Antonio de Pádua Danesi. São Paulo: Hucitec, 1998.

RODRIGUES, Edna; NAGANO, Marcelo; MUSETTI, Marcel. As especificidades da logística integrada dos Correios: um estudo de caso. Revista de ciências gerenciais, Valinhos, v.11, n.13, p.66-73, 2007.

ROSARIO, Irari. Três séculos e meio da história postal brasileira. Rio de Janeiro: Empresa Brasileira de Correios e Telégrafos, 1993. 
SAINT-EXUPÉRY, Antoine de. (1929) Correio Sul. 5 ed. São Paulo: Difusão Europeia do Livro, 1966.

SANTOS, Milton. (1978) Por uma geografia nova: da crítica da geografia a uma geografia crítica. $6^{\text {a }}$ ed. $1^{\text {a }}$ reimpr. São Paulo: Edusp, 2008a.

(1979) O espaço dividido: os dois circuitos da economia urbana nos países subdesenvolvidos. 2 ed. São Paulo: Edusp, 2004.

. (1987) O espaço do cidadão. 7 ed. São Paulo: Edusp, 2007.

. (1988) Metamorfoses do espaço habitado: fundamentos teóricos e metodológicos da Geografia. 6 ed. São Paulo, Edusp, 2012a.

(1993) A urbanização brasileira. 5 ed. São Paulo: Edusp, 2008b.

(1993) O retorno do território. In: ; SOUZA, Maria Adélia A.; SILVEIRA,

María Laura (orgs.). Território: globalização e fragmentação. 5 ed. São Paulo: Hucitec/ANPUR, 2006, p.15-20.

A aceleração contemporânea: tempo mundo e espaço mundo. In: et al (orgs.). O novo mapa do mundo: fim de século e globalização. 2 ed. São Paulo: Hucitec/ANPUR, 1994.

(1994) Técnica, espaço, tempo: globalização e meio técnico-científico informacional. 5. ed. SãoPaulo: Edusp, 2008c.

. (1996) A natureza do espaço. Técnica e tempo. Razão e emoção. 4 ed. 7 reimpr. São Paulo: Edusp, 2012b.

. (2000) Por uma outra globalização: do pensamento único à consciência universal. $20^{\mathrm{a}}$ ed. Rio de Janeiro: Record, 2011.

. (2005) Da totalidade ao lugar. $1^{\mathrm{a}}$ ed. $1^{\mathrm{a}}$ reimpr. São Paulo: Edusp, 2008c.

; SILVEIRA, María Laura. (2001) O Brasil: território e sociedade no início do século XXI. 15 ed. Rio de Janeiro: Record, 2011.

SAVY, Michel. Logistique et territoire. In: Espace géographique. Tome 22, n. 3, p. 210-218, 1993.

SCHERER-WARREN, Ilse. Cidadania sem fronteiras: ações coletivas na era da globalização. São Paulo: Hucitec, 1999.

SIDERO, Antonio. El negocio postal: la entrega del correo. Buenos Aires: [S.1.], 1997.

SILVA, Moacir. Geografia dos transportes no Brasil. Rio de Janeiro: IBGE, 1949. 
SILVA JR., Roberto França da. Circulação e logística territorial: a instância do espaço e a circulação corporativa. 2009. 374 f. Tese (Doutorado em Geografia) - Faculdade de Ciências e Tecnologia, Universidade Estadual Paulista, Presidente Prudente, 2009.

SILVEIRA, Márcio Rogério. As cinco revoluções e evoluções logísticas e seus impactos sobre o território brasileiro. In: SILVERA, Márcio Rogério; LAMOSO, Lisandra Pereira; MOURÃO, Paulo Fernando Cirino (orgs.). Questões nacionais e regionais do território brasileiro. São Paulo: Expressão Popular, 2009, p.13-42.

SILVEIRA, María Laura. Uma globalização desnecessária, um território instável. Ciência Geográfica, Bauru, v.1 (21), p.43-46, 2002.

Ao território usado a palavra: pensando princípios de solidariedade socioespacial. In: Viana, A. L. A.; Ibañez, N.; Elias, P. E. M. (orgs.). Saúde, Desenvolvimento e Território. 1 ed. São Paulo: Hucitec, 2009, p. 127-150.

SINGER, Paul. Divisão internacional do trabalho e empresas multinacionais. In: Caderno CEBRAP 28: Multinacionais: Internacionalização e crise. São Paulo: CEBRAP, 1976, p.48-86.

SOUZA, José Garcia de. A epopeia do correio aéreo. Rio de Janeiro: Empresa Gráfica Ouvidor, 1946.

SOUZA, Marcelo Lopes de. ABC do desenvolvimento urbano. 3 ed. Rio de Janeiro: Bertrand Brasil, 2007.

SPOSITO, Eliseu. Território, logística e mundialização do capital. In: (org.).

Dinâmica econômica, poder e novas territorialidades. Presidente Prudente: GAsPERR/UNESP, 1999, p. 99-113.

Redes e cidades. São Paulo: Editora UNESP, 2008.

SPOSITO, Maria Encarnação Beltrão. Capitalismo e urbanização. 15 ed. São Paulo: Contexto, 2005.

Novas redes urbanas: cidades médias e pequenas no processo de globalização.

Geografia (Rio Claro), v.35, n.1, p.51-62, 2010.

TEIXEIRA, Tadeu Gomes. Os Correios em transformação: reestruturação, organização do trabalho e políticas de gestão do trabalho (1994-2011). 2013. 303 f. Tese (Doutorado em Ciências Sociais). Instituto de Filosofia e Ciências Humanas, Universidade Estadual de Campinas, Campinas, 2013.

THRIFT, Nigel. Inhuman geographies: landscapes of speed, light and power. In: (ed.). Spatial formations. London: Sage, 1996.

TREVISAN, Leandro. Os operadores logísticos e o uso do território brasileiro: racionalidade e fluidez aos circuitos espaciais de produção. 2007. 134 f. Dissertação (Mestrado em Geografia) - Instituto de Geociências, Universidade Estadual de Campinas, Campinas, 2007. 
TZU, Sun. A arte da guerra: os treze capítulos. Trad. Pedro Manoel Soares. Barueri: Ciranda Cultural, 2015.

UPU. Doha postal strategy 2013-2016: the global roadmap for postal services. Berna: Universal Postal Union, 2012. Disponível para acesso online em http://www.upu.int/en/theupu/strategy/doha-postal-strategy.html.

Status and structures of postal entities in UPU member countries. Berna: Universal Postal Union, 2016. Disponível para acesso online em http://www.upu.int/en/theupu/status-of-postal-entities/about-status-of-postal-entities.html.

VELTZ, Pierre. Mondialisation, villes et territoires. L'économie d'archipel. Paris: Presses Universitaires de France, 1996.

VENCESLAU, Igor. Logística postal e uso do território no sul da Bahia. Boletim Campineiro de Geografia, v.2, n.3, p.500-521, 2012.

VIRILIO, Paul. Vitesse et politique. Paris: Editions Galilée, 1977.

- (1984) O espaço crítico: e as perspectivas do tempo real. Edição revisada e aumentada pelo autor; tradução de Paulo Roberto Pires. 2 ed. São Paulo: Editora 34, 2014.

WALSH, John. Labor struggle in the Post Office: from selective lobbying to collective bargaining. New York/London: M. E. Sharpe, 1992.

WOOD, Andrew; ROBERTS, Susan. Economic geography: places, networks and lows. New York: Routledge, 2011.

XAVIER, Emanuella Moreira Pires. Exploração do serviço postal: existe o monopólio da União? Porto Alegre: Sergio Antonio Fabris Ed., 2007. 


\section{ANEXO A. Regionalização do território brasileiro por faixas de CEP}

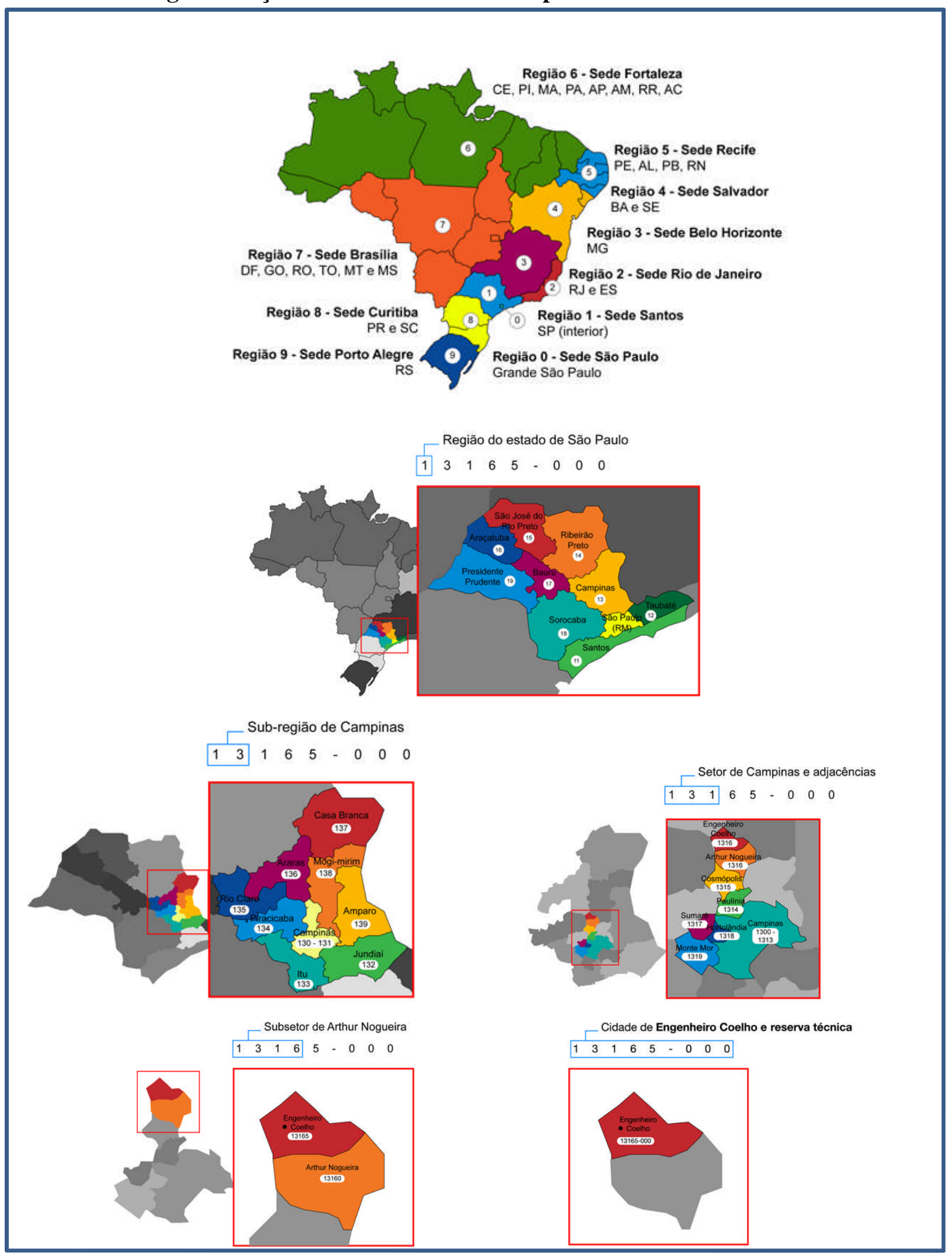

Fonte: Website dos Correios, no endereço https://www.correios.com.br/para-voce/precisa-de-ajuda/o-que-e-cepe-por-que-usa-lo/estrutura-do-cep. 
ANEXO B. Cidades com prazo de entrega dos Correios de 1 dia útil no Brasil

\begin{tabular}{|c|c|c|c|}
\hline UF & CIDADE & $\begin{array}{c}\text { CEP } \\
\text { INICIAL }\end{array}$ & $\begin{array}{c}\text { CEP } \\
\text { FINAL }\end{array}$ \\
\hline $\mathrm{AC}$ & Rio Branco & $69900-000$ & 69920-999 \\
\hline $\mathrm{AL}$ & Maceió & $57000-000$ & 57099-999 \\
\hline $\mathrm{AM}$ & Manaus & $69000-000$ & 69099-999 \\
\hline $\mathrm{AP}$ & Macapá & $68900-000$ & 68909-999 \\
\hline $\mathrm{BA}$ & Camaçari & $42800-000$ & 42819-999 \\
\hline $\mathrm{BA}$ & Feira de Santana & $44000-000$ & 44099-999 \\
\hline $\mathrm{BA}$ & Lauro de Freitas & $42700-000$ & 42799-999 \\
\hline $\mathrm{BA}$ & Salvador & 40000-000 & 42499-999 \\
\hline $\mathrm{BA}$ & Simões Filho & $43700-000$ & 43799-999 \\
\hline $\mathrm{CE}$ & Fortaleza & $60000-000$ & $61599-999$ \\
\hline $\mathrm{CE}$ & Caucaia & $61600-000$ & $61679-999$ \\
\hline $\mathrm{CE}$ & Maracanaú & $61900-000$ & 61939-999 \\
\hline $\mathrm{DF}$ & \multirow{2}{*}{ Brasília } & $70000-000$ & 70639-999 \\
\hline $\mathrm{DF}$ & & $70700-000$ & 70999-999 \\
\hline $\mathrm{DF}$ & Cruzeiro & 70640-000 & 70699-999 \\
\hline DF & Guará & $71000-000$ & 71399-999 \\
\hline DF & Lago Norte & $71500-000$ & 71569-999 \\
\hline DF & Paranoá & $71570-000$ & 71599-999 \\
\hline DF & Lago Sul & $71600-000$ & 71689-999 \\
\hline $\mathrm{DF}$ & \multirow{2}{*}{ Núcleo Bandeirante } & $71700-000$ & $71724-999$ \\
\hline DF & & 71730-000 & 71799-999 \\
\hline $\mathrm{DF}$ & Candangolândia & $71725-000$ & $71729-999$ \\
\hline $\mathrm{DF}$ & Riacho Fundo & $71800-000$ & 71899-999 \\
\hline $\mathrm{DF}$ & Taguatinga & 71900-000 & 72199-999 \\
\hline $\mathrm{DF}$ & Ceilândia & $72200-000$ & $72299-999$ \\
\hline DF & Samambaia & $72300-000$ & 72399-999 \\
\hline DF & Gama & $72400-000$ & 72499-999 \\
\hline DF & Santa Maria & $72500-000$ & 72599-999 \\
\hline DF & Recanto das Emas & $72600-000$ & 72699-999 \\
\hline DF & Sobradinho & $73000-000$ & 73299-999 \\
\hline ES & Cariacica & $29140-000$ & $29159-999$ \\
\hline $\mathrm{ES}$ & Serra & 29160-000 & 29182-999 \\
\hline $\mathrm{ES}$ & Vila Velha & 29100-000 & 29134-999 \\
\hline $\mathrm{ES}$ & Vitória & $29000-000$ & 29099-999 \\
\hline GO & Aparecida de Goiânia & $74900-000$ & 74994-999 \\
\hline GO & Goiânia & $74000-000$ & 74894-999 \\
\hline MA & São Luís & $65000-000$ & 65099-999 \\
\hline MG & Belo Horizonte & $30000-000$ & 31999-999 \\
\hline $\mathrm{MG}$ & Betim & $32500-000$ & 32799-999 \\
\hline $\mathrm{MG}$ & Contagem & $32000-000$ & $32399-999$ \\
\hline MG & Juiz de Fora & $36000-000$ & $36099-999$ \\
\hline $\mathrm{MG}$ & Nova Lima & $34000-000$ & $34299-999$ \\
\hline MG & Ribeirão das Neves & $33800-000$ & 33979-999 \\
\hline $\mathrm{MG}$ & Sabará & $34500-000$ & $34739-999$ \\
\hline MG & Santa Luzia & $33000-000$ & 33199-999 \\
\hline MG & Uberaba & $38000-000$ & 38099-999 \\
\hline MG & Uberlândia & $38400-000$ & 38415-999 \\
\hline MG & Varginha & $37000-000$ & 37109-999 \\
\hline MG & Vespasiano & $33200-000$ & 33349-999 \\
\hline
\end{tabular}

\begin{tabular}{|c|c|c|c|}
\hline MS & Campo Grande & 79000-000 & 79124-999 \\
\hline MT & Cuiabá & $78000-000$ & 78099-999 \\
\hline MT & Várzea Grande & $78110-000$ & 78169-999 \\
\hline PA & Ananindeua & $67000-000$ & 67199-999 \\
\hline $\mathrm{PA}$ & Belém & $66000-000$ & $66899-999$ \\
\hline $\mathrm{PB}$ & Campina Grande & $58100-000$ & \begin{tabular}{|l|}
$58109-999$ \\
\end{tabular} \\
\hline PB & João Pessoa & $58000-000$ & 58099-999 \\
\hline PB & Santa Rita & $58300-000$ & $58304-999$ \\
\hline $\mathrm{PE}$ & Abreu e Lima & $53500-000$ & $53599-999$ \\
\hline $\mathrm{PE}$ & Cabo de Santo Agostinho & $54500-000$ & 54569-999 \\
\hline $\mathrm{PE}$ & Camaragibe & $54750-000$ & 54799-999 \\
\hline $\mathrm{PE}$ & Jaboatão dos Guararapes & $54000-000$ & $54499-999$ \\
\hline PE & Olinda & $53000-000$ & 53399-999 \\
\hline $\mathrm{PE}$ & Paulista & $53400-000$ & 53499-999 \\
\hline $\mathrm{PE}$ & Recife & $50000-000$ & $52999-999$ \\
\hline PI & Teresina & $64000-000$ & 64099-999 \\
\hline PR & Araucária & $83700-000$ & $83724-999$ \\
\hline PR & Campo Largo & $83600-000$ & $83640-999$ \\
\hline $\mathrm{PR}$ & Colombo & $83400-000$ & $83415-999$ \\
\hline PR & Curitiba & $80000-000$ & $82999-999$ \\
\hline $\mathrm{PR}$ & Londrina & $86000-000$ & $86099-999$ \\
\hline PR & Maringá & $87000-000$ & 87099-999 \\
\hline PR & Paranaguá & $83200-000$ & 83249-999 \\
\hline PR & Pinhais & $83320-000$ & $83349-999$ \\
\hline PR & Ponta Grossa & $84000-000$ & 84099-999 \\
\hline PR & São José dos Pinhais & $83000-000$ & 83149-999 \\
\hline $\mathrm{RJ}$ & Duque de Caxias & $25000-000$ & $25499-999$ \\
\hline $\mathrm{RJ}$ & Niterói & $24000-000$ & 24399-999 \\
\hline RJ & \multirow{2}{*}{ Nova Iguaçu } & $26000-000$ & $26099-999$ \\
\hline $\mathrm{RJ}$ & & $26200-000$ & $26299-999$ \\
\hline $\mathrm{RJ}$ & Petrópolis & $25600-000$ & $25779-999$ \\
\hline RJ & Rio de Janeiro & $20000-000$ & $23799-999$ \\
\hline RJ & São Gonçalo & $24400-000$ & 24799-999 \\
\hline $\mathrm{RJ}$ & São João de Meriti & $25500-000$ & $25599-999$ \\
\hline $\mathrm{RN}$ & Natal & $59000-000$ & $59139-999$ \\
\hline $\mathrm{RN}$ & Parnamirim & 59140-000 & $59161-999$ \\
\hline $\mathrm{RO}$ & Porto Velho & 76800-000 & 76833-999 \\
\hline $\mathrm{RR}$ & Boa Vista & 69300-000 & $69339-999$ \\
\hline $\mathrm{RS}$ & Alvorada & $94800-000$ & 94889-999 \\
\hline $\mathrm{RS}$ & Cachoeirinha & $94900-000$ & 94999-999 \\
\hline $\mathrm{RS}$ & Campo Bom & $93700-000$ & 93799-999 \\
\hline RS & Canoas & $92000-000$ & 92479-999 \\
\hline $\mathrm{RS}$ & Esteio & $93250-000$ & 93299-999 \\
\hline $\mathrm{RS}$ & Gravataí & $94000-000$ & 94329-999 \\
\hline $\mathrm{RS}$ & Guaíba & $92500-000$ & 92849-999 \\
\hline $\mathrm{RS}$ & Novo Hamburgo & 93300-000 & 93599-999 \\
\hline $\mathrm{RS}$ & Porto Alegre & 90000-000 & 91999-999 \\
\hline $\mathrm{RS}$ & São Leopoldo & $93000-000$ & 93179-999 \\
\hline $\mathrm{RS}$ & Sapucaia do Sul & $93200-000$ & 93249-999 \\
\hline $\mathrm{RS}$ & Viamão & $94400-000$ & 94729-999 \\
\hline
\end{tabular}




\begin{tabular}{|l|c|c|c|}
\hline SC & Biguaçu & $88160-000$ & $88160-999$ \\
\hline SC & Blumenau & $89000-000$ & $89099-999$ \\
\hline SC & Florianópolis & $88000-000$ & $88099-999$ \\
\hline SC & Joinville & $89200-000$ & $89239-999$ \\
\hline SC & Palhoça & $88130-000$ & $88138-999$ \\
\hline SC & São José & $88100-000$ & $88123-999$ \\
\hline SE & Aracaju & $49000-000$ & $49098-999$ \\
\hline SE & Nossa Senhora do Socorro & $49160-000$ & $49169-999$ \\
\hline SP & Americana & $13465-000$ & $13479-999$ \\
\hline SP & Araçatuba & $16000-000$ & $16129-999$ \\
\hline SP & Araraquara & $14800-000$ & $14811-999$ \\
\hline SP & Atibaia & $12940-000$ & $12954-999$ \\
\hline SP & Bauru & $17000-000$ & $17109-999$ \\
\hline SP & Birigui & $16200-000$ & $16209-999$ \\
\hline SP & Campinas & $13000-000$ & $13139-999$ \\
\hline SP & Franca & $14400-000$ & $14414-999$ \\
\hline SP & Hortolândia & $13183-000$ & $13189-999$ \\
\hline SP & Indaiatuba & $13330-000$ & $13349-999$ \\
\hline SP & Itu & $13300-000$ & $13314-999$ \\
\hline SP & Jacareí & $12300-000$ & $12349-999$ \\
\hline SP & Jaguariúna & $13820-000$ & $13824-999$ \\
\hline SP & Jaú & $17200-000$ & $17219-999$ \\
\hline SP & Jundiaí & $13200-000$ & $13219-999$ \\
\hline SP & Limeira & $13480-000$ & $13489-999$ \\
\hline SP & Marília & $17500-000$ & $17529-999$ \\
\hline SP & Paulínia & $13140-000$ & $13149-999$ \\
\hline SP & Piracicaba & $13400-000$ & $13439-999$ \\
\hline SP & Presidente Prudente & $19000-000$ & $19109-999$ \\
\hline SP & Ribeirão Preto & $14000-000$ & $14110-999$ \\
\hline SP & Rio Claro & $13500-000$ & $13507-999$ \\
\hline SP & Santa Bárbara d'Oeste & $13450-000$ & $13459-999$ \\
\hline SP & São Carlos & $13560-000$ & $13577-999$ \\
\hline SP & São José do Rio Preto & $15000-000$ & $15100-999$ \\
\hline & & & \\
\hline & & & \\
\hline
\end{tabular}

\begin{tabular}{|l|c|c|c|}
\hline SP & São José dos Campos & $12200-000$ & $12248-999$ \\
\hline SP & São Roque & $18130-000$ & $18139-999$ \\
\hline SP & Sorocaba & $18000-000$ & $18109-999$ \\
\hline SP & Sumaré & $13170-000$ & $13182-999$ \\
\hline SP & Taubaté & $12000-000$ & $12119-999$ \\
\hline SP & Valinhos & $13270-000$ & $13279-999$ \\
\hline SP & Vinhedo & $13280-000$ & $13289-999$ \\
\hline SP & Barueri & $06400-000$ & $06499-999$ \\
\hline SP & Cajamar & $07750-000$ & $07799-999$ \\
\hline SP & Carapicuíba & $06300-000$ & $06399-999$ \\
\hline SP & Cotia & $06700-000$ & $06729-999$ \\
\hline SP & Diadema & $09900-000$ & $09999-999$ \\
\hline SP & Guarujá & $11400-000$ & $11499-999$ \\
\hline SP & Guarulhos & $07000-000$ & $07399-999$ \\
\hline SP & Itapecerica da Serra & $06850-000$ & $06889-999$ \\
\hline SP & Itapevi & $06650-000$ & $06699-999$ \\
\hline SP & Itaquaquecetuba & $08570-000$ & $08599-999$ \\
\hline SP & Mauá & $09300-000$ & $09399-999$ \\
\hline SP & Moji das Cruzes & $08700-000$ & $08899-999$ \\
\hline SP & Praia Grande & $11700-000$ & $11729-999$ \\
\hline SP & Osasco & $06000-000$ & $06299-999$ \\
\hline SP & Santo André & $09000-000$ & $09299-999$ \\
\hline SP & Santos & $11000-000$ & $11096-999$ \\
\hline SP & São Bernardo do Campo & $09600-000$ & $09899-999$ \\
\hline SP & São Caetano do Sul & $09500-000$ & $09599-999$ \\
\hline SP & & $01000-000$ & $05999-999$ \\
\hline SP & São Paulo & $08000-000$ & $08499-999$ \\
\hline SP & São Vicente & $11300-000$ & $11399-999$ \\
\hline SP & Suzano & $08600-000$ & $08699-999$ \\
\hline SP & Taboão da Serra & $06750-000$ & $06799-999$ \\
\hline TO & & $77000-000$ & $77249-999$ \\
\hline
\end{tabular}

Fonte: DIOPE/Correios. 


\section{ANEXO C. Cidades com prazo de entrega dos Correios de 7 a 15 dias úteis no Brasil}

Cidades G - 7 dias úteis

\begin{tabular}{|c|c|c|c|}
\hline UF & CIDADE & $\begin{array}{c}\text { CEP } \\
\text { INICIAL }\end{array}$ & CEP FINAL \\
\hline AM & ALVARAES & $69475-000$ & $69479-999$ \\
\hline AM & UARINI & $69485-000$ & $69489-999$ \\
\hline BA & FEIRA DA MATA & $46446-000$ & $46449-999$ \\
\hline MA & BOM LUGAR & $65704-000$ & $65704-999$ \\
\hline MA & MARAJA DO SENA & $65714-000$ & $65714-999$ \\
\hline MT & CURVELANDIA & $78237-000$ & $78239-999$ \\
\hline MT & LUCIARA & $78660-000$ & $78662-999$ \\
\hline MT & SANTA TEREZINHA & $78650-000$ & $78651-999$ \\
\hline MT & SAO JOSE DO XINGU & $78663-000$ & $78663-999$ \\
\hline PA & AVEIRO & $68150-000$ & $68164-999$ \\
\hline PA & CURRALINHO & $68815-000$ & $68819-999$ \\
\hline PA & JACAREACANGA & $68195-000$ & $68197-999$ \\
\hline PA & JURUTI & $68170-000$ & $68179-999$ \\
\hline PA & OBIDOS & $68250-000$ & $68269-999$ \\
\hline PA & PACAJA & $68485-000$ & $68487-999$ \\
\hline PA & PONTA DE PEDRAS & $68830-000$ & $68839-999$ \\
\hline PA & PRAINHA & $68130-000$ & $68137-999$ \\
\hline PB & TENORIO & $58665-000$ & $58519-999$ \\
\hline PB & VIEIROPOLIS & $58822-000$ & $58822-999$ \\
\hline PB & ZABELE & $58515-000$ & $58515-970$ \\
\hline PI & CALDEIRAO GRANDE & $64695-000$ & $64699-999$ \\
\hline PI & FARTURA DO PIAUI & $64788-000$ & $64789-999$ \\
\hline PI & FLORESTA DO PIAUI & $64563-000$ & $64564-999$ \\
\hline PI & JOAO COSTA & $64765-000$ & $64766-999$ \\
\hline PI & MORRO CABECA NO & $64968-000$ & $64969-999$ \\
\hline PI & RIBEIRA DO PIAUI & $64725-000$ & $64727-999$ \\
\hline PI & SAO BRAZ DO PIAUI & $64783-000$ & $64784-999$ \\
\hline RR & UIRAMUTA & $69358-000$ & $69359-999$ \\
\hline SC & SANTIAGO DO SUL & $89854-000$ & $89854-999$ \\
\hline
\end{tabular}

Cidades $\mathbf{H}$ - 8 dias úteis

\begin{tabular}{|c|c|c|c|}
\hline UF & CIDADE & $\begin{array}{c}\text { CEP } \\
\text { INICIAL }\end{array}$ & CEP FINAL \\
\hline AM & BARCELOS & $69700-000$ & $69729-999$ \\
\hline AM & IPIXUNA & $69890-000$ & $69894-999$ \\
\hline MT & $\begin{array}{c}\text { BOM JESUS DO } \\
\text { ARAGUAIA }\end{array}$ & $78678-000$ & $78679-999$ \\
\hline MT & IPIRANGA DO NORTE & $78578-000$ & $78578-999$ \\
\hline MT & ITANHANGA & $78579-000$ & $78579-999$ \\
\hline MT & $\begin{array}{c}\text { NOVO SANTO } \\
\text { ANTONIO }\end{array}$ & $78674-000$ & $78674-999$ \\
\hline MT & $\begin{array}{c}\text { SANTA CRUZ DO } \\
\text { XINGU }\end{array}$ & $78664-000$ & $78664-999$ \\
\hline MT & $\begin{array}{c}\text { SERRA NOVA } \\
\text { DOURADA }\end{array}$ & $78668-000$ & $78669-999$ \\
\hline PA & ALMEIRIM & $68230-000$ & $68249-999$ \\
\hline PA & BAGRE & $68475-000$ & $68479-999$ \\
\hline PA & BANNACH & $68388-000$ & $68389-999$ \\
\hline PA & MELGACO & $68490-000$ & $68499-999$ \\
\hline PA & MUANA & $68825-000$ & $68829-999$ \\
\hline
\end{tabular}

\begin{tabular}{|c|c|c|c|}
\hline PA & PORTEL & $68480-000$ & $68484-999$ \\
\hline PA & $\begin{array}{c}\text { SAO SEBASTIAO DA } \\
\text { BOA VISTA }\end{array}$ & $68820-000$ & $68824-999$ \\
\hline PA & TERRA SANTA & $68285-000$ & $68299-999$ \\
\hline PB & CASSERENGUE & $58238-000$ & $58239-999$ \\
\hline PB & DAMIAO & $58173-000$ & $58174-999$ \\
\hline AM & APUI & $69265-000$ & $69279-999$ \\
\hline AM & JAPURA & $69495-000$ & $69499-999$ \\
\hline AM & JURUA & $69520-000$ & $69599-999$ \\
\hline AM & MARAA & $69490-000$ & $69494-999$ \\
\hline AP & VITORIA DO JARI & $68924-000$ & $68924-999$ \\
\hline PA & ANAJAS & $68810-000$ & $68814-999$ \\
\hline PA & BAIAO & $68465-000$ & $68469-999$ \\
\hline PA & CACHOEIRA DO & $68840-000$ & $68849-999$ \\
\hline PA & ARARI & $68210-000$ & $68219-999$ \\
\hline PA & FARUA & $68280-000$ & $68284-999$ \\
\hline PA & GURUPA & $68300-000$ & $68329-999$ \\
\hline PA & LIMOEIRO DO AJURU & $68415-000$ & $68419-999$ \\
\hline PA & OEIRAS DO PARA & $68470-000$ & $68472-999$ \\
\hline PA & PLACAS & $68138-000$ & $68139-999$ \\
\hline PA & PORTO DE MOZ & $68330-000$ & $68359-999$ \\
\hline PA & $\begin{array}{c}\text { SANTA CRUZ DO } \\
\text { ARARI }\end{array}$ & $68850-000$ & $68859-999$ \\
\hline PA & SAO JOAO DA PONTA & $68774-000$ & $68774-999$ \\
\hline PA & $\begin{array}{c}\text { SENADOR JOSE } \\
\text { PORFIRIO }\end{array}$ & $68360-000$ & $68364-999$ \\
\hline PA & TRAIRAO & $68198-000$ & $68199-999$ \\
\hline TO & CHAPADA DE AREIA & $77575-000$ & $77579-999$ \\
\hline & & & \\
\hline
\end{tabular}

Cidades I - 9 dias úteis

\begin{tabular}{|c|c|c|c|}
\hline UF & CIDADE & $\begin{array}{c}\text { CEP } \\
\text { INICIAL }\end{array}$ & CEP FINAI \\
\hline $\mathrm{AM}$ & APUI & 69265-000 & $69279-999$ \\
\hline $\mathrm{AM}$ & JAPURA & $69495-000$ & 69499-999 \\
\hline $\mathrm{AM}$ & JURUA & $69520-000$ & 69599-999 \\
\hline $\mathrm{AM}$ & MARAA & $69490-000$ & 69494-999 \\
\hline $\mathrm{AP}$ & VITORIA DO JARI & $68924-000$ & 68924-999 \\
\hline PA & ANAJAS & $68810-000$ & 68814-999 \\
\hline PA & BAIAO & $68465-000$ & 68469-999 \\
\hline PA & $\begin{array}{c}\text { CACHOEIRA DO } \\
\text { ARARI }\end{array}$ & $68840-000$ & 68849-999 \\
\hline PA & CURUA & $68210-000$ & 68219-999 \\
\hline PA & FARO & $68280-000$ & 68284-999 \\
\hline PA & GURUPA & $68300-000$ & 68329-999 \\
\hline PA & LIMOEIRO DO AJURU & $68415-000$ & 68419-999 \\
\hline PA & OEIRAS DO PARA & 68470-000 & $68472-999$ \\
\hline PA & PLACAS & $68138-000$ & 68139-999 \\
\hline $\mathrm{PA}$ & PORTO DE MOZ & 68330-000 & 68359-999 \\
\hline PA & $\begin{array}{c}\text { SANTA CRUZ DO } \\
\text { ARARI } \\
\end{array}$ & $68850-000$ & $68859-999$ \\
\hline PA & SAO JOAO DA PONTA & 68774-000 & 68774-999 \\
\hline PA & $\begin{array}{c}\begin{array}{l}\text { SENADOR JOSE } \\
\text { PORFIRIO }\end{array} \\
\end{array}$ & $68360-000$ & 68364-999 \\
\hline PA & TRAIRAO & 68198-000 & $68199-999$ \\
\hline
\end{tabular}




\begin{tabular}{|l|l|l|l|}
\hline TO & CHAPADA DE AREIA & $77575-000$ & $77579-999$ \\
\hline
\end{tabular}

Cidades $\mathbf{J}$ - 10 dias úteis

\begin{tabular}{|c|c|c|c|}
\hline UF & CIDADE & $\begin{array}{c}\text { CEP } \\
\text { INICIAL }\end{array}$ & CEP FINAL \\
\hline AM & BOCA DO ACRE & $69850-000$ & $69859-999$ \\
\hline AM & JUTAI & $69660-000$ & $69669-999$ \\
\hline PA & ANAPU & $68365-000$ & $68369-999$ \\
\hline PA & PICARRA & $68575-000$ & $68579-999$ \\
\hline TO & LIZARDA & $77630-000$ & $77634-999$ \\
\hline TO & MATEIROS & $77593-000$ & $77599-999$ \\
\hline TO & $\begin{array}{c}\text { SAO FELIX DO } \\
\text { TOCANTINS }\end{array}$ & $77605-000$ & $77609-999$ \\
\hline
\end{tabular}

Cidades $\mathrm{K}$ - 11 dias úteis

\begin{tabular}{|c|c|c|c|}
\hline UF & CIDADE & CEP & INICIAL \\
CEP FINAL \\
\hline AM & ATALAIA DO NORTE & $69650-000$ & $69659-999$ \\
\hline AM & ITAMARATI & $69510-000$ & $69519-999$ \\
\hline AM & PAUINI & $69860-000$ & $69869-999$ \\
\hline TO & RECURSOLANDIA & $77733-000$ & $77734-999$ \\
\hline
\end{tabular}

Cidades $\mathrm{L}-12$ dias úteis

\begin{tabular}{|c|c|c|c|}
\hline UF & CIDADE & $\begin{array}{c}\text { CEP } \\
\text { INICIAL }\end{array}$ & CEP FINAL \\
\hline AM & AMATURA & $69620-000$ & $69629-999$ \\
\hline AM & $\begin{array}{c}\text { SANTA ISABEL DO } \\
\text { RIO NEGRO }\end{array}$ & $69740-000$ & $69749-999$ \\
\hline AM & $\begin{array}{c}\text { SANTO ANTONIO DO } \\
\text { ICA }\end{array}$ & $69680-000$ & $69684-999$ \\
\hline AM & TAPAUA & $69480-000$ & $69484-999$ \\
\hline AM & TONANTINS & $69685-000$ & $69699-999$ \\
\hline
\end{tabular}

\section{Cidades M - Não há}

Cidades N - 14 dias úteis

\begin{tabular}{|c|c|c|c|}
\hline UF & CIDADE & $\begin{array}{c}\text { CEP } \\
\text { INICIAL }\end{array}$ & CEP FINAL \\
\hline $\mathrm{AC}$ & MANOEL URBANO & $69950-000$ & 69954-999 \\
\hline $\mathrm{PA}$ & AFUA & $68890-000$ & $68899-999$ \\
\hline PA & CHAVES & 68880-000 & 68889-999 \\
\hline
\end{tabular}

Cidades O - 15 dias úteis

\begin{tabular}{|c|c|c|c|}
\hline UF & CIDADE & $\begin{array}{c}\text { CEP } \\
\text { INICIAL }\end{array}$ & CEP FINAL \\
\hline AC & JORDAO & $69975-000$ & $69979-999$ \\
\hline AC & $\begin{array}{c}\text { MARECHAL } \\
\text { THAUMATURGO }\end{array}$ & $69983-000$ & $69984-999$ \\
\hline AC & PORTO WALTER & $69982-000$ & $69982-999$ \\
\hline AC & $\begin{array}{c}\text { SANTA ROSA DO } \\
\text { PURUS }\end{array}$ & $69955-000$ & $69959-999$ \\
\hline AM & ENVIRA & $69870-000$ & $69879-999$ \\
\hline RO & Pedras Negras & $76936-000$ & $76936-999$ \\
\hline
\end{tabular}

Fonte: DIOPE/Correios. 


\section{ANEXO D. Destinos oferecidos pelo serviço SEDEX 10 no Rio Grande do Norte}

\begin{tabular}{|c|c|c|c|c|c|}
\hline \multicolumn{3}{|c|}{ ORIGEM } & \multicolumn{3}{|c|}{ DESTINO } \\
\hline \multicolumn{2}{|c|}{$\begin{array}{l}\text { FAIXA DE CEP DE } \\
\text { POSTAGEM }\end{array}$} & \multirow{2}{*}{$\begin{array}{l}\text { LOCALIDADE } \\
\text { CearáMirim }\end{array}$} & \multicolumn{2}{|c|}{$\begin{array}{l}\text { FAIXA DE CEP DE } \\
\text { ENTREGA }\end{array}$} & \multirow[t]{2}{*}{ LOCALIDADE } \\
\hline $59570-000$ & $59570-999$ & & $59000-000$ & $59139-999$ & \\
\hline $59575-000$ & $59575-999$ & Extremoz & 01000-000 & 04871-999 & São Paulo \\
\hline $59280-000$ & 59280-999 & Macaíba & 04873-000 & $04874-999$ & São Paulo \\
\hline $59000-000$ & 59139-999 & Natal & 04876-000 & 05999-999 & São Paulo \\
\hline 59140-000 & $59161-999$ & Parnamirim & 06000-000 & 06299-999 & Osasco \\
\hline \multirow[t]{42}{*}{$59290-000$} & $59290-999$ & São Gonçalo do Amarante & $06300-000$ & 06399-999 & Carapicuíba \\
\hline & & & 06400-000 & 06499-999 & Barueri \\
\hline & & & 06800-000 & 06849-999 & Embu \\
\hline & & & 07000-000 & 07399-999 & Guarulhos \\
\hline & & & $08000-000$ & 08499-999 & São Paulo \\
\hline & & & 08570-000 & 08599-999 & Itaquaquecetuba \\
\hline & & & 08600-000 & 08699-999 & Suzano \\
\hline & & & 08700-000 & 08899-999 & Mogi das Cruzes \\
\hline & & & 09000-000 & 09299-999 & Santo André \\
\hline & & & $09300-000$ & 09399-999 & Mauá \\
\hline & & & 09500-000 & 09599-999 & São Caetano do Sul \\
\hline & & & 09600-000 & 09899-999 & São Bernardo do Campo \\
\hline & & & 09900-000 & 09999-999 & Diadema \\
\hline & & & $11000-000$ & $11096-999$ & Santos \\
\hline & & & $11300-000$ & $11399-999$ & São Vicente \\
\hline & & & $11400-000$ & $11499-999$ & Guarujá \\
\hline & & & $12000-000$ & $12119-999$ & Taubaté \\
\hline & & & $12200-000$ & $12248-999$ & São José dos Campos \\
\hline & & & $13000-000$ & 13139-999 & Campinas \\
\hline & & & $13140-000$ & $13149-999$ & Paulinea \\
\hline & & & $13170-000$ & $13182-999$ & Sumaré \\
\hline & & & $13200-000$ & $13219-999$ & Jundiaí \\
\hline & & & $13400-000$ & $13439-999$ & Piracicaba \\
\hline & & & $13480-000$ & 13489-999 & Limeira \\
\hline & & & $13560-000$ & $13577-999$ & São Carlos \\
\hline & & & $13820-000$ & $13824-999$ & Jaguariúna \\
\hline & & & $14000-000$ & 14109-999 & Ribeirão Preto \\
\hline & & & $17000-000$ & $17109-999$ & Bauru \\
\hline & & & $18000-000$ & 18109-999 & Sorocaba \\
\hline & & & $20000-000$ & $20395-999$ & Rio de Janeiro \\
\hline & & & 20398-000 & 23799-999 & Rio de Janeiro \\
\hline & & & $24000-000$ & 24399-999 & Niterói \\
\hline & & & $24400-000$ & 24799-999 & São Gonçalo \\
\hline & & & $25000-000$ & $25499-999$ & Duque de Caxias \\
\hline & & & $25500-000$ & $25599-999$ & São João de Meriti \\
\hline & & & $25900-000$ & 25939-999 & Magé \\
\hline & & & $26000-000$ & 26099-999 & Nova Iguaçu \\
\hline & & & $26100-000$ & $26199-999$ & Belford Roxo \\
\hline & & & $26200-000$ & $26299-999$ & Nova Iguaçu \\
\hline & & & $26500-000$ & $26549-999$ & Nilópolis \\
\hline & & & $26550-000$ & 26599-999 & Mesquita \\
\hline & & & $29000-000$ & 29099-999 & Vitória \\
\hline
\end{tabular}




\begin{tabular}{|c|c|c|c|c|c|}
\hline & & & $30000-000$ & $31999-999$ & Belo Horizonte \\
\hline & & & $32000-000$ & 32399-999 & Contagem \\
\hline & & & $32600-000$ & $32600-999$ & Betim \\
\hline & & & $32649-000$ & $32667-999$ & Betim \\
\hline & & & $36000-000$ & 36099-999 & Juiz de Fora \\
\hline & & & $38000-000$ & 38099-999 & Uberaba \\
\hline & & & $40000-000$ & 42499-999 & Salvador \\
\hline & & & $70000-000$ & 70999-999 & Brasília \\
\hline & & & $71000-000$ & 71399-999 & Guará \\
\hline & & & $71500-000$ & 71569-999 & Brasília \\
\hline & & & $71600-000$ & 71689-999 & Brasília \\
\hline & & & $71900-000$ & 72199-999 & Taguatinga \\
\hline & & & $79000-000$ & 79124-999 & Campo Grande \\
\hline & & & $80000-000$ & 82999-999 & Curitiba \\
\hline & & & $83000-000$ & $83149-999$ & São José dos Pinhais \\
\hline & & & $90000-000$ & 91999-999 & Porto Alegre \\
\hline & & & $92000-000$ & $92449-999$ & Canoas \\
\hline & & & $93300-000$ & 93599-999 & Novo Hamburgo \\
\hline & & & $94000-000$ & 94329-999 & Gravataí \\
\hline & & & $94400-000$ & 94729-999 & Viamão \\
\hline 59370-000 & $59370-999$ & Acari & $59000-000$ & 59139-999 & Natal \\
\hline $59650-000$ & $59650-999$ & Açu & & & \\
\hline $59510-000$ & $59510-999$ & Afonso Bezerra & & & \\
\hline 59965-000 & 59965-999 & Alexandria & & & \\
\hline $59760-000$ & $59760-999$ & Almino Afonso & & & \\
\hline $59507-000$ & $59507-999$ & Alto do Rodrigues & & & \\
\hline 59515-000 & $59515-999$ & Angicos & & & \\
\hline $59870-000$ & $59870-999$ & Antonio Martins & & & \\
\hline 59700-000 & $59700-999$ & Apodi & & & \\
\hline 59655-000 & $59655-999$ & Areia Branca & & & \\
\hline 59170-000 & $59170-999$ & Ares & & & \\
\hline 59194-000 & 59194-999 & Baia Formosa & & & \\
\hline 59695-000 & $59695-999$ & Barauna & & & \\
\hline $59410-000$ & $59410-999$ & Barcelona & & & \\
\hline $59270-000$ & $59270-999$ & Bom Jesus & & & \\
\hline 59219-000 & $59219-999$ & Brejinho & & & \\
\hline $59540-000$ & $59540-999$ & Caiçara do Rio do Vento & & & \\
\hline $59300-000$ & $59300-999$ & Caico & & & \\
\hline $59230-000$ & 59230-999 & Campo Redondo & & & \\
\hline $59190-000$ & $59190-999$ & Canguaretama & & & \\
\hline $59780-000$ & $59780-999$ & Caraubas & & & \\
\hline $59374-000$ & $59374-999$ & Carnauba dos Dantas & & & \\
\hline $59380-000$ & 59380-999 & Currais Novos & & & \\
\hline 59180-000 & $59180-999$ & Espirito Santo & & & \\
\hline $59517-000$ & $59517-999$ & Fernando Pedroza & & & \\
\hline $59890-000$ & $59890-999$ & Frutuoso Gomes & & & \\
\hline 59173-000 & 59173-999 & Goianinha & & & \\
\hline $59790-000$ & $59790-999$ & Governador DixSept Rosado & & & \\
\hline $59675-000$ & $59675-999$ & Grossos & & & \\
\hline $59508-000$ & 59508-999 & Ipanguaçu & & & \\
\hline $59855-000$ & $59855-999$ & Itau & & & \\
\hline $59594-000$ & $59594-999$ & Jandaira & & & \\
\hline
\end{tabular}




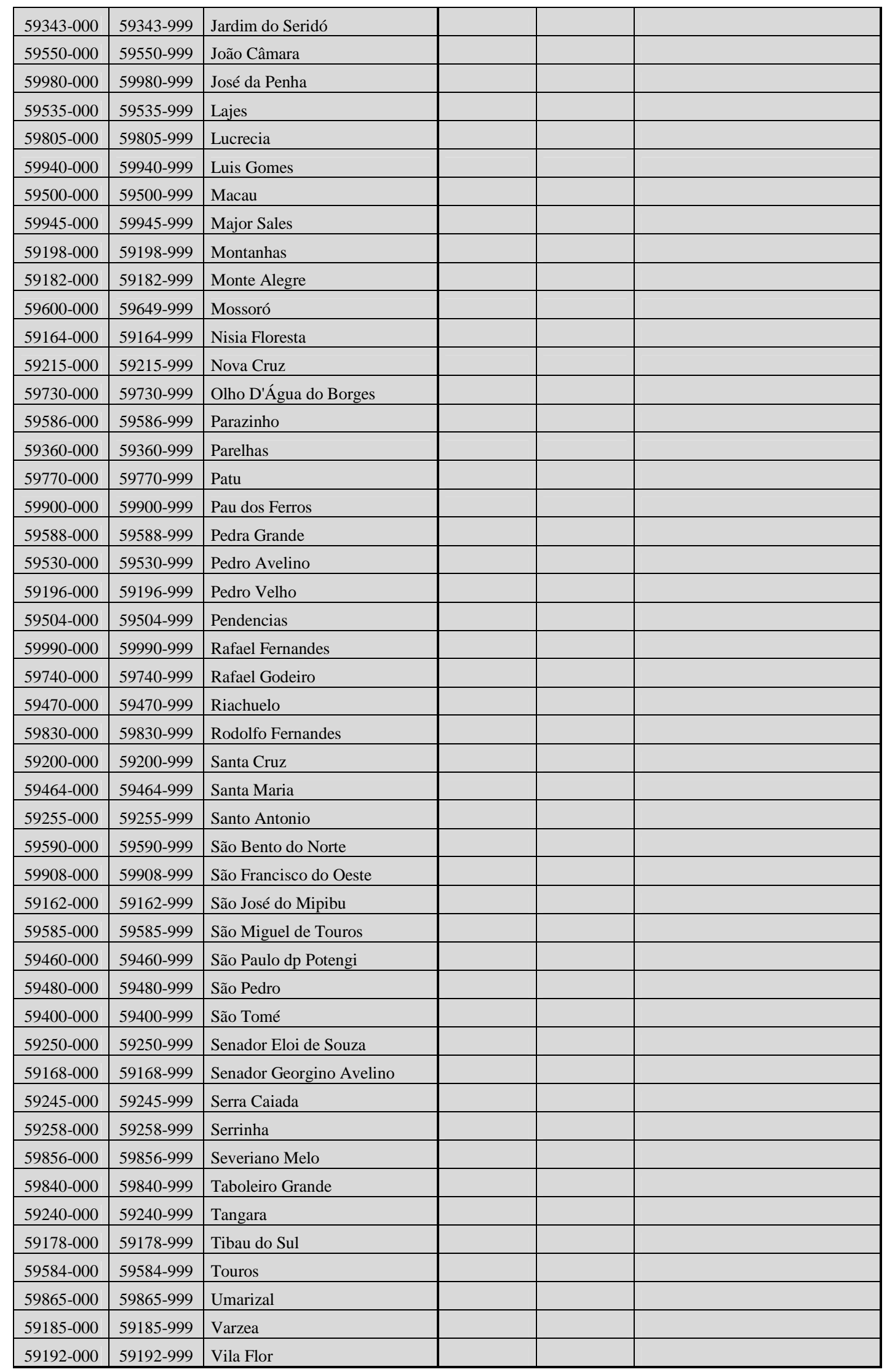

Fonte: DIOPE/Correios. 


\section{ANEXO E. Destinos oferecidos pelo serviço SEDEX 10 em Santa Catarina}

\begin{tabular}{|c|c|c|c|c|c|}
\hline \multicolumn{3}{|c|}{ ORIGEM } & \multicolumn{3}{|c|}{ DESTINO } \\
\hline \multicolumn{2}{|c|}{$\begin{array}{l}\text { FAIXA DE CEP DE } \\
\text { POSTAGEM }\end{array}$} & \multirow{2}{*}{\begin{tabular}{|l} 
LOCALIDADE \\
Chapecó \\
\end{tabular}} & \multicolumn{2}{|c|}{$\begin{array}{c}\text { FAIXA DE CEP DE } \\
\text { ENTREGA }\end{array}$} & \multirow{2}{*}{$\begin{array}{l}\text { LOCALIDADE } \\
\text { Florianópolis } \\
\end{array}$} \\
\hline $89800-000$ & $89815-999$ & & $88000-000$ & 88099-999 & \\
\hline & & & $88100-000$ & 88123-999 & São José \\
\hline & & & $89000-000$ & 89099-999 & Blumenau \\
\hline & & & $89200-000$ & 89239-999 & Joinville \\
\hline & & & 90000-000 & 91999-999 & Porto Alegre \\
\hline & & & $92000-000$ & 92449-999 & Canoas \\
\hline & & & 93300-000 & 93599-999 & Novo Hamburgo \\
\hline & & & $94000-000$ & 94329-999 & Gravataí \\
\hline & & & 94400-000 & 94729-999 & Viamão \\
\hline & & & $95000-000$ & 95124-999 & Caxias do Sul \\
\hline & & & $96000-000$ & 96099-999 & Pelotas \\
\hline & & & $97000-000$ & 97119-999 & Santa Maria \\
\hline $88450-000$ & 88459-999 & Alfredo Wagner & 01000-000 & 04871-999 & São Paulo \\
\hline $88180-000$ & 88189-999 & Antônio Carlos & 04873-000 & 04874-999 & São Paulo \\
\hline $88900-000$ & 88913-999 & Araranguá & 04876-000 & 05999-999 & São Paulo \\
\hline $88330-000$ & 88339-999 & Balneário Camboriú & 06000-000 & 06299-999 & Osasco \\
\hline $88390-000$ & 88394-999 & Barra Velha & 06300-000 & 06399-999 & Carapicuíba \\
\hline $88160-000$ & 88179-999 & Biguaçu & 06400-000 & 06499-999 & Barueri \\
\hline $89000-000$ & $89099-999$ & Blumenau & 06800-000 & 06849-999 & Embu \\
\hline $88680-000$ & 88689-999 & Bom Retiro & 07000-000 & 07399-999 & Guarulhos \\
\hline $88215-000$ & 88219-999 & Bombinhas & 08000-000 & 08499-999 & São Paulo \\
\hline $88370-000$ & 88370-999 & Botuverá & 08570-000 & 08599-999 & Itaquaquecetuba \\
\hline $88350-000$ & 88359-999 & Brusque & 08600-000 & 08699-999 & Suzano \\
\hline $88340-000$ & 88349-999 & Camboriú & 08700-000 & 08899-999 & Mogi das Cruzes \\
\hline $88230-000$ & 88239-999 & Canelinha & 09000-000 & 09299-999 & Santo André \\
\hline $89460-000$ & $89477-999$ & Canoinhas & 09300-000 & 09399-999 & Mauá \\
\hline $88800-000$ & 88819-999 & Criciúma & 09500-000 & 09599-999 & São Caetano do Sul \\
\hline $88000-000$ & 88099-999 & Florianópolis & 09600-000 & 09899-999 & São Bernardo do Campo \\
\hline $88495-000$ & 88499-999 & Garopaba & 09900-000 & 09999-999 & Diadema \\
\hline $89110-000$ & 89114-999 & Gaspar & $11000-000$ & 11096-999 & Santos \\
\hline $88360-000$ & 88360-999 & Guabiruba & $11300-000$ & 11399-999 & São Vicente \\
\hline $88820-000$ & 88829-999 & Içara & $11400-000$ & $11499-999$ & Guarujá \\
\hline $88780-000$ & 88789-999 & Imbituva & $12000-000$ & 12119-999 & Taubaté \\
\hline $89340-000$ & 89349-999 & Itaiópolis & $12200-000$ & $12248-999$ & São José dos Campos \\
\hline $88300-000$ & 88319-999 & Itajaí & $13000-000$ & $13139-999$ & Campinas \\
\hline $88220-000$ & 88229-999 & Itapema & $13140-000$ & $13149-999$ & Paulinea \\
\hline $89250-000$ & $89269-999$ & Jaraguá do Sul & $13170-000$ & 13182-999 & Sumaré \\
\hline $89200-000$ & 89239-999 & Joinville & $13200-000$ & $13219-999$ & Jundiaí \\
\hline $88500-000$ & 88529-999 & Lages & $13400-000$ & $13439-999$ & Piracicaba \\
\hline $88790-000$ & 88799-999 & Laguna & $13480-000$ & 13489-999 & Limeira \\
\hline $89300-000$ & 89339-999 & Mafra & $13560-000$ & $13577-999$ & São Carlos \\
\hline 89480-000 & 89489-999 & Major Vieira & $13820-000$ & $13824-999$ & Jaguariúna \\
\hline $89108-000$ & 89109-999 & Massaranduba & $14000-000$ & 14109-999 & Ribeirão Preto \\
\hline $89380-000$ & 89380-999 & Monte Castelo & $17000-000$ & 17109-999 & Bauru \\
\hline $88375-000$ & 88379-999 & Navegantes & $18000-000$ & $18109-999$ & Sorocaba \\
\hline $88270-000$ & 88279-999 & Nova Trento & $20000-000$ & 20395-999 & Rio de Janeiro \\
\hline $88540-000$ & 88542-999 & Otacílio Costa & 20398-000 & 23799-999 & Rio de Janeiro \\
\hline
\end{tabular}




\begin{tabular}{|c|c|c|c|c|c|}
\hline $88130-000$ & $88138-999$ & Palhoça & $24000-000$ & 24399-999 & Niterói \\
\hline $89370-000$ & 89379-999 & Papanduva & $24400-000$ & 24799-999 & São Gonçalo \\
\hline $88385-000$ & 88389-999 & Penha & $25000-000$ & 25499-999 & Duque de Caxias \\
\hline $88380-000$ & $88384-999$ & Piçarras & $25500-000$ & 25599-999 & São João de Meriti \\
\hline $89107-000$ & $89107-999$ & Pomerode & $25900-000$ & 25939-999 & Magé \\
\hline $88210-000$ & $88214-999$ & Porto Belo & $26000-000$ & 26099-999 & Nova Iguaçu \\
\hline $88140-000$ & 88149-999 & Santo Amaro da Imperatriz & $26100-000$ & 26199-999 & Belford Roxo \\
\hline $89240-000$ & $89244-999$ & São Francisco do Sul & $26200-000$ & $26299-999$ & Nova Iguaçu \\
\hline $88240-000$ & $88249-999$ & São João Batista & $26500-000$ & 26549-999 & Nilópolis \\
\hline $88100-000$ & $88123-999$ & São José & $26550-000$ & $26599-999$ & Mesquita \\
\hline $88200-000$ & $88209-999$ & Tijucas & $29000-000$ & 29099-999 & Vitória \\
\hline \multirow[t]{22}{*}{$88700-000$} & 88709-999 & Tubarão & $30000-000$ & 31999-999 & Belo Horizonte \\
\hline & & & $32000-000$ & 32399-999 & Contagem \\
\hline & & & $32600-000$ & $32600-999$ & Betim \\
\hline & & & $32649-000$ & $32667-999$ & Betim \\
\hline & & & $36000-000$ & 36099-999 & Juiz de Fora \\
\hline & & & $40000-000$ & 42499-999 & Salvador \\
\hline & & & $70000-000$ & 70999-999 & Brasília \\
\hline & & & $71000-000$ & 71399-999 & Guará \\
\hline & & & $71500-000$ & 71569-999 & Brasília \\
\hline & & & $71600-000$ & $71689-999$ & Brasília \\
\hline & & & $71900-000$ & $72199-999$ & Taguatinga \\
\hline & & & $80000-000$ & $82999-999$ & Curitiba \\
\hline & & & $83000-000$ & $83149-999$ & São José dos Pinhais \\
\hline & & & $88000-000$ & 88099-999 & Florianópolis \\
\hline & & & $88100-000$ & 88123-999 & São José \\
\hline & & & $89000-000$ & 89099-999 & Blumenau \\
\hline & & & $89200-000$ & 89239-999 & Joinville \\
\hline & & & $90000-000$ & 91999-999 & Porto Alegre \\
\hline & & & $92000-000$ & 92449-999 & Canoas \\
\hline & & & $93300-000$ & 93599-999 & Novo Hamburgo \\
\hline & & & $94000-000$ & 94329-999 & Gravataí \\
\hline & & & $94400-000$ & 94729-999 & Viamão \\
\hline $89700-000$ & $89729-999$ & Concórdia & $88000-000$ & 88099-999 & Florianópolis \\
\hline $89610-000$ & $89612-999$ & Herval D'Oeste & $88100-000$ & 88123-999 & São José \\
\hline $89600-000$ & $89608-999$ & Joacaba & $89000-000$ & 89099-999 & Blumenau \\
\hline \multirow[t]{9}{*}{ 89609-000 } & 89609-999 & Luzerna & $89200-000$ & 89239-999 & Joinville \\
\hline & & & $90000-000$ & 91999-999 & Porto Alegre \\
\hline & & & $92000-000$ & 92449-999 & Canoas \\
\hline & & & $93300-000$ & 93599-999 & Novo Hamburgo \\
\hline & & & $94000-000$ & 94329-999 & Gravataí \\
\hline & & & $94400-000$ & 94729-999 & Viamão \\
\hline & & & $95000-000$ & 95124-999 & Caxias do Sul \\
\hline & & & $96000-000$ & $96099-999$ & Pelotas \\
\hline & & & $97000-000$ & 97119-999 & Santa Maria \\
\hline $88740-000$ & 88740999 & Armazém & $88000-000$ & $88099-999$ & Florianópolis \\
\hline $88750-000$ & 88759-999 & Braço do Norte & $88100-000$ & 88123-999 & São José \\
\hline $88845-000$ & 88849-999 & Cocal do Sul & $89000-000$ & 89099-999 & Blumenau \\
\hline 88850-000 & 88850-999 & Forquilhinha & $89200-000$ & 89239-999 & Joinville \\
\hline $88890-000$ & 88890-999 & Grão Pará & $90000-000$ & 91999-999 & Porto Alegre \\
\hline $88735-000$ & 88739-999 & Gravatal & $92000-000$ & 92449-999 & Canoas \\
\hline 88950-000 & $88954-999$ & Jacinto Machado & $93300-000$ & 93599-999 & Novo Hamburgo \\
\hline
\end{tabular}




\begin{tabular}{|c|c|c|c|c|c|}
\hline $88715-000$ & 88715-999 & Jaguaruna & 94000-000 & 94329-999 & Gravataí \\
\hline $88880-000$ & 88889-999 & Lauro Muller & 94400-000 & 94729-999 & Viamão \\
\hline $88915-000$ & $88915-999$ & Maracajá & & & \\
\hline $88920-000$ & 88924-999 & Meleiro & & & \\
\hline $88830-000$ & 88839-999 & Morro da Fumaça & & & \\
\hline $88865-000$ & 88865-999 & Nova Veneza & & & \\
\hline $88870-000$ & 88871-999 & Orleans & & & \\
\hline 88980-000 & 88980-999 & Passo de Torres & & & \\
\hline $88720-000$ & 88720-999 & Pedras Grandes & & & \\
\hline 88990-000 & 88990-999 & Praia Grande & & & \\
\hline $88760-000$ & 88760-999 & Rio Fortuna & & & \\
\hline $88717-000$ & $88717-999$ & Sangão & & & \\
\hline $88965-000$ & 88965-999 & Santa Rosa do Sul & & & \\
\hline 88970-000 & 88970-999 & São João do Sul & & & \\
\hline $88730-000$ & 88734-999 & São Ludgero & & & \\
\hline $88765-000$ & 88765-999 & São Martinho & & & \\
\hline $88860-000$ & 88860-999 & Siderópolis & & & \\
\hline $88960-000$ & 88963-999 & Sombrio & & & \\
\hline $88940-000$ & 88940-999 & Timbé do Sul & & & \\
\hline 88710-000 & 88710-999 & Treze de Maio & & & \\
\hline $88930-000$ & 88934-999 & Turvo & & & \\
\hline $88840-000$ & 88844-999 & Urussanga & & & \\
\hline $88420-000$ & 88429-999 & Agrolândia & $80000-000$ & 82999-999 & Curitiba \\
\hline 89188-000 & 89189-999 & Agronômica & $88000-000$ & $88099-999$ & Florianópolis \\
\hline $89135-000$ & 89135-999 & Apiúna & $88100-000$ & 88123-999 & São José \\
\hline $89245-000$ & 89246-999 & Araquari & 89000-000 & 89099-999 & Blumenau \\
\hline $89138-000$ & 89139-999 & Ascurra & 89200-000 & 89239-999 & Joinville \\
\hline $88410-000$ & 88419-999 & Atalanta & & & \\
\hline $89186-000$ & $89187-999$ & Aurora & & & \\
\hline $88380-000$ & 88384-999 & Balneário Piçarras & & & \\
\hline 89124-000 & 89125-999 & Benedito Novo & & & \\
\hline 89294-000 & 89294-999 & Campo Alegre & & & \\
\hline $89155-000$ & 89156-999 & Dona Emma & & & \\
\hline $89126-000$ & 89129-999 & Doutor Pedrinho & & & \\
\hline $89248-000$ & 89248-999 & Garuva & & & \\
\hline $89140-000$ & 89144-999 & Ibirama & & & \\
\hline $88320-000$ & 88329-999 & Ilhota & & & \\
\hline $88440-000$ & 88442-999 & Imbuia & & & \\
\hline $89130-000$ & 89134-999 & Indaial & & & \\
\hline 89440-000 & 89459-999 & Irineópolis & & & \\
\hline 89249-000 & 89249-999 & Itapoá & & & \\
\hline $88400-000$ & 88406-999 & Ituporanga & & & \\
\hline $89145-000$ & 89145-999 & José Boiteux & & & \\
\hline $89170-000$ & 89171-999 & Laurentino & & & \\
\hline $89182-000$ & 89183-999 & Lontras & & & \\
\hline $89115-000$ & 89119-999 & Luiz Alves & & & \\
\hline $88430-000$ & 88439-999 & Petrolândia & & & \\
\hline $89172-000$ & 89175-999 & Pouso Redondo & & & \\
\hline $89150-000$ & 89154-999 & Presidente Getúlio & & & \\
\hline $89184-000$ & 89185-999 & Presidente Nereu & & & \\
\hline 89198-000 & 89198-999 & Rio do Campo & & & \\
\hline $89180-000$ & 89181-999 & Rio do Oeste & & & \\
\hline
\end{tabular}




\begin{tabular}{|c|c|c|c|c|c|}
\hline $89160-000$ & 89169-999 & Rio do Sul & & & \\
\hline $89121-000$ & 89123-999 & Rio dos Cedros & & & \\
\hline 89136-000 & $89137-999$ & Rodeio & & & \\
\hline $89196-000$ & $89197-999$ & Salete & & & \\
\hline $89190-000$ & 89192-999 & Taió & & & \\
\hline $89120-000$ & $89120-999$ & Timbó & & & \\
\hline $89176-000$ & $89177-999$ & Trombudo Central & & & \\
\hline $88443-000$ & 88444-999 & Vidal Ramos & & & \\
\hline $89148-000$ & 89149-999 & Vitor Meireles & & & \\
\hline $89157-000$ & 89159-999 & Witmarsum & & & \\
\hline 89830-000 & 89830-999 & Abelardo Luz & $88000-000$ & 88099-999 & Florianópolis \\
\hline $89654-000$ & 89659-999 & Água Doce & $88100-000$ & 88123-999 & São José \\
\hline $89970-000$ & 89970-999 & Anchieta & $89000-000$ & $89099-999$ & Blumenau \\
\hline 89883-000 & 89883-999 & Águas de Chapecó & $89200-000$ & $89239-999$ & Joinville \\
\hline $88590-000$ & $88597-999$ & Anita Garibaldi & & & \\
\hline $89740-000$ & 89740-999 & Arabutã & & & \\
\hline $89590-000$ & 89590-999 & Arroio Trinta & & & \\
\hline $88538-000$ & 88539-999 & Bocaina do Sul & & & \\
\hline $89247-000$ & $89247-999$ & Balneário Barra do Sul & & & \\
\hline $88640-000$ & 88649-999 & Bom Jardim da Serra & & & \\
\hline $89873-000$ & 89873-999 & Bom Jesus do Oeste & & & \\
\hline $88370-000$ & 88374-999 & Botuverá & & & \\
\hline $89500-000$ & 89514-999 & Caçador & & & \\
\hline $89888-000$ & 89888-999 & Caibi & & & \\
\hline $88580-000$ & 88584-999 & Campo Belo do Sul & & & \\
\hline $89980-000$ & 89980-999 & Campo Erê & & & \\
\hline $89620-000$ & 89632-999 & Campos Novos & & & \\
\hline $89665-000$ & 89666-999 & Capinzal & & & \\
\hline $89670-000$ & 89674-999 & Catanduvas & & & \\
\hline $88598-000$ & 88599-999 & Celso Ramos & & & \\
\hline 89819-000 & 89819-999 & Cordilheira Alta & & & \\
\hline $89840-000$ & 89840-999 & Coronel Freitas & & & \\
\hline $88535-000$ & $88537-999$ & Correia Pinto & & & \\
\hline $89278-000$ & 89279-999 & Corupá & & & \\
\hline $89890-000$ & $89890-999$ & Cunha Pora & & & \\
\hline $89520-000$ & 89529-999 & Curitibanos & & & \\
\hline $89910-000$ & 89910-999 & Descanso & & & \\
\hline $89950-000$ & 89969-999 & Dionísio Cerqueira & & & \\
\hline $89613-000$ & $89617-999$ & Erval Velho & & & \\
\hline $89864-000$ & 89864-999 & Faxinal dos Guedes & & & \\
\hline $89580-000$ & 89589-999 & Fraiburgo & & & \\
\hline $89838-000$ & 89838-999 & Galvão & & & \\
\hline $88190-000$ & 88199-999 & Governador Celso ramos & & & \\
\hline $89920-000$ & 89922-999 & Guaraciaba & & & \\
\hline $89270-000$ & $89274-999$ & Guaramirim & & & \\
\hline $89940-000$ & 89940-999 & Guarujá do Sul & & & \\
\hline $89640-000$ & 89641-999 & Ibicaré & & & \\
\hline $89558-000$ & 89558-999 & Iomere & & & \\
\hline $89669-000$ & 89669-999 & Ipira & & & \\
\hline 89899-000 & 89899-999 & Iporá do Oeste & & & \\
\hline $89790-000$ & 89799-999 & Ipumirim & & & \\
\hline 89891-000 & 89891-999 & Iraceminha & & & \\
\hline
\end{tabular}




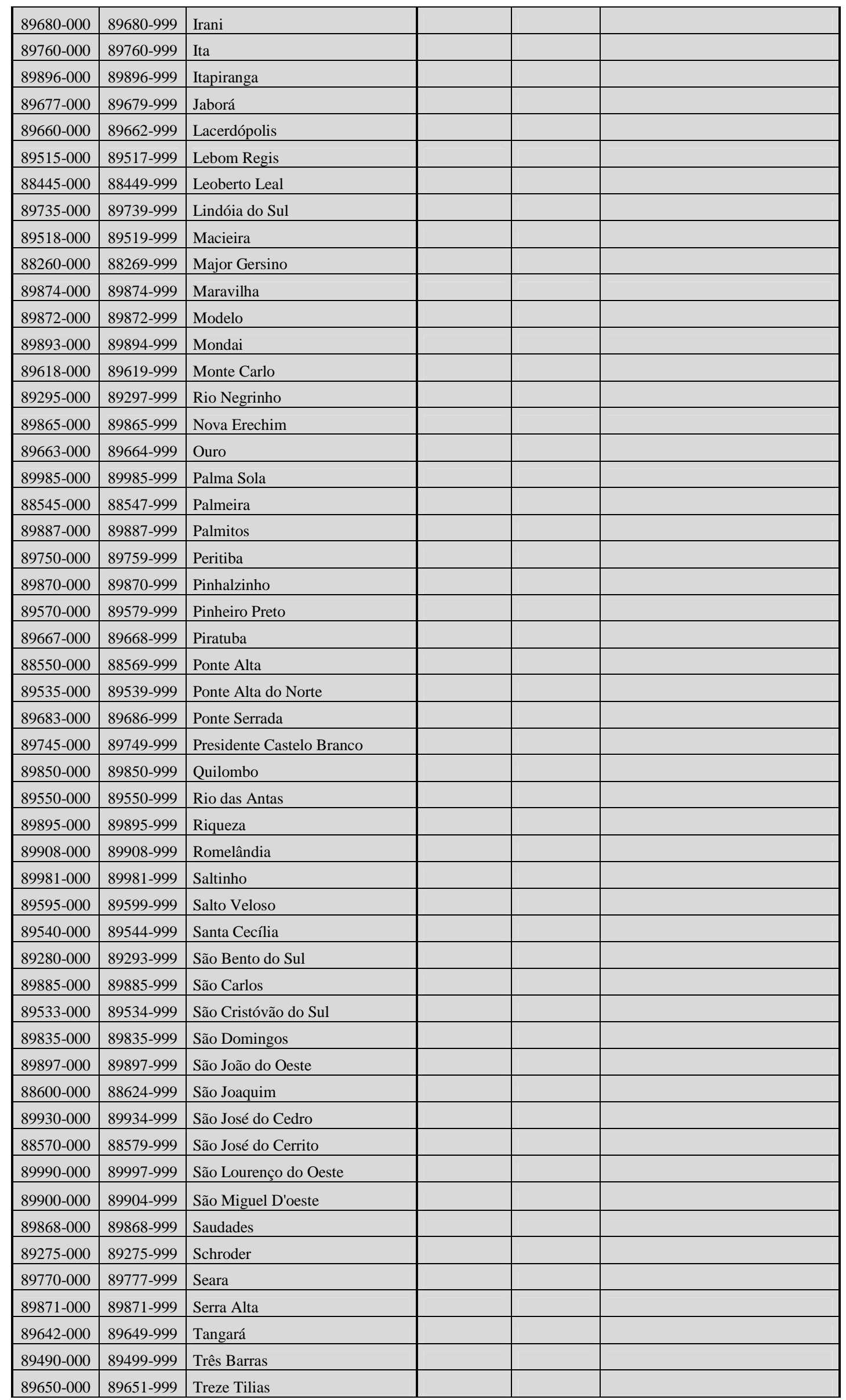




\begin{tabular}{|c|c|c|c|c|c|}
\hline $88650-000$ & $88657-999$ & Urubici & & & \\
\hline $88625-000$ & $88639-999$ & Urupema & & & \\
\hline $89690-000$ & $89690-999$ & Vargeão & & & \\
\hline $89560-000$ & $89569-999$ & Videira & & & \\
\hline $89820-000$ & $89823-999$ & Xanxerê & & & \\
\hline $89780-000$ & 89780-999 & Xavantina & & & \\
\hline $89825-000$ & $89827-999$ & Xaxim & & & \\
\hline \multirow[t]{8}{*}{$89400-000$} & $89409-999$ & Porto União & $80000-000$ & 82999-999 & Curitiba \\
\hline & & & $83000-000$ & 83149-999 & São José dos Pinhais \\
\hline & & & $84000-000$ & 84099-999 & Ponta Grossa \\
\hline & & & $86000-000$ & 86099-999 & Londrina \\
\hline & & & $88000-000$ & 88099-999 & Florianópolis \\
\hline & & & $88100-000$ & 88123-999 & São José \\
\hline & & & $89000-000$ & 89099-999 & Blumenau \\
\hline & & & $89200-000$ & 89239-999 & Joinville \\
\hline \multirow[t]{8}{*}{$88190-000$} & 88199-999 & Governador Celso Ramos & $80000-000$ & 82999-999 & Curitiba \\
\hline & & & $83000-000$ & 83149-999 & São José dos Pinhais \\
\hline & & & $86000-000$ & 86099-999 & Londrina \\
\hline & & & $88000-000$ & 88099-999 & Florianópolis \\
\hline & & & $88100-000$ & 88123-999 & São José \\
\hline & & & $89000-000$ & 89099-999 & Blumenau \\
\hline & & & $89200-000$ & 89239-999 & Joinville \\
\hline & & & $90000-000$ & 91999-999 & Porto Alegre \\
\hline $88475-000$ & 88475-999 & Anitapolis & $88000-000$ & 88099-999 & Florianópolis \\
\hline $88770-000$ & $88770-999$ & Imarui & $88100-000$ & 88123-999 & São José \\
\hline $88763-000$ & 88763-999 & Santa Rosa de Lima & $89000-000$ & 89099-999 & Blumenau \\
\hline 88485-000 & 88485-999 & São Bonifácio & $89200-000$ & 89239-999 & Joinville \\
\hline \multirow[t]{4}{*}{$88490-000$} & 88494-999 & Paulo Lopes & $90000-000$ & 91999-999 & Porto Alegre \\
\hline & & & $92000-000$ & 92449-999 & Canoas \\
\hline & & & $93300-000$ & 93599-999 & Novo Hamburgo \\
\hline & & & $94000-000$ & 94329-999 & Gravataí \\
\hline
\end{tabular}

Fonte: DIOPE/Correios. 